UNIVERSIDADE DE SÃO PAULO

IVAN KOWALESKI FIGUEIRA DE BARROS

ROMANTISMO E HISTÓRIA NAS PÁGINAS DE IL CONCILIATORE (SETEMBRO DE 1818 - OUTUBRO DE 1819): UMA INVESTIGAÇÃO SOBRE AS ORIGENS DO MOVIMENTO ROMÂNTICO NA ITÁLIA 
UNIVERSIDADE DE SÃO PAULO

IVAN KOWALESKI FIGUEIRA DE BARROS

\section{ROMANTISMO E HISTÓRIA NAS PÁGINAS DE IL CONCILIATORE (SETEMBRO DE 1818 - OUTUBRO DE 1819): UMA INVESTIGAÇÃO SOBRE AS ORIGENS DO MOVIMENTO ROMÂNTICO NA ITÁLIA}

Tese apresentada para obtenção do grau de doutor pela Universidade de São Paulo, na Faculdade de Filosofia, Letras e Ciências Humanas, no Programa de História Social do Departamento de História, sob a orientação da Prof. ${ }^{\text {a }}$ Dr. ${ }^{\text {a }}$ Sara Albieri.

São Paulo 
FOLHA DE APROVAÇÃO

Ivan Kowaleski Figueira de Barros

Romantismo e História nas páginas de I/ Conciliatore

(setembro de 1818 - outubro de 1819): uma investigação

sobre as origens do movimento romântico na Itália

Tese apresentada para obtenção do grau de doutor pela Universidade de São Paulo, na Faculdade de Filosofia,Letras e Ciências Humanas, no Programa de História Social do Departamento de História, sob a orientação da Prof. ${ }^{\text {a }}$ Dr. ${ }^{\text {a }}$ Sara Albieri.

São Paulo, 2017

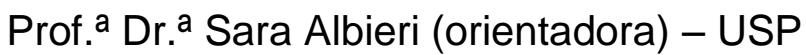

Prof. Dr.

Prof. Dr.

Prof. Dr.

Prof. Dr. 


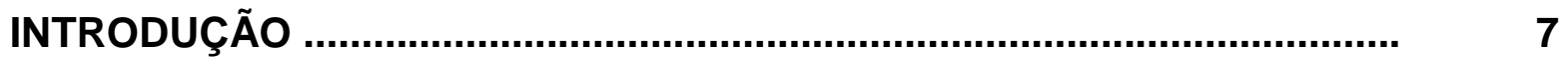

CAPÍTULO 1 - A ERA ROMÂNTICA: O CENÁRIO HISTÓRICO POLÍTICO 18

CAPÍTULO 2 - ROMANTISMO E CLASSICISMO_...................................... 34

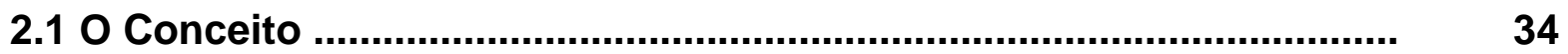

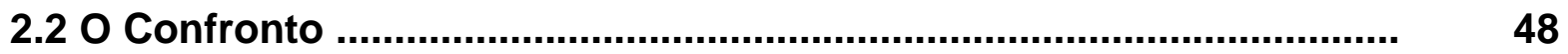

CAPÍTULO 3 - UM JORNAL ROMÂNTICO: IL CONCILIATORE ................ 71

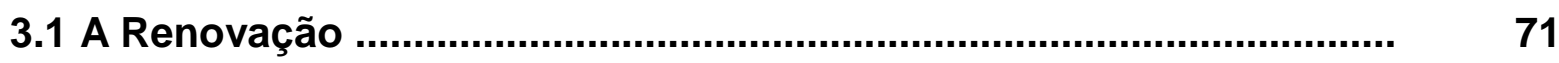

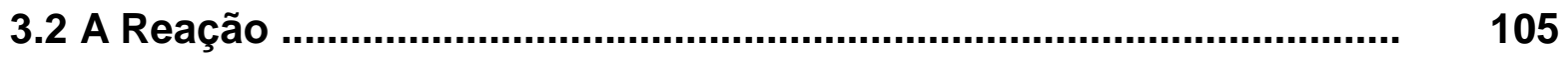

CAPÍTULO 4 - ROMANTISMO E HISTÓRIA NAS PÁGINAS DE IL

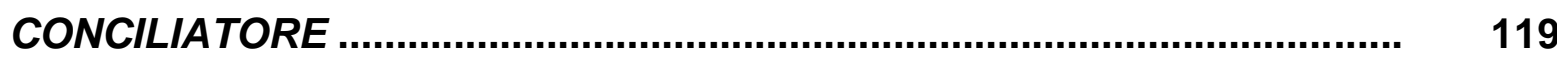

4.1 A Crítica Romântica ...................................................................... 119

4.2 A Visão Romântica da História ......................................................... 154

CONSIDERAÇÕES FINAIS ................................................................. 170

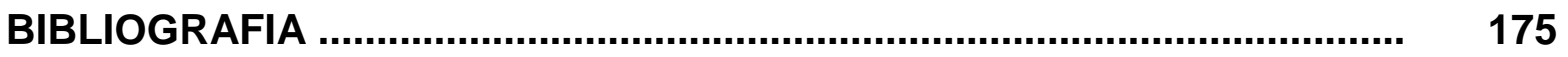

ÍNDICE DAS ILUSTRAÇÕES .............................................................. 


\section{AGRADECIMENTOS}

Qualquer tese de doutoramento é um trabalho por vezes longo e solitário e por isso é necessário contar com pessoas que, muito embora não participem diretamente na redação do trabalho, colaboram de maneira decisiva em sua realização. Gostaríamos de agradecer imensamente à nossa orientadora Prof. ${ }^{\text {a }}$ Dr. ${ }^{\text {a }}$ Sara Albieri, que sempre nos ouviu, incentivou, mostrou-se verdadeiramente comprometida com nosso projeto de pesquisa e não poupou esforços para minimizar as inevitáveis dificuldades inerentes a uma empreitada de tal magnitude.

Agradecemos também ao Programa de História Social do Departamento de História da Faculdade de Filosofia, Letras e Ciências Humanas da Universidade de São Paulo por ter acolhido o nosso projeto de pesquisa.

Também foi fundamental para a realização desse trabalho o apoio financeiro do Conselho Nacional de Desenvolvimento Científico e Tecnológico.

Agradecemos ao Istituto Italiano di Cultura de São Paulo, na pessoa de seu diretor Dr. Renato Poma, o apoio que nos foi concedido e sem o qual dificilmente esta pesquisa teria sido realizada, uma vez que a maior parte da bibliografia consultada pertence ao acervo de sua biblioteca.

Não esqueceremos a contribuição de Sônia Maria Guimarães, que em suas viagens à Itália nos abasteceu com materiais e informações muito relevantes para o andamento de nossa pesquisa. Foi Sônia quem comprou, em Veneza, a edição facsimilar de II Conciliatore, edição de 1981, rara e difícil de achar, sem a qual esta tese teria sido praticamente impossível. A ela também devemos a digitalização da parte iconográfica de nosso trabalho.

Gostaríamos de estender nossos agradecimentos aos funcionários do Departamento de História e também àqueles da Administração de nossa faculdade, que sempre mostraram-se solícitos em orientar-nos através dos meandros burocráticos de nossa universidade. E não podemos esquecer o apoio profissional de Antonio Carlos Cabral, responsável pela digitação e pelo tratamento gráfico da iconografia de nosso trabalho.

Minha mãe, Júlia Kowaleski de Barros, esmerou-se em proporcionar-me conforto e bem-estar nesses anos todos para que eu pudesse dedicar-me integralmente à minha pesquisa.

A todos vocês o nosso sincero agradecimento. Muito obrigado. 
Verrà giorno in cui Il Conciliatore

tornerà a rívívere

Súlvio Pellico 


\title{
RESUMO
}

Este trabalho investiga como as ideias românticas foram introduzidas na Itália após 1816. Isso é feito através da análise de artigos do periódico milanês // Conciliatore. Esse jornal literário circulou em Milão de setembro de 1818 a outubro de 1819 e teve entre seus colaboradores Silvio Pellico, Giovanni Berchet, Ermes Visconti entre vários outros. Nosso objetivo é abordar o nosso objeto de estudo em duas perspectivas: nós exploramos o papel de II Conciliatore como difusor das concepções românticas na Itália e procuramos, através de seus artigos, reconstruir algumas visões históricas contemporâneas ao período da Restauração Italiana.

Palavras-chaves: I| Conciliatore, Movimento romântico italiano, Romantismo, História Intelectual

\begin{abstract}
This work investigates how romantic ideas were introduced in Italy after 1816. It is done through the analysis of articles from the Milanese periodic II Conciliatore. This literary newspaper circulated in Milan from September 1818 to October 1819, having as its contributors Silvio Pellico, Giovanni Berchet, Ermes Visconti among a lot of others. Our aim is to approach our studying object by two perspectives: we explore II Conciliatore's role in spreading romantic conceptions in Italy and we seek through its articles to reconstruct some historical views contemporary to the Italian Restauration period.
\end{abstract}

Keywords: II Conciliatore, Italian romantic movement, Romanticism, Intellectual History, 


\section{INTRODUÇÃO}

Em janeiro de 1816 começou a circular em Milão a Biblioteca italiana, ossia Giornale di Letteratura, Scienze ed Arti compilato da una società di letterati. Esse jornal era patrocinado pelo governo austríaco e tinha como principal objetivo integrar a Lombardia nas discussões culturais do Império dos Habsburgos.

Foi na Biblioteca italiana que Madame de Staël (Ana Luisa Germana de Staël-Holstein) publicou, ainda em janeiro de 1816, o artigo Sulla Maniera e L'Utilità Delle Traduzioni, no qual argumentava, em linhas gerais, que os italianos deveriam se apegar menos à sua literatura autóctone e se interessar mais pelas novas propostas estéticas provenientes do norte da Europa. Em abril de 1816 apareceu no mesmo jornal outro artigo intitulado Un Italiano Risponde Al Discorso Della Staël, que embora anônimo hoje sabe-se ter sido escrito por Giovanni Gherardini. O argumento da resposta era que a Itália possuía uma cultura milenar e não necessitava de ideias ou proposições estrangeiras para modernizar o seu fazer artístico-literário. ${ }^{1}$ Será em torno dessas duas posições que se desenvolverá o debate entre clássicos e românticos na Itália, tendo Milão como epicentro. Se por um lado os primeiros apegavam-se à Mitologia e à tradição romana, exaltando Horácio e Virgílio e a língua latina; os segundos favoreciam a História e as tradições populares da Idade Média, louvando Dante e Petrarca e a língua italiana. ${ }^{2}$

É nesse clima de crescente animosidade que um grupo de literatos, alguns dos quais haviam anteriormente colaborado com a Biblioteca italiana, decide fundar um jornal para defender as ideias românticas. Esse jornal chamar-se-á II Conciliatore. Foram participantes desse grupo ${ }^{3}$ :

- Ludovico Arborio Gattinara Dei Marchesi Di Breme, mais conhecido como Ludovico di Breme (Turim, 1780 - Turim, 15 de agosto 1820)

- Silvio Pellico (Saluzzo, 25 de junho de 1789 - Turim, 31 de janeiro de 1854)

- Pietro Borsiere (Milão, 1786 - Belgirate, 5 de agosto de 1852)

\footnotetext{
${ }^{1}$ Carlo Salinari. Storia Popolare della Letteratura Italiana, volume III, Dalla seconda metà del Settecento al Novecento, pp 91 a 98. Os dois artigos citados, o de Madame de Staël e o de Giovanni Gherardini, encontramse reproduzidos na antologia de Egidio Bellorini. Discussioni e Polemiche Sul Romanticismo (1816-1826).

${ }^{2}$ A propósito da substituição da Mitologia pela História nos argumentos poéticos, assim como do fascínio pela Idade Média em detrimento da Antiguidade Clássica ver Friedrich Schlegel. Conversa sobre a poesia in Conversa sobre a poesia e outros fragmentos, pp 29 a 80. Já para uma análise mais localizada consultar G. A. Borgese. Storia della critica romantica in Italia.

${ }^{3}$ Todos os nomes a seguir são verbetes na Enciclopedia Italiana di Scienze, Lettere ed Arti.
} 
- Giovanni Berchet (Milão, 23 de Dezembro de 1783 - Turim, 23 de dezembro de 1851)

- Gian Domenico Romagnosi ( Salsomaggiore, 11 de dezembro de 1761 - Milão, 8 de junho de 1835)

- Ermes Visconti (Milão, 15 de março de 1784 - Crema, 21 de janeiro de 1841)

- Giuseppe Pecchio (Milão, 15 de novembro de 1785 - Brighton, 10 de março de 1835)

- Giovanni Rasori (Parma, 20 de agosto de 1766 - Milão, 23 de abril de 1837)

- Federico Confaloniere (Milão, 6 de outubro de 1785 - Hospenthal, 10 de dezembro de 1846)

- Jean-Charles-Léonard Sismonde de Sismondi (Genebra, 9 de maio de 1773 Genebra, 25 de junho de 1842)

- Giovanni Battista de Cristoforis (Milão, 11 de novembro de 1785 - Milão, 20 de junho de 1838)

- Luigi Porro Lambertenghi (Como, 1780 - Milão, 9 de fevereiro de 1860)

- Adeodato Ressi (Cervia, 4 de setembro de 1768 - Veneza, 8 de janeiro de 1822)

A principal preocupação desses intelectuais, quase todos nascidos na década de 1780 (e portanto com mais de trinta anos à época do lançamento de II Conciliatore, em 1818), era o atraso não só econômico mas sobretudo cultural da Itália em relação aos demais países europeus. Foi por isso que, conforme nos conta Carlo Calcaterra ${ }^{4}$, a princípio o jornal deveria chamar-se II Bersagliere (o atirador), mas chegou-se à conclusão de que não era possível (e nem tampouco desejável) fazer na Itália aquilo que o movimento pré-romântico Sturm und Drang procurara fazer na Alemanha durante a segunda metade da década de 1770: romper com o passado e apagar as influências do lluminismo de matriz francesa. Assim, a inserção da Itália na nova cultura europeia pós-Revolução Francesa e pósneoclassicismo deveria ser feita valorizando a cultura clássica (Dante, Petrarca, Ariosto, Tasso), que havia tornado a península uma referência. Na verdade, a disputa era com aqueles que insistiam em aprisionar a criação artística em modelos que vinham sendo usados desde o Renascimento. Por essa razão optou-se por chamar o jornal de II Conciliatore. Essa tendência a harmonizar o presente

\footnotetext{
${ }^{4}$ Carlo Calcaterra. Ludovido di Breme e Il Conciliatore in Mario Fubini e Ettore Bonora (org). Antologia della critica letteraria, volume 3, Dall'Arcadia agli inizii del Novecento. Sobre as origens do nosso jornal ver também Francesco de Sanctis. La letteratura italiana nel secolo decimonono, p 109
} 
romântico com o passado clássico determinou os rumos do movimento romântico italiano, diferenciando-o daqueles movimentos românticos na Inglaterra e na Alemanha. $^{5}$

De acordo com Carmelo Cappuccio, "Il Conciliatore, nos seus 118 números, chamou a atenção dos leitores para, entre outros, as obras de Byron, de Schiller, de Pindemonte, de Gessner, de Goethe; para os Inni Sacri, de Manzoni; para as tragédias de Shakespeare; criou polêmicas e despertou a juventude italiana para novos estudos." 6 E justamente por tentar definir o papel da Itália nesse novo contexto cultural, o jornal acabou por exaltar o patriotismo italiano e foi alvo, desde o começo, da censura policial austríaca. ${ }^{7}$

Os dois primeiros decênios do século XIX foram sobremaneira turbulentos na Itália. Território tampão entre a França regicida e o Império Habsburgo, foi na Península que se deu a maioria dos embates militares entre os dois estados beligerantes.

No período napoleônico a Península Itálica foi considerada como espaço vital para a segurança do território francês, sendo a sua ocupação militar uma questão prioritária para o império bonapartista. ${ }^{8}$

Anos antes, em meados da segunda metade do século XVIII, começara a germinar, entre a elite dirigente dos diversos estados italianos, a ideia de que a decadência cultural e o atraso econômico da Itália deviam-se ao fato de que seu território era dividido. Os impostos aduaneiros nos portos do Mar Tirreno e do Mar Adriático; as dificuldades de locomoção terrestre em virtude das estradas precárias; a diversidade da legislação pertinente a propriedades e heranças eram preocupações recorrentes entre os homens de corte durante o período préRevolução Francesa, ou da llustração.

\footnotetext{
${ }^{5}$ Para uma visão mais detalhada das peculiaridades do movimento romântico italiano consultar Francesco Flora. Storia della Letteratura Italiana, volume III, parte I, L'Ottocento, pp 96 a 109. Ver também a respeito o ensaio de Umberto Bosco Romantismo e Realismo, escrito em 1949 e incluído em seu livro Realismo romantico, pp 11 a 78

${ }^{6}$ Carmelo Cappuccio. Storia della Letteratura Italiana, p 486 (nossa tradução)

${ }^{7}$ Vittorio Rossi. Storia della Letteratura Italiana per uso dei licei, volume terzo, L'età moderna, pp 285 a 293

${ }^{8}$ Um estudo bastante aprofundado desse período nos é fornecido por Cesare Spellanzon. Storia del Risorgimento e dell'unità d'Italia. Outro livro esclarecedor é Giorgio Candeloro. Storia dell'Italia Moderna, volume I, Le Origini del Risorgimento (1700-1815)
} 
Com as invasões francesas a partir de 1798, e a posterior divisão do território peninsular em Reino da Itália e Reino de Nápoles, em 1805, como parte integrante do Império Francês, várias dessas questões foram resolvidas. Tanto o vice-rei da Itália, Eugênio Beauharnais, quanto o rei de Nápoles, Joaquim Murat, unificaram legislações e aduanas, assim como melhoraram de forma considerável a infraestrutura de seus reinos. Esses esforços se explicavam pela necessidade de cobrar impostos (legislação e aduanas) e facilitar o deslocamento de tropas (infraestrutura). ${ }^{9}$

Foi por isso que a divisão arbitrária da Península Itálica em onze estados independentes efetivada pelo Congresso de Viena, em 1815, ocasionou uma onda geral de insatisfação entre os italianos. Voltava-se à situação de vinte e cinco anos antes, porém com uma geração crescida e educada sob novos conceitos políticos e novas ideias econômicas, e por isso mesmo, muito menos disposta a aceitar um estado de coisas na administração pública que já havia causado incômodos à geração anterior. A resposta a essa condição foi a repressão política (maior ou menor dependendo da situação das onze unidades políticas em que a Itália então se dividia) e a atuação subversiva das sociedades secretas (também elas mais ou menos atuantes em cada estado peninsular).

Milão fora, entre 1805 e 1814, a capital do Reino da Itália e, após a partilha do território peninsular feita pelo Congresso de Viena, em 1815, tornou-se a capital do Reino Lombardo-Vêneto, que por sua vez integrava o Império Austríaco, governado pelos Habsburgos. A cidade era há duzentos anos o que é hoje em dia: um dos grandes centros cosmopolitas da Europa, catalisador de modas e ideias, assim como difusor de tendências. ${ }^{10}$

O período que vai do Congresso de Viena, em 1815, até a eclosão das chamadas revoluções liberais, em 1821, marca o predomínio, no campo político, da Santa Aliança e de sua luta renhida contra as reminiscências da Revolução Francesa e do Império Napoleônico. A Restauração, tanto em França como em Itália (embora em graus diferentes) buscava cancelar o passado recente e remontar aos usos e costumes em vigor na década de 1770. Porém, a impossibilidade prática

\footnotetext{
${ }^{9}$ Essas transformações foram bem analisadas em Stuart J. Woolf. La Storia Politica e Sociale in Ruggiero Romano e Corrado Vivanti (org). Storia d'Italia, volume terzo, Dal Primo Settecento all'Unità, pp 150 a 295. Pode ser complementado com Paolo Rossi. Storia d'Italia dal 1500 al 1815, pp 283 a 349

${ }^{10}$ Giorgio Candeloro. Storia dell'Italia Moderna, volume II, Dalla Restaurazione alla rivoluzione nazionale (1815-1846), pp 9 a 158. Ver também Cesare Spellanzon. Op cit.
} 
da abolição de vários direitos civis e da reintrodução de diversos privilégios aristocráticos criou espaços para a discussão de novas formas de organização social e econômica, que aprofundaram divergências ideológicas criando dois grupos antagônicos: absolutistas/clássicos versus liberais/românticos.

O Romantismo, como fenômeno transformador da cultura e da vida do ocidente, foi gestado por longos anos desde o princípio do século XVIII. Suas origens podem ser rastreadas no sensismo do Conde de Shaftsbury e nas melancólicas gravuras das paisagens escocesas da década de 1750 . Transportadas para a Alemanha, essas concepções soturnas de lugares solitários banhados por um luar frio ganharam um corpo teórico que embasou a reação germânica ao gosto clássico de matriz francesa. Dos pré-românticos do movimento Sturm und Drang (Tempestade e Ímpeto), dos anos 1770, à geração de 1805, vamos encontrar uma preferência exagerada pelo Sentimento, pela Fantasia, pela Idade Média e seus cavaleiros, fadas e feiticeiros.

O ano de 1798 pode ser considerado um marco na história do Romantismo. Foi nesse ano que surgiu na Alemanha a revista Athenaeum, editada pelos irmãos Friedrich e August Wilhelm Schlegel, e na Inglaterra foram publicadas as Lyrical Ballads, de Coleridge e Wordsworth. A valorização do caráter individual dos povos (Volksgeist), a reação violenta à Razão como mediadora entre o Homem e a Natureza, e, especialmente relevante para o nosso estudo, a substituição dos motes mitológicos por enredos históricos são as principais características dessa nova forma de abordagem da cultura ocidental. ${ }^{11}$

É importante notar que fazemos uma distinção entre Romantismo e movimentos românticos. O primeiro é um conjunto de características que a cultura ocidental adquire no final do século XVIII, que muito embora não fossem novas combinavam-se de uma maneira diferente num esforço renovador. Assim, o Particular ganha prevalência sobre o Geral; as trevas tornam-se mais atraentes que a Luz; a Subjetividade é considerada mais repleta de significados do que a

\footnotetext{
${ }^{11}$ Com relação à nova sensibilidade instaurada pelo Romantismo, ver Mario Praz. A Carne, a Morte e o Diabo na Literatura Romântica. Para uma análise das ideias que embasaram as produções artísticas do período é muito valioso o livro de Walter Benjamin. O conceito de crítica de arte no Romantismo alemão.
} 
Objetividade; a Ação, e não a Reflexão, passa a ser um elemento de valorização dos indivíduos. De um modo amplo nós podemos dizer que tudo aquilo que é local, subjetivo e exaltado constitui o Romantismo.

Os movimentos românticos são a maneira pela qual o Romantismo foi introduzido nas diferentes sociedades ocidentais. Coerentes com a proposta de valorização do elemento local, que é uma das características fundamentais da ideologia romântica, os diversos grupos de artistas e intelectuais que se propuseram a adotar em suas obras os postulados da nova escola o fizeram de maneiras díspares. Por isso podemos falar de romantismo alemão, romantismo brasileiro, romantismo inglês, etc.

A peculiaridade do movimento romântico italiano é a sua atuação política. $\mathrm{Na}$ segunda metade do século XVIII, a elite letrada que fazia parte da administração dos vinte e cinco estados que então compunham a Península Itálica começou a convergir, dentro dos limites impostos pela ilustração e pelo absolutismo monárquico, para a conclusão que os problemas de atraso econômico e cultural que assolavam seus territórios eram devidos à divisão política da Itália. Ou seja, para a intelectualidade italiana do período pré-revolucionário a unificação peninsular era a solução. Foi por isso que muitos italianos ilustres saudaram Napoleão Bonaparte como libertador e foram seus partidários entusiasmados.

Os percalços sofridos na primeira década do século XIX, tais como o saque das obras de arte e dos tesouros de cidades como Veneza, Milão e Florença. Os abusos cometidos pelas forças francesas nos dois reinos itálicos sob seu domínio e as duas restaurações dos Bourbon no Reino de Nápoles convenceram a geração letrada nascida nas décadas de 1780 e de 1790 que somente os italianos poderiam resolver os problemas da Itália. ${ }^{12}$

Contudo, queremos investigar aqui que em suas raízes, o movimento romântico italiano era movido sobretudo por uma questão da cultura intelectual. No período que estamos analisando, qual seja, os anos que se estendem do Congresso de Viena, em 1815, até a eclosão das revoluções liberais, em 1821, a intelectualidade italiana divide-se em dois grupos distintos: os que defendem as raízes greco-romanas como elemento diferenciador da cultura peninsular em relação ao restante da Europa (neo-clássicos) e os que argumentam que essa herança da

\footnotetext{
${ }^{12}$ Giorgio Candeloro. Storia dell'Italia moderna, volume I, Le Origini del Risorgimento (1700-1815), pp 169 a 375. Ver também os livros de Cesare Spellanzon e Paolo Rossi citados nas notas 8 e 9
} 
Antiguidade é um cadáver que está há muito tempo insepulto, e que a cultura italiana precisa de um novo paradigma (românticos).

Para os românticos a Itália moderna não descende dos romanos e sim dos povos germânicos que foram responsáveis pela destruição de seu império. Dentro dessa visão a decadência da cultura italiana está ligada aos modelos estéticos do Renascimento, que já não respondem às necessidades de um mundo que guilhotinou um rei, depôs governos e colocou o indivíduo como protagonista de seu destino. Por isso, é na ldade Média que se deve buscar a verdadeira matriz da cultura peninsular. Nas cidades-estado e sua organização política; na língua de Dante e Petrarca; nos feitos dos cruzados e dos negociantes-aventureiros, tais como Marco Polo; nos confrontos entre muçulmanos e cristãos na Sicília. Aí está a verdadeira Itália: não mais na Mitologia, e sim na História. ${ }^{13}$

II Conciliatore já no seu programa (escrito por Pietro Borgieri em $1^{\circ}$ de julho de 1818) propunha-se a ser um jornal que abriria espaço para discutir as ideias do seu tempo. Assim o fez, muitas vezes de forma jocosa e bem humorada. $\mathrm{Na}$ opinião de Pier Angelo Menzio, "talvez o desejo do novo e a náusea do velho possam também ser apontados como uma característica peculiar do Conciliatore (assim como da escola romântica no geral): onde se explica a fobia pelas línguas clássicas e a aversão às fastidiosas pesquisas de arquivo." 14 Os diversos colaboradores do jornal desenvolvem suas ideias através de resenhas, em diálogos cômicos, algumas crônicas mundanas, ensaios literários e nas cartas enviadas para a redação. Sobre esse grupo de escritores (também chamado de i conciliatori) Aldo Vallone assegura que "jamais um periódico aparecido na Itália se apresentou, em tantas seções variadas, tão concorde e unitário: sinal de uma unidade de entendimento." 15 Essa "unidade de entendimento" se reflete em uma preocupação constante com o Passado.

\footnotetext{
${ }^{13}$ Ettore Passerin d'Entrèves. Ideologie del Risorgimento in Emilio Cecchi e Natalino Sapegno (org). Storia della Letteratura Italiana, volume VII, L'Ottocento, pp 183 a 263. Ver também Mario Fubini. La Polemica Romantica (1947) in Romanticismo Italiano, Saggi di storia critica e della letteratura. Pode ser complementado por Carmello Cappuccio. Storia della Letteratura Italiana. Para uma visão um pouco anterior, da virada do século XIX para o século XX, ver G. A. Borgese. Storia della critica romantica in Italia

${ }^{14}$ Pier Angelo Menzio (org). Dal Conciliatore, pp 13 e 14 (nossa tradução)

${ }^{15}$ Aldo Vallone. Dal Caffè al Conciliatore, Storia delle idee, p 85 (nossa tradução)
} 
Com apresentação de Silvio Pellico, II Conciliatore publicou em quatro números $(2,6,10,11)$ extratos do livro de Melchiorre Gioia, Del Merito e Delle Ricompense. A obra em questão examina como o mérito foi apreciado em diferentes épocas históricas: nos tempos homéricos a força física era muito valorizada; entre os Celtas ao tempo do Império Romano era meritória a destreza com armas; Carlos Magno, segundo Gioia, foi aclamado pelo povo de Roma devido a sua elevada estatura, já que na Idade Média a perfeição corporal era fator de distinção. O livro mostra como o conceito de mérito variou entre diversos povos ao longo dos tempos, da Antiguidade até a Revolução Francesa.

Ludovido Di Breme escreve uma resenha do livro de Juan Antonio Llorente, Storia critica della inquisizione in Spagna, cuja versão em francês aparecera em 1817. Os comentários do colaborador se estendem por três números de II Conciliatore: 3, 4 e 11. Di Breme, faz ácidos comentários ao Santo Ofício no primeiro artigo, mas procura colocá-lo como um produto de um determinado tipo de sociedade. No segundo ele conta histórias de processos ocorridos principalmente na cidade de Valladolid, mostrando a que ponto pode chegar a crueldade humana quando encontra amparo na ignorância dos povos e na intolerância dos eclesiásticos. No terceiro e último artigo Di Breme comenta como o medo gerado na sociedade espanhola pela Inquisição (notadamente pelas execuções de membros da nobreza) impossibilitou um progresso intelectual e mesmo material da Espanha, levando o Império Espanhol à decadência.

No número 8 aparece a resenha de Gian Domenico Romagnosi sobre o livro Compendio storico della grande emigrazione dei popoli barbari, cujo autor é indicado pelas iniciais L. C. D. R.. A obra versa sobre as invasões de Átila, Alarico, Genserico e Tótila, além da ocupação da Espanha pelos árabes. De acordo com Romagnosi a principal tese do autor é que os povos pastoris são mais belicosos do que os povos agricultores, pois estes se fixam à terra enquanto aqueles estão sempre se deslocando em busca de pasto para seus rebanhos.

Giovanni Berchet, que assinava todos os seus artigos para II Conciliatore como Grisostomo, escreve no número 4 uma interessante crônica chamada Del criterio ne' discorsi. O autor conta que tomava chá em companhia de um lorde inglês seu amigo, que estava de passagem por Milão, quando o tema da conversa resvalou para o assunto mulheres. O lorde inglês concordava com Grisostomo que as damas milanesas eram bonitas, elegantes, refinadas, que sua educação tinha 
progredido muito porém não admitia que elas possuíssem um juízo acurado, e teimava em imputar-lhes uma total fala de critério em suas opiniões. Ferido em sua dignidade de milanês, Grisostomo intima o amigo a explicitar a tal falta de critério de suas conterrâneas e o lorde inglês, apesar de mostrar-se contrariado, acaba por afirmar que as milanesas não sabem a diferença entre clássico e romântico. Diante da surpresa do autor o lorde inglês passa a dar numerosos exemplos tirados de suas conversas com as damas. Como amostra da prosa de II Conciliatore traduziremos um trecho do discurso do lorde inglês: "Se as senhoras que eu conheço possuem such a great deal de critério por que não são mais cautelosas em suas conversas? Por que não evitam aventurar-se em regiões desconhecidas? Por que não param de repetir, todo o santo dia, palavras as quais não têm a mínima ideia do que significam? - Me dirão que é a moda que assim exige. E não poderei, então, justamente dizer que essa moda é a very nonsensical petulancy? Ouvi uma queixar-se de que a forma do seu leque era mais clássica do que romântica All nonsense! - Uma outra perguntava a um amigo se, uma vez que ele era romântico, não Ihe permitiria usar essências odoríferas. - All nonsense! - Uma outra admirava uma gravura de Gozzi e Ihe parecia que esta fosse clássica demais.

- All nonsense! - A coitadinha acreditava talvez que clássico servisse precisamente de antônimo ao nosso velho adjetivo inglês - romantic - que possui um significado totalmente diverso daquele atribuído ao novo termo literário dos dias atuais; que na verdade é uma coisa totalmente diferente, como sabe qualquer um que apenas se interesse por tais coisas." A crônica prossegue nesse tom, mostrando que se a discussão entre clássicos e românticos era um tema de conversas mundanas, a compreensão do que fosse romântico não era absolutamente clara.

No número 3 de II Conciliatore, Gian Domenico Romagnosi escreveu o artigo Della poesia considerata rispetto alle diverse età delle nazioni para responder à pergunta: você é clássico ou romântico? O autor se declara ilichiastico, que em grego, segundo ele, significa adaptado ao seu tempo. Romagnosi argumenta que um italiano não pode ser totalmente clássico por que isso significaria um afastamento da cultura europeia moderna e nem totalmente romântico por que teria de abdicar de suas origens e repudiar a herança de seus antepassados. Ele transcreveu em seu artigo duas passagens (em francês) do livro de Madame de Staël, De l'Allemagne. Ao final, Romagnosi diz não querer uma poesia italiana 
morta e nem tampouco que seus compatriotas sejam seduzidos por ideias estéticas importadas do norte da Europa, que não se aplicam assim tão facilmente à Itália.

Silvio Pellico discute em dois artigos, publicados nos números 2 e 8 as ideias expostas no livro Vera idea della tragedia di Vittorio Alfieri, de Gaetano Marrè, professor de direito comercial na Real Universidade de Gênova, publicado em 1817. Pellico critica o autor por tentar estabelecer equivalências entre as tragédias de Vittorio Alfieri e as tragédias gregas. Seu argumento é que não se pode escrever uma tragédia nos moldes gregos para um público moderno, uma vez que esse público demanda um tipo de encenação e de interpretação totalmente diverso das máscaras e coturnos dos atores da Antiguidade. Pellico afirma que a discussão sobre o gênero trágico não está bem formulada. Não se trata de saber se uma tragédia assemelha-se mais ou menos às obras dos tragediógrafos gregos, porém, em suas palavras, "Quais são as ações heróicas que mais importam ser celebradas na Itália? As nacionais ou as estrangeiras? As mitológicas ou as históricas? As antiquíssimas ou as mais próximas do nosso século?” (nossa tradução). Nesse ponto ele se aproxima de Romagnosi e de outros colaboradores de II Conciliatore ao clamar por obras poéticas e dramáticas consoantes com o mundo pós Revolução Francesa.

Giovanni de Cristoforis, no número 6, faz uma resenha do livro Sulla poesia, sermone di Giovanni Torti, editado pela tipografia de Vincenzo Ferrario, a mesma onde é impresso II Conciliatore. O argumento é que o autor usa demais a mitologia em seus poemas, que são belos mas pouco dizem ao leitor coevo. De Cristoforis conclui que Torti serviria melhor às letras italianas se usasse seu talento e seu estilo elegante tratando de temas criados por sua própria imaginação. Acrescentaríamos nós, se ele fosse romântico e não clássico.

Existem também artigos e resenhas sobre medicina, metalurgia e viagens. Era comum uma resenha ou mesmo uma crônica serem publicadas em partes ao longo de vários números não sequenciais, como pudemos observar em alguns exemplos citados. Como salientou o crítico e historiador G. A. Borgese, "a harmonia da obra com os tempos que a produziram era, em resumo, a preocupação contínua dos homens do Conciliatore". 16 Por isso, a maioria das matérias se refere à

\footnotetext{
${ }^{16}$ G. A. Borgese. Storia della critica romantica in Italia, p 135 (nossa tradução)
} 
Literatura e à História, o que justifica o título de nosso trabalho: Romantismo e História nas Páginas de II Conciliatore.

II Conciliatore é um documento original de um tempo muito diferente do nosso, mas a leitura de seus 118 números pode nos mostrar que vários dos limites e dos dilemas da cultura de uma época pós-industrial como a que hoje vivemos já estavam esboçados no início da Idade Contemporânea. Estudar os primórdios da nossa cultura, hoje chamada de pós-moderna, buscando estabelecer correlações entre as preocupações estéticas e as posições críticas de diferentes etapas da contemporaneidade nos permite traçar um quadro mais nítido das ideias de nosso próprio tempo. 


\section{CAPÍTULO 1 A ERA ROMÂNTICA: O CENÁRIO HISTÓRICO-POLÍTICO}

Johann Wolfgang von Goethe nasceu em Francoforte-sobre-o-Meno no dia 28 de agosto de 1749 e morreu em Weimar no dia 22 de março de 1832. Sua longa vida se estendeu por uma época de profundas mudanças econômicas, políticas e geográficas que talvez só tenham paralelo na história ocidental com o período da Renascença, embora as transformações renascentistas possuam uma abrangência menor. Com efeito, quando Goethe veio ao mundo, em 1749, quase todos os governos da Europa eram monarquias absolutas; as três Américas eram colônias europeias; os artesãos ainda trabalhavam em oficinas rudimentares, equipadas com máquinas manuais; uma parcela considerável da população residente nos campos vivia sob um regime de trabalho não muito diferente daquele vigente na Idade Média. Em 1832, ano do falecimento de Goethe, as monarquias absolutas já haviam sido, em sua maior parte, abolidas pelas revoluções liberais; o território americano estava dividido em diversas repúblicas independentes, e existia na América do Sul uma monarquia constitucional, o Brasil; as máquinas a vapor haviam dado um grande impulso à produção de manufaturas; e grande parte da legislação herdada do Feudalismo, que regera as relações econômicas na agricultura europeia, fora revogada pelas revoluções da década de 1820 . Em resumo, Goethe nasceu em um mundo e morreu em outro. ${ }^{17}$

Qualquer historiador que se proponha a analisar as mudanças ocorridas no Ocidente na segunda metade do século XVIII e nas três primeiras décadas do século XIX terá diante de si uma empreitada de fôlego. Os acontecimentos históricos desenrolam-se de forma abrupta, em uma torrente que abarca vários povos e territórios, na Europa e fora dela. São a esses anos convulsos que chamaremos neste estudo de Era Romântica. Na opinião de Nachman Falbel, "o período do Romantismo é fruto de dois grandes acontecimentos na história da Humanidade, a Revolução Francesa e suas derivações e a Revolução Industrial." Podemos dizer que o adjetivo revolucionária define de maneira clara e objetiva toda

\footnotetext{
${ }^{17}$ A respeito deste parágrafo consultar Goethe. Memórias: Poesia e Verdade; Eric J. Hobsbawn. A Era das Revoluções e William Otto Henderson. A Revolução Industrial 1750-1914.
} 
essa época. Na década de 1770 ocorreu a Revolução Americana (1776-1783); entre 1787 e 1790 os Países Baixos austríacos sublevaram-se contra o despotismo esclarecido de José II; em 1789 eclodiu a Revolução Francesa; e de 1788 a 1794 a onda revolucionária atingiu a Polônia e convulsionou o leste europeu. Em todos esses casos clamava-se por liberdade, por mudanças políticas e sobretudo por um novo ordenamento sócio-econômico. Se podemos achar um denominador comum a esses movimentos revolucionários este é a abolição dos privilégios reais e o compartilhamento do poder político (até então monopólio da Aristocracia) com outras classes sociais, especialmente a Burguesia. Com o passar dos anos, nas palavras de Falbel, "tais revoluções se alastraram inevitavelmente a outros continentes, encontrando solo fértil nas colônias espanholas da América e outras regiões do continente europeu." 18 Acrescentaríamos que o grande vetor desse espírito revolucionário definidor da Era Romântica foi a expansão francesa ocorrida nos primeiros anos do século XIX, conduzida por Napoleão Bonaparte. Ele levou, na ponta de sua espada e nas balas de seus canhões, o lema "Liberdade, Igualdade e Fraternidade" a vários rincões do mundo ocidental, abalando irremediavelmente as estruturas do absolutismo monárquico.

Outro fato notável desse período histórico foi o progresso demográfico. É possível inferir que o acréscimo populacional, que gerou um grande contingente de pessoas jovens, está diretamente relacionado ao espírito revolucionário da época. De acordo com Eric J. Hobsbawn, "o extraordinário aumento da população estimulou muito a economia" e fez com que os ganhos de produção e de consumo proporcionados pela evolução tecnológica que conhecemos pelo nome de Revolução Industrial fossem abrangentes e duradouros. Na opinião do historiador britânico, caso essa expansão demográfica não tivesse ocorrido o desenvolvimento econômico e a acumulação de capital que ele proporcionou "não poderia ter sido mantido durante mais do que um limitado período." A Revolução Industrial, ainda segundo Hobsbawn, "produziu mais trabalho, sobretudo mais trabalho jovem e mais consumidores. O mundo desse período foi bem mais jovem do que qualquer outro anterior: cheio de crianças, com jovens casais ou pessoas no auge da juventude." 19 Em nossa hipótese interpretativa, tal configuração populacional propiciaria aos

\footnotetext{
18 Nachman Falbel. "Os Fundamentos Históricos do Romantismo" in J. Guinsburg (org). O Romantismo, p. 24

${ }^{19}$ Eric J. Hobsbawn. A Era das Revoluções, p. 189
} 
artistas dessa época a exaltação do Amor, da Coragem e da Audácia, que são características de pessoas jovens. Vale também recordar que o Romantismo, em muitas de suas representações, figurou a Velhice como um estado de decrepitude e de decadência. Muitos românticos descrevem a geração mais velha como arraigada a preconceitos e a um estilo de vida anacrônico, em permanente embate com as ideias dos novos tempos. Na Era Romântica a Europa foi povoada por gente moça: uma mocidade cheia de sonhos, ambições e desejos.

É razoável conjecturar que as distâncias na segunda metade do século XVIII, ao menos em território europeu, eram mais curtas do que haviam sido cinquenta anos antes. Novas estradas e meios mais eficazes de navegação foram os responsáveis por um incremento no número de viagens e possibilitaram uma troca intensa de correspondências. Isso fez com que a sociedade jovem e turbulenta da Era Romântica estivesse muito mais próxima e informada sobre os acontecimentos do Mundo do que aquela de um século antes. Goethe relembra, em suas memórias, que no tempo de sua juventude "em geral, reinava na sociedade uma franqueza tão universal que não se podia falar nem escrever a ninguém sem considerar a comunicação como dirigida a várias pessoas." Nos saraus e reuniões sociais as cartas eram lidas para todos os presentes, que tinham assim pleno conhecimento das relações íntimas uns dos outros. O gênio romântico alemão nos conta "a indiferença dos governos com esse gênero de correspondência, a celeridade dos correios, a segurança do sinete, a modicidade dos portes, favoreceram o rápido desenvolvimento desse comércio moral e literário." Era um hábito recolher as cartas com pessoas ilustres e divulgá-las em extratos nas reuniões de amigos. Goethe acrescenta "se as discussões políticas ofereciam pouco interesse, todos estavam bem-informados das condições do mundo moral." 20 Acrescentaríamos, como exemplos ilustrativos dessa relação setecentista com as missivas, os romances epistolares As Relações Perigosas, de Choderlos de Laclos (1741-1803); A Nova Heloísa, de Jean Jacques Rousseau (1712-1778); e Os Sofrimentos do Jovem Werther, do próprio Goethe.

\footnotetext{
${ }^{20}$ Goethe. Memórias: Poesia e Verdade; Livro XIII, p. 424
} 


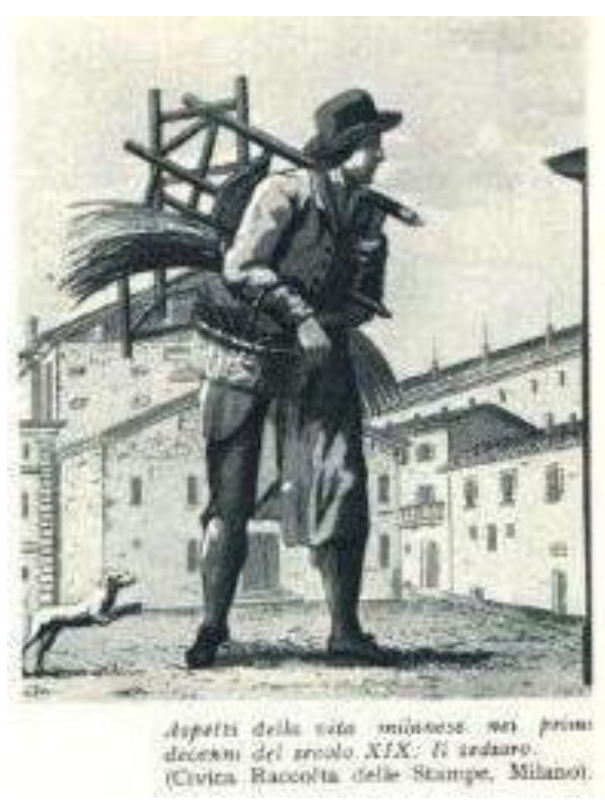

Cenas da vida milanesa nas primeiras décadas do século XIX: o fabricante de cadeiras (in Cesare Spellanzon. Storia del Risorgimento e dell'unità d'Italia, p.621)

O historiador grego Polibius (205 A.C.? - 125 A.C.?) escreveu no século II A.C. "o amor da novidade, inato nos homens, é capaz por si mesmo de provocar todas as revoluções." 21 Podemos inferir que em uma sociedade onde predominavam pessoas moças havia um terreno fértil para a discussão de novas ideias e para o surgimento de mudanças sócio-culturais. Segundo Aguinaldo José Gonçalves, após a Revolução Gloriosa de 1688 e a consolidação do sistema parlamentar que pôs fim às lutas político-religiosas, a Inglaterra pôde beneficiar-se deste ambiente de mudanças que procuramos esboçar neste estudo. Para o autor, "muitas das criações culturais e científicas mais avançadas vêm daquele país, que começa a tomar a dianteira nos processos de modernização." ${ }^{22}$ Um século mais tarde, ou seja, nas duas últimas décadas do século XVIII, no entender de Eric J. Hobsbawn, "tanto a Grã-Bretanha quanto o mundo sabiam que a Revolução Industrial lançada nestas ilhas não só pelos comerciantes e empresários como através deles (...) estava transformando o mundo." 23 Nossa hipótese de interpretação aponta o aparecimento, na Era Romântica, de formas de produção e de comércio que impulsionaram a criação de modalidades artísticas e intelectuais

\footnotetext{
${ }^{21}$ Polibius. História; XXXVI, 13

${ }^{22}$ Aguinaldo José Gonçalves. "O Classicismo na Literatura Europeia" in J. Guinsburg (org). 0 Classicismo, p. 134

${ }^{23}$ Eric J. Hobsbawn. Op cit, p. 69
} 
compatíveis com o desejo por novidades, já por nós identificado como uma das características desse período histórico.

Em nossa opinião não é possível dissociar a Revolução Industrial do panorama cultural dessa época porque as ideias renovadoras do pensamento ocidental que surgiram no século XVIII, e que foram enfeixadas sob o nome genérico de lluminismo, partilharam a crença no progresso da Humanidade através do conhecimento e do controle do Homem sobre a Natureza. Isso só foi possível, segundo Eric J. Hobbsman, porque essa ideologia derivava "sua força primordialmente do evidente progresso da produção, do comércio e da racionalidade econômica que se acreditava estar associada a ambos." 24 É razoável supor que sem o desenvolvimento tecnológico proporcionado pela máquina a vapor teria sido muito mais difícil acreditar que o Homem pudesse sobrepor-se à Natureza. Além disso, como sustentam Kátia Castilho Cunha e Ana Cláudia de Oliveira, "as mudanças sociais coincidem com a transformação decisiva da estrutura produtiva." ${ }^{25}$ Deixemos claro que produção e consumo sempre existiram, o fato novo era o volume produzido. Na época anterior à Revolução Industrial havia uma quantidade de bens disponível para o consumo básico, ou seja, não se fabricava além daquilo que pudesse ser absorvido pela Necessidade. A industrialização ampliou a capacidade de consumir, de forma que as pessoas não só podiam como deveriam ter mais roupas, louças, móveis, etc. Se anteriormente, no tempo dos artesãos e suas oficinas, a produção orientava o consumo (só era possível consumir aquilo que se pudesse produzir) na Era Romântica o consumo orientava a produção (a produção em larga escala exigia um consumo em escala ainda maior). É possível inferir que esse mercado consumidor começou a revelar novas nuances culturais que foram se acentuando com o correr do século XVIII. No campo literário o aumento do número de leitores foi possível graças ao surgimento de prensas mais modernas que possibilitaram a impressão de uma quantidade muito maior de livros, revistas e jornais. Os livros se transformaram em produtos acessíveis a uma nova classe média urbana, empregada no comércio e no setor financeiro. Já no final do

\footnotetext{
${ }^{24}$ Idem, pp 36-37

${ }^{25}$ Kátia Castilho e Ana Cláudia de Oliveira. "Moda e Classicismo" in J. Guinburg (org). Op cit, p. 333
} 
século XVIII, possuir uma biblioteca não era um privilégio reservado a príncipes e papas. ${ }^{26}$

Essa nova sociedade, urbana e cosmopolita, começava a dirimir as noções de classe herdadas do Feudalismo. Porém, a defasagem tecnológica, causa do desnível econômico das nações europeias, foi um legado da Revolução Industrial, que enriqueceu algumas regiões em detrimento de outras. As consequências sombrias desse processo de transformação não passaram despercebidas aos letrados da época. Segundo Roberto Aguinaga, "no Romantismo podemos entrever toda uma atitude de protesto e rejeição à forma como se verificava a expansão das forças produtivas." 27 Essa tendência se concretizou na exaltação do Passado em oposição ao Presente, na crítica ao Utilitarismo e na valorização da relação Indivíduo/Natureza. O incômodo com a noção de progresso econômico que então se disseminava e a oposição à classe social que mais se beneficiava com as transformações geradas pelas novas estruturas políticas (a Burguesia), em nosso entendimento, é uma das características dos movimentos românticos em geral. Já no início da década de 1790, Schiller (1759-1805) comentava "a Utilidade é o grande ídolo do tempo; quer ser servida por todas as forças e cultuada por todos os talentos." Os Românticos preocupar-se-ão em denunciar a vulgaridade da vida burguesa, a falta de senso estético da nova ordem econômica e serão os primeiros a ver como os indivíduos nas grandes aglomerações urbanas, que então começavam a formar-se, tornam-se massa, perdendo sua identidade. Em tal sociedade, para Schiller, "o mérito espiritual da Arte nada pesa, e ela, roubada de todo estímulo, desaparece do ruidoso mercado do século." 28

No entender de Eric J. Hobabawn, "entre todas as revoluções contemporâneas, a Revolução Francesa foi a única ecumênica. Seus exércitos partiram para revolucionar o mundo; suas ideias de fato o revolucionaram." ${ }^{29}$ Mas como isso foi possível? Em nossa opinião por que a expansão militar francesa,

\footnotetext{
${ }^{26}$ Para uma abordagem mais ampla dos temas tratados neste parágrafo (muito embora limitada à Grã-Bretanha) gostaríamos de remeter os leitores a E. J. Clery. The Rise of Supernatural Fiction (1762-1800) e E. P. Thompson. Os Românticos, a Inglaterra na era revolucionária.

${ }^{27}$ Roberto Aguinaga. "Introdução" in Barbey d'Aurevilly. As Diabólicas, pp 11-12

${ }^{28}$ Schiller. A Educação Estética do Homem numa série de cartas, carta II

${ }^{29}$ Eric J. Hobsbawn. Op cit, pp 72-73
} 
consequência do isolamento imposto ao regime revolucionário após a deposição de Luís XVI, estribou-se em uma nova concepção de Estado. Os franceses, quando ocupavam um território, traziam novas leis, novas formas de fazer justiça e maneiras diferentes de administração. Isso tornava a ocupação militar estrangeira desejável a todas as forças opositoras aos regimes absolutistas, que governavam a maioria dos países europeus. De acordo com Alexis de Tocqueville, "todas as revoluções civis e políticas tiveram uma pátria e nela se fecharam. A Revolução Francesa não teve um território próprio, mais do que isso, teve por efeito por assim dizer apagar do mapa todas as antigas fronteiras." Ela foi uma revolução ideológica que dividiu os homens em relação às leis, às tradições, aos modos e costumes da política e do comércio. Segundo Tocqueville a Revolução Francesa formou "acima de todas as nacionalidades uma pátria intelectual comum da qual homens de todas as nações podiam tornar-se cidadãos." 30 É possível inferir que foram essas características peculiares que tornaram uma revolta das classes menos favorecidas da população francesa o elemento gerador de um império de dimensões continentais. Pode-se, por outro lado, argumentar que o ambiente sócio-cultural da segunda metade do Setecentos, ansioso por mudanças e novidades de todo tipo, adubou o solo para a grande colheita revolucionária do final do século XVIII, não só na Europa como nas Américas.

Em nossa hipótese interpretativa a Revolução Francesa foi uma tentativa de levar à prática as ideias iluministas. Em termos teóricos ela é filha das discussões travadas em diversos círculos intelectuais europeus, ao longo do século XVIII, a propósito da eficácia do Estado em proporcionar melhores condições de vida. $\mathrm{Na}$ visão de Isaiah Berlin, a Revolução Francesa "estava fundamentada na noção das verdades eternas, dadas as faculdades da Razão, com a qual todos os homens estão dotados." 31 O que se buscava, teoricamente, era o Estado perfeito, a sociedade estática e harmoniosa ou o que disso mais de aproximasse, dada a imperfeição das instituições humanas. Seria então razoável supormos que grande parte dos efeitos duradouros das mudanças introduzidas pelos governos revolucionários na Europa entre 1789 e 1815 está ligada a esse suporte ideológico, que produziu políticas eficazes no sentido de reorganizar as estruturas sociais de forma a adequá-las aos novos processos produtivos. Ao abolir uma série de leis,

\footnotetext{
${ }^{30}$ Alexis de Tocqueville. O Antigo Regime e a Revolução, p. 59

${ }^{31}$ Isaiah Berlin. Vico e Herder, p. 188
} 
tais como a servidão voluntária (corveia) e a pena de morte, e introduzir o sistema de votação nas constituições de várias regiões sob ocupação francesa, houve uma ampliação da participação política que não pôde ser revertida, apesar das tentativas, na época da Restauração.

No ano de 1790, o filósofo inglês Edmund Burke (1729-1797) afirmava "considerando-se bem as circunstâncias, a Revolução Francesa é a mais extraordinária que o mundo já viu. (...) Diante do espetáculo dessa monstruosa tragicomédia os mais opostos sentimentos se sucedem em nós e, algumas vezes, se confundem." ${ }^{32}$ Ao final da década de 1790, o pensador e crítico alemão Friedrich Schlegel (1772-1820) dizia "a Revolução Francesa pode ser considerada o maior e mais notável fenômeno da história dos Estados, um terremoto quase universal, um imenso dilúvio no mundo político; ou o protótipo das revoluções, a revolução pura e simples." 33 Essas opiniões coevas traduzem o espanto dos intelectuais europeus, de diversos quadrantes, diante do ambiente de convulsão que dominou o cotidiano dos povos na década final do século XVIII e nos primeiros três lustros do século XIX. A ascensão e a queda da Napoleão Bonaparte, assim como os resultados políticos do desmembramento do império por ele arquitetado e conquistado, prolongaram a influência da Revolução Francesa no continente europeu até a década de 1830.

Voltando nosso olhar para o cenário cultural dessa época concordamos com Gilles Tiber quando ele afirma "a Revolução Francesa foi um catalisador, um detonador. Deu unidade de tom aos diversos sentimentos de individualismo e de revolta que se tinham manifestado na segunda metade do século XVIII, e que se exprimiam nas diversas literaturas românticas." 34 O período de convulsões revolucionárias que se estendeu de 1789 a 1815 foi marcado por guerras, sublevações, perseguições políticas e incertezas econômicas. Seria razoável supor que a produção intelectual (assim como a produção artística) desses anos foi um reflexo desse ambiente um tanto quanto caótico. Tudo deveria ser revolucionado: o Drama, o Romance, a Poesia, a Crítica, a História, a Filosofia. Para Francis Claudon, "a temática e a poética do Romantismo se fundem em grande parte na Revolução." ${ }^{35}$ É como se pudéssemos entender que o ímpeto de uma nova ordem,

\footnotetext{
${ }^{32}$ Edmund Burke. Reflexões sobre a Revolução em França, p. 52

${ }^{33}$ Friedrich Schlegel. O Dialeto dos Fragmentos, p. 134

${ }^{34}$ Gilles Tiber. "O Romantismo e a Revolução Francesa" in Francis Claudon (org). Enciclopédia do Romantismo, p. 29

${ }^{35}$ Francis Claudon. "O Romantismo". Idem, p. 19
} 
aquela trazida pela Revolução e posteriormente pelo Império, varreu tal qual um vendaval o pensamento europeu. Na verdade, a morte do Antigo Regime assinalou o fim do Classicismo, que Ihe dava sustentação ideológica. No mundo que se esboçava nos primeiros anos do século XIX, as alegorias mitológicas e as elegias aos grandes herois de todos os tempos esvaziavam-se de conteúdo. Segundo Karlheinz Roschitz, "a Burguesia queria ver materializado o seu próprio ser, o seu devir político e social, a sua história." Não havia mais interesse nos deuses e herois da Antiguidade, e agora "as personalidades históricas investiam o primeiro plano da cena: os grandes capitães, os monarcas e os artistas." ${ }^{36}$ Dentro de nossa hipótese interpretativa inferimos que a consolidação dos ideais burgueses (expressos politicamente pela Revolução Francesa e economicamente possibilitados pela Revolução Industrial) demoliu o suntuoso edifício do Classicismo, que vinha mantendo-se de pé desde a Renascença. As mudanças ocorridas na segunda metade do século XVIII não puderam ser absorvidas pelo Antigo Regime, já que as novas propostas de organização social e de ordenamento econômico não conseguiram prosperar no solo infértil de uma ordem política que se tornara anacrônica. Refletindo sobre transformações dessa época Peter Gay afirmou "a Revolução Francesa e a Revolução Industrial, acompanhadas e seguidas de turbulências igualmente profundas nas ciências humanas, abalaram a maior parte das estruturas de crença e de autoridade, chegando a demolir algumas delas para sempre." ${ }^{37}$ Em vista do aqui exposto, seria razoável supor que o Artista deveria ser, antes de tudo, um homem do seu tempo, comprometido em mostrar as contradições da sociedade em que ele vivia, uma vez que a expressão artística deixava de ser um meio de aprendizagem e de deleite para tornar-se um veículo de difusão das ideias que turbilhonavam aqueles tempos. O Classicismo cedia lugar ao Romantismo.

Escrevendo de Perúgia no dia 25 de outubro de 1786, Goethe observou: "Em tudo quanto envolve a Mecânica e a Técnica, que são elementos sobre os quais repousa um modo de vida mais confortável e tranquilo, esta Itália, tão favorecida

\footnotetext{
${ }^{36}$ Karlheinz Roschitz. "A Escultura”. Idem, p. 118

${ }^{37}$ Peter Gay. A Experiência Burguesa da Rainha Vitória a Freud, volume 1, A Educação dos Sentidos, p. 44
} 
pela Natureza, ficou para trás de todos os demais países." 38 Podemos entender essas palavras como um diagnóstico do atraso econômico e da consequente pobreza do povo peninsular. Eric J. Hobsbawn lembra "doenças endêmicas, como a malária restringiam a colonização em muitas áreas, como o sul da Itália, onde as planícies do litoral só foram gradualmente povoadas durante o século XIX." A Itália era uma região muito pouco desenvolvida, apresentando problemas climáticos que dificultavam a criação de rebanhos, despovoando vastas áreas como as planícies da Apúlia, por exemplo. Hobsbawn chama nossa atenção para várias gravuras de época que mostram o sul da Península como "um espaço vazio infestado de malária, com algumas ruínas, algumas cabeças de gado e o estranho e pitoresco bandoleiro." ${ }^{39}$ Acrescentaríamos que nada existe de mais romântico do que ruínas antigas em paisagens sombrias e desoladas onde a Morte ou o Diabo estão sempre de tocaia. A explicação para o atraso econômico italiano, na opinião de William Otto Henderson, é que "à Itália faltavam as fontes de carvão e de minério de ferro necessárias para um país se tornar industrializado no século XIX." $40 \mathrm{E}$ o fato de 0 território peninsular, depois de 1815, estar novamente dividido, desta vez em nove Estados, alguns sob governos estrangeiros, não ajudava a solução desses problemas.

De acordo com Paolo Rossi, "as ideias revolucionárias e a Revolução chegaram à Itália na ponta das baionetas." " 41 ̀̀ guisa de esclarecimento diremos que o historiador se refere às invasões francesas de 1796 e 1805, ambas capitaneadas por Napoleão Bonaparte. Segundo Eric J. Hobsbawn, "na Itália, o predomínio do lluminismo e da Maçonaria tornou a Revolução imensamente popular entre os cidadãos instruídos." 42 É razoável supor que o sucesso dessas invasões foi em grande medida devido a essa camada de "cidadãos instruídos", que formavam uma insipiente burguesia local e viam na vitória das tropas invasoras a chance de garantir uma ordem política mais atenta aos seus interesses. Em termos práticos, como lembra Hobsbawn, esses filo-jacobinos foram "um auxilio para a conquista francesa e uma fonte de administradores politicamente confiáveis para os territórios

\footnotetext{
${ }^{38}$ Goethe. Viagem à Itália: 1786-1788, p. 140

${ }^{39}$ Eric J. Hobsbawn. Op cit, p. 24

${ }^{40}$ William Otto Henderson. A Revolução Industrial 1780-1914, p. 12

${ }^{41}$ Paolo Rossi. Storia d'Italia dal 1500 al 1815, p. 284 (nossa tradução)

${ }^{42}$ Eric J. Hobsbawn. Op cit, p. 99
} 
conquistados." 43 De tudo isso podemos inferir duas consequências: que a permanência do Reino da Itália e do Reino de Nápoles foi possível graças à enorme colaboração de italianos "politicamente confiáveis"; e que a continuação desses dois reinos como unidades políticas independentes do Império como desejavam muitos "cidadãos instruídos" e foi ardentemente tentada seja por Eugênio Beauharnais (Vice-rei da Itália), seja por Joaquim Murat (Rei de Nápoles) era impossível após a derrota de Napoleão em Waterloo.

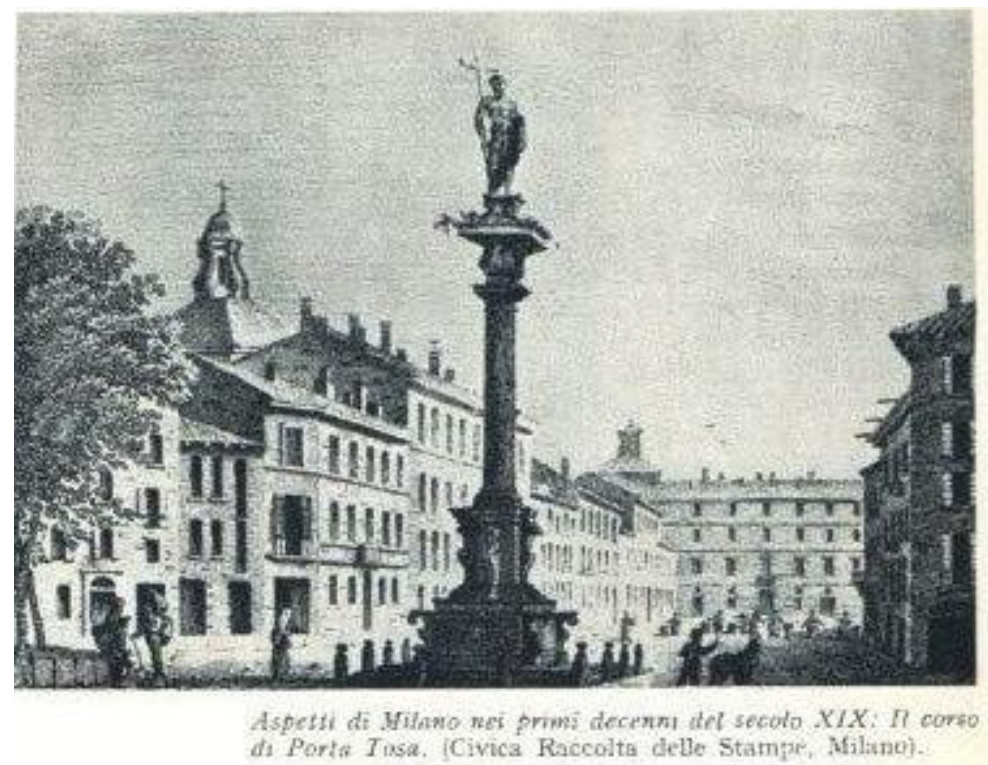

Vista de Milão nas primeiras décadas do século XIX: rua da Porta Tosa (in Cesare Spellanzon. Storia del Risorgimento e dell'unità d'Italia, p.619)

Toda a agitação política que convulsionou o território peninsular no início do século XIX terminou de forma um tanto quanto melancólica após o Congresso de Viena em 1815. Nas palavras do historiador (e autor de um dos melhores e mais completos estudos sobre esse período) Cesare Spellanzon,

\begin{abstract}
Esta é a Itália do pós-guerra: os votos unitários, os sonhos de independência, as aspirações liberais, tudo foi sufocado pela restauração legitimista que desejou dividir e subdividir a Península segundo uma concepção atrasada das necessidades nacionais para corresponder à ambição da Áustria e satisfazer as exigências das famílias principescas e reais que reclamavam os seus antigos tronos.
\end{abstract}

Após 1815 a Itália passou a abrigar vários Estados, todos dependentes em diferentes graus do governo austríaco. O Trentino, a Lombardia, a ex-República de

\footnotetext{
${ }^{43}$ Idem, p. 120

${ }^{44}$ Cesare Spellanzon. Storia del Risorgimento e dell'unità d'Italia, volume primo, Dalle origini ai moti del 1820-21 e al Congresso di Verona, p. 692 (nossa tradução)
} 
Veneza e a Valtellina foram reunidos no Reino Lombardo-Vêneto, anexado ao império dos Habsburgos; o Grão-Ducado da Toscana foi restituído a Fernando III de Lorena; o Ducado de Modena dado a Francisco IV de Áustria-Este; o Ducado de Parma foi entregue a Maria Luísa, filha do imperador da Áustria e viúva de Napoleão Bonaparte, com a cláusula (acordo firmado em 1817) que com o falecimento da Duquesa o território seria devolvido aos Bourbon de Parma, que foram provisoriamente colocados no governo da ex-República de Lucca, transformada em Ducado. O Reino de Nápoles, após a queda de Joaquim Murat, foi restituído a Fernando IV de Bourbon, que depois de assinar um tratado de permanente aliança defensiva com a Áustria (12 de junho de 1815) assumiu o título de Rei das Duas Sicílias com o nome de Fernando I. Para garantir sua influência sobre essas novas unidades políticas a Áustria arrogou-se o direito de manter tropas aquarteladas nas cidades de Piacenza (no Ducado de Parma), de Ferrara e de Comacchio (nos Estados Pontifícios). O único Estado realmente independente era o Piemonte, governado por Vitor Emanuel I, que teve reconhecido no Congresso de Viena o seu direito de posse sobre a ilha da Sardenha, além de incorporar a ex-República de Gênova. ${ }^{45}$ À guisa de esclarecimento diremos que a situação política variava enormemente de Estado para Estado: alguns eram mais liberais do que outros; havia os que possuíam uma aristocracia atuante e influente; assim como existiam lugares onde os burgueses conspiravam em sociedades secretas, mais ou menos toleradas dependendo da índole do governante e da eficiência da polícia. Mas uma coisa é certa: a ameaça revolucionária será uma constante na Península de 1815 até o Ressurgimento, e nesse caldo de tensão política será forjado o movimento romântico italiano.

Para nós é muitas vezes difícil compreender essa época de profundas mudanças por que somos filhos das transformações nela operadas. A Era Romântica foi um período histórico estranho, de homens extremados e de acontecimentos extraordinários. Segundo o diplomata e historiador Manuel de

\footnotetext{
${ }^{45}$ Stuart J. Woolf. "La storia politica e sociale" in Ruggiero Romano e Corrado Vivanti (org). Storia d'Italia, volume terzo, Dal primo Settecento all'Unità. $O$ autor oferece uma análise dessas unidades políticas a partir da p. 244
} 
Oliveira Lima (1867-1928), "era então o tempo dos grandes planos, das grandes quimeras e das grandes partidas, quando se jogavam coroas, povos e raças sobre o tabuleiro político." ${ }^{46}$ Se assim foram os Anos Românticos é razoável supor que seus coevos tenham propagado credos extremistas, buscado com sofreguidão novas formas de viver e também colocando em discussão os princípios formadores do mundo que os rodeava.

Uma característica marcante da Era Romântica foi a juventude da população desse período histórico. Houve um grande incremento demográfico que povoou com moços e moças os países europeus. Existia trabalho, não havia escassez de alimentos e também não aconteceram epidemias devastadoras. Aos que viveram essa época foi dada a oportunidade de sonhar um mundo diferente, de lutar por seus ideais e de acreditar na colheita dos frutos desse idealismo. Afinal de contas essa é a época da Revolução Industrial e seus grandes avanços tecnológicos, que mudaram o Mundo; da Revolução Americana, que criou a primeira grande república federativa e democrática da História; da Revolução Francesa, que guilhotinou um rei e aboliu os privilégios da classe aristocrática; do Império Napoleônico, que abalou a correlação de forças políticas e militares entre as grandes potências da Europa; da revolta de São Domingos, origem do primeiro país negro e independente das Américas, o Haiti; dos movimentos de independência das colônias espanholas nas Américas; e da formação de um vasto império na América portuguesa. Tudo isso foi possível, em nossa hipótese interpretativa, porque os jovens são por natureza inquietos, adeptos de mudanças e fortes o bastante para transformarem seu entusiasmo em ação revolucionária. Tal era o espírito daquela época, culturalmente elaborado pela escola romântica.

A Revolução Industrial marcou de maneira indelével os Anos Românticos. Ela mudou as relações de comércio, transformou as formas de produção, encurtou distâncias, criou grandes concentrações urbanas e gerou uma nova classe social: a Burguesia. Quando focamos a produção intelectual e artística desse período notamos que a passagem do Mercantilismo ao Capitalismo está pontuada por um novo elemento: o Mercado. Se nos tempos do Antigo Regime o artista é o protegido ou o agregado de um rei ou de um nobre que lhe encomendava uma pintura ou uma escultura, patrocinava a publicação de um livro ou mantinha uma companhia de

\footnotetext{
${ }^{46}$ Manuel de Oliveira Lima. Dom João VI no Brasil, p. 230
} 
teatro, a partir da segunda metade do século XVIII o público consumidor de bens culturais amplia-se de forma significativa. Quadros, livros e espetáculos teatrais tornam-se mercadorias acessíveis a quem possa pagar por elas, e por isso seu consumo deixa de ser uma exclusividade da Aristocracia. ${ }^{47}$ Seria razoável supor que essa ampliação do público gerou uma demanda por temas diversos daqueles de inspiração mitológica tão ao gosto dos aristocratas beneficiários do Antigo Regime, o que provocou a busca por novos paradigmas culturais para atender as necessidades estéticas de uma classe diferente de consumidores. Os românticos, ao rejeitarem as imposições das academias (que tornavam obrigatórios os temas de inspiração greco-romana) faziam-se porta-vozes desse público que desejava ser representado pela produção artística. A comédia de costumes e as histórias amorosas difundidas nos folhetins, tão significativas da criação artístico-literária do Romantismo, foram a resposta dada pelos escritores da virada do século XVIII a essa nova classe social que comprava livros e lotava teatros. Em resumo, a Revolução Industrial, ao promover um aumento geral (embora desigual) da Riqueza, criou um novo público consumidor de bens culturais que por sua vez impôs o seu gosto e transformou a produção intelectual da época. $\mathrm{Na}$ segunda metade do século XVIII, mais rapidamente em algumas regiões do que em outras, iniciou-se a passagem do Mercantilismo ao Capitalismo, em termos econômicos, e do Classicismo ao Romantismo, em termos culturais.

Já foi dito que a Revolução Francesa é a revolução das revoluções; a revolução total, absoluta. As mudanças que ela introduziu até hoje repercutem na nossa vida cotidiana: os direitos dos cidadãos, a igualdade de todos perante à Lei e a ampla liberdade de expressão e de manifestação do pensamento individual são heranças daqueles tempos de que ainda desfrutamos. Muito embora a Revolução Francesa seja filha dos ideais propagados pelo lluminismo, ou seja, da crença no poder transformador da Razão que alimentava as discussões nos círculos intelectuais do Ocidente durante boa parte do século XVIII, o seu desenrolar acabou sepultando a época histórica que a gerou. Foi no cenário de guerras, instabilidade política e de mudanças profundas na maneira de viver e de perceber o mundo ao redor que forjou-se uma nova cultura, cujo paradigma é a rejeição às instituições culturais do Antigo Regime. Aos cânones da Academia sobrepõe-se a capacidade

\footnotetext{
${ }^{47}$ Para uma análise mais aprofundada desse tema ver Jean Duvignaud. Sociologia do Comediante, em especial o capítulo 2 ("O papel do ator nas sociedades liberais")
} 
inventiva do Gênio, capaz de criar aquilo que ainda não foi visto, de expressar aquilo que ainda não foi pensado. Na Cultura, assim como na Economia e na Política, as barreiras serão rompidas e os limites serão ampliados: quebra-se a unidade clássica em nome de um leque maior de opções e a Arte, longe de representar um ideal frio e distante, irá doravante buscar inspiração nas agruras e dificuldades da existência comum, abandonando os cenários da Antiguidade greco-romana pelas cenas da vida europeia a partir do Medioevo. É certo que essas concepções estéticas foram geradas ao longo da segunda metade do Setecentos, porém elas foram catalisadas na Revolução Francesa, que construiu um ambiente propício à disseminação desse conjunto de ideias que ficou conhecido como Romantismo.

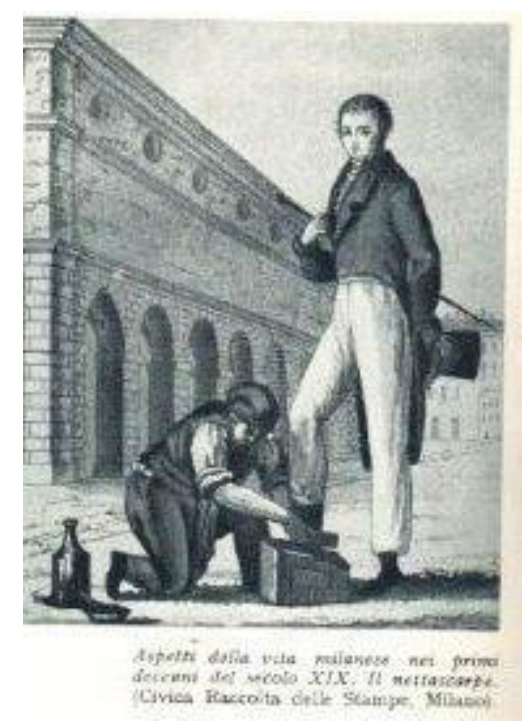

Cenas da vida milanesa nas primeiras décadas do século XIX: o engraxate (in Cesare Spellanzon. Storia del Risorgimento e dell'unità d'Italia, p.622)

O movimento romântico italiano foi forjado nas desilusões provocadas pela maneira como as potências vencedoras da guerra contra Napoleão Bonaparte dividiram a Península. É preciso considerar que muitos oficiais de origem italiana haviam obtido suas divisas nas tropas napoleônicas, que contaram com batalhões formados por peninsulares na malfadada invasão à Rússia. ${ }^{48}$ Além disso, a geração nascida na década de 1780 chegava à maturidade convencida de que a única solução para os problemas italianos era a reunificação da Itália. Mas, ao contrário dos filo-jacobinos do final do século XVIII, essa geração também estava convicta que a reunificação teria de ser obra dos italianos e não de estrangeiros

\footnotetext{
${ }^{48}$ Giorgio Candeloro. Storia dell'Italia moderna, volume I, Le origini del Risorgimento (1700-1815), pp 318-319
} 
poderosos, simpáticos à causa nacional italiana, como fora Bonaparte. ${ }^{49} \mathrm{O}$ grande legado napoleônico foi a unificação dos diversos Estados peninsulares em dois reinos: o Reino da Itália e o Reino de Nápoles. Apesar das dificuldades administrativas e dos problemas políticos criados por uma forte resistência à ocupação francesa (especialmente no Reino de Nápoles) os italianos experimentaram o comércio livre de aduanas por vastas áreas, o relaxamento da servidão nos campos e a possibilidade de fazer carreira em um exército com amplos recursos bélicos. Essa reunião de militares desmobilizados e de funcionários públicos (ex-servidores da administração francesa) desempregados estimulou, entre as classes superiores, um sentimento nacionalista que foi se exacerbando na medida em que a Áustria, com o apoio das outras potências da Santa Aliança, procurava reprimir toda e qualquer dissidência dentro dos limites de seu império. ${ }^{50}$ O grosso da repressão política não recaiu sobre as camadas menos favorecidas da população (na maioria incapazes de exprimir seus anseios), mas sobre a nobreza e a intelectualidade, que se organizavam para lutar pelo ideal de uma Itália para os italianos.

Assim foram os Anos Românticos. Não surpreende, portanto, que seus contemporâneos tenham pregado credos extremistas, buscado com sofreguidão novas formas de viver e também colocado em discussão os princípios formadores do mundo que os rodeava. De acordo com Giovanni Macchia, "guerras, desastres, cidades incendiadas, crueldade, sadismo, desvios eróticos, virtudes incorruptíveis e vinganças refinadas: dentro desse cenário de violências, de heroísmos, de libertações, de sacrifícios e de ideologias se constrói, sem renegar o Passado, uma nova sociedade." E dentro dessa realidade tão conturbada, ainda segundo o crítico, "a Literatura passa a ser responsável por um destino coletivo; passa a ser situada na região dos destinos humanos." 51 É como se pudéssemos entender que a cultura ocidental deixava de ser clássica para tornar-se romântica.

\footnotetext{
${ }^{49}$ Paolo Rossi. Op cit, p. 283 e seguintes

${ }^{50}$ Giorgio Candeloro. Op cit, p. 293

${ }^{51}$ Giovanni Macchia. "Origini europee del Romanticismo" in Emilio Cecchi e Natalino Sapegno (org).

Storia della Letteratura italiana, volume settimo, L’Ottocento, p. 387 (nossa tradução)
} 


\section{CAPÍTULO 2 ROMANTISMO E CLASSICISMO}

\subsection{0 conceito}

Desde o início do século XIX a palavra Romantismo é um termo comum na cultura ocidental. Ele aparece em todas as línguas europeias e a amplitude de sua significação é um desafio a ser enfrentado por quem se dedica a estudar o desenvolvimento da Estética e da Arte no Ocidente. Paulo Prado (1869-1943), o modernista, autor de Retrato do Brasil, afirmava, em seu livro de 1928, "como expressão dinâmica do espírito humano o Romantismo é um fenômeno extenso e complexo. (...) Os volumes da formidável bibliografia que dele se ocupa encheriam as estantes de uma biblioteca." Prado busca as origens românticas no platonismo grego, passando pelo neoplatonismo de Alexandria, indo até a Idade Média, adentrando a Renascença e internando-se pela Reforma; uma viagem através dos séculos. Segundo o autor, "filosofia, artes, sistemas políticos, novos modos de sensibilidade, a cultura enfim, e a própria civilização ocidental" de maneira direta e indireta sofreram a influência da visão romântica. No entender do modernista, muito embora seja considerado por vários autores como uma antítese do Classicismo, ou seja, das noções de ordem e de clareza que pautavam o discurso estético após a Renascença, "o Romantismo é simplesmente uma atitude ou modo de ser de uma época turva e revoltada reagindo contra as antigas disciplinas que insistiam sem resultado em abafar a ânsia de independência, tão peculiar às multidões libertárias do fim do século XVIII." Ainda seguindo a trilha de Paulo Prado, teríamos que diferenciar o romantismo do sentimento do romantismo da inteligência: "um é sinônimo de lirismo e de pessimismo; o segundo, ao contrário, é uma afirmação de generosidade, de ardor, de fé no inesgotável poder do espírito humano." ${ }^{2}$ De tudo isso é possível inferir que a complexidade do fenômeno sócio-cultural denominado Romantismo se justifica pela sua vasta influência na civilização ocidental. De maneira geral o influxo das ideias românticas poderia ser explicado pelas alternâncias entre Razão e Sentimento, Clareza e Abstração, Universal e Particular que teriam ocorrido em diversos períodos ao longo da história intelectual do Ocidente.

\footnotetext{
${ }^{52}$ Paulo Prado. Retrato do Brasil, pp 164-165
} 
Mario Praz, em seu estudo sobre as ideias românticas, alerta que, no campo das artes, "aproximações como barroco, romântico, decadente, etc. tiveram origem em determinadas revoluções da sensibilidade, e não convém destacá-las das suas bases históricas para aplicá-las generosamente aos artistas mais disparatados, segundo o capricho mais extravagante dos críticos." ${ }^{53}$ É como se pudéssemos entender que a obra de arte é um testemunho da capacidade individual de seu realizador em expressar a realidade na qual ele se insere (ou não se insere, como é o caso de muitos românticos) e assim compor um mosaico no qual a harmonia das peças seria alcançada pela afinidade dos temas e pelo tratamento a eles dispensado. Para Gerd Borheim, "o Romantismo é, fundamentalmente, um movimento cultural, inserido em um determinado momento da História, e somente a partir dessa situação pode ser ele compreendido." 54 É possível inferir então que devemos ser cautelosos com o uso indiscriminado da palavra romântico, pois ela se refere a um conjunto de realizações intelectuais e artísticas que está relacionado a um contexto histórico determinado. Segundo Francis Claudon, na história da cultura ocidental, "deu-se o nome de Romantismo ao vasto movimento que, a partir do século XVIII, pôs em questão o Humanismo e a Razão toda-poderosa, correndo o risco de abalar os velhos alicerces da civilização clássica." A bem da verdade o influxo romântico não respeitou fronteiras e varreu, tal qual uma imensa onda, amplos territórios. O Romantismo desempenhou, no entender de Claudon, "um papel primordial na vida do espírito, na filosofia, na sociedade, nos costumes, nas revoluções sociais e políticas." 55 Seria razoável supor a amplitude territorial e a vastidão das faculdades do Espírito alcançadas pelas transformações românticas um empecilho metodológico ao seu estudo e principalmente à sua definição. Essa dificuldade realmente existe, e por isso preferimos falar em movimentos românticos (o italiano, o brasileiro, o francês, o inglês, etc.) por entendermos que ao valorizar o elemento local a escola romântica absorveu peculiaridades específicas das diferentes sociedades nas quais se desenvolveu.

Escrevendo em 1863, anos após a passagem da vaga romântica, Ferdinand Wolf (1796-1866), ele próprio um contemporâneo do movimento, afirmava "a Europa não foi somente remoçada do ponto de vista político pelo batismo de sangue da

\footnotetext{
${ }^{53}$ Mario Praz. A Carne, a Morte e o Diabo na Literatura Romântica, p. 28

${ }^{54}$ Gerd Borheim. "Filosofia do Romantismo" in J. Guinsburg (org). O Romantismo, p. 77

${ }^{55}$ Francis Claudon. "O Romantismo" in Francis Claudon (org). Enciclopédia do Romantismo, p. 7
} 
Revolução Francesa; também o foi, literariamente, pela confirmação do princípio popular, da fé numa espontaneidade natural e nacional proveniente da Alemanha." Na opinião do filólogo e historiador austríaco a principal contribuição do Romantismo foi o restabelecimento da Espontaneidade na Poesia, uma característica perdida com as restrições estéticas impostas pelas academias. A escrita poética mais espontânea, segundo ele, "fez com que se reconhecesse a todos os povos o direito imprescindível de imprimirem marcas próprias ao seu gênio particular". Para Wolf, "o verdadeiro romantismo não é, com efeito, outra cousa que a expressão do gênio de uma nação, desembaraçado de todos os entraves da convenção." Daí surgiu o nome da nova escola: chamou-se romance, na Idade Média, as línguas vulgares, que se opuseram à língua latina culta. Nos explica o estudioso que no intuito de "restaurar a continuidade de seu desenvolvimento espontâneo e paralisar a influência moderna dos humanistas, dos reformistas, do Classicismo e do Racionalismo, esses mesmos povos tiveram de fazer um passo atrás e beber nas fontes sempre fartas da ldade Média, época brilhante, de desenvolvimento mais conforme o seu gênio." Seria razoável supor que no regresso às suas raízes históricas esses povos passaram a valorizar um patrimônio imaterial que se expressava em canções folclóricas, danças populares, mitos regionais e cenários característicos de cada país. O grande problema do Romantismo, no entender de Wolf, é que tomando como base a estética medieval "excessivamente idealista, comprazendo-se no misticismo e no fantástico" ele perdeu a objetividade. Como resultado disso chamou-se Romantismo, na definição de nosso autor, "nos domínios da Arte e da Poesia, a tudo o que é subjetivo, arbitrário, caprichoso e sem formas determinadas." 56 À guisa de esclarecimento diríamos que na segunda metade do século XIX, época na qual Wolf escreveu seu texto, o conceito de Romantismo estava um tanto quanto expurgado, em uma Europa de monarquias constitucionais e burguesas, de seus ímpetos originariamente revolucionários.

Qual foi a origem do termo Romantismo?

\footnotetext{
${ }^{56}$ Ferdinand Wolf. "O Brasil literário - História da Liberatura Brasileira (capítulo XIV)" in Guilhermino César (seleção e apresentação). Historiadores e críticos do Romantismo, volume 1, A Contribuição Europeia: Crítica e História Literária, p. 171
} 
De acordo com Sílvio Elia, "a base do adjetivo romântico é o advérbio Romanice, do latim popular, que significa 'à maneira dos romanos". Esse advérbio deu origem à palavra francesa Romanz, que depois transformou-se em Romant e finalmente assumiu a forma Roman, no século XVI. Mas essa palavra (e suas variantes) se referiu a coisas diversas através dos tempos, segundo Elia: "no século XII designa qualquer narrativa do povo, em oposição ao Latim; no século XIV o sentido se especializa para romances de aventuras, em verso; no século XV o sentido se estende aos romances de cavalaria, em prosa; só do século XVII em diante foi que tomou o sentido que hoje tem." É possível inferir dessa explicação filológica que o termo Roman sempre esteve associado a estórias do povo, diferentes das obras clássicas de inspiração greco-romana: eram aventuras de cavaleiros, relatos de peregrinos e milagres de santos que deleitavam as audiências dos menestréis medievais e dos poetas populares da Renascença e do Barroco. Para Sílvio Elia, "a evolução semântica do inglês romantic está nas raízes do termo romantismo. O ponto de partida foi uma aplicação do epíteto à Natureza, para indicar certo sentimento despertado em nós diante de determinadas paisagens." ${ }^{57}$ É interessante notar que romântico, no início, foi um termo ligado às imagens e não às palavras.

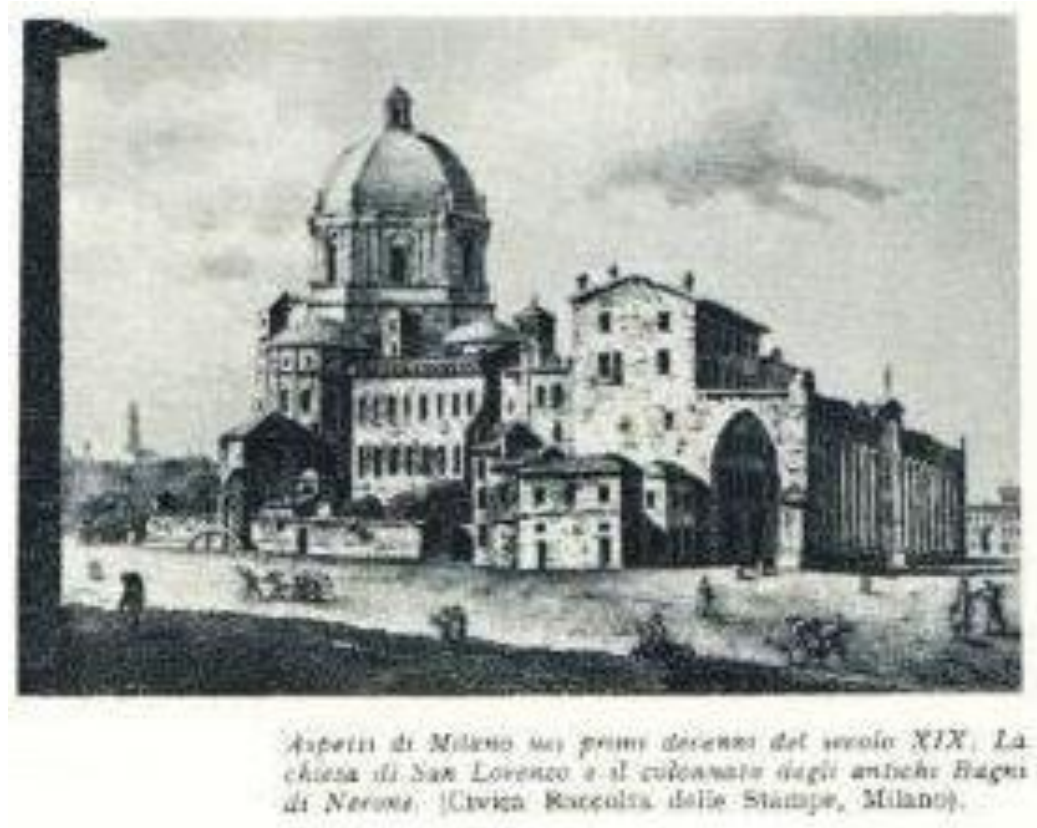

Vista de Milão nas primeiras décadas do século XIX: Igreja de São Lourenço e o conjunto de colunas dos antigos Banhos de Nero (in Cesare Spellanzon. Storia del Risorgimento e dell'unità d'Italia, p. 623)

${ }^{57}$ Sílvio Elia. "Romantismo e Linguística" in J. Guinsburg (org). Op cit, pp 114-115 
O adjetivo romântico migrou da Pintura para a Literatura. Segundo Carla Appolonio, "esse termo, que na verdade é encontrado pela primeira vez na Inglaterra na metade do século XVII, deriva da antiga palavra francesa romaunt, que significa conto ou romance, (...)." Com o tempo essa palavra passou a designar também certas paisagens que evocavam, no olhar da época, "o fantástico, o estranho e o fabuloso" que eram usualmente encontrados nos romances. A autora acrescenta "com esses significados o termo passa a ser usado também na Alemanha, onde começa-se a preferir a palavra romantish à antiga romanhaft; e na França, onde porém só no final dos Setecentos se distingue romantique de romanesque." Mas nessas andanças o vocábulo em questão parece ter adquirido outro significado: denominava o sentimento algo nostálgico, algo ameaçador que lugares ermos e solitários provocavam nas pessoas que por eles transitavam. Appolonio explica, "se o termo é usado, por um lado, para coisas de romances, por ouro significa coisas relativas à Natureza, e por fim diz-se de certas gradações de sentimento." 58 Acrescentaríamos que no início do século XVIII empregava-se o adjetivo romântico na designação de pinturas que retratavam paisagens ermas e desoladas, tais como as charnecas escocesas. A luz desses quadros era difusa, compondo a imagem de um céu nublado, que se estendia sobre ruínas de castelos ou de igrejas medievais. Essas obras contrastavam com pinturas mais alegres, de campos floridos $\mathrm{e}$ ensolarados, às quais dava-se o nome de clássicas. À guisa de esclarecimento gostaríamos de lembrar que os livros góticos de Ann Radcliffe, Horace Walpole e William Beckford estão repletos de descrições de lugares onde a Natureza frequentemente provoca arrepios de pavor. São ruínas de monastérios ou de cemitérios localizados em montanhas batidas pelo vento inclemente, ou castelos distantes habitados por fantasmas, e ainda florestas espessas e selvagens que acolhem ladrões e feiticeiras. Em resumo, paisagens sombrias são românticas e paisagens luminosas são clássicas, o que nos dá uma série de pistas sobre as propostas da nova escola.

\footnotetext{
${ }^{58}$ Carla Appolonio. Romantico: storia e fortuna di una parola, pp 74-75 (nossa tradução)
} 
René Welleck pondera "por mais que se possa justificar a insatisfação de alguns estudiosos com os múltiplos significados do termo romantismo, parece impossível negar que nos confrontamos aqui com os problemas causados pela dissolução do Neoclassicismo e a sua substituição por novas e diferentes teorias." 59 Seria razoável supor que o caráter nacionalista, voltado para as manifestações da cultura popular em busca de novos paradigmas para a produção artística, que impregnou a escola romântica desde os seus primórdios criou movimentos culturais de matrizes variadas, tanto quanto os povos que inspiravam essas manifestações. É preciso ter em mente que a cultura de origem romântica se contrapunha à universalidade da cultura de matriz clássica (greco-romana). Bruno Kiefer comenta "como todo movimento estético o Romantismo possui contradições internas, aspectos regressivos, inovações que nem sempre se afirmam, de saída, com plenitude, linhas de transição gradativa ao lado de fenômenos eruptivos. Além disso, mais do que em todas as épocas anteriores, o Romantismo apresenta uma multiplicidade estilística desconcertante." ${ }^{60} \mathrm{O}$ fio condutor desta pesquisa toma por base as características comuns aos diferentes movimentos românticos (o brasileiro, o italiano, o alemão, o francês, etc.) que desenvolveram um material autóctone preservando, contudo, certas diretrizes. Tais características gerais foram analisadas por Arturo Farinelli em sua obra II Romanticismo nel Mondo Latino, de 1927. Segundo o crítico italiano, são componentes do caráter romântico: a Nacionalidade (o culto à história pátria), o Pessimismo (o gênio incompreendido), o Lúgubre (a atração pela Morte), a Natureza (o isolamento e a solidão românticos), a Melancolia (o amor pela terra distante) e a irmandade entre os gêneros artísticos (a tragicomédia, o teatro lírico). Como bem observou Farinelli, "a história dos contrastes e das oscilações românticos é a história da vida romântica." 61

A busca pela Autenticidade, pela Diferenciação e pela Individualidade que forma a base teórica dos movimentos românticos em geral coloca a questão: considerando-se que o Romantismo perpassa algumas gerações, em países diferentes, em épocas distintas (apesar de cronologicamente próximas) existe uma estética romântica? Franklin Leopoldo e Silva considera "sempre se descobrirá, ao

\footnotetext{
${ }^{59}$ René Welleck. A History of Modern Criticism: 1750-1950, volume I, The Later Eighteenth Century, p. 106 (nossa tradução)

${ }^{60}$ Bruno Kiefer. "O Romantismo na Música" in J. Guinsburg (org). Op cit, p. 206

${ }^{61}$ Arturo Farinelli. II Romanticismo nel Mondo Latino (3 volumes), volume 2, p. 153 (nossa tradução)
} 
lado daquele autor que encarnava certas características que julgamos gerais, um outro que a elas se subtrai, impedindo qualquer superposição entre as individualidades e as épocas." Acrescentaríamos que por trás de toda criação verdadeiramente artística está a personalidade do seu realizador (mais exacerbada, ou mais contida), que no ato criador usualmente não se preocupa se está seguindo esta ou aquela escola. Na maioria das vezes, como lembra Silva, "a História como que produz seus próprios julgamentos e faz triunfar certas tendências que ganham, então, legitimidade, ainda que retrospectivamente." 62 Seria razoável supor que compreender o que legitima certas tendências em detrimento de outras, ou melhor, descobrir o processo sócio-cultural que valida ideias tidas anteriormente como inaceitáveis é a tarefa daqueles que trabalham com a história intelectual.

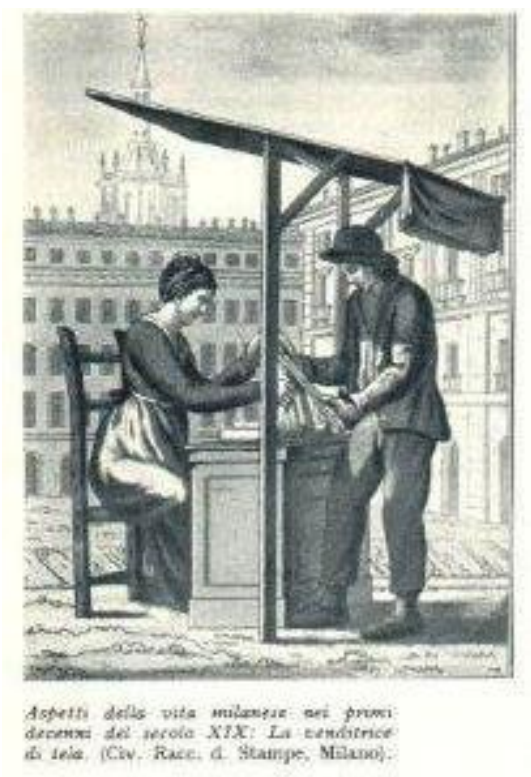

Cenas da vida milanesa nas primeiras décadas do século XIX: a vendedora de telas

(in Cesare Spellanzon. Storia del Risorgimento e dell'unità d'Italia, p. 624)

No entender do crítico italiano Francesco Flora, "quem disser Romantismo (...) fala na verdade de um período que começou no final dos Setecentos e se estendeu pela primeira metade dos Oitocentos, aproximadamente." Em nossa opinião estabelecer marcos cronológicos no campo da história intelectual é algo difícil e complicado. Não podemos dizer com precisão quando o Romantismo começou e quando ele terminou, apenas identificamos características comuns a um conjunto de obras e de artistas coevos a determinados períodos históricos e procuramos alinhá-

\footnotetext{
${ }^{62}$ Franklin Leopoldo e Silva. "O Classicismo em Filosofia" in J. Guinsburg (org). O Classicismo, p. 88
} 
los com certas propostas estéticas em desenvolvimento naqueles períodos. Já na opinião de Flora, "a qualquer nome de poetas que se agrupam sob a bandeira do Romantismo, em qualquer literatura europeia, corresponde uma maneira diferente de pensar e de fazer Poesia, com somente uma premissa comum: contrapor-se à arte e ao pensamento anteriores ou, pelo menos, acreditar-se diferente deles." 63 É possível inferir que essas manifestações de repúdio ao que se supunha velho e ultrapassado variavam de um movimento romântico para outro e justificaram a impressão de falta de unidade estilística (a par da desconcertante variedade de abordagens) que caracterizou a escola. É por isso que tornou-se difícil definir quem ou o quê são na verdade românticos.

Podemos delimitar historicamente o Romantismo? Acreditamos que sim. Segundo o historiador Eric J. Hobsbawn, "em um sentido estrito o Romantismo surgiu como uma tendência consciente e militante das artes, na Grã-Bretanha, França e Alemanha, por volta de 1800 (no final da década da Revolução Francesa), e em uma área bem mais ampla da Europa e da América do Norte depois da batalha de Waterloo". ${ }^{64}$ Nossa hipótese de interpretação aponta que as transformações econômicas e sociais ocorridas na Europa a partir da década de 1770 levaram a um questionamento dos fundamentos teóricos da cultura dominante. Isso levou ao surgimento de manifestações hoje denominadas Pré-Romantismo, como por exemplo o grupo Sturm und Drang, na Alemanha, e o pensamento de Jean Jacques Rousseau, na França. De acordo com René Welleck, o Romantismo, em um sentido amplo, "foi uma revolta contra o Neoclassicismo, o que significou uma rejeição à tradição latina e a adoção de uma visão da Poesia centrada na expressão e na comunicação da Emoção." É como se pudéssemos entender que no alvorecer do século XIX começou a surgir em várias partes do continente europeu uma nova geração de artistas, críticos e pensadores disposta a renovar os paradigmas culturais então em voga. Para Welleck, "essa nova concepção poética surgiu no

\footnotetext{
${ }^{63}$ Francesco Flora. Storia della Letteratura Italiana - L'Ottocento, p. 107 (nossa tradução)

${ }^{64}$ Eric J. Jobsbawn. A Era das Revoluções, p. 280
} 
século XVIII e formou uma vasta maré que inundou todos os países do Ocidente." 65 Mas o que essa "vasta maré" trazia consigo? Na opinião de Eric J. Hobsbawn, "embora não seja absolutamente claro quais eram os propósitos do Romantismo, é bastante evidente o que o Romantismo combatia: o termo médio. Qualquer que seja o seu conteúdo, era um credo extremista." Acrescentaríamos que a nova escola trazia um elemento de insatisfação, de inadequação; vários personagens românticos são jovens que recusam o papel social a eles destinado e buscam o suicídio como uma libertação das estreitas perspectivas que a vida burguesa lhes impunha. Werther (de Goethe) e Jacopo Ortis (de Foscolo) são dois exemplos marcantes dessa tendência. No entender de Hobsbawn, foi em virtude dos românticos adotarem posições extremadas que "Napoleão tornou-se um de seus heróis míticos, como Satã, Shakespeare, o Judeu Errante, e outros pecadores que se colocavam mais além dos limites comuns da vida." Seria razoável supor que a vida desgarrada de Byron e de Shelley, o profundo desprezo pelas maneiras burguesas professado por Flaubert, o suicídio de Kleist e a angústia de Heine serviriam de exemplo às afirmações do historiador britânico. O autor coloca ainda "o elemento demoníaco na acumulação capitalista, a busca ininterrupta e ilimitada de mais, os extremos do luxo, tudo isso encantava os românticos." 66 É possível inferir que uma das diretrizes da nova escola era o culto à Inconformidade, expresso em uma exacerbação da Individualidade: ser romântico significava ser diferente.

A segunda metade do século XVIII assistiu ao advento da Revolução Industrial e sofreu, às vezes de forma dramática, as transformações por ela provocadas: o aumento das populações urbanas; as mudanças nas formas de comércio; o enriquecimento de uma classe de empreendedores; e uma progressiva despersonalização das classes trabalhadoras, confinadas horas e mais horas, diariamente, dentro de fábricas insalubres e de minas rudimentares, tendo que sobreviver do que conseguiam produzir. Não surpreende portanto que, como assinalou John Gassner, "uma das características do Romantismo é a de ter transformado a auto-expressão num fetiche. A revolta contra uma sociedade regida por convenções levou a idealização do Homem como um ser cujo direito primordial

\footnotetext{
${ }^{65}$ René Welleck. A History of Modern Criticism: 1750-1950, volume 2, The Romantic Age, p. 3 (nossa tradução)

${ }^{66}$ Eric J. Hobsbawn. Op cit, p. 281
} 
era expandir suas emoções e realizar sua individualidade de modo privado." ${ }^{67}$ Seria razoável supor que essa postura de insatisfação em relação aos padrões sociais vigentes explica porque vários autores românticos são lembrados e cultuados por suas obras e também por suas personalidades. Talvez o exemplo mais evidente dessa tentativa de viver a vida como se esta fosse uma criação artística, ou seja, viver romanticamente, tenha sido Lord Byron. Mas podemos citar Shelley, Schiller, Castro Alves, Álvares de Azevedo, Leopardi, Kleist e vários outros. Francis Claudon, seguindo essa linha de análise, diz "o Romantismo é, antes de mais, uma questão de temperamento, o resultado de uma individualidade." 68 É como se pudéssemos entender que ocorreu uma inversão de polaridades: se no Classicismo (com suas regras de composição) o foco estava no produto final e não no processo criativo, ou seja, valorizava-se a Obra, no Romantismo o foco passou a ser o processo criativo, ou seja, valorizava-se o Artista.

Friedrich Schlegel (1772-1829), um dos principais teóricos românticos, em um de seus fragmentos críticos, publicado em 1797, declarou "muitos dos romances mais notáveis são um compêndio, uma enciclopédia de toda a vida espiritual de um indivíduo genial." É possível inferir que esses "romances notáveis" seriam na verdade um guia de vida para aqueles que sentiam-se inconformados com o mundo em que viviam; existia então a possibilidade de transpor a barreira entre Arte e Vida, entre Ficção e Realidade. Para Schlegel, "todo o homem que é culto e se cultiva também contém um romance em seu interior." 69 Compreendemos então que o Romantismo é uma maneira de viver, uma postura diante dos fatos, uma forma de posicionamento perante o Mundo. Segundo Francis Claudon, "o Romantismo, no entanto, não é somente um estilo artístico, uma série de transformações sociais e econômicas: constitui uma forma de pensamento." 70 Seria possível supor que é isso que diferencia o Romantismo dos outros movimentos estéticos que o sucederam: a sua profundidade crítico-filosófica.

\footnotetext{
${ }^{67}$ John Gassner. Mestres do Teatro, volume I, p. 387

${ }^{68}$ Francis Claudon. "A Literatura" in Francis Claudon (org). Op cit, p. 187

${ }^{69}$ Friedrich Schlegel. O Dialeto dos Fragmentos, p. 32

${ }^{70}$ Francis Claudon. "O Romantismo" in Francis Claudon (org). Op cit, p. 21
} 
Os românticos, em sua luta contra os padrões culturais vigentes em sua época, foram obrigados a criar novas categorias de análise crítica. Segundo Gerd Borheim, "uma das categorias básicas, fundamentais, que permitem compreender 0 Romantismo é a Unidade. Podemos mesmo dizer que todo o movimento se desdobra sob o signo da Unidade." 71 É possível inferir que o sentimento de alienação e de perda da identidade (ocasionado pelos deslocamentos do campo para as cidades) provocados pela Revolução Industrial e a desagregação de comunidades (resultados da ocupação militar) gerada pelas guerras que assolaram a Europa no tempo do Império Napoleônico contribuíram para destruir a sensação de pertencer a um determinado local, que havia sido a marca das gerações anteriores à Revolução Francesa. O que restou então? O indivíduo fragmentado, perdido numa realidade hostil, cujos parâmetros estão em constante mudança. 0 verdadeiro romântico não consegue desenvolver-se plenamente num mundo de guerras habitado por gente medíocre e gananciosa, cujo materialismo impede a fruição dos sentimentos. A única saída para aqueles que buscam a sua unidade como ser humano é a fuga: através do suicídio, no culto ao Passado, na busca de paraísos artificiais, no cultivo do amor impossível e nas inúmeras maneiras de afirmação da Individualidade. Hegel (1770-1831) considera "o conteúdo substancial das representações de arte romântica é a subjetividade absoluta, a união do espírito com a sua essência, a pacificação da alma, a conciliação de Deus com o Mundo e, portanto, consigo mesmo." 72 Em nossa hipótese interpretativa a necessidade de comunhão com Deus, com o Infinito, é a expressão do desejo de fuga de um mundo cada vez mais voltado para a produção em massa de bens de consumo. Isso explica outra característica romântica: a Religiosidade. Homens pios como Manzoni e Chateaubriand não eram a regra entre os iluministas da primeira metade do século XVIII. Em resumo, havia nessa subjetividade romântica (expressa pela unidade do Homem com Deus) uma recusa, um voltar as costas para a nova ética das relações humanas imposta por uma também nova ordem econômica.

De acordo com Mario Praz, "o romântico exalta o artista que não dá forma material aos seus sonhos, o poeta estático diante da página eternamente branca, 0 músico que escuta os concertos prodigiosos de sua alma sem tentar traduzi-los em notas. É romântico considerar a expressão concreta como decadência, uma

\footnotetext{
${ }^{71}$ Gerd Borheim. Op cit, p. 77

${ }^{72}$ Hegel. Curso de Estética: O Belo na Arte, p. 583
} 
contaminação." ${ }^{73}$ É possível inferir que, para os românticos, só existe uma saída para os homens de talento: não realizar-se como burguês, não trocar por dinheiro seus sonhos e sentimentos. É romântico morrer por um ideal. É romântico não envelhecer, não se degradar. Por isso, o Romantismo celebrará a Juventude, com seus ardores e ímpetos. Para Hegel, “a fantasia romântica exprime-se facilmente por metáforas, porque o exterior aparece-lhe não como uma realidade adequada, mas como desempenhando um papel totalmente secundário ao lado da subjetividade recluída em si mesma." É como se pudéssemos entender que o artista romântico não expressa necessariamente o mundo ao seu redor, mas cria um universo à parte, com seus próprios valores. Ainda segundo Hegel, "preencher este exterior, aparentemente inadequado, de sentimentos mais ou menos profundos, de particularidades perceptíveis, animá-lo pela graça de combinações variadas, é uma tendência a que o poeta romântico jamais pôde resistir e a que a poesia romântica deve a maior parte de suas invenções e descobertas." 74 Seria razoável supor que o romântico sente-se apartado do Mundo e em confronto com a realidade que o cerca, mas percebe que sua missão é temperar com seus sentimentos, expressos por seu talento, a aridez do ambiente no qual ele está inserido. Por isso o Romantismo foi profuso em metáforas ricas de novos conteúdos e de novas significações. O norte americano H. P. Lovecraft (1890-1937), conhecido autor de histórias de terror, em um ensaio escrito em 1927, definiu o "sentimento romântico - a era do gosto pela Natureza, pelo brilhantismo dos tempos passados, cenários exóticos, feitos audazes e maravilhas incríveis." 75 Em nossa hipótese de interpretação tudo isso significa uma recusa aos padrões sociais vigentes, recusa essa manifestada em vários níveis: do individual ao coletivo, da revolta poética à ação política revolucionária, da religiosidade exacerbada à crença num mundo mais livre, mais igualitário e mais fraterno.

Subjetividade e Sentimento; o Sentimento como expressão da Subjetividade. Schiller (1759-1805), refletindo sobre esse assunto em 1795, no alvorecer do Romantismo, afirmou "o que dá alimento ao caráter sentimental: amor exaltado, sentimentalismo pela Natureza, sentimentos religiosos, espírito de contemplação filosófica e, por fim, para nada esquecer, o mundo ossiânico sombrio, informe e

\footnotetext{
${ }^{73}$ Mario Praz. Op cit, p 34

${ }^{74}$ Hegel. Curso de Estética: O Sistema das Artes, p. 404

${ }^{75}$ Howard Phillips Lovecraft. O Horror Sobrenatural na Literatura, pp 11-12
} 
melancólico." ${ }^{76}$ Acrescentaríamos que a troca do adjetivo sentimental pelo adjetivo romântico (realizada, aliás, por August Wilhem Schlegel cerca de dez anos mais tarde) nos daria uma nítida definição do que era a nova escola. Porém, cabe reconhecer que essas características gerais apontadas por Schiller não eram novidade na produção artística ocidental, elas aparecem em vários autores da Renascença e do Barroco, tais como Shakespeare, Cervantes, Garcilaso e Marino, para citar alguns. Numa tentativa de equacionar melhor essa questão, Friedrich Schlegel argumentou "o romântico não é tanto um gênero quanto um elemento da Poesia, que nela predomina em maior ou menor grau, mas nunca deve faltar completamente." 77 Seria razoável supor que essas discussões entre os teóricos do movimento romântico, que ganhou força na Alemanha nos últimos anos do século XVIII e expandiu-se para o resto da Europa nos lustros do Império Napoleônico, tenham fornecido argumentos (alguns deles bastante sólidos) àqueles que, como 0 já citado Paulo Prado, veem Romantismo e Classicismo como elementos que se alternam na cultura do Ocidente desde a Antiguidade.

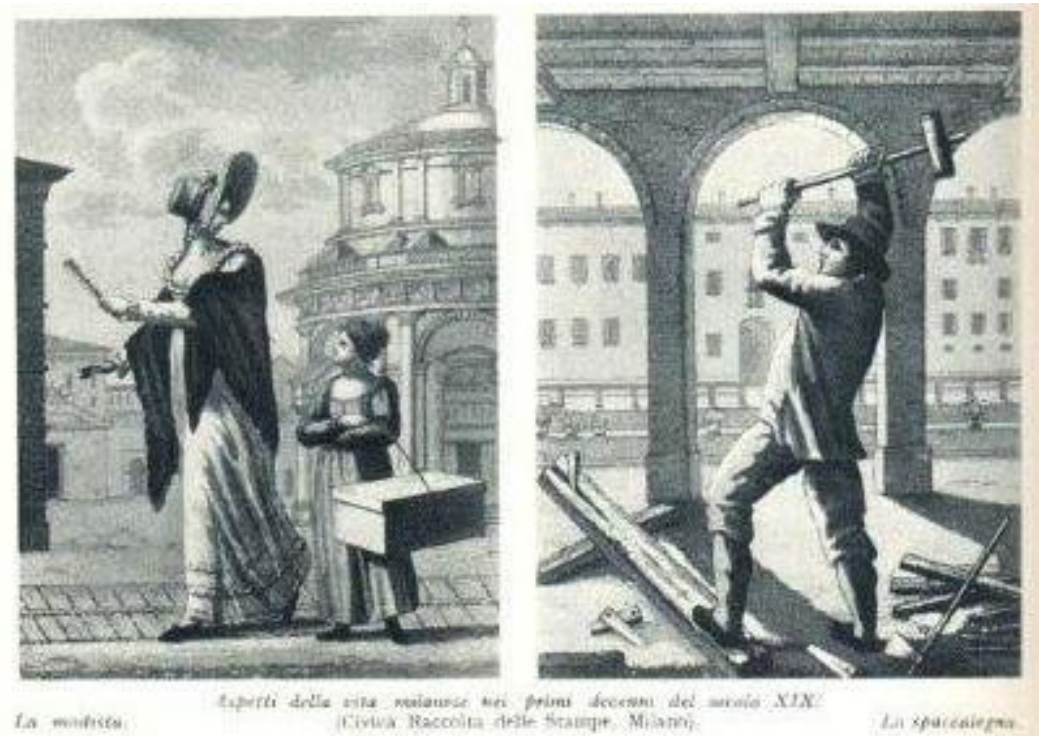

Cenas da vida milanesa nas primeiras décadas do século XIX: a modista, o cortador de lenha (in Cesare Spellanzon. Storia del Risorgimento e dell'unità d'Italia, p.620)

Outro aspecto a ser considerado quando investigamos as definições para o adjetivo Romântico são as distorções interpretativas que esse termo sofreu com o passar dos tempos. Werner Kohlschimidt nos alerta "o Romantismo é algo bem

\footnotetext{
${ }^{76}$ Schiller. Poesia Ingênua e Sentimental, p. 78

${ }^{77}$ Friedrich Schlegel. Conversa sobre a Poesia e outros fragmentos, p. 67
} 
diverso daquela atmosfera das florestas, dos rios e dos fantasmas que, devido a fatores externos secundários, foi mais tarde erroneamente considerado o aspecto essencial do movimento." Acrescentaríamos que, para piorar o quadro, a noção romântica do Amor foi apropriada, durante o século XX, pela indústria do entretenimento, o que levou a uma banalização do Romantismo, esvaziado de seu caráter originalmente revolucionário. Nos estudos acadêmicos, como lembra Kohlschimidt, "devido à falta de clareza do vocábulo e pela confusão causada na ciência literária, criou-se um ceticismo quanto à utilidade do conceito como fórmula científica literária exata." 78 É como se pudéssemos entender que estudiosos e críticos em busca de conceitos e interpretações precisos no campo da Estética não deveriam se aventurar em searas românticas. Para Giovanni Macchia, "não devemos nos impressionar se as definições sobre o Romantismo que continuam a acender-se e apagar-se, como vagalumes, na crítica literária ao longo dos tempos, sejam tão controversas e contraditórias." É possível inferir que a proposta original dos românticos era serem controversos e contraditórios, uma vez que eles não desejavam seguir regras e preceitos como fizeram os adeptos do Classicismo. Dessa forma, no entendimento de Macchia, o Romantismo "é uma corrente que acompanha a Europa por decênios, na sua metamorfose literária, política, econômica, filosófica e social; está em franco acordo ou em duelo aberto com os princípios e a História, e não pode ser considerada senão em sua duração e em sua extensão; na sua força de penetração em diferentes regiões e em diferentes épocas." 79

Friedrich Schlegel, por muitos considerado o maior teórico do Romantismo, define "romântico é justamente o que nos apresenta um conteúdo sentimental em uma forma de fantasia." Ele pede para que esqueçamos o sentido trivial daquilo que geralmente consideramos ligado aos sentimentos e pergunta: "o que é então esse sentimental? O que nos agrada, onde o sentimento domina, mas aquele sentimental espiritual, não o que provem dos sentidos." É possível inferir que Schlegel se refere a uma sensação estética superior, a um refinamento dos sentidos que leve o Homem para uma dimensão além da Materialidade. Ele mesmo explica "a fonte e alma de todas essas emoções é o Amor, e na poesia romântica é preciso que esteja

\footnotetext{
${ }^{78}$ Werner Kohlschmidt. "O Romantismo" in Bruno Boesch (org). História da Literatura Alemã, pp 326-327

${ }^{79}$ Giovanni Macchia. "Origini europee del Romanticismo" in Emilio Cecchi e Natalino Sapegno (org).

Storia della Letteratura Italiana, volume settimo, L’Ottocento, p. 369 (nossa tradução)
} 
pairando, quase invisível e por toda a parte, o espírito do Amor; é isto que aquela definição deve apontar." 80 Seria razoável supor que essa ênfase no Amor, considerado como meio de comunhão com o Absoluto, foi em grande parte responsável pela popularidade da escola romântica. Isso se explica pela legitimação do Sentimento como uma afirmação da Individualidade, algo caro às gerações nascidas após a Revolução Francesa que tornaram-se fautoras das revoluções liberais da década de 1820 e dos governos constitucionais das décadas de 1830 e 1840, na Europa e alhures.

Poderíamos continuar nossa busca por uma definição do termo romantismo por muitos outros críticos e comentadores, através da "formidável bibliografia que dele se ocupa”, como disse Paulo Prado, mas nossa hipótese de interpretação é que como conceito estético o Romantismo nasceu na Inglaterra na década de 1750, usado para definir pinturas e gravuras de lugares algo melancólicos, com uma coloração predominantemente acinzentada. O sentimento provocado por essas representações pictóricas passou a ser evocado em algumas obras literárias. A partir de então tornou-se romântico o ato de sensibilizar-se (emocionar-se) com a visão ou descrição de lugares ermos, ruínas medievas e florestas sombrias. Já o período histórico que corresponde ao Romantismo é muito amplo, porque identificamos esse conceito com as profundas transformações ocorridas no Ocidente entre 1750 e 1830, aproximadamente. Estamos nos referindo à Revolução Industrial, à Revolução Americana, à Revolução Francesa, às guerras napoleônicas, ao processo de independência das colônias europeias no Novo Mundo, às revoluções liberais e a muitos outros acontecimentos menores, mas não menos significativos da história ocidental. O Romantismo é a ideologia dessa época, conturbada e revolucionária em todos os sentidos.

\subsection{0 confronto}

O Romantismo é geralmente definido como sendo o oposto do Classicismo, e foram os próprios românticos que assim se posicionaram. No afã de contestar a estrutura cultural de sua época os fautores da nova escola, influenciados pelo caráter revolucionário que insuflava as multidões nas décadas finais do século XVIII,

\footnotetext{
${ }^{80}$ Friedrich Schlegel. Op cit, p. 165
} 
a tudo quiseram se opor. Romance, Poesia, Drama, Comédia, Pintura, Escultura, Filosofia, História, Ciências da Natureza, precisavam de um novo olhar, de uma nova abordagem. Desejava-se uma ruptura definitiva com o Passado, ou melhor dizendo, com os paradigmas estéticos que vinham pautando a criação artística desde a Renascença. Havia espaço para a contestação dos padrões estabelecidos e um anseio de experimentação de outros modos de expressão, principalmente no campo das Artes. ${ }^{81}$

Aquilo que denominamos Classicismo, ou seja, a produção artística e intelectual dos séculos XVI, XVII e de grande parte do século XVIII, não pode ser visto como um bloco monolítico. Partindo da Renascença, passando pelo Maneirismo, adentrando as várias fases do Barroco, atravessando o Rococó e terminando no Neoclassicismo temos um conjunto vastíssimo de obras que representam períodos históricos muito diferentes e específicos, tais como a renascença italiana, o maneirismo flamengo, o barroco espanhol, para citar apenas alguns exemplos. Existe algo em comum entre os tragediógrafos franceses, os marinistas italianos e os autores do século de ouro da Espanha que nos permita classificá-los em uma categoria única? Sim, todos eles são clássicos. Eles usam preferencialmente a Poesia e não a Prosa como meio de expressão; empregam, em diferentes graus, as lendas da mitologia greco-romana como fonte de inspiração; e adotam uma distinção nítida de gêneros. Foram essas características gerais que deram ao Classicismo uma unidade estilística e permitiram ajustes pontuais que explicam a sua longa duração. ${ }^{82}$

O Classicismo foi um conjunto de concepções estéticas que orientou a criação artística europeia do início do século XVI até as décadas finais do século XVIII. Segundo Franklin Leopoldo e Silva, "quando os pensadores do Renascimento inventaram o classicismo da Antiguidade, operaram um determinado juízo de valor que via na cultura antiga a realização de certos ideais de harmonia e beleza." 83 É como se pudéssemos entender que a visão que procurava renovar a cultura medieval (renovação tornada possível pela redescoberta de várias obras de cunho

\footnotetext{
${ }^{81}$ Paulo Vizzioli. "O Sentimento e a Razão nas poéticas e na poesia do Romantismo" in J. Guinsburg (org). O Romantismo, pp 137-156. Ver também: Eric J. Hobsbawn. A Era das Revoluções, pp 275299; Harold Osborne. Estética e Teoria da Arte, pp 178-192

${ }^{82}$ Para uma introdução ao estudo dos temas abordados neste parágrafo recomendamos J. Guinsburg (org). O Classicismo; em especial os ensaios de Giselle Beiguelman. "Classicismo, o Mundo como Abstração", pp 63-86. Aguinaldo José Gonçalves. "O Classicismo na Literatura Europeia”, pp 115-138 ${ }^{83}$ Franklin Leopoldo e Silva. "O Classicismo em Filosofia" in J. Guinsburg (org). O Classicismo, p. 88
} 
filosófico trazidas para a Itália após a queda de Constantinopla e o fim do Império Romano do Oriente) baseou-se na apropriação de ideias geradas em diferentes períodos da Antiguidade: da Grécia ao fim do Império Romano, de Platão e Aristóteles a Quintiliano e Aulo Gélio, por exemplo. De acordo com Giselle Beiguelman, "o período compreendido entre o século XVI e meados do século XVIII não se singulariza por supostas rupturas, mas sim por uma série de continuidades." ${ }^{84}$ Seria razoável supor que tenham existido um ou vários elementos estabilizadores que proporcionaram essa "série de continuidades". Para João Alexandre Barbosa, "durante aqueles três séculos, quer a matéria de discussão teórica, quer a efetivação poética, orbitaram em torno de algumas categorias, regras e modelos que embasaram todas as criações artísticas e reflexões filosóficas que lhes davam sustentação ou eram delas decorrentes." ${ }^{85}$ Acrescentaríamos que o Classicismo, na verdade, enquanto construção teórica, apoiou-se em três princípios: Ordem, Unidade e Universalidade.

Examinando essas questões teóricas diz Franklin Leopoldo e Silva, "decorre da sabedoria de Deus a racionalidade do Universo e, portanto, a correspondência entre a ordem do pensamento e a ordem da realidade." ${ }^{86}$ É possível inferir que o elemento ordenador, aquele que estabiliza o sistema é Deus, ou seja, o Classicismo funda suas raízes na concepção da ordem divina. Por isso, de acordo com o autor, "a absoluta unidade ontológica faz de todas as coisas e de cada uma a expressão de Deus." 87 Tudo o que existe na Natureza provém de Deus, o supremo criador do Universo. A harmonia que há entre os seres, assim como a relação desses mesmos seres com o Cosmos é fruto da ordem divina. Prevalece, portanto, apenas um princípio criador, que unifica todas as coisas. No entender de Giselle Beiguelman, com isso "a cultura clássica é uma cultura monocular por excelência. (...) A noção de harmonia que prevalece é aquela dotada de um centro geométrico, que unifica e dá equilíbrio à ordem racional da Natureza." 88 Isso nos leva ao segundo princípio fundamental do Classicismo: a Unidade.

O elemento unificador do pensamento classicista é a Razão. De acordo com Giselle Beiguelman, "sendo a cultura da identidade e da diferença, da ordem e da

\footnotetext{
${ }^{84}$ Giselle Beiguelman. "Classicismo, o Mundo como Abstração" in J. Guinsburg (org). Op cit p. 64

${ }^{85}$ João Alexandre Barbosa. "Introdução" in J. Guinsburg (org), Op cit, p. 13

${ }^{86}$ Franklin Leopoldo e Silva. Op cit, p. 93

${ }^{87}$ Idem, p. 96

${ }^{88}$ Giselle Beiguelman. Op cit, p. 80
} 
média, o Classicismo se funda sob o princípio da intolerância e da razão una." 89 Seria então razoável supor que aquilo que não pudesse ser ordenado de forma racional dentro de uma unidade coerente estaria fora dos limites determinados por uma cultura de matriz classicizante, daí resultando o caráter intolerante ressaltado pela autora. A ideia central desse conceito, segundo Franklin Leopoldo e Silva, seria que "a extensão do poder da Razão deve proporcionar ao Homem, através da perfeita integração entre Teoria e Prática, o estado de felicidade." ${ }^{90}$ No Classicismo, nos alerta João Alexandre Barbosa, "é íntima a relação entre a obra de poesia ou de arte e a reflexão sobre ela." ${ }^{91}$ De tudo isso podemos inferir que o ponto de partida da criação artística classicista é a Reflexão, já que ela ordena racionalmente os elementos de que o artista dispõe para executar sua obra. E que elementos seriam esses? Aqueles legados e consagrados pela Tradição, que fornecem à obra de arte a sua legitimidade, conferida pelo juízo que a Crítica faz sobre ela. $E$ assim chegamos ao terceiro princípio fundamental da escola classicista: a Universalidade.

O juízo crítico é fruto do uso da Razão, resultado de uma reflexão acurada sobre a obra de arte. Quando falamos em Classicismo nos remetemos a um conceito de produção artística que considera a construção do Belo como o ideal supremo da Arte. Ao adotar o critério formulado por gregos e romanos, qual seja, a Beleza é o produto da harmonia das formas, os classicistas procuraram estabelecer regras que definissem de maneira clara e objetiva essa relação. A tarefa era, porém, um tanto quanto complexa: inferir conceitos que haviam orientado a criação de obras com mais de mil anos de idade.

Para resolver esse problema era preciso descobrir preceitos que fossem válidos em qualquer época ou em qualquer contexto histórico. No entender de Franklin Leopoldo e Silva, para os classicistas "é o alcance do princípio racional que garante a universalidade das produções da Razão. Princípio universal permite universalidade do Conhecimento." 92 É como se pudéssemos entender que o estudo dos tratados sobre a Arte herdados da Antiguidade produzissem regras que orientassem a produção coeva, colocando-a no caminho aberto pelos grandes mestres do Passado. É isso o que vemos nas poéticas dos italianos Júlio César

\footnotetext{
${ }^{89}$ Idem, p. 81

${ }^{90}$ Franklin Leopoldo e Silva. Op cit, p. 104

${ }^{91}$ João Alexandre Barbosa. Op cit, p. 14

${ }^{92}$ Franklin Leopoldo e Silva. Op cit, p. 98
} 
Escalígero (c. 1484-1558) e Ludovico Castelvetro (1505-1571), escritas no século XVI, e do francês Nicolas Boileau-Despréaux (1636-1711), redigida no século XVII. Leopoldo e Silva nos explica, "a universalidade do Belo só pode provir das regras da Razão e, portanto, a forma na Arte deve naturalmente ser concebida a partir da aplicação de tais regras." ${ }^{93}$ Nossa hipótese de interpretação é que o Classicismo elegeu o conceito de beleza como objetivo primordial da Arte. Dentro da concepção classicista o Belo só pode ser alcançado pela ordenação racional dos elementos constitutivos da Obra (seja ela uma pintura, uma poesia, uma escultura, uma narrativa em prosa, uma catedral ou um palácio), que deve espelhar a harmonia da Natureza, que é a obra de Deus, o criador supremo. E da mesma forma como as belezas naturais são universais e atemporais, essas também devem ser as características do belo classicista. É contra essas concepções que se insurgiu o Romantismo.

Para muitos estudiosos Classicismo e Romantismo não são escolas estéticas com regras e padrões definidos, são elementos recorrentes que aparecem ao longo da história intelectual do Ocidente. Dessa forma, toda vez que a produção artística se apoia em fontes reconhecidas pela Tradição a cultura é clássica, e quando o pêndulo da criação balança para o lado do Local e do Característico a cultura é romântica. Por exemplo, o teatro ateniense do século V A.C. seria clássico, uma vez que se apropriava das narrativas de Homero e de Hesíodo; já a comédia nova do período helenístico seria romântica porque tirava seus argumentos da realidade coeva. Nossa hipótese interpretativa não endossa essa visão. Neste estudo os termos clássico e romântico estão circunscritos a movimentos culturais específicos em épocas históricas determinadas e que se contrapõem devido a transformações sociais, políticas e econômicas palpáveis e identificáveis em um contexto histórico explícito. É esse recorte metodológico que nos permitirá analisar, em termos teóricos, os limites e as contradições da passagem do Classicismo ao Romantismo na cultura europeia e em suas diversas apropriações.

\footnotetext{
${ }^{93}$ Idem, p. 112
} 
Em 1823, no calor do debate entre românticos e classicistas na França, Stendhal (1783-1842), um dos mais ardorosos propagandistas do movimento romântico, declarou:

\footnotetext{
O Romantismo é a arte de apresentar aos povos as obras literárias que, no estado atual de seus costumes e crenças, possuem a capacidade de lhes proporcionar o maior prazer possível.

O Classicismo, ao contrário, apresenta-lhes a literatura que proporcionava o maior prazer possível aos seus bisavós. ${ }^{94}$
}

Podemos notar nessa passagem um dos principais argumentos usados pelos românticos: a cultura de matriz clássica era anacrônica. Não estava em discussão se as obras dos classicistas eram belas, se eram bem trabalhadas ou se educavam através do deleite (muito embora, na maioria dos casos, essas qualidades fossem negadas pelos críticos da nova escola) mas simplesmente que a forma de expressão que essas obras usavam (o verso, a língua latina, a rigidez da composição em gêneros estanques) não oferecia mais fruição estética, ou seja, não cumpria o papel da verdadeira Arte.

Escrevendo no início da década de 1820, Stendhal reclamava: "segundo historiadores, jamais povo algum sofreu, em seus costumes e nos seus divertimentos, uma mudança mais súbita e total do que o de 1780 a 1823; e ainda querem nos apresentar a mesma literatura!" 95 Podemos inferir desse trecho de Racine e Shakespeare a constatação das alterações provocadas pela Revolução Francesa e pela Revolução Industrial na vida dos franceses nos anos da Restauração e o reconhecimento da visão anacrônica do Classicismo. Em oposição à ordem e à universalidade classicistas os românticos, segundo Anatol Rosenfeld $\mathrm{e}$ J. Guinsburg, irão exaltar "a esfera do Uno, que almeja atingir a grande síntese em todos os planos, mas principalmente na criação artística." À guisa de esclarecimento diremos que a unidade romântica é muito diferente da unidade criada pelos classicistas: nesta o que se busca é uma obra fechada, cujos elementos se aglutinam por força de um princípio que orienta e harmoniza a disposição das diferentes partes, previamente selecionadas por um juízo de valor baseado em uma estrita concepção de beleza, que se acreditava ser uma herança da Antiguidade. $O$ ideal romântico, na definição de nossos autores, "é a obra de arte total, integradora de todas as obras, que reúna todos os gêneros e todos os ramos da Cultura,

\footnotetext{
${ }^{94}$ Stendhal. "Racine e Shakespeare" in Samuel Johnson. Prefácio a Shakespeare, seguido de Racine e Shakespeare por Stendhal; cap. III, p. 105

${ }^{95}$ Idem, p. 108
} 
fundindo-os e exprimindo-os na Arte." 96 É como se pudéssemos entender a obra romântica na forma de uma composição aleatória que vai se estruturando por uma lógica própria, onde cabem todos os elementos que o artista deseja nela colocar. Se os classicistas advogam, por exemplo, a tragédia em versos alexandrinos e a comédia em versos soltos, os românticos propõe a tragicomédia, onde verso e prosa se misturam sem qualquer restrição formal. No Classicismo uma pintura ou uma escultura devem se estruturar em fórmulas matemáticas de composição e proporção, os românticos sonham quadros tridimensionais e esculturas pictóricas, sinfonias de cores e arquiteturas de sons. Para Rosenfeld e Guinsburg, "em toda a parte, o Romantismo ressalta e valoriza essas transposições e integrações das artes." 97 Acrescentaríamos que muitas das propostas formais dos teóricos românticos não foram desenvolvidas pelo Romantismo, porém tanto o Simbolismo como o Expressionismo apropriaram-se do irracionalismo romântico para criar uma arte muito mais radical em termos de forma e de conteúdo que fundamentou a cultura do século XX.

Contudo, como lembra Harold Osborne, "se bem formem um dos principais contrastes nas classificações críticas, tanto o Clássico quanto o Romântico são modos de arte 'ideal'. Ambos encerram conceitos de nobreza, grandeza e superioridade e envolvem uma reorganização do ambiente cotidiano com a repulsa do Usual e do Vulgar." 98 Qual seria então a diferença? O ideal clássico se apresenta, no geral, como a possibilidade de uma unidade dentro da qual o Homem e a Sociedade podem ser aprimorados através da experiência estética. Dentro desse conceito a obra de arte possui um valor pedagógico, uma vez que ela permite vivenciar emoções não usuais de forma controlada, nos limites impostos pela Razão, soberana implacável do gênero humano. O artista romântico enfrenta uma ruptura entre o seu íntimo (o que ele deseja expressar) e o mundo que o cerca, sempre hostil aos seus sentimentos mais profundos. Seria razoável supor que, na concepção romântica, quanto mais original for o artista, menores serão os meios que ele terá à sua disposição para realizar a sua obra. É por isso que os românticos exaltarão a folha em branco contendo o poema jamais escrito, a sinfonia sentida no

\footnotetext{
${ }^{96}$ Anatol Rosenfeld e J. Guinsburg. "Um encerramento" in J. Guinsburg (org). O Romantismo, p. 289

${ }^{97}$ Idem, p. 290

${ }^{98}$ Harold Osborne. Estética e Teoria da Arte, pp 178-179
} 
fundo da alma e jamais executada por qualquer instrumento ou a tela vazia, que nenhum pincel ou tinta jamais poderá preencher. De acordo com Stendhal,

\footnotetext{
É preciso coragem para ser romântico, pois implica risco.

O clássico prudente, ao contrário, jamais dá um passo adiante sem se apoiar, em segredo, em algum verso de Homero ou em uma observação filosófica de Cícero, em seu tratado Da Velhice. ${ }^{99}$
}

O artista romântico viu o mundo ao seu redor sofrer transformações rápidas e abruptas, e por isso sua atitude perante os acontecimentos que vivia não podia ser a mesma das gerações anteriores. Para Hegel (1770-1831), "do ponto de vista do ideal clássico, no sentido rigoroso da palavra, toda a ação e todo o evento se efetuam visando a um fim, verdadeiro e necessário em si, cujo conteúdo determina tanto a forma exterior como a maneira que os concretiza no real." Seria possível inferir da afirmação do filósofo alemão que o artista clássico está para sua obra como um artesão diante de seu material de trabalho. A ele cabe escolher quais elementos, entre os fornecidos pelo paradigma da cultura clássica de inspiração greco-romana, entrarão na composição de seu trabalho e como estruturá-los de forma a criar algo original cujo fim seja aprimorar o gosto estético de seus apreciadores, que julgarão o seu talento pela habilidade com que ele reelabora as fontes de que dispõe. Na arte clássica deve aparecer a obra e não o artista. Ainda segundo, Hegel, "não é o caso das ações e eventos tratados pela arte romântica. Embora os fins cuja realização representa sejam de natureza geral e substancial, não são eles que dirigem a ação, que regulam a ordem e a sucessão das suas fases, mas deixam-na evoluir livremente em todos os aspectos, ao sabor dos acasos e acidentes da realidade exterior." ${ }^{100}$ Em vista do aqui exposto por Hegel seria razoável supor que o artista romântico não está diante do material de sua obra, mas do ambiente ao seu redor ele coleta aquilo que melhor possa servir aos seus propósitos expressivos. Não existe um paradigma pré-determinado e o artista deve ser o criador dos meios através dos quais ele se expressa. O gênio romântico (a verdadeira força criadora) não ordena racionalmente os elementos da Natureza, ele gera a sua própria natureza, faz suas próprias regras e amplia a percepção daqueles que entram em contato com o seu trabalho. Para os críticos românticos Talento é sinônimo de Originalidade, e o valor da obra está ligado àquilo que ela traz de inovador. Na arte romântica deve aparecer o artista e não a obra. No Romantismo

\footnotetext{
${ }^{99}$ Stendhal. Op cit, p. 106

${ }^{100}$ Hegel. Curso de Estética: O Belo na Arte, p. 641
} 
não existe a preocupação do artista em ajustar a sua criatividade aos meios disponíveis para expressá-la. O romântico dá livre curso às suas ideias, ele não se prende a fórmulas pré-estabelecidas e vai criando por si as maneiras de expressar aquilo que ele sente em seu íntimo. É por isso que o movimento romântico teve de inventar novas categorias de análise crítica, ao mesmo tempo em que confrontava os ditames da razão clássica. ${ }^{101}$

Com a evolução do debate entre classicistas e românticos vão surgindo novas interpretações e novos argumentos que ampliam a questão. Em 1834, Heinrich Heine (1797-1856), instado por amigos a escrever um livro em resposta a obra de Madame de Staël De I'Alemagne, publicou Contribuição à História da Religião e Filosofia na Alemanha. Nesse estudo Heine argumentava "as expressões clássico e romântico se referem (...) apenas ao tratamento", ou seja, na maneira de confecção da obra. No entender do autor quando Forma e Ideia são idênticas o artista trabalhou classicamente, como fizeram os gregos, cuja arte procura harmonizar o que se expressa com o meio pelo qual se expressa, dando identidade à obra por coesão dos elementos internos a ela. O artista trabalha romanticamente, segundo Heine, "se a forma não revela a ideia mediante identidade, mas deixa adivinhar essa ideia." Não existe a preocupação de adequar forma e conteúdo e por isso "quase sempre vemos deformidade." 102 É como se pudéssemos conjecturar que o mundo do artista romântico está fora de controle; a realidade exposta nas obra românticas não é regulada por uma harmonia racional, mas regida por categorias que escapam ao domínio do razoável. Acrescentaríamos ainda que frequentemente a arte romântica exalta o Grotesco, o Demoníaco, a Irracionalidade e o Acaso. Em resumo, diríamos que à sobriedade da arte clássica opõe-se a agitação da arte romântica.

Examinemos, de maneira sucinta, como os românticos introduziram elementos operativos que, muito embora não fossem propriamente novos ou necessariamente originais, contribuíram para formular uma teoria estética contrária aos preceitos classicistas. Em 1798, Friedrich Schlegel escreveu Conversa sobre a Poesia, um diálogo nos moldes daqueles compostos por Platão, onde vários

\footnotetext{
${ }^{101}$ Para uma análise mais ampliada dos assuntos tratados neste parágrafo consultar Anatol Rosenfeld e J. Guinsburg. "Romantismo e Classicismo" in J. Guinsburg (org). O Romantismo. A conceituação classicista e a conceituação romântica de Inspiração e de Originalidade são examinadas em Harold Osborne. Op cit, pp 185-192

${ }^{102}$ Heinrich Heine. Contribuição à História da Religião e Filosofia na Alemanha; livro primeiro, pp $49-50$
} 
personagens expõem diferentes pontos de vista sobre a produção cultural da época, não apenas na Alemanha, mas também na Inglaterra e na França. Essa obra (originalmente publicada em capítulos na revista Athenaeum, editada por Friedrich e seu irmão August Wilhelm Schlegel) é considerada a principal reflexão teórica dos primeiros anos românticos produzida em língua alemã. O cerne da argumentação está contido na "Carta sobre o Romance", escrita por um dos personagens e lida pelos demais. Nessa missiva diz Schlegel: "a Loucura é a coisa mais linda que pode

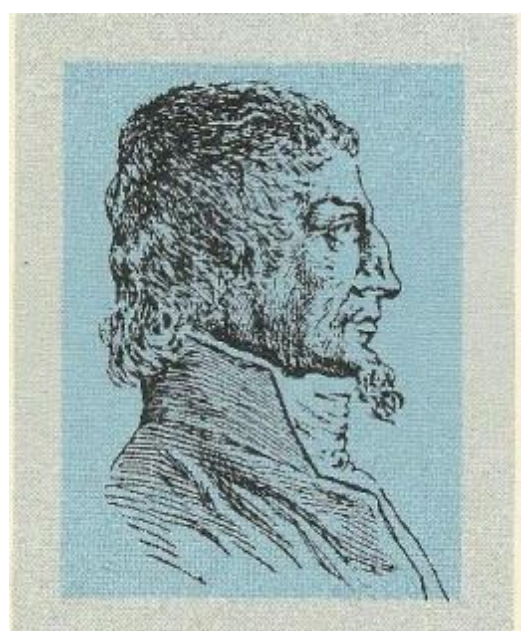
o Homem imaginar, o verdadeiro princípio supremo de tudo o que é divertido." 103 Podemos inferir dessas palavras um ataque direto à Razão, estrutura básica do Classicismo, contrapondo como elemento ordenador do discurso a Loucura, que não deleita nem instrui, mas diverte. O autor confessa "quase não posso conceber um romance que não seja uma mistura de narrativa, canção e outras formas." ${ }^{104}$ É razoável supor que existe nessa passagem uma objeção "quase" radical à Unidade, tão cara aos fautores do Classicismo. $\mathrm{Na}$ opinião de Schlegel, "uma teoria do romance teria de ser, ela mesma, um romance que reproduzisse fantasticamente cada nota eterna da Fantasia e que de novo gerasse o caos do mundo dos cavaleiros andantes." ${ }^{105}$ É como se pudéssemos entender que, para o autor, o importante não é a construção do Belo, como um espelho fiel das perfeições da Natureza, mas a criação do Caos, produto do uso indiscriminado da Fantasia, geradora de formas não naturais, nunca antes imaginadas.

Em nossa hipótese de interpretação Friedrich Schlegel identifica três polos de oposição ao Classicismo: Loucura contra Razão; Fantasia contra Ordem; Particular contra Universal. No primeiro polo os românticos exaltam estados de inconsciência (possessão demoníaca, hipnotismo, sonambulismo) que levam a comportamentos e atitudes incompatíveis com o uso da Razão, dessa maneira abrindo um leque de situações e cenas não contempladas pelas poéticas do Classicismo. Não que isso fosse uma novidade absoluta: desde $\mathrm{O}$ Elogio da Loucura, de Erasmo de Roterdã

\footnotetext{
${ }^{103}$ Friedrich Schlegel. Conversa sobre a Poesia e outros fragmentos, p. 64

104 Idem, p. 68

105 Idem, ibidem.
} 
(1466? - 1536), às pinturas de Breughel e às criações do Rococó o elemento racional fora questionado em maior ou menor grau, mas não repudiado de forma tão contundente como podemos observar nos contos de E. T. A. Hoffmann (1776-1822) e de Edgar Allan Poe (1809-1849) e nas gravuras de Francisco de Goya (17461828), por exemplo. A loucura romântica introduz na Arte o elemento noturno (não por acaso a principal obra de Hoffmann intitula-se Contos Noturnos), a glorificação das trevas e o terror a uma natureza obscura, desconhecida e incontrolável. O segundo polo coloca em evidência um elemento já usado nas produções do Barroco e do Rococó: o Grotesco. Não pretendemos fazer aqui uma análise teórico-crítica do Grotesco, apenas mostrar como ele foi apropriado de forma radical pelos românticos. A ordem classicista parte da ideia que todo o conhecimento provém de Deus, criador e ordenador das coisas do Universo; já os românticos acreditam que o Mundo está desorganizado e sob influência do Diabo. O elemento grotesco introduz, assim, na produção romântica o Sobrenatural e o Inverossímil. Podemos citar como exemplo as gravuras de Goya (as séries Os Horrores da Guerra e Caprichos) e as pinturas de Johann Heinrich Füssli (1741-1825). Esse é o mundo das feiticeiras, dos duendes, das fadas, dos espectros e dos espíritos malignos onde o Demônio impõe a sua (des)ordem. Segundo Wolfgang Kayser, "o Grotesco destrói fundamentalmente as ordenações e tira o chão sob os pés." ${ }^{106}$ Seria razoável supor que estamos diante não da habilidade do Artista em retratar placidamente a Natureza, mas da capacidade do Artista de construir imagens só por ele imaginadas. Isso nos leva ao terceiro polo por nós identificado na Conversa sobre a Poesia, de Friedrich Schlegel: Particular contra Universal. O uso do Latim, da Mitologia e da Alegoria garantia, no entender dos fautores do Classicismo, a universalidade da produção artística: desde que o receptor tivesse acesso ao código (mitologia grecoromana, por exemplo), a obra seria imediatamente reconhecida, não importando o local e a época em que fora realizada. Isso não vale para a estética romântica: se todo o artista pode e deve gerar uma natureza e uma ordem que expressem a sua fantasia particular, a obra romântica não tem a pretensão da Universalidade nem da Atemporalidade, muito pelo contrário, ela pretende ser a expressão de uma personalidade única colocada em um lugar e em uma época precisos. Podemos citar como exemplos dessa exaltação ao Particular Os Sofrimentos do Jovem

\footnotetext{
${ }^{106}$ Wolfgang Kayser. O Grotesco, p. 61
} 
Werther, de Goethe (1749-1832) e As Últimas Cartas de Jacopo Ortis, de Ugo Foscolo (1778-1827). Vale recordar que nesses dois romances epistolares o desenrolar da trama e o seu desfecho expõem o conflito entre o mundo interior dos protagonistas (Werther e Ortis) e a sociedade na qual eles estão inseridos, ou seja, existe uma particularização tanto dos caracteres envolvidos no enredo como do momento histórico no qual este se desenvolve.

Personalidade emblemática dos conturbados Anos Românticos, Nicolò Ugo Foscolo nasceu no dia 6 de fevereiro de 1778 em Zante, uma das llhas Jônicas, hoje território grego porém naquela época uma possessão da antiga República Vêneta. Seu pai, Andrea Foscolo, era médico e membro de uma antiga família veneziana; sua mãe, Diamantina Spathis, era grega. Ugo viveu em Zante a maior parte de sua infância, e após o falecimento de seu pai, quando ele tinha dez anos, foi deixado pela mãe junto com os irmãos na casa de uma tia. Aos quatorze anos, em 1792, ele mudou-se para Veneza, indo viver com sua mãe, sem ter ainda aprendido a língua italiana. Começava ali a sua aventurosa vida. Cinco anos mais tarde, em janeiro de 1797, foi representada com sucesso no Teatro Sant'Angelo, sua tragédia Trieste. No final daquele ano, no dia 9 de novembro, Foscolo fugiu de Veneza por razões políticas e refugiou-se em Milão, então capital da filo-francesa República Cisalpina. Em abril de 1799 ele alista-se na Guarda Nacional de Bolonha, luta ao lado das tropas francesas de Napoleão Bonaparte, é ferido duas vezes e deixa o exército com a patente de capitão após a Batalha de Marengo. Em 1804 ele encontrava-se em Paris, onde traduziu a Viagem Sentimental de Yorick, de Lawrence Sterne (17131768). Após algumas aventuras amorosas Foscolo retornou a Milão em 1806 . Foi durante algum tempo professor de literatura na Universidade de Pavia. Sua aula inaugural no ano de 1809 foi a palestra Dell'origine e dell'ufficio della Letteratura. Em virtude das posições políticas assumidas durante o governo de Eugênio Beauharnais, que Foscolo apoiou no princípio e que criticou posteriormente, ele não inspirava muita confiança aos governantes austríacos do Reino Lombardo-Vêneto criado após a Restauração, em 1814. Apesar disso, depois dos tumultos ocorridos em Milão em março de 1815, sufocados pelas tropas do Marechal Bellegarde, Foscolo foi por este último procurado com a proposta de dirigir um jornal favorável à administração austríaca (Biblioteca italiana). A princípio ele aceitou o encargo porém, pouco antes de prestar juramento ao Imperador Foscolo mudou de ideia e partiu para o exílio, jamais retornando à Itália. Após sofrer perseguições por parte 
dos austríacos na Suíça, ele chegou a Londres em 12 de setembro de 1816. Sua estadia na Inglaterra foi marcada por muitas dificuldades econômicas e também de relacionamento, tanto com outros exilados italianos como com a intelectualidade britânica, que o recebeu de braços abertos, mas acabou por fechar-Ihe as portas em razão dos desregramentos de Foscolo. Por fim ele terminou seus dias na miséria, falecendo a 10 de setembro de 1827 em Turnham Green, nas proximidades de Londres. Depois da reunificação da Itália seus restos mortais foram transferidos para a Igreja da Santa Cruz, em Florença, em 1871. ${ }^{107}$

Sabemos que Ugo Foscolo começou a escrever As Últimas Cartas de Jacopo Ortis em setembro de 1798, vinte e quatro anos após Goethe publicar Os Sofrimentos do Jovem Werther (1774). De acordo com Maria Antonietta Terzoli, "obra em contínuo progresso, Ortis acompanha Foscolo desde a primeira juventude

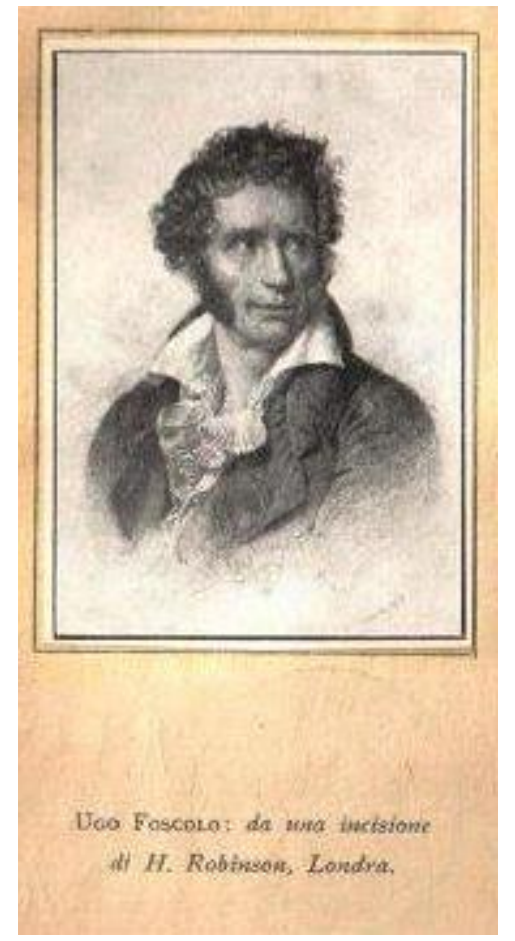
até a plena maturidade modificando-se com o tempo e adaptando-se, seja em nível narrativo seja em nível estilístico, às diferentes condições de vida de seu autor." 108 De oficial (ferido em combate) das forças napoleônicas a exilado perseguido pelo governo austríaco, o autor foi alterando sua obra, através de acréscimos e supressões, a cada edição: a primeira em 1799; a segunda em 1802; a terceira em 1816; até a quarta, e definitiva, em 1817. Como o nome indica o romance é a narrativa, em forma epistolar, do último período de vida (outubro de 1797 a março de 1799) do suicida Jacopo Ortis. Italiano combatente no exército napoleônico o personagem é obrigado a se exilar em um pequeno vilarejo após o Tratado de Campoformio (1797). Ali ele se apaixona perdidamente por uma beldade local, já prometida em casamento a um nobre da terra. Após uma troca de beijos Ortis se convence de

107 Sobre Ugo Foscolo consultar Lanfranco Caretti. "Ugo Foscolo" in Emilio Cecchi e Natalino Sapegno. Storia della Letteratura Italiana, volume VII, L'Ottocento, de onde tiramos a maioria das informações para a confecção deste parágrafo. Ver também Boletim, n. .20 (nova série) do Departamento de Letras Modernas da Faculdade de Filosofia, Letras e Ciências Humanas da Universidade de São Paulo intitulado "Homenagem a Ugo Foscolo; Omaggio" (1979)

${ }^{108}$ Maria Antonietta Terzoli. "Ugo Foscolo" in Enrico Malato (org). Storia della Letteratura Italiana, volume VII, II Primo Ottocento, p. 400 (nossa tradução). Ver também Irineo Sanese. "Foscolo" in Enciclopedia Italiana di Scienze, Lettere ed Arte, volume XV (1931) 
duas coisas: ser correspondido em seus sentimentos e a impossibilidade da quebra dos laços matrimoniais da amada. Decide então partir e inicia uma viagem pela Itália, lançando um olhar desesperançado pelo país e descrevendo o cenário histórico e político da Península no início do século XIX. Informado das núpcias de seu grande amor, Ortis retorna ao ponto de partida e ali se mata, não como Werther, com um tiro na têmpora, porém mais romanticamente, apunhalando o próprio coração. As influências de Foscolo são claras: Goethe (Werther), Rousseau (A Nova Heloísa) e Laurence Sterne (Viagem Sentimental de Yorick). Pela criação intensa de uma sensibilidade atormentada pelas estruturas sociais do momento histórico no qual estava inserido, As Últimas Cartas de Jacopo Ortis é ainda hoje considerado um dos mais importantes romances escritos em língua italiana no século XIX.

Acreditamos que tudo o que foi aqui colocado pode ser sintetizado por um aforismo publicado na revista Athenaeum em 1798, atribuído a Friedrich Schleiermacher (1768-1834):

Do ponto de vista romântico, mesmo os gêneros bastardos, excêntricos e monstruosos têm seu valor, enquanto matéria-prima e exercícios preliminares da Universalidade, se - ao menos - neles houver alguma coisa, se ao menos forem originais. ${ }^{109}$

Muito já se falou sobre os malefícios e os benefícios da Revolução Industrial. É inegável que Humanidade sofreu uma grande transformação graças às invenções e às novas tecnologias desenvolvidas durante esse período histórico. Uma época, aliás, de difícil demarcação: teria começado por volta de 1760 e se estendido, para alguns, até 1900; para outros, até 1914, ou então terminado por volta de 1930, de acordo com algumas versões. Desde os pioneiros Richard Arkwright (1732-1792) e James Watt (1736-1819), que inovaram o ramo têxtil com máquinas capazes de multiplicar a quantidade de tecidos produzida por um único trabalhador, aos fabricantes de aço Henry Bessemer (1813-1898) e Alfred Krupp (1812-1887), cujos produtos foram a matéria-prima para novos armamentos e também possibilitaram a construção de toda uma infraestrutura mais sólida e mais barata, chegando a

\footnotetext{
${ }^{109}$ A edição brasileira da obra de Friedrich Schlegel Conversa sobre a Poesia e outros fragmentos traz vários aforismos publicados na revista Athenaeum, inclusive este, na página 101.
} 
inventores/empresários como Werner Siemens (1816-1892), criador do dínamo, e Rudolph Diesel (1858-1913), o inventor do motor a ar comprimido, grande impulsionador da indústria automobilística. Na verdade, o trabalho desses grandes gênios da Engenharia, da Mecânica e da Construção moldou a economia do século XIX e foi determinante para a melhoria das condições de vida de toda a Humanidade, que usufruiu seus benefícios ao longo do século XX. ${ }^{110}$

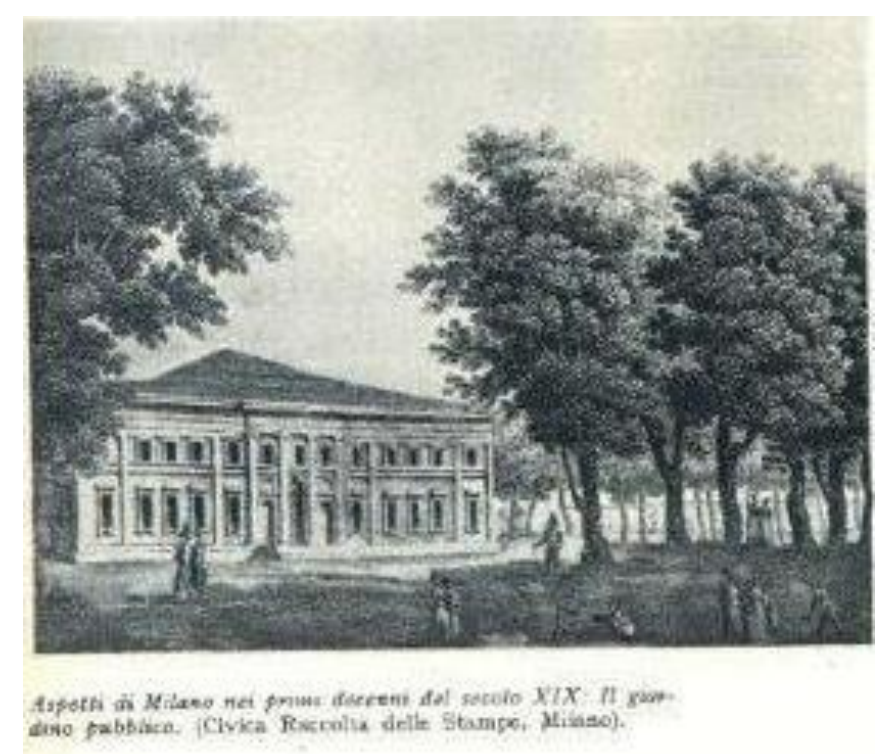

Vista de Milão nas primeiras décadas do século XIX: o jardim público (in Cesare Spellanzon. Storia del Risorgimento e dell'unità d'Italia, p.621)

Porém, mesmo para seus contemporâneos, a principal marca da Revolução Industrial não foi o seu legado desenvolvimentista, mas as condições sociais que ela criou: a concentração da riqueza, a degradação do trabalho, a destruição de rios e de florestas e as precárias moradias nas metrópoles que o avanço da indústria originou. Segundo Eric J. Hobsbawn, "o novo estabelecimento industrial médio - a fábrica, a forja ou a mina - era pequeno e cercado por uma grande quantidade de mão de obra barata, doméstica, subcontratada e tecnicamente retrógrada" ${ }^{111} \mathrm{Na}$ opinião de W. O. Henderson, "a Revolução Industrial teve consequências dramáticas para todos os grupos de trabalhadores. Os operários nas fábricas, os mineiros nas minas de carvão, os artífices nas suas oficinas, e os camponeses na terra, tinham que se ajustar a um modo de vida inteiramente novo." 112 Henderson lembra ainda que "após a Revolução Industrial, um operário tinha às vezes de percorrer uma

\footnotetext{
${ }^{110}$ Ver a esse respeito W. O. Henderson. A Revolução Industrial, especialmente os capítulos 1 e 2

${ }^{111}$ Eric J. Hobsbawn. A Era das Revoluções, p. 193

${ }^{112}$ W. O. Henderson. Op cit, p. 122
} 
considerável distância a pé para chegar à fábrica, enquanto sob o anterior sistema doméstico ele trabalhava em casa." 113 De acordo com Hobsbawn, "as cidades e as áreas industriais cresciam rapidamente, sem planejamento ou supervisão, e os serviços mais elementares da vida da cidade fracassavam na tentativa de manter o mesmo passo: a limpeza das ruas, o fornecimento de água, os serviços sanitários, para não mencionarmos as condições habitacionais da classe trabalhadora." 114 Para Henderson, "as condições nos centros de trabalhadores nas cidades industriais não eram melhores do que as condições nas fábricas. (...) A falta de água potável e de privadas, os esgotos impróprios e a ausência de cisternas, tornavam as cidades industriais lugares extremamente insalubres." 115 Em consequência essas grandes aglomerações urbanas eram frequentemente assoladas por epidemias de cólera e de tifo que dizimavam populações, como a ocorrida em 1830, por exemplo.

De acordo com Henderson, para piorar ainda mais a condição de vida dos trabalhadores, "quase todas as indústrias tinham as suas doenças características e as suas deformidades físicas. Os oleiros, os pintores e os cortadores de arame sofriam de envenenamento pelo chumbo; os mineiros, de tuberculose, de anemia, de vista, e de deformações da espinha; os afiadores, de asma; os fiandeiros, de perturbações brônquicas; os fabricantes de fósforo, de envenenamento pelo fósforo." ${ }^{116}$ Além disso, segundo o estudioso, "no fim das guerras napoleônicas" - período no qual nosso estudo está centrado - "os inquéritos relativos à mão-de-obra de 41 fábricas escocesas e 48 de Manchester mostraram que metade dos operários eram crianças". 117 Não é nosso propósito fazer uma avaliação dos custos políticos e sociais do progresso tecnológico gerado pela Revolução Industrial, queremos apenas chamar a atenção para o fato de que a produção artística e cultural dessa época (que denominamos pelo nome genérico de Romantismo) não poderia estar alheia às contradições criadas pelo modelo econômico do tempo. No entanto, é necessário observar que a Revolução Industrial não ocorreu simultaneamente em todos os países ocidentais e por isso seus benefícios e seus malefícios foram sentidos em contextos históricos diferentes ao longo do século XIX e dos princípios do século $X X$.

\footnotetext{
${ }^{113}$ Idem, p. 128

${ }^{114}$ Eric J. Hobsbawn. Op cit, p. 224

${ }^{115}$ W. O. Henderson. Op cit, p. 129

${ }^{116}$ Idem, p. 123

${ }^{117}$ Idem, p. 127
} 
No final do século XVIII, em meio ao impacto provocado pelas transformações sócio-econômicas produzidas pela Revolução Industrial, Schiller (1759-1805) indagava: "Por que o indivíduo grego era capaz de representar seu tempo e não pode ousá-lo o indivíduo moderno?" Nessa questão podemos detectar o busílis do debate entre românticos e classicistas: a falência da visão clássica e o seu anacronismo. Na opinião do poeta alemão "porque aquele recebia suas forças da Natureza, que tudo une, enquanto este as recebe do Entendimento, que tudo separa." Schiller acredita que o problema esteja na cultura coeva, que tolheu a natureza humana da possibilidade de realizar-se em sua plenitude, já que o mundo moderno tornou-se, a seu ver, "uma engenhosa engrenagem cuja vida mecânica, em sua totalidade, é formada pela composição de infinitas partículas sem vida." Em

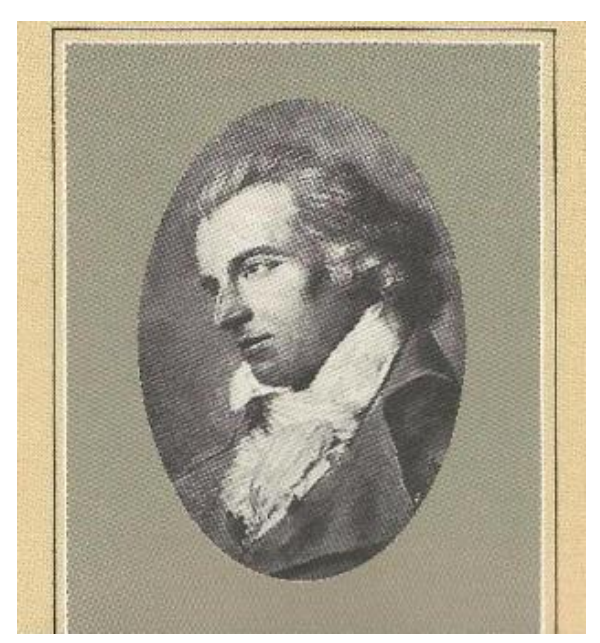
uma sociedade constituída dessa forma, segundo Schiller, "divorciaram-se o Estado e a Igreja, as leis e os costumes; a fruição foi separada do trabalho; o meio, do fim; o esforço da recompensa." Seria razoável supor, diante de tal afirmação, que não é mais possível para a Arte representar o Mundo como uma unidade estável, ordenada pela Razão, ao abrigo das contradições da vida comum. Schiller entende que "eternamente acorrentado a um pequeno fragmento do todo, o Homem só pode formar-se enquanto fragmento." Por isso a Arte perde sua capacidade de harmonizar a natureza humana, uma vez que não existe mais uma totalidade formadora da identidade do Homem. No mundo moderno, de acordo com Schiller, "a letra morta substitui o entendimento vivo, a memória bem treinada é guia mais segura que Gênio e Sensibilidade." ${ }^{118} \mathrm{Em}$ nossa hipótese de interpretação as palavras do grande romântico alemão são uma antevisão dos males que a sociedade de massas, produto da industrialização, causaria à cultura ocidental. O Conhecimento passa a ser uma simples ferramenta de produção, e o Indivíduo não é mais do que uma peça do grande motor da economia de escala. A Arte torna-se um bem de consumo cuja função é entreter, distrair, nos poucos momentos de ócio permitidos pelo trabalho mecânico na imensa engrenagem industrial.

\footnotetext{
${ }^{118}$ Schiller. A Educação Estética do Homem numa série de cartas, carta VI, pp 40-41
} 
Essa questão do distanciamento da obra de arte, assim como a percepção de que ela não faz parte da vida cotidiana do indivíduo moderno, já que foi substituída por simulacros adaptáveis à progressiva alienação das massas nas sociedades industriais, foram objeto de reflexão por parte de um grupo de intelectuais alemães, de orientação marcadamente marxista, conhecido como Escola de Frankfurt. Walter Benjamin (1892-1940) constatou que a Arte, nas sociedades contemporâneas, perdeu o valor de culto que ela possuía nos tempos pré-capitalistas. Assim, segundo ele, "na medida em que diminui a significação social de uma arte, assistese, no público, um divórcio crescente entre o espírito crítico e o sentimento de fruição." 119 Para o autor os indivíduos modernos perderam o poder de concentração que permitia aos seus antepassados um contato íntimo e pessoal com a obra de arte. Os modernos desejam, no seu entender, que a Arte tenha um poder de distração.

De acordo com Theodor Adorno (1903-1969) o público moderno deseja ser encantado e não retratado pela Arte. Porém, segundo ele, "os momentos de encantamento demonstram-se irreconciliáveis com a constituição imanente da obra de arte, e esta sucumbe àqueles toda a vez que a obra artística tenta elevar-se para a transcendência." É razoável supor que esse desejo constante do público torna os artistas contemporâneos meros ilusionistas, produtores de truques maravilhosos capazes de surpreender e de encantar as massas. Para Adorno, os artistas "colocam-se a serviço do sucesso, renunciam ao impulso insubordinado e rebelde que Ihes era próprio, conjuram-se para aprovar e sancionar tudo o que um momento isolado é capaz de oferecer a um indivíduo isolado (...)." ${ }^{120} \mathrm{O}$ indivíduo imaginado por Schiller: íntegro, dono de sua personalidade e senhor absoluto de seu gosto artístico, "há muito tempo já deixou completamente de existir", nas palavras de Theodor Adorno. ${ }^{121}$ Ele acredita que "o fascínio da canção da moda, do que é melodioso, e todas as variantes da Banalidade, exerce a sua influência desde o período inicial da Burguesia." 122

O que podemos inferir das colocações de Walter Benjamin e de Theodor Adorno, que expuseram suas reflexões em um tempo que o avanço cronológico hoje

\footnotetext{
${ }^{119}$ Walter Benjamin. "A obra de arte na época de suas técnicas de reprodução" in Os Pensadores, volume XLVIII, p. 27

${ }^{120}$ Theodor Adorno. "O fetichismo na Música e a regressão da Audição" in Op cit, p. 176

${ }^{121}$ Idem, ibidem

122 Idem, p. 177
} 
coloca entre nossa época e os Anos Românticos, é que o Romantismo (primeiro movimento artístico-cultural engendrado após a Revolução Industrial) levantou questões e mostrou problemas e contradições que ainda estão próximos de nossa contemporaneidade, o que justifica, mesmo nos dias de hoje, duzentos anos após o surgimento da escola romântica, uma (re) leitura atenta de seus conceitos.

Em 1827, Victor Hugo (1802-1885) escreveu um ensaio chamado Do Grotesco e do Sublime. Inicialmente um prefácio a sua peça Cromwell, essa pequena obra foi depois considerada o manifesto do movimento romântico francês. No entender do jovem Hugo, "a musa épica dos Antigos havia somente estudado a Natureza sob uma única face, repelindo sem piedade da Arte quase tudo o que, no mundo submetido à sua imitação não se referia a um certo tipo de belo." É justamente esse "tipo de belo" que está agora em discussão, uma vez que, segundo o grande romântico, "a musa moderna verá as coisas com um olhar mais elevado e mais amplo." Podemos inferir que os progressos econômicos e as transformações sociais gerados a partir da segunda metade do século XVIII modificaram a visão de mundo da geração nascida após a década de 1780, tornando-a muito diferente de seus pais e avós. O mundo surgido depois da Revolução Francesa, do Império Napoleônico, da Restauração de 1815 e das revoluções liberais da década de 1820 não pôde mais ser reconhecido como uma unidade, produto de uma razão unificadora. Para Hugo, os modernos devem sentir "que o Feio existe ao lado do Belo, o Disforme perto do Gracioso, o Grotesco no reverso do Sublime, o Mal com o Bem, a Sombra com a Luz." ${ }^{123}$ É como se pudéssemos entender que existe um paradigma muito mais vasto na arte romântica do que aquele usado pelos classicistas. O belo clássico é absoluto, uma depuração da Forma através de procedimentos herdados de uma era supostamente perfeita, a Antiguidade. $O$ belo romântico é relativo, ele nasce de um confronto entre opostos e está colocado em relação a uma forma que lhe é contrária. Essa foi a maneira pela qual os românticos tentaram expressar as contradições do momento histórico no qual estavam inseridos.

${ }^{123}$ Victor Hugo. Do Grotesco e do Sublime, pp 24-25 

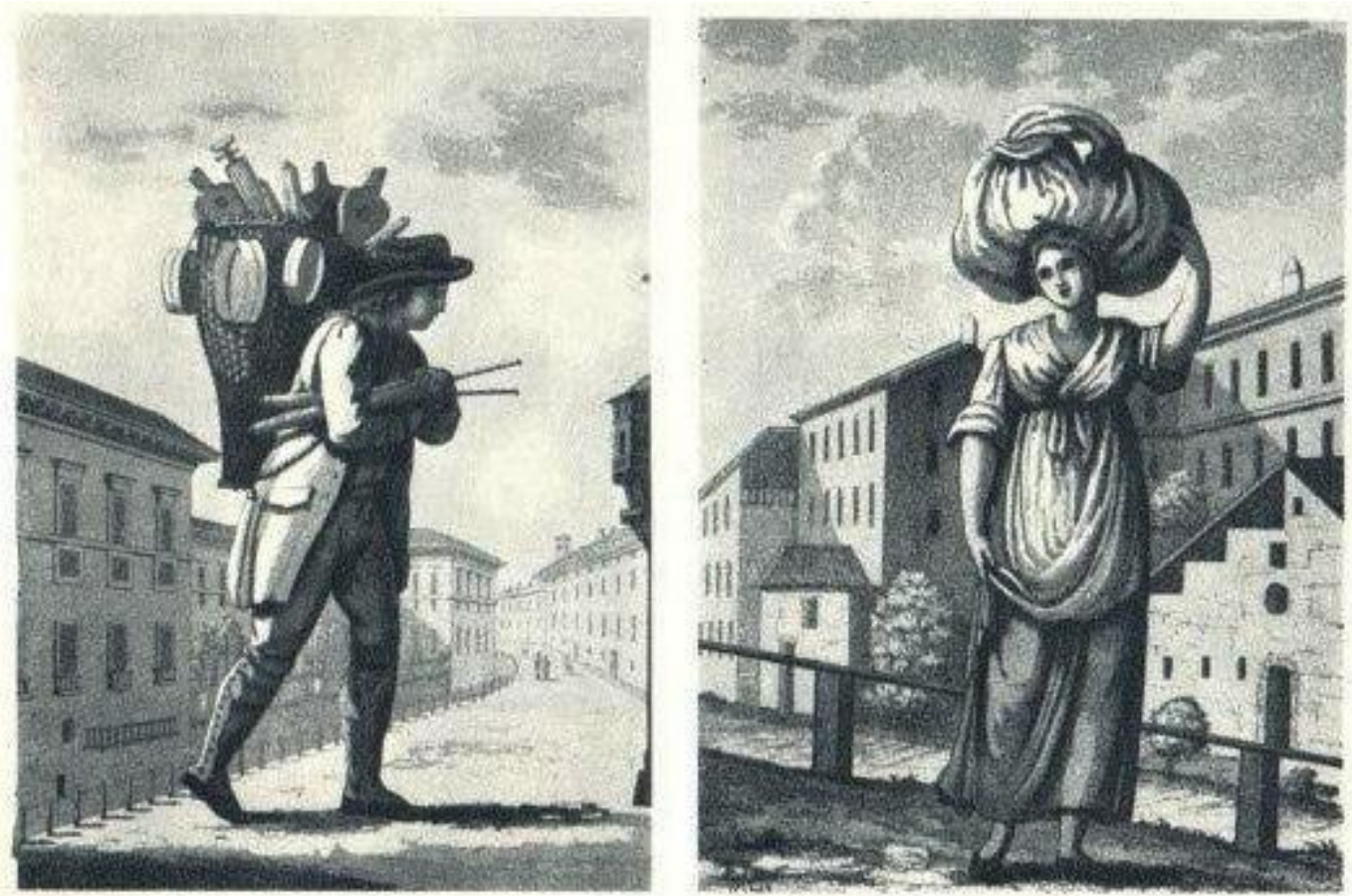

II setacciaio.

Aspelti della vita malanese nei primi decenent ded secolo $X / X$ :

(Crvica Raccolta delle Stampe, Mitano).

Cenas da vida milanesa nas primeiras décadas do século XIX: o carregador, a lavadeira (in Cesare Spellanzon. Storia del Risorgimento e dell'unità d'Italia, p.617)

Nesse debate sobre as formas de expressão, Hegel acredita "o ideal clássico é aquele que apresenta o Absoluto como tal na sua independente realidade, que repousa sobre si própria, enquanto a arte romântica exprime a subjetividade do Espírito e do Sentimento na sua infinitude, ao mesmo tempo que na sua particularidade finita." ${ }^{124} \mathrm{O}$ Classicismo busca representar a Atemporalidade, aquilo que não pode ser destruído pela passagem dos séculos. O Romantismo pretende expressar o Mundo como ele é apreendido pelo sentimento do Artista. É como se pudéssemos entender que a arte clássica vale-se de alegorias, de sentimentos e de emoções gerais, compartilhados por todo o gênero humano. A arte romântica busca inspiração naquilo que é local, específico de uma determinada sensibilidade. artista clássico julga-se herdeiro de uma tradição milenar, que remonta aos gregos e aos romanos, e para assegurar a transmissão fiel dessa cultura às novas gerações existem as academias com suas regras descritas em inúmeras poéticas.

Academia era o nome de um descampado a noroeste de Atenas onde foram erguidos quatro templos: a Zeus, às Musas, a Mercúrio e a Hércules. 
Posteriormente foram ali plantadas inúmeras árvores que deram origem a um frondoso bosque. Foi nesse local, muito frequentado pelos atenienses, que Platão, retornando a Atenas em 378 A.C., passou a reunir seus alunos e discípulos. Quando alguns anos depois o filósofo erigiu o prédio de sua escola nas proximidades do bosque, essa passou a ser conhecida pelo nome daquele: Academia. A academia platônica funcionou por mais de novecentos anos, sendo fechada em definitivo no ano 529 da Era Cristã por ordem do imperador Justiniano sob a alegação de que ela era um centro difusor de ideias pagãs combatidas pelo Cristianismo, a religião oficial do Império. ${ }^{125}$

As academias modernas, que reúnem grupos de pessoas interessadas em discutir, promover e divulgar a literatura e a ciência, surgiram na Itália no século XV e se espalharam pelo resto da Europa no século XVII. Sabe-se que a primeira academia moderna, com seus estatutos e corpos diretivos, foi a Chorus Academiae Florentinae, fundada em Florença na metade dos Quatrocentos. ${ }^{126}$ Se por um lado as academias de letras e de ciências aparecem como centros de discussão e de inovação, as academias de belas-artes têm seu foco principal no ensino das técnicas de pintura, desenho e escultura. Fenômeno típico italiano, depois transportado para o resto do Mundo, a mais antiga academia de belas-artes foi a Reale Accademia delle Arti e del Disegno, inaugurada em Florença na primeira metade do século XIV. As academias mais importantes promoviam salões e distribuíam prêmios, muito disputados pelos artistas que desejavam ingressar no mundo das artes. ${ }^{127}$ As academias musicais também procuravam desenvolver artes correlatas como o Canto e a Dança. A mais antiga academia musical europeia foi a Accademia degli Accesi, constituída em Bolonha na segunda metade dos Quinhentos. Do século XVI ao século XVIII houve uma grande expansão das academias musicais na Itália, onde praticamente toda cidade possuía uma, e os principais centros urbanos e culturais contavam com duas ou mais. A partir do século XIX surgem as academias nacionais, geralmente apoiadas e patrocinadas

\footnotetext{
${ }^{125}$ Goffredo Coppola. "Accademia" in Enciclopedia Italiana di Scienze, Lettere ed Arti, volume I (ed. 1929)

${ }^{126}$ Giuseppe Gabrieli. Op cit.

${ }^{127}$ Nello Tarchiani. Op cit.
} 
pelos Estados, com o intuito de agregar os talentos nativos e de promover a produção cultural e científica das nações. ${ }^{128}$

Diferentemente dessa tradição acadêmica, o artista romântico preocupa-se em expressar as suas emoções, dar vida àquilo que só ele pode sentir. 0 Romantismo está muito vinculado à sua época, à história recente e às novas expressividades proporcionadas pelo progresso da Civilização. Para o romântico não existem modelos herdados e muito menos tradição e a ser seguida. Ele confia apenas em sua sensibilidade e no seu talento, e por isso a sua obra deve ser original, sem comparação com o que existia antes dele. Acrescentaríamos ainda que os românticos abriram uma caixa de Pandora. Do inconsciente do Artista saem as mais disparatadas criações; não existe um limite físico, ou plausível, para a estética romântica. Tudo é válido à criatividade dos fautores da nova escola: o Feio, o Bizarro, o Mau, o Caricato estão ao lado do Belo, do Gracioso, do Bom, do Nobre. É como se todos os adjetivos, todos os caracteres, achassem abrigo sob a extensa marquise do Romantismo.

Seriam clássico e romântico dois conceitos recorrentes na estética do Ocidente? Apareceriam eles ao longo da história da cultura ocidental como categorias de análise crítica? Algumas correntes de pensamento acreditam ser possível tal generalização. Poderíamos ilustras os argumentos do debate através da divergência emblemática entre Friedrich Schiller e Friedrich Schlegel, teóricos românticos que se ocuparam do tema no início do século XIX. Schiller, oferecendo uma visão generalizadora, divide os poetas em dois grupos: os ingênuos (clássicos) e os sentimentais (românticos). Para ele, "todos os que são realmente poetas pertencerão ou aos ingênuos ou aos sentimentais, conforme seja constituída a época em que florescem ou conforme as condições acidentais sobre a formação geral ou sobre a disposição momentânea de suas mentes." ${ }^{129}$ Dessa forma, Schiller afirma que clássico e romântico são na verdade categorias críticas, que apresentam características gerais identificáveis em diferentes épocas. Em oposição está

\footnotetext{
${ }^{128}$ Adelmo Damerini. Op cit. O verbete "Accademia" na edição de 1929 da Enciclopedia Italiana é extenso e foi escrito por vários especialistas de diferentes áreas.

${ }^{129}$ Schiller. Poesia Ingênua e Sentimental, p. 57
} 
Schlegel, para quem na poesia clássica, "não é absolutamente tomada em consideração a diferença entre Verdade e Aparência, entre Seriedade e Jogo. Nisto reside a grande diferença. A poesia antiga segue a Mitologia à risca e até evita 0 conteúdo propriamente histórico. (...) A poesia romântica, por outro lado, repousa completamente sobre bases históricas, muito mais do que se sabe ou se acredita." É possível inferir dessa discussão que não se trata da "formação geral" ou da "disposição momentânea da mente" do poeta, conforme afirmava Schiller. O artista clássico está limitado por um modelo de perfeição, que ele busca como um ideal supremo; o artista romântico, que procura na experiência histórica a inspiração para suas obras, é capaz de expressar os sentimentos, as fraquezas e as contradições de sua época. Ainda segundo Schlegel, "Boccaccio parte quase sempre de histórias verdadeiras, assim como as outras fontes das quais é derivada toda a invenção romântica." 130

Nossa hipótese de interpretação é que os românticos rebelaram-se contra uma tradição alegórica que vinha da Renascença. A valorização da antiguidade greco-romana ganhara contornos de evidente exagero retórico nas obras do Barroco. Mesmo as tentativas de realizar uma arte mais despojada feitas pelos artistas rococós e neoclássicos não foram bem sucedidas uma vez que as mudanças sócio-econômicas (i. e. a ascensão da Burguesia) não favoreciam esse tipo de representação artística. A Arte deixou progressivamente de ser um elemento de glorificação de uma camada social dominante, tal como acontecia no Antigo Regime, para tornar-se um foco de insatisfação com a acumulação capitalista e o utilitarismo da vida burguesa. A nova dinâmica das relações sociais imposta pela Revolução Industrial não permitiu mais a estabilidade ideológica na qual o Classicismo se assentara por trezentos anos. ${ }^{131}$

\footnotetext{
${ }^{130}$ Friedrich Schlegel. Op cit, p. 66

${ }^{131}$ Sobre esse assunto ver Peter Gay. A Experiência Burguesa da Rainha Vitória a Freud, volume I, A Educação dos Sentidos, pp 42-57
} 


\section{CAPÍTULO 3 UM JORNAL ROMÂNTICO: IL CONCILIATORE}

\subsection{A renovação}

No dia 9 de agosto de 1818 Silvio Pellico enviou, de Milão, uma carta a Ugo Foscolo, já então exilado em Londres, na qual anunciava "Rasori, Breme e outros, na maior parte caríssimos amigos seus (entre os quais me incluo) faremos um jornal que sairá dia 3 de setembro próximo." ${ }^{132} \mathrm{E}$ de fato, na quinta-feira 3 de setembro de 1818 ganhava as ruas milanesas II Conciliatore, com o subtítulo de Foglio Scientifico-Letterario, portando o dístico latino... Rerum concordia discors. O jornal vinha impresso em quatro folhas azuis na tipografia de Vincenzo Ferrario, localizada na Rua de San Vittore e 40 Martiri, n. .980 . Devido a cor do papel no qual vinha impresso logo ganhou o apelido de Foglio Azzuro (folha azul). Um mês depois da carta acima mencionada, isto é, em 9 de setembro de 1818, Pellico escrevia a Foscolo: "Te falei, parece, na minha última [carta] que se imprime em Milão um novo jornal literário - uma iniciativa sem fins comerciais, porém obra de espíritos sinceros, amantes da difusão do verdadeiro." Entre os "amantes da difusão do verdadeiro" Pellico cita, além de si mesmo, Giovanni Rasori, Ludovido di Breme, Pietro Borsieri, Giovanni Berchet e Jean-Charles - Leonard Sismonde de Sismondi. ${ }^{133}$ Apesar de sua curta existência (118 números publicados duas vezes por semana, às quintas-feiras e aos domingos, durante 13 meses: de 3 de setembro de 1818 a 17 de outubro de 1819) I/ Conciliatore foi o veículo introdutor, na Itália, das ideias românticas que dominavam os debates culturais, estéticos e filosóficos na Inglaterra e na Alemanha desde os lustros finais do século XVIII.

Na década de 1830 apareceu a primeira edição completa de /l Conciliatore: os cento e dezoito números do jornal foram encadernados em um único volume de 478 páginas, tendo como introdução o programa escrito por Pietro Borsieri. As demais edições fac-similares do periódico seguiram a numeração de páginas dessa primeira. Com relação aos comentadores do jornal existem três livros fundamentais: Il Conciliatore e i Carbonari, de Cesare Cantù (Milano: Fratelli Treves Editori,

\footnotetext{
${ }^{132}$ Silvio Pellico. Epistolario, p. 17 (nossa tradução). "Rasori, Breme ed altri, la più parte amici tuoi caldissimi (e vi sono io), faremo un giornale, uscirà il 3 settembre prossimo."

${ }^{133}$ Idem, pp 18-19. "Ti dissi, mi pare, nell'altra mia che si stampa un nuovo giornale letterario a Milano. - Impresa non mercantile, ma d'animi sinceri amanti la diffusione del vero. - I soci sono Rasori, Breme, Borsieri, Berchet, io ed altri, fra i quali Sismondi di Ginevra. Ti mando i due primi numeri del nostro giornale."
} 
1878); II Conciliatore - periodico milanese (1818-1819), de Edmondo Clerici (Pisa: Nistri, 1903); e II Conciliatore, de Andrea Gustarelli (Milano: Fratelli Treves Edtori, 1918). O mais importante deles é o de Cantù ${ }^{134}$, referência obrigatória em qualquer estudo sobre o tema.

Cesare Cantù nasceu em Brivio, na província de Como, no dia 5 de dezembro de 1804 e morreu em Milão no dia 11 de março de 1895. Devotou sua vida à História e à crítica literária, divulgando em seus escritos uma quantidade enorme de fatos importantes e curiosos. Iniciou seus estudos no Ginásio de Sant'Alessandro, em Milão, visando a carreira clerical, que abandonou posteriormente, mantendo, no entanto, muito de sua formação religiosa na construção de sua obra intelectual. Cantù foi de início professor, aos dezoito anos, no ginásio da vila de Sondrio, e depois de quatro anos passou a lecionar no ginásio da cidade de Como. A residência nessa localidade inspirou-lhe duas obras: o poema romântico Algiso (1828) e o ensaio Storia della città e della diocese di Como (1829-1831). Retornou a Milão em 1832 para ensinar na escola onde fora aluno, o Ginásio de Sant'Alessandro. Foi a partir de então que passou a frequentar o círculo íntimo do escritor Alessandro Manzoni, resultando dessa intimidade a obra La Lombardia nel secolo XVII (1832), e ulteriormente os livros Abate Parini e la Lombardia nel secolo passato (1854) e Reminiscenze su Alessandro Manzoni (1882). Em todos esses trabalhos é manifesta uma marcante característica de Cantù, também presente em II Conciliatore e i Carbonari (1878): uma visão profundamente pessoal dos fatos históricos, não raro considerada imprecisa pelos críticos, aliada a uma tendência de opor, de uma maneira frequentemente maliciosa, os vivos aos mortos e os mortos aos vivos.

Outras obras históricas relevantes que saíram da pena de Cantù foram Notizia di G. D.Romagnosi (1835) ${ }^{135}$; Beccaria e il Diritto Penale (1862); Alcuni Italiani contemporanei (coletânea de artigos, 1868); Italiani illustri (coletânea de

\footnotetext{
${ }^{134}$ Gostaríamos de agradecer imensamente ao Prof. Dr. Luís Antonio Lindo, que gentilmente nos enviou por correio eletrônico a cópia digitalizada de II Conciliatore e i Carbonari disponível na biblioteca digital da Universidade de Stanford.

${ }_{135}$ Gian Domenico Romagnosi (Salsomaggiore, 11 de dezembro de 1761 - Milão, 8 de junho de 1835) foi ativo colaborador de II Conciliatore.
} 
biografias, 1873-1874); Monti e l'età che fu sua (1879). Cesare Cantù tornou-se uma celebridade com a publicação do romance histórico Margherita Pusterla, em 1838. Foi nesse mesmo ano que saiu o primeiro dos trinta e cinco volumes da sua História Universal, finalizada em 1846. Embora considerada por muitos superficial e pouco precisa, a coleção de fatos, acontecimentos e opiniões sobre diversas épocas históricas coletada por Cantù agradou em cheio ao público italiano de meados do século XIX, e foi traduzida também em outras línguas europeias. O sucesso dessa obra muito deveu ao estilo franco e direto de Cantù, que não economiza comentários ácidos e mordazes acerca dos personagens e dos fatos que aborda. Nessa mesma linha ele escreveu Storia di cento anni (1851), Storia degli Italiani (1854-1856), Gli eretici d'Italia (1865-1866), Della indipendenza italiana

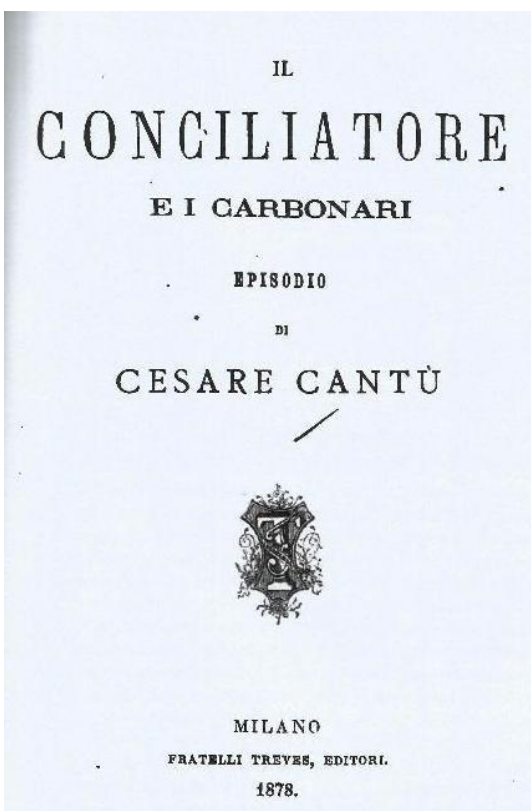
(1872-1877) e Gli ultimi trent'anni (1879). Na verdade, Cesare Cantù divide opiniões: muitos o consideram um escritor brilhante, autor de algumas das mais belas páginas escritas em língua italiana no século XIX; para outros ele é um pensador pouco profundo e um historiador impreciso. ${ }^{136}$

O livro II Conciliatore e i Carbonari tem como subtítulo "Episódio de Cesare Cantù", que de certa forma explica o propósito da obra. Episódio pode ser definido como um fato notável, ligado a outros acontecimentos (um episódio da História do Brasil, por exemplo). No "Proemio", Cantù nos diz que dentre os "milhares de jornais que nasceram e morreram" a Lombardia ainda se lembra de dois, que muito embora tenham tido uma curtíssima existência, deixaram uma impressão duradoura: II Caffè e II Conciliatore. O autor alega ter já falado do primeiro em um livro anterior (Beccaria e il Diritto Penale, Firenze: 1862) e que deseja agora dedicar-se ao segundo "não tanto pelo jornal em si, mas pelas pessoas que o obraram." Para isso ele aproveitou "o acaso ter-nos posto em mãos muitas cartas" de autoria dos intelectuais que fizeram parte do grupo de II Conciliatore (i conciliatori) o que the deu ensejo de apresentar "sob um novo aspecto um tempo e

\footnotetext{
${ }^{136}$ Guido Mazzoni. "Cantù, Cesare" in Enciclopedia Italiana di Scienze, Lettere ed Arti, volume VIII, p. 809.
} 
um momento histórico que poderiam ter gerado excelentes venturas, mas que, ao contrário, produziram mártires." Cantù alega que a epistolografia é um "gênero muito desprezado entre nós", mas que permite, no entanto, "surpreender seus autores em trajes domésticos (veste da camera), (...) com juízos que saltam da pena sem a preocupação que outros os recolham." 137

O livro II Conciliatore e i Carbonari foi lançado em Milão no ano de 1878, ou seja, exatos sessenta anos após o lançamento de I/ Conciliatore, numa Itália unida e independente. Na opinião de Cesare Cantù, "é, no entanto, deplorável querer imolar todo o Passado à glorificação do Presente, supor que a Itália começou somente em 1858 com Cavour e La Farina, repetir que a Itália dormia, era morta e por fim caluniar aquelas tentativas [de unificação realizadas décadas antes] como infantilidades de artistas, que arriscavam a pele e chegavam a lugar nenhum." Seria razoável supor que o autor se insurge contra a triunfalismo de uma linhagem de políticos e de intelectuais que conseguiu realizar o sonho das gerações anteriores e que pretendia renegar um passado de fracassos em nome de um futuro de sucessos. Nascido em 1804, e portanto testemunha de todo o processo do Risorgimento desde o final da era napoleônica, Cantù não se conformava com esse "revisionismo histórico" imposto pelos nascidos após 1830. Ele reclama que os acontecimentos de ontem "parecem esquecidos" em um país que por eles não mais se interessa. "Por isso", ele afirma, "desejamos apresentar aqui as origens de um movimento literário que era também político e que naufragou, quem sabe?, por culpa daqueles que deveriam um dia conduzi-lo a um porto seguro." 138

É possível inferir que as ideias românticas provenientes da Alemanha e introduzidas na Itália por II Conciliatore foram determinantes para uma aglutinação das diferentes correntes de pensamento que visavam a unificação da Itália gestadas no âmbito da ocupação francesa. Para Cantù, aqueles que leem o periódico, "ali encontram sentimentos e opiniões hoje comuns, porém raros então. Mas é justo avisar que os artigos tinham que ser escritos com cautela porque eram mutilados pela censura." De fato, II Conciliatore desde o seu primeiro número, ou melhor, desde a sua concepção, enfrentou problemas com a administração austríaca do Reino Lombardo-Vêneto. É bom lembrar que Pellico, Di Breme, Borsieri, Porro Lambertenghi e Confalonieri tiveram que esperar mais de um ano antes de obterem

\footnotetext{
${ }^{137}$ Cesare Cantù. II Conciliatori e i Carbonari, pp 2 e 3 (nossa tradução).

${ }^{138}$ Idem, p. 276 (nossa tradução).
} 
o aval governamental para a sua publicação. Segundo Cantù, as mutilações impostas pelos censores "davam lugar a discussões e a protestos mais eficazes que o próprio jornal." II Conciliatore oferecia aos seus leitores a oportunidade "de discutir, de informar-se sobre as novidades italianas e estrangeiras" e por isso as autoridades austríacas o qualificaram de subversivo e segundo Cantù "não estavam erradas." 139

Nossa hipótese de interpretação considera o movimento romântico italiano essencialmente político, característica que o difere de seus congêneres alemão, inglês e francês. O próprio Cesare Cantù endossa essa tese no título de sua obra ao chamar de carbonários os membros do grupo de II Conciliatore. A Carbonaria foi uma sociedade secreta surgida na região dos Alpes franceses em fins do século XVIII que pregava a abolição de toda forma de opressão política. Seus ritos de iniciação em muito lembravam a Paixão de Cristo: os neófitos tinham que beber um vinho tinto que representava o sangue dos tiranos e devotar sua vida à causa da liberdade, da igualdade e da fraternidade dos povos. A Carbonaria organizou-se primeiramente no sul da Itália entre militares de baixa patente que foram afastados do exército do Reino de Nápoles após a restauração dos Bourbon em 1802. Com a invasão napoleônica e a consequente ocupação francesa entre 1805 e 1814, houve uma intensa troca de ideias entre esses militares e grupos jacobinos franceses que se opunham ao império de Napoleão Bonaparte. Desses contatos nasceu, provavelmente, o sentimento de irmandade, tão caro às hostes militares, assim como o forte teor independentista que desde seus primórdios animou a carbonaria italiana. Com a queda de Joaquim Murat e a reintronização dos Bourbon após o Congresso de Viena muitos carbonários exilaram-se nos Estados do norte e do centro da Itália, difundindo as ideias da sociedade secreta. $O$ desejo de independência, ancorado em um exacerbado nacionalismo, que se opunha tanto ao imperialismo francês pré-1814 quanto ao imperialismo austríaco pós-1815 e favorecia um governo representante das tradições populares italianas encontrou um solo fértil na pequena burguesia e entre o baixo clero católico, o que explica o forte

\footnotetext{
${ }^{139}$ Idem, p. 35 (nossa tradução).
} 
teor cristão e patriótico da Carbonaria em terras peninsulares. Os carbonários italianos foram homens muito mais de ação do que de palavras, o que tornou a carbonaria italiana uma sociedade secreta de caráter mais militar do que civil, com rígidas estruturas hierárquicas e uma reelaboração doutrinária que visava antes de tudo a luta política por meio de ações concretas. Para os carbonários a carta constitucional era o único meio de conciliar a soberania do Povo com as aspirações da Monarquia, muito embora uma parcela significativa deles não descartasse a República. ${ }^{140}$

Segundo Cesare Cantù eram três os objetivos da Carbonaria: "10) $A$ destruição dos governos onde o poder supremo não esteja assentado na nação; $2^{\circ}$ ) a destruição da impostura religiosa; $3^{\circ}$ ) em particular a independência italiana, isto é, um só governo, mas constitucional." 141 É razoável supor que o ideário romântico (que propunha em termos culturais uma volta às raízes nacionais em contraponto à universalização da cultura classicizante; patrocinava uma revalorização da Religião em oposição ao ateísmo iluminista; e rejeitava radicalmente as práticas políticas do absolutismo monárquico) não estava muito distante desse programa. Consequentemente, como notou Ettore Li Gotti, "das aspirações sociais e civis às poéticas e patrióticas o passo era inevitável, tanto que todos os membros do grupo de II Conciliatore (i conciliatori), com o passar do tempo, revelaram-se férvidos patriotas e inflamados carbonários." ${ }^{142}$ Acrescentaríamos que essa militância, muito embora tenha sido expressa nas mutiladas páginas de I/ Conciliatore, dar-se-á em plenitude durante as revoluções liberais na década de 1820, portanto após o fechamento do jornal. Também é possível inferir que Cantù reporta-se a essa época do argumentar, em 1878, "pobre de nós se acreditássemos que a Liberdade nasceu ontem! Ela se nutre de tradições e nós escrevemos este episódio propriamente para eliminar o desprezo de muitos em relação a alguns momentos da nossa história." 143 É como se pudéssemos entender que Romantismo e Risorgimento estão intimamente ligados, uma vez que a introdução das ideias românticas na Itália veio aglutinar o ideal independentista e unificador gestado ao final do século XVIII.

\footnotetext{
${ }^{140}$ Renato Soriga. "Carboneria" in Enciclopedia Italiana di Scienze, Lettere ed Arti, volume VIII, pp 962-963.

${ }^{141}$ Cesare Cantù. Op cit, p 115 (nossa tradução).

${ }^{142}$ Ettore Li Gotti. G. Berchet - La letteratura e la politica del Risorgimento nazionale (17831851), p. 133 (nossa tradução).

${ }^{143}$ Cesare Cantù. Op cit, p. 222 (nossa tradução).
} 
Publicado em 1818, II Conciliatore vinha sendo elaborado em reuniões de seus idealizadores desde 1816. De acordo com Pier Angelo Menzio, "Pellico, Borsieri e Breme são os pioneiros nessa empreitada; Porro e Confalonieri os mecenas; os outros os seguiram." 144 Silvio Pellico nasceu em Salluzo, filho de uma modesta família, no dia 25 de junho de 1789 e morreu em Turim no dia 25 de janeiro de 1854. Aos vinte e poucos anos de idade estabeleceu-se em Milão, onde logo travou amizade com Ugo Foscolo. Sua tragédia em versos Francesca da Rimini granjeou-Ihe fama e reconhecimento desde sua estreia em 18 de agosto de 1815, e continuou a fazer sucesso nos palcos italianos por mais de meio século. Quando estourou em 1816 a polêmica entre românticos e classicistas Pellico, após alguma hesitação, alinhou-se entre os primeiros. Empregado como preceptor dos filhos do conde Luigi Porro Lambertenghi, conhecido agitador político, participou desde o início das reuniões que visavam a criação de um jornal literário que divulgasse as novas ideias que chegavam do exterior. Tornou-se então o editor responsável por II Conciliatore. Após o fechamento do jornal em 1819, Pellico escreveu outra tragédia, Eufemio di Messina (1820). Por essa época estreita relações com Pietro Maroncelli, que o introduz na Carbonaria. Com o fracasso da revolução liberal milanesa de 1820 Maroncelli é preso como conspirador e denuncia Pellico como um dos líderes do movimento. Inicialmente condenado à morte o poeta e dramaturgo viu sua pena ser reduzida a vinte anos de trabalhos forçados a ser cumprida na fortaleza de Spielberg, na Morrávia, onde ele deu entrada no dia 20 de abril de 1822. Depois das mudanças ocorridas no governo austríaco em 1830, teve sua pena comutada e, posto em liberdade, foi viver com a família em Turim. Doente e abatido pelos maus tratos sofridos na prisão, Pellico, filho de uma família religiosíssima que, como muitos de sua geração, havia negligenciado a Religião, reencontrou sua fé na solidão do cárcere. Já em liberdade foi incentivado por sua mãe e por seu confessor a escrever um relato de sua vida como prisioneiro mostrando como a Fé o ajudara a superar o Sofrimento. Lançado no início de novembro de 1832 Le mie prigioni dividiu os críticos: os católicos não se convenceram da sincera conversão de Pellico e alguns de seus antigos companheiros o acusaram de ter se tornado um carola. Mas é fato que o livro ficou imensamente popular entre os italianos, que nele encontraram a narrativa dos sofrimentos infligidos a um homem culto e sensível cujo

\footnotetext{
${ }^{144}$ Pier Angelo Menzio (org). Dal Conciliatore, p 18 (nossa tradução).
} 
único crime fora lutar pela liberdade de sua pátria. Traduzido em várias línguas sempre com o mesmo sucesso de público, Le mie prigioni tornou-se um libelo contra a opressão de um povo por um ocupante estrangeiro e um poderoso instrumento de propaganda da independência da Itália. Em 1834 Pellico escreveu I doveri degli uomini, obra profundamente católica que serviu para apaziguar aqueles difidentes em sua conversão e afastá-lo de vez daqueles discordantes de seu novo posicionamento ideológico. Quando dos distúrbios revolucionários de 1848, ele apoiou com entusiasmo as lutas pela independência, mas reprovou alguns excessos demagógicos. Muito embora considerado, durante todo o século XIX, o maior tragediógrafo italiano depois de Vittorio Alfieri sua obra dramática não resistiu à passagem do Tempo e esvaeceu junto com a sensibilidade romântica que tão bem representava. Hoje Silvio Pellico é ainda lembrado como o autor de Le mie prigioni, o eterno grito daqueles que sofrem as agruras da luta pela Liberdade. ${ }^{145}$

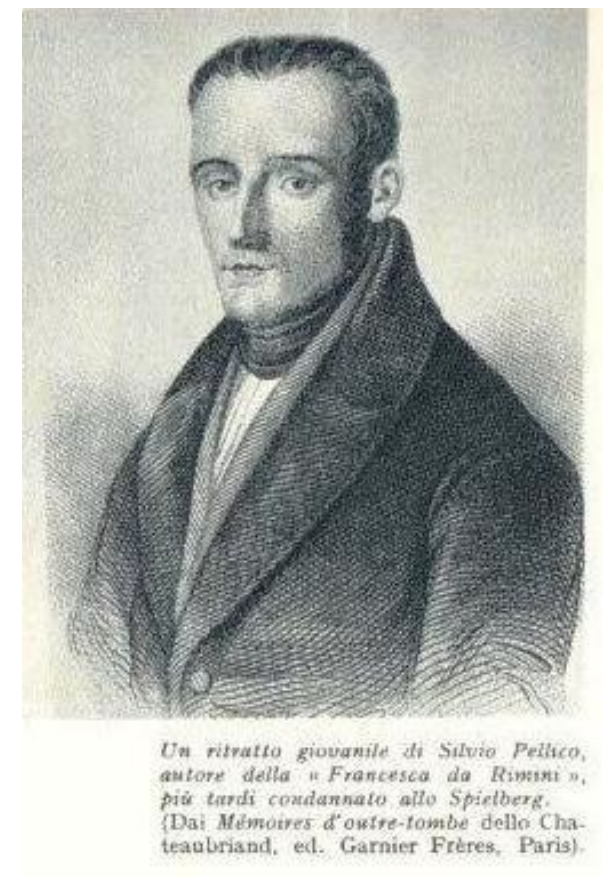

Retrato de Silvio Pellico quando jovem (in Cesare Spellanzon.

Storia del Risorgimento e dell'unità d'Italia, p. 612)

Pietro Borsieri nasceu em Milão em 1786 e morreu em Belgirate no dia 5 de agosto de 1852. Filho de um alto magistrado, graduou-se em Direito na Universidade de Pavia. Foi empregado do Ministério da Justiça do Reino da Itália e

\footnotetext{
${ }^{145}$ Egidio Bellorini. "Pellico, Silvio" in Enciclopedia Italina di Scienze, Lettere ed Arti, volume XXVI, pp 633-635.
} 
após a restauração de 1815 trabalhou no Tribunal de Justiça de Milão. Nos processos decorrentes da revolução de 1820 foi condenado à morte, mas sua pena foi abrandada para vinte anos de trabalhos forçados na fortaleza de Spielberg. Anistiado em 1836 emigrou para os Estados Unidos, lá permanecendo por um curto período de tempo. Retornou a Milão depois da anistia geral promovida pelo governo austríaco. Desde jovem Borsieri foi ligado à Literatura, sendo considerado um arauto do Romantismo na Itália, muito em função de seu ensaio Avventure litterarie di un giorno (1816) e de sua ativa participação nas páginas de II Conciliatore, do qual é autor do programa lançado antes do primeiro número. ${ }^{146}$

Ludovico Arborio Grattinara, marquês de Breme, ou simplesmente Ludovico di Breme, nasceu em Turim em 1780 e ali faleceu no dia 15 de agosto de 1820 . Eclesiástico, sua carreira esteve sempre ligada ao bonapartismo: foi esmoler do Vice-Rei Eugênio Beauharnais, sobrinho de Napoleão; governador da casa dos pajens do Reino da Itália; conselheiro de Estado e cavaleiro da Coroa de Ferro. Após a queda de Bonaparte, Di Breme permaneceu em Milão, vigiado porém respeitado pelos austríacos. Tomou o partido do Romantismo quando publicou Intorno all'ingiustizia di alcuni giudizi letterari italiani (1816) e participou das primeiras reuniões que idealizaram II Conciliatore, cujo nome teria sido sugestão sua. Ludovido di Breme sempre defendeu abertamente Napoleão Bonaparte, posicionou-se contra o academicismo literário e foi crítico feroz da hipocrisia religiosa. Em seus escritos o Romantismo é considerado um movimento libertador das velhas formas estéticas e um impulso criativo às Artes. Silvio Pellico, Madame de Staël, Lord Byron, August Wilhelm Schlegel e Stendhal estão entre aqueles que deixaram um retrato de Ludovico di Breme como uma das figuras mais características e vivazes do romantismo italiano no princípio do século XIX. ${ }^{147}$

Falemos agora dos mecenas do nosso jornal. Luigi Porro Lambertenghi nasceu em Como no ano de 1780 e morreu em Milão no dia 9 de fevereiro de 1860. Mais conhecido como Conde Porro, era membro de uma antiga família de nobres lombardos. Estreou na política como deputado de Como à Assembleia de Lyon em 1801 e no ano seguinte integrou o corpo legislativo da República Italiana até a sua dissolução após a derrota francesa. Participou da administração pública do Reino

\footnotetext{
${ }^{146}$ Egidio Bellorini. "Borsieri, Pietro" in Enciclopedia Italiana di Scienze, Lettere ed Arti, volume VII, p. 531.

${ }_{147}$ Carlo Calcaterra. "Breme, Ludovido di" in Enciclopedia Italiana di Scienze, Lettere ed Arti, volume VII, p. 799.
} 
da Itália e depois da derrota definitiva de Napoleão Bonaparte passou a defender fervorosamente a independência da Península. Rico empreendedor, a Porro Lambertenghi se deve a introdução das primeiras máquinas de fiar a vapor na Lombardia, o desenvolvimento da iluminação a gás, a fundação de escolas e a construção de navios a vapor. Foi em sua casa que se realizaram as reuniões preparatórias para a concepção e o lançamento de II Conciliatore, que ele apoiou financeiramente e com o qual contribuiu com artigos técnicos sobre agricultura e engenharia hidráulica. Após a prisão de Silvio Pellico, preceptor de seus dois filhos, devida aos desdobramentos do fracassado levante de 1820, Porro, notório carbonário, fugiu para a Inglaterra. Ele foi condenado a morte, à revelia, no dia 20 de abril de 1822. Em seu exílio na Grã-Bretanha juntou-se a Ugo Foscolo e a outros patriotas na divulgação da causa italiana. Em 1825, Porro Lambertenghi viajou à Grécia para lutar ao lado dos independentistas gregos, desempenhando várias missões militares. Dois anos depois, em 1827, vamos encontrá-lo gravemente enfermo em Marselha, onde vive em retiro absoluto. Com a anistia geral de 1838 ele pôde retornar à Itália, mas o fez apenas em 1840. O conde Luigi Porro Lambertenghi foi um dos poucos patriotas de 1820 que viveram para ver a expulsão definitiva dos ocupantes estrangeiros da Itália. ${ }^{148}$

O outro mecenas de II Conciliatore foi o conde Federico Confalonieri, um aristocrata dedicado à vida política. Ele nasceu em Milão no dia 6 de outubro de 1785 e faleceu em Hospenthal no dia 10 de dezembro de 1846. Muito embora fosse casado desde 1806 com Teresa Casati, dama de companhia da Vice-Rainha da Itália, Amália Augusta, Confalonieri recusou-se a fazer parte da corte do Vice-Rei Eugênio porque não concordava com a ocupação francesa da Lombardia. Após a queda de Napoleão Bonaparte nosso conde foi escolhido pelo senado lombardo membro da deputação italiana enviada ao Congresso de Viena em abril de 1814. Pôde então apelar pessoalmente ao Imperador da Áustria e ao Príncipe de Metternich em favor da independência da Itália. Na sequência dos acontecimentos que dividiram o Reino da Itália e incorporaram a Lombardia ao Reino LombardoVêneto, Confalonieri participou de iniciativas que visavam o desenvolvimento econômico de sua terra natal, tais como a introdução da navegação fluvial a vapor, da iluminação a gás, das escolas de mútuo-ensinamento e a publicação de II

\footnotetext{
${ }^{148}$ Aldo Romano. "Porro Lambertenghi, Luigi" in Enciclopedia Italiana di Scienze, Lettere ed Arti, volume XXVII, p. 952.
} 
Conciliatore. Não enxergando porém outro caminho para a independência do que a luta armada contra a Áustria, ele uniu-se aos carbonários e chegou à liderança da Carbonaria no norte da Itália. Com o fracasso do levante de 1820, Confalonieri foi preso no dia 13 de dezembro de 1821 acusado de alta traição. Seu processo estendeu-se até o fim de 1823 e terminou com sua condenação à morte. A sentença foi posteriormente reformulada para prisão perpétua com trabalhos forçados e por isso ele partiu, em 5 de fevereiro de 1824, para Spielberg. Conta-se que em sua passagem por Viena Confalonieri teve uma audiência privada com Metternich, que Ihe ofereceu um abrandamento de sua pena em troca de algumas delações, o que ele prontamente recusou. Ficou preso em Spielberg até 1835 quando o novo Imperador da Áustria, Fernando, o anistiou sob a condição de jamais voltar a por os pés em terras de seu império. ${ }^{149}$

Já discorremos sobe os idealizadores de II Conciliatore (Pellico, Borsieri e Di Breme) e sobre seus mecenas (Porro Lambertenghi e Confalonieri), voltemos agora nossa atenção para seus colabores. O primeiro número da "Folha Azul" (Foglio azzurro) ganhou as ruas na quinta-feira 3 de setembro de 1818. No dia 17 de outubro do mesmo ano Silvio Pellico escreveu de Milão uma cara para Ugo Foscolo, seu grande amigo que, por razões políticas, na época estava exilado em Londres.

Te mando os números do Conciliatore que saíram até agora (...) - G. R. é Rasori; - G. D. R. Romagnosi; - L. D. B. Breme; B. Borsieri; - Grisostomo é Berchet; G. P. é Giuseppe Pecchio; - Cristoforo Colombo II é o irmão de Pecchio. - Tem eu: tem o professor Ressi; - S. S. é Sismondi de Genebra, etc. (...). Por que (perguntará você) deram esse título para o jornal? Porque nos propomos a conciliar, e na verdade conciliamos, não os leais com os falsos, mas todos os sinceros admiradores do Verdadeiro. $O$ público já percebe que este não é um empreendimento de mercenários, mas de literatos, se não todos famosos, todos unidos para manter, até onde for possível, a dignidade do nome italiano. ${ }^{150}$

À guisa de esclarecimento diremos que os nomes dos autores apareciam em iniciais ao pé dos artigos publicados e por isso Pellico teve que indicar a Foscolo quais eram as pessoas que tais iniciais anunciavam, ou escondiam, uma vez que o jornal era vítima de severa censura da parte do governo austríaco. É bom lembrar

${ }^{149}$ Giuseppe Gallavresi. "Confalonieri, Federico" in Enciclopedia Italiana di Scienze, Lettere ed Arti, volume XI, p. 114.

${ }^{150}$ Silvio Pellico. Epistolario, p. 20 (nossa tradução). "Ti mando le copie finora uscite del Conciliatore (...) - G. R. è Rasori; G. D. R. Romagnosi; - L. D. B. Breme; B. Borsieri; - Grisostomo è Berchet; - G. P. è Giuseppe Pecchio; - Cristoforo Colombo II è il fratello di Pecchio. - Vi sono io: v'è il professore Ressi; S.S. è Sismondi di Ginevra, ecc... - Perché (domanderai) un sifatto titolo al vostro giornale? Perché noi ci proponiamo di conciliare e conciliamo infatti - non i leali coi falsi, ma tutti i sinceri amatori del vero. Già il pubblico si acorge che questa non è impresa di mercenari, ma di letterati, se non tutti di grido, tutti collegati per sostenere, finché è possibile, la dignità del nome italiano." 
que as iniciais dos autores foram mantidas em todos os cento e dezoito números do periódico.

Giovanni Rasori nasceu em Parma no dia 20 de agosto de 1766 e morreu em Milão no dia 13 de abril de 1837. Graduado na Universidade de Pavia foi um dos mais importantes médicos italianos do final do século XVIII e início do século XIX. Estudou em Londres com alguns dos mais famosos cientistas da época, entre os quais J. Hunter. Em outubro de 1796, residente em Milão, foi nomeado reitor do Collegio Ghisleri e em dezembro daquele ano assumiu a cátedra de patologia médica da Universidade de Pavia. Da mesma época é a sua colaboração no milanês Giornale degli amici della Libertà e della Ugaglianza, difusor das ideias liberais da Revolução Francesa. Quando da primeira invasão francesa da Itália em 1797 e o estabelecimento, no território lombardo, da República Cisalpina, Rasori foi chamado a Milão para ser o secretário-geral do Ministério do Interior. Em 1798 ele retornou a Pavia e foi eleito por aclamação, aos 32 anos de idade, reitor da universidade local. No ano seguinte (1799) ele publicou o livro Sul preteso genio di Ippocrate, obra que causou estupor e indignação no meio universitário italiano e proporcionou a Rasori inúmeros inimigos de sua tese segundo a qual era necessário queimar todos os livros de medicina e adotar, na Itália, os novos princípios científicos defendidos pelo lluminismo. Ele lutou como voluntário do exército cisalpino ao lado de Ugo Foscolo, quando a república foi invadida pelas tropas austríacas. Em 1801, após ajudar no combate a uma epidemia de tifo ocorrida em Gênova, Rasori publicou o livro Istoria della febbre epidemica, uma espécie de crônica dos acontecimentos por ele vividos na luta contra a doença na Ligúria, que teve quatro edições milanesas, uma alemã e outra francesa. Com a vitória de Napoleão Bonaparte em Marengo foi-lhe oferecido o cargo de Ministro do Interior, que ele recusou preferindo assumir a chefia do serviço de saúde, onde organizou toda uma rede de assistência pública no norte da Itália. Em 1806 Rasori passou a lecionar clínica médica no Hospital de Milão, onde permaneceu até a dissolução do Reino da Itália. Preso por conspiração no dia 4 de dezembro de 1814 ficou encarcerado na Prisão de Mainolda, em Mantova, até 9 de março de 1817, quando foi transferido para Milão. Rasori só foi posto em liberdade em março de 1818. No cárcere ele traduziu várias poesias de Wieland e de Goethe, além da obra Intorno 
alla mimica, de Engel. ${ }^{151}$ Libertado, Rasori foi nomeado médico da corte de Catarina de Brunswick, então princesa de Gales e futura Rainha da Inglaterra. Mas ele preferiu continuar em Milão e passou a colaborar com II Conciliatore. Teve porém de afastar-se do jornal por ordem da polícia austríaca, que o considerava um elemento suspeito a ser mantido sob vigilância especial. ${ }^{152}$

Gian Domenico Romagnosi nasceu em Salsomaggiore no dia 11 de dezembro de 1761 e morreu em Milão no dia 8 de junho de 1835. Membro de uma família nobre ele primeiramente estudou no colégio dos jesuítas de Borgo di San Donnino entre 1772 e 1775, graduando-se em Parma no ano de 1786. Sob proteção paterna exerceu o tabelionato em Parma, sem sucesso, de 1787 a 1789. Retornando a Piacenza, Romagnosi adquiriu fama e prestígio nos meios forenses com a publicação, em 1791, do livro Genesi del diritto penale. Em setembro do mesmo ano mudou-se para Trento onde assumiu as funções de pretor, cargo que ocupou até 1793. Ele viveu em Trento, exercendo a advocacia, até 1802. Em 1799, após a expulsão dos franceses e o retorno dos austríacos, Roamgnosi foi preso, e passou quinze meses encarcerado em Innsbruck, acusado de abuso de autoridade quando foi pretor. Finalmente inocentado, foi posto em liberdade para grande júbilo da população trentina. Com a volta dos franceses em 1801 ele foi nomeado secretário do governo provisório, cargo que ocupou até 1802, quando obteve a cátedra de direito penal na Universidade de Parma. Foi na condição de professor universitário que ele publicou, em 1805, outra obra importante Introduzione allo studio del diritto pubblico universale. A recepção positiva do livro valeu a Romagnosi o convite feito pelo ministro da justiça do Reino da Itália (Luosi) para juntar-se ao grupo de jurisconsultos que, em 1806, elaborava o código de direito penal do Reino. Em 1807, ele demitiu-se da Universidade de Parma para assumir as funções de conselheiro do ministro da justiça e a cátedra de direito civil da Universidade de Pavia. Em 1808, Romagnosi transferiu-se para Milão onde passou a lecionar direito público-administrativo nas escolas especiais de políticas públicas por ele organizadas na capital do Reino da Itália. Entre 1808 e 1814 Romagnosi foi o inspirador do ordenamento jurídico do vice-reinado de Eugênio Beauharnais. Com a formação do Reino Lombardo-Vêneto, foi-Ihe permitido manter seus cursos de

\footnotetext{
${ }^{151}$ Resenhada pelo próprio Rasori no número 16 de II Conciliatore (25/10/1818).

${ }^{152}$ Mario Menghini. "Rasori, Giovanni" in Enciclopedia Italiana di Scienze, Lettere ed Arti, volume XXVIII, p. 851.
} 
legislação público-administrativa até setembro de 1817, quando as escolas especiais de políticas públicas foram fechadas pelo governo austríaco. Mesmo assim Romagnosi conseguiu autorização para lecionar privadamente. Foram seus alunos particulares Giuseppe Ferrari, Carlo Cataneo, Cesare Cantù, Giuseppe Sacchi, entre outros. Na sequência dos acontecimentos de 1820, Romagnosi foi preso em 1821 sob acusação de conspiração contra o governo. Enviado a Veneza, escreveu no cárcere a obra Insegnamento primitivo delle matematiche. Solto por falta de provas no dia 10 de dezembro de 1821, retornou a Milão. Porém a administração austríaca do Reino Lombardo-Vêneto retirou-Ihe a licença para lecionar, deixando-o, velho e adoentado, sem meios de subsistência. Quando em 1825 Romagnosi recebeu um convite do governo inglês para assumir a cátedra de jurisprudência teórica na Universidade de Corfú foi-Ihe negado o passaporte. Viveu então o iminente jurisconsulto da caridade de seus ex-alunos e de outros admiradores os últimos anos de sua vida. Dentre suas obras, além das já citadas, destacam-se Istituzioni di diritto amministrativo (1814), Dalla costituzione di una monarchia nazionale rappresentativa (1815) e Assunto primo della scienza del diritto naturale (1820). ${ }^{153}$

Giovanni Berchet nasceu em Milão no dia 23 de dezembro de 1783 e morreu em Turim no dia 23 de dezembro de 1851. Filho de pobres imigrantes da Suíça francófona desde muito jovem Berchet ganhou a vida como funcionário público. Aluno de Parini, amigo de Vincenzo Monti e de Ugo Foscolo esteve sempre envolvido em assuntos literários. Dominava as línguas inglesa, francesa e alemã e por isso traduziu para o italiano Gray (O Bardo), Goldsmith (O Vigário de Wakefield) e Schiller (O Visionário). Em 1816 ele publicou, em Milão, o opúsculo Sul Cacciatore feroce e sulla Eleonora di G. A. Bürger: Lettera semiseria di Grisostomo, que foi o gatilho da intensa polêmica entre românticos e classicistas que se estenderia por mais de uma década. Sua colaboração em II Conciliatore aproximou Berchet do conde Federico Confalonieri e da Carbonaria por ele liderada. Ativista na luta contra o governo austríaco do Reino Lombardo-Vêneto, nosso autor fugiu para a Suíça depois do fracasso da revolução liberal de 1820. Ele exilou-se em Londres, onde passou a trabalhar como tradutor para uma casa editora. Quando ainda estava em Milão Berchet escreveu o poema histórico-narrativo I profughi di

\footnotetext{
${ }^{153}$ Giole Solari. "Romagnosi, Gian Domenico" in Enciclopedia Italiana di Scienze, Lettere ed Arti, volume XXIX, p. 938.
} 
Parga, mas foi na capital britânica que ele viveu seu momento mais criativo. Ali ele escreveu seis romances: Clarina, II romito del Cenisio, Matilde, II trovatore, Giulia e Le fantasie, que apesar da censura austríaca obtiveram enorme sucesso na Itália. Expressão de um exacerbado romantismo, hoje em dia os livros de Berchet soam melodramáticos e as demonstrações de amor pátrio assim como as descrições pungentes da tristeza do exílio algo exageradas. Mas é preciso recordar que ele foi um dos mais populares autores italianos do século XIX. Em 1829, Berchet deixou Londres e passou a viver em Bruxelas na condição de preceptor dos filhos do marquês Giuseppe Arconati, um rico aristocrata exilado por questões políticas. A partir de então ele praticamente abandonou a Literatura, só voltando a publicar em 1847, perto do fim da vida, uma tradução italiana de uma seleção de poesias espanholas, acompanhada de um precioso estudo introdutório. ${ }^{154}$

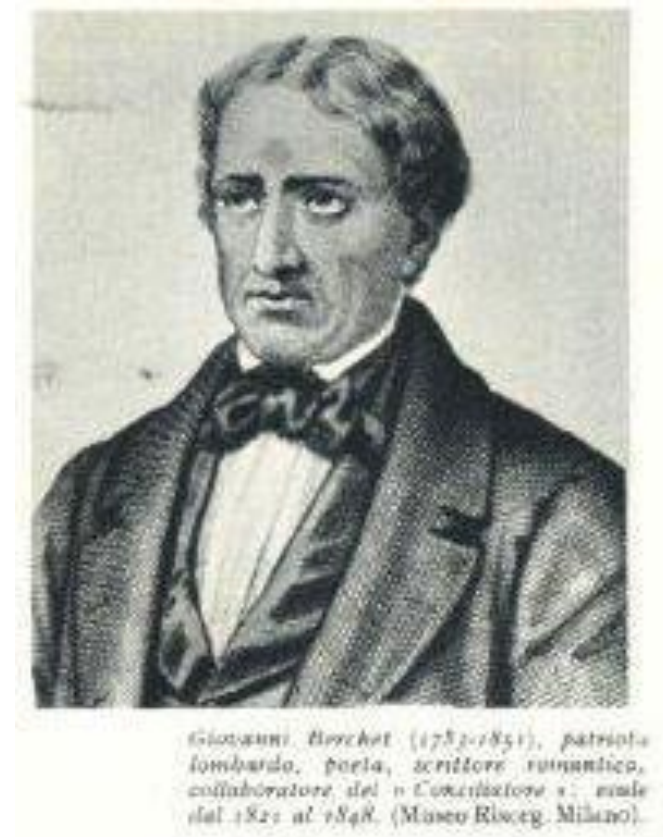

Giovanni Berchet (1783-1851). Patriota lombardo, poeta, escritor romântico, colaborador de Il Conciliatore. Exilado entre 1821 e 1848. (in Cesare Spellanzon. Storia del Risorgimento e dell'unità d'Italia, p. 771)

Giuseppe Pecchio nasceu em Milão no dia 15 de novembro de 1875 e morreu em Brighton, na Inglaterra, no dia 10 de março de 1835. Foi ouvidor do Conselho de Estado do Reino da Itália entre 1810 e 1814. Com a volta dos austríacos após o Congresso de Viena Pecchio engajou-se na oposição liberal ao Reino LombardoVêneto e teve participação ativa no levante de 1820. Não chegou a ser preso

\footnotetext{
${ }^{154}$ Egidio Bellorini. "Berchet, Giovanni" in Enciclopedia Italiana di Scienze, Lettere ed Arti, volume VI, p. 690. Um estudo mais completo sobre Berchet é referido na nota 142.
} 
porque fugiu para o estrangeiro. Viveu então em Brighton, onde faleceu sem jamais retornar à Itália. Entre suas obras destacam-se Vita di Ugo Foscolo (1830) e Storia critica della poesia inglese (1835). Pecchio obteve reconhecimento póstumo por dois livros de história econômica: Saggio storico sulla amministrazione finanziaria dell'ex Regno d'Italia, publicado em Londres em 1830, e principalmente pela Storia della economia pubblica in Italia, o primeiro estudo do gênero escrito em italiano. ${ }^{155}$

O conde Adeodato Ressi nasceu em Cervia, na província de Ravenna, no dia 4 de setembro de 1768 e morreu nos cárceres de Veneza no dia 18 de janeiro de 1822. Ele já havia concluído sua graduação em direito na Universidade de Pavia quando Napoleão Bonaparte realizou sua primeira campanha militar no norte da Itália. Com a ocupação francesa da Emilia e da Romagna, Ressi participou do governo da região de Ravenna e Forlì, que não havia sido anexada à República Cispadana, e posteriormente, em novembro de 1797, foi escolhido como deputado ao Parlamento da República Cisalpina, onde notabilizou-se nas discussões sobre políticas econômico-financeiras. Em dezembro de 1800, Ressi foi nomeado professor de economia política na Universidade de Pavia, e com a instauração do Reino da Itália ele passou a fazer parte de seu conselho diretivo e foi também eleito para o Colégio dos Doutos de Bolonha. Após a restauração austríaca em 1815, Ressi continuou lecionando em Pavia, onde publicou entre 1817 e 1819 os quatro volumes da obra Dell'economia della specie umana ${ }^{156}$, que the granjearam imensa fama em toda a Europa. Porém no verão de 1818 ele foi demitido da universidade por ordem do governo do Reino Lombardo-Vêneto e a cátedra de economia política foi suprimida em Pavia. Nos desdobramentos da revolução liberal milanesa, Ressi foi preso em Pavia no dia 29 de junho de 1821 após ser denunciado como conspirador. Transferido para Veneza, ele foi encarcerado na llha de São Miguel. Em 6 de dezembro de 1821 foi condenado a prisão perpétua, comutada em seis anos de trabalhos forçados de acordo com uma sentença de 21 de fevereiro de 1822. No entanto, o prisioneiro, que adentrara o cárcere em péssimas condições de

\footnotetext{
${ }^{155}$ Pietro Vaccari. "Pecchio, Giuseppe" in Enciclopedia Italiana di Scienze, Lettere ed Arti, volume XXVIII, p. 570

${ }^{156}$ Os volumes I e II dessa obra de Adeodato Ressi foram resenhados em quatro artigos publicados em II Conciliatore. Ver os números 38 (10/01/1819), 41 (21/01/1819), 48 (14/02/1819) e 50 (21/02/1819). A inicial A., com que o articulista assina, não foi identificada por Pier Angelo Menzio em Dal Conciliatore (1927), a principal fonte acerca da estrutura do jornal.
} 
saúde, não resistira ao inverno e morrera em 18 de janeiro. Adeodato Ressi é considerado mártir da independência italiana. ${ }^{157}$

O correspondente estrangeiro de II Conciliatore foi o historiador, literato e economista Jean-Charles-Léonard Sismonde de Sismondi. Ele nasceu em Genebra no dia 9 de maio de 1773 e morreu no dia 25 de junho de 1842. Completou seus estudos na cidade natal, que teve de deixar em 1793 por razões políticas. Exilado na Inglaterra, Sismondi não teve grandes dificuldades em assimilar a língua, a cultura e os costumes britânicos e acabou por escrever An abstract of the constitution of England. A partir de 1795 ele passou a residir na Toscana, na vila de Valchiusa, nos arredores de Pescia. Não demorou muito para que Sismondi fosse identificado como jacobino, tendo sido preso duas vezes: em 1796 e em 1799. Assim como havia ocorrido na Inglaterra, Sismondi interessou-se sobremaneira pelos hábitos e pelos costumes toscanos, e retornando a Genebra em 1801 ele publicou um livro chamado Tableau de l'agriculture toscane. Tal obra granjeou-lhe uma grande fama como economista e lhe valeu a nomeação para o cargo de secretário do Conselho de Comércio, Artes e Agricultura do Departamento de Lemano. É a partir de então que surgem suas grandes obras. Como historiador, ele escreveu a fundamental Histoire des républiques italiennes du moyen age, cujos primeiros quatro volumes saíram em Zurique entre 1807 e 1808 . Os demais dezesseis foram publicados em Paris de 1809 a 1818. Nessa obra Sismondi defende duas concepções de História: na primeira a História é pensada como desenvolvimento dos povos no caminho da Liberdade, e na segunda a História é determinada pelos governos e pelas instituições. A tese central é que a Itália foi grande enquanto manteve instituições e governos livres e decaiu quando se submeteu aos interesses da lgreja e de potências estrangeiras. Ao responsabilizar os príncipes e os eclesiásticos pela decadência italiana Sismondi ofereceu um instrumento teórico importante para a luta anti-aristocrática e anti-clerical empreendida pelos românticos no campo do liberalismo político, já que concebeu a História como o processo de luta contra a tirania dos príncipes em favor da liberdade dos povos, e por isso essa obra é considerada um marco na formação da consciência liberal-nacional na Itália. Em seguida Sismondi escreveu os trinta e um volumes da sua Histoire des Français, publicados entre 1821 e 1844 (o último

\footnotetext{
${ }^{157}$ Mario Menghini. "Ressi, Adeodato" in Enciclopedia Italiana de Scienze, Lettere ed Arti, volume XXIX, p. 126. Esse verbete inicia-se com a frase definidora: "Patriota e mártir."
} 
contém uma tábua cronológica e o penúltimo não é de sua autoria). O propósito da nova historiografia romântica aparece já no título: não a história do território ou da monarquia, mas a história da nação e do povo franceses. Essa obra representou uma transformação historiográfica na medida em que procurou mostrar como os aspectos econômicos influem no comportamento dos povos e determinam a moral de seus governantes. No campo literário Sismondi é até hoje considerado um dos fundadores da crítica romântica, com sua obra De la littérature du Midi de I'Europe, cujos quatro volumes foram publicados em Paris em 1813. ${ }^{158}$ Aqui ele defende a tese que as peculiaridades e a formação histórica de cada povo determinam sua produção artística e vai contra a ideia clássica de uma arte universal baseada nos princípios estéticos da Antiguidade. Sismondi foi considerado um gênio pelos românticos italianos e teve no grupo de II Conciliatore seus primeiros seguidores na Itália. ${ }^{159}$

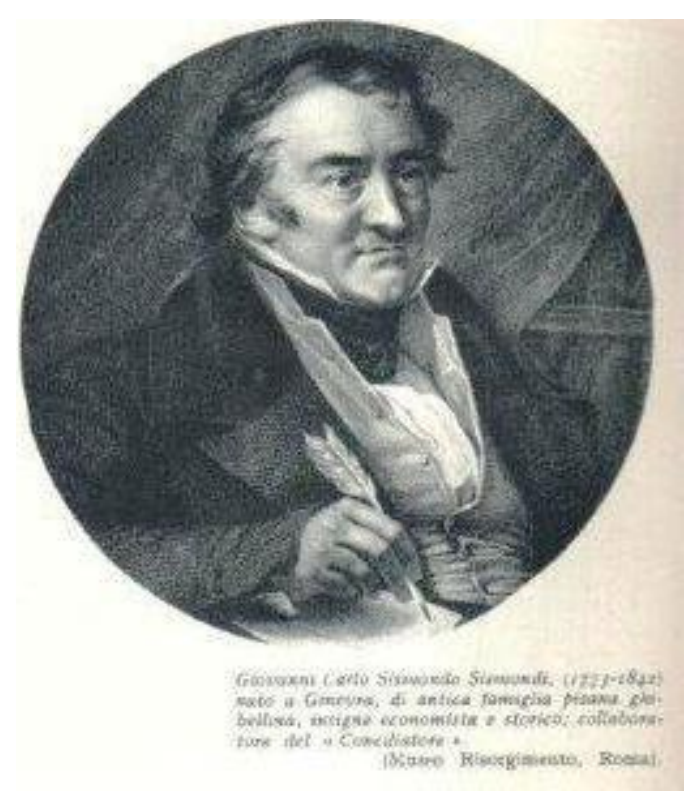

Giovanni Carlo Sismondo Sismondi (1773-1842). Natural de Genebra, de antiga família pisana e gibelina. Famoso historiador e economista, foi colaborador de Il Conciliatore (in Cesare Spellanzon.

Storia del Risorgimento e dell'unità d'Italia, p. 770).

${ }^{158}$ É preciso ressaltar que Sismondi, ao analisar no quarto volume de sua obra a literatura portuguesa, foi o primeiro a incluir em sua crítica autores nascidos no Brasil. Para uma explanação mais ampla dos laços de Sismondi com a literatura de língua portuguesa consultar a obra de Guilhermino César indicada na bibliografia.

${ }^{159}$ Walter Maturi. "Sismondi, Jean Charles Léonard Sismonde de" in Enciclopedia Italiana Di Scienze, Lettere ed Arti, volume XXXI, pp 920-921. Sismondi também publicou livros de economia, sendo reconhecido como o introdutor, na Europa, das ideias liberais dos economistas ingleses. Não avançamos nesse campo por considerá-lo fora da área de nosso estudo. 
Giuseppe Nicolini nasceu em Brescia no dia 20 de janeiro de 1788 e lá morreu no dia 24 de julho de 1856. Graduado em Direito, Nicolini lecionou no ginásio de Brescia e no liceu de Verona. Acusado em 1821 de ser carbonário foi preso e perdeu sua cátedra. Poeta, escreveu em versos La musa romantica, traduziu alguns poemas de Byron e a tragédia Macbeth de Shakespeare. Sua obra em prosa consiste em uma biografia de Byron (1834), que obteve um relativo sucesso na Itália, nas biografias de Walter Scott e de Robespierre além dos três volumes de Ragionamenti sulla storia di Brescia. ${ }^{160}$

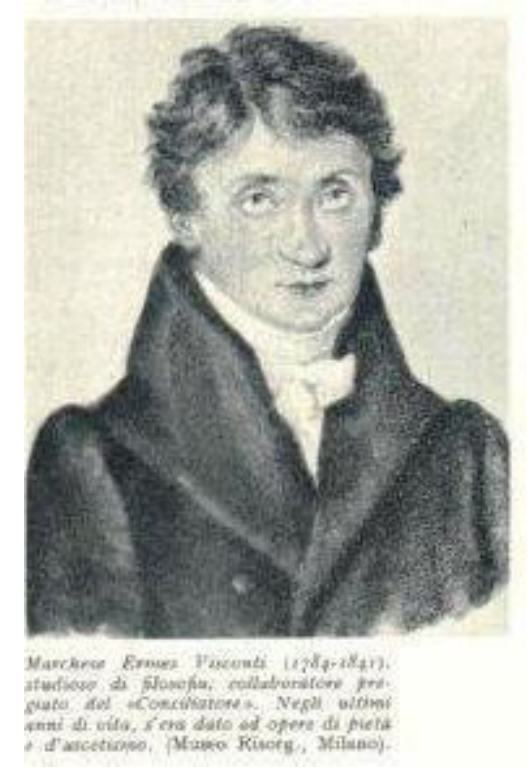

Marquês Ermes Visconti (1784-1841). Estudioso de Filosofia, importante colaborador de Il Conciliatore. Em seus últimos anos de vida dedicou-se a obras piedosas e ao ascetismo. (in Cesare Spellanzon.

Storia del Risrogimento e dell'unità d'Italia, p. 772)

Ermes Visconti nasceu em Milão no dia 15 de março de 1784 e morreu em Crema no dia 21 de janeiro de 1841. Ele foi um dos mais ativos colaboradores de II Conciliatore, onde redigiu artigos, opúsculos e outras contribuições várias que o tornaram um dos grandes fautores da escola romântica na Itália. Visconti escreveu as Idee elementari sulla poesia romantica, que apareceram em seis números do nosso jornal em 1818. ${ }^{161}$ Nesse conjunto de ensaios ele procura esclarecer e definir quais são as diferenças entre Romantismo e Classicismo, colocando as bases teóricas para o desenvolvimento da doutrina romântica em terras

\footnotetext{
${ }^{160}$ Egidio Bellorini. "Nicolini, Giuseppe" in Enciclopedia Italiana di Scienze, Lettere ed Arti, volume XXIV, p. 791.

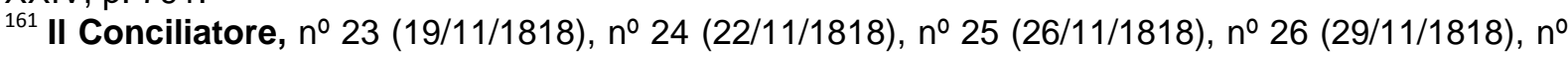
27 (03/12/1818), ํo- $28(06 / 12 / 1818)$.
} 
peninsulares. No ano seguinte, 1819, também em II Conciliatore, Visconti publicou o Dialogo sulle unità drammatiche di luogo e di tempo. ${ }^{162}$ Os pósteros, muito embora reconhecendo Visconti como o primeiro italiano a tratar dessas questões estéticas com uma visão romântica, o julgaram um filósofo medíocre e um crítico pouco inspirado. De sua autoria podemos ainda citar Saggi Filosofici (1829), Riflessioni ideologiche intorno al linguaggio grammaticale dei popoli antichi (1831) e Saggi intorno ad alcuni quesiti concernenti il Bello (1833) ${ }^{163}$

Nossa hipótese de interpretação é que os membros do grupo de II Conciliatore podem ser enquadrados dentro da categoria definida pelo historiador britânico Eric J. Hobbsbawn como "filo-jacobinismo". De acordo com ele "o valor militar do filo-jacobinismo estrangeiro foi principalmente o de um auxílio para a conquista francesa e uma fonte de administradores politicamente confiáveis para os territórios conquistados." 164 É possível inferir pelos dados biográficos apresentados acima que os colaboradores de nosso jornal estiveram ligados à administração do Reino da Itália. Porém é preciso buscar as origens do movimento "patrióticojacobino", como o chamou Giorgio Candeloro, nos anos 1790, ou seja, na década imediatamente posterior à Revolução Francesa, de 1789. Para a geração anterior àquela de que tratamos até agora, "rapidamente se coloca o problema do 'ressurgimento' da Itália em termos revolucionários, e não apenas no sentido de uma renovação cultural e moral, que havia sido proposta pelos iluministas", mas cria-se uma consciência de que somente, como nota Candeloro, "uma subversão do ordenamento político e em parte do ordenamento social" então existente poderia realmente levar à criação de um estado-nação independente. ${ }^{165}$ Segundo Stuart J. Woolf, "o que distinguia claramente os jacobinos dos reformadores iluministas da geração anterior era a ideia política da independência italiana como um passo necessário para a criação de uma sociedade completamente nova, na Itália e no resto do mundo." 166 Para Candeloro é interessante que o movimento filo-jacobino italiano "se estendesse também às cidades de província e que compreendesse,

\footnotetext{
${ }^{162}$ II Conciliatore, no 42 (24/01/1819) e no 43 (28/01/1819).

${ }^{163}$ Mario Marcazzan. "Visconti, Ermes" in Enciclopedia Italiana di Scienze, Lettere ed Arti, volume XXXV, p. 445. Talvez por não ter se envolvido nos conflitos políticos das décadas de 1820 e 1830 Visconti não é citado na obra de Cesare Cantù II Conciliatore e i Carbonari.

${ }^{164}$ Eric J. Hobbsbawn. A Era das Revoluções, p. 200.

165 Giorgio Candeloro. Storia dell'Italia moderna, volume I, Le origini del Risorgimento (17701815), p. 175 (nossa tradução).

${ }^{166}$ Stuart J. Woolf. "La storia politica e sociale" in Ruggiero Romano e Corrado Vivanti (org). Storia d'Italia, volume terzo, Dal primo Settecento all'Unità, p. 167 (nossa tradução).
} 
junto ao núcleo principal formado em essência por burgueses, elementos provenientes das massas populares citadinas (artesãos, em especial) de um lado e da aristocracia de outro." 167 À guisa de esclarecimento diremos que após a incorporação da península ao Império Napoleônico, em 1805, esta foi dividida em dois reinos: o Reino de Nápoles ao sul e o Reino da Itália ao norte. O primeiro era governado pelo rei Joaquim Murat, cunhado de Napoleão Bonaparte; o segundo tinha por rei o próprio imperador corso, mas era administrado pelo vice-rei Eugênio Beauharnais, seu sobrinho. A capital do reino ao sul era Nápoles e a do reino ao norte era Milão. Nesse contexto político de acordo com Stuart J. Woolf, "em todas as regiões da Itália foi criada uma ampla classe de funcionários, à qual se ascendia por mérito pessoal e não mais por razões hereditárias." 168 Segundo Giorgio Candeloro, nos dois reinos italianos formou-se "na era napoleônica uma classe de funcionários, de magistrados, de oficiais com origens aristocráticas, alguns, burguesas, outros, composta por homens capazes e desejosos de ampliar sua influência." Para o historiador, a burguesia provincial, que havia se desenvolvido de forma notável com as políticas públicas dos reformadores iluministas, "recebeu um grande impulso com as reformas do decênio francês." ${ }^{169}$ Acrescentaríamos que a grande diferença entre a Itália do período iluminista e aquela do período pós Revolução Francesa é o aumento do poder político dos pequenos proprietários rurais e dos extratos médios urbanos (comerciantes, artesãos). Como observou Stuart J. Woolf, "à diferença do período do despotismo iluminado, durante o qual as reformas foram frequentemente obstruídas ou sabotadas devido à hostilidade das classes proprietárias, no decênio 1805-1815 estas colaboraram com as autoridades governamentais, mesmo porque Napoleão, ao destruir os privilégios feudais, reforçou a posição social de tais classes." 170 É interessante notar que durante o domínio napoleônico na Itália houve, nas palavras de Giorgio Candeloro, "uma evolução social e política que em parte deu continuidade àquela do período revolucionário, em parte se conectou à era do absolutismo e em parte apresentou novas características que se desenvolveram na época da Restauração." ${ }^{171}$ De tudo isso seria razoável supor que II Conciliatore representou, na figura de seus

\footnotetext{
${ }^{167}$ Giorgio Candeloro. Op cit, p. 190.

${ }^{168}$ Stuart J. Woolf. Op cit, p. 218.

${ }^{169}$ Giorgio Candeloro. Op cit, p. 336

${ }^{170}$ Stuart J. Woolf. Op cit, pp. 217-218

${ }^{171}$ Giorgio Candeloro. Op cit, p. 293.
} 
idealizadores e de seus colaboradores, esse extrato reformador da sociedade italiana que foi alçado às esferas do poder público durante a ocupação francesa e que após a restauração austríaca ao norte e da volta dos Bourbon ao trono de Nápoles, ao sul, não teve outra alternativa a não ser lutar por uma Itália una e independente. Sabemos que eram de origem aristocrática Di Breme, Porro Lambertenghi, Confalonieri, Romagnosi, Ressi e Visconti; e burgueses Pellico, Borsieri, Rasori, Berchet, Pecchio e Nicolini. Muitos deles nasceram em pequenas cidades e todos fizeram carreira durante o governo do vice-rei Eugênio. É possível inferir que desde o começo II Conciliatore se propunha uma renovação da cultura italiana tendo como norte um ordenamento político muito distinto daquele oferecido pelo Império Austríaco, e por isso também não se pode negar que na Itália o Romantismo, desde sua gênese, foi um movimento político. Desde seus primórdios ser romântico era ser italiano.

No dia $1^{\circ}$ de julho de 1818 apareceu em Milão um impresso de três páginas com o cabeçalho "Il Conciliatore, foglio scientifico-letterario... Rerum concordia discors" e logo abaixo impresso com letras em caixa-alta lia-se "PROGRAMMA". No alto da página 3 anunciava-se "o primeiro número do Conciliatore no próximo dia 3 de setembro. Esse jornal sairá duas vezes por semana, às quintas-feiras e aos domingos precisamente ao meio-dia." 172 Explica-se a seguir qual será o formato da nova publicação: "Ele será composto de quatro páginas de duas colunas cada uma, na forma e caráter deste programa (...)" ${ }^{173} \mathrm{E}$ informava ao público "o papel terá as dimensões e a qualidade do presente, mas será de uma cor um tanto quanto cerúlea." 174 Isso por que o "Programma" fora impresso em folhas brancas. Dizia-se que o preço de assinatura do jornal seria de vinte e uma liras anuais e que os responsáveis comprometiam-se com o envio "em todo o Estado Lombardo até as fronteiras com o exterior." ${ }^{175}$ A assinatura era dividida em duas prestações

\footnotetext{
172 "Programma" in II Conciliatore, p. III (nossa tradução). "II primo numero del Conciliatore comparirà il giorno 3 di settembre prossimo venturo. Questo foglio uscirà due volte per settimana, nei giorni Giovedì e Domenica precisamente a mezzodi."

${ }^{173}$ Idem. "Esso sarà composto di quattro pagine di due colonne ciascuna, nella forma e carattere di questo Programma (...)"

${ }_{174}$ Idem. "La carta sarà della dimensione e qualità della presente, ma di colore alquanto ceruleo."

${ }^{175}$ Idem. "(...) in tutto lo Stato Lombardo, e fino ai confini per l'estero."
} 
semestrais, mas aceitavam-se também assinaturas para seis meses. Tanto as assinaturas anuais quanto as semestrais deveriam ser pagas antecipadamente. Escritores que desejassem publicar seus artigos em II Conciliatore deveriam remetê-los, às suas próprias custas, ao editor mencionado ao final do texto (Vincenzo Ferrario, contrada di s. Vittore e 40 martiri, nº 880). Interessante que por último dizia-se todos os literatos que quisessem ver suas obras anunciadas em II Conciliatore deveriam enviar um exemplar das mesmas, às suas próprias custas, ao Editor e que esses exemplares "vinham sempre restituídos aos respectivos autores, seja no caso de que os redatores anunciem-nos, seja que achem melhor deles não se pronunciarem." 176

Passemos agora a analisar o texto de Pietro Borseri. Logo no início somos

IL CONGILIATORE FOG L 10 SCIENTIFICO-LETTERARIO . Rerum concordia discors. PROGRAM

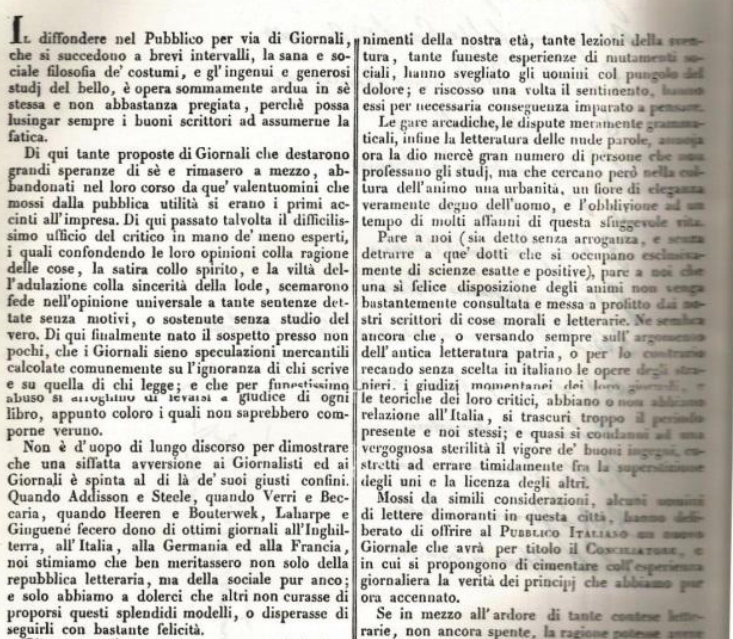
informados de que a feitura de um jornal é uma empreitada "altamente árdua e não tanto reconhecida" a ponto de motivar "os bons escritores" a empreendê-la. ${ }^{177}$ Por isso a missão de informar o público acabou nas mãos de pessoas incompetentes que, "confundindo suas opiniões com a razão das coisas, a sátira com o espírito e a baixeza da adulação com a sinceridade do elogio" ${ }^{178}$, afastaram da leitura dos jornais as pessoas de bom gosto. De acordo com Borsieri, na Itália de trinta anos antes (ou seja, na década de 1780) o saber circulava em restritos grupos de acadêmicos, que se autoelogiavam e promoviam-se uns aos outros. Segundo ele, "muito frequentemente a minuciosa erudição e a grande pedantaria ocupavam o campo da verdadeira filologia, da crítica

\footnotetext{
${ }^{176}$ Idem. "Queste vengono sempre restituite ai respettivi autori, sia che gli Estensori le annunziino, sia che credano meglio di non doverne parlare."

${ }^{177}$ Pietro Borsieri. "Programma" in II Conciliatore, p I (nossa tradução). "è opera sommamente ardua in sè stessa e non abbastanza pregiata, perché possa lusingar i buoni scrittori ad assumere la fatica." ${ }^{178}$ Idem, ibidem. "(...) confondendo le loro opinioni colla ragione delle cose, la satira collo spirito, e la viltà dell'adulazione colla sincerità della lode (...)." Isso aponta também para preocupações com a qualidade literária, conforme veremos adiante.
} 
filosófica e da pura e elegante literatura." ${ }^{179}$ Mas as dificuldades vividas pela Itália nas décadas posteriores à Revolução Francesa, no entender do autor, ensinaram, de forma dolorosa, os homens a pensar: "Aquela falta de preocupação, que originouse entre nós do longo sono da paz e da pouca comunicação entre as várias partes da Itália, desapareceu por obra de causas adversas." 180 Porém, no momento em que os italianos de diversos quadrantes demandam informação e conhecimento, na opinião do redator do "Programma", a pedantaria acadêmica afasta das discussões sérias o público leigo: “(..) as disputas meramente gramaticais (...) aborrecem (...) grande número de pessoas que não se dedicam aos estudos, mas que buscam na cultura da mente uma urbanidade, uma flor de elegância verdadeiramente digna do Homem." 181 Justamente por isso é preciso difundir na Itália as novas ideias estrangeiras para que essas possam renovar o pensamento italiano. Tendo em vista que, no entender do autor, "a utilidade geral deve ser, sem dúvida, o primeiro objetivo de qualquer um que deseje à sua maneira dedicar seus pensamentos ao serviço do Público." 182 os redatores de II Conciliatore deliberaram que as duas coisas mais úteis para a Itália, e em particular para a Lombardia, eram a Agricultura e o Comércio. O estágio de desenvolvimento agrícola então alcançado, para o grupo de II Conciliatore, exigia que se falasse "dos bons métodos de agricultura, das invenções de novas máquinas, das divisões do trabalho." 183 Já o Comércio necessitava de informações sobre novos métodos produtivos e novos mercados potenciais, pois "não basta dar a conhecer universalmente os bons princípios da ciência econômica para facilitar sua aplicação." 184 Porém, não é intenção dos redatores fazer um jornal de leitura árida e por isso "falaremos de versos, falaremos de prosas, de obras estrangeiras, de obras nacionais, de espetáculos, de declamações, de belas artes, de antigos e de modernos, de poéticas e de preceitos."

\footnotetext{
179 Idem, ibidem. "Più spesso la minuziosa erudizione e la grande pedanteria occupavano il campo della vera filologia, della critica filosofica, della schietta ed elegante letteratura."

${ }^{180}$ Idem, ibidem. "Quella non curanza, che era nata fra noi dal lungo sonno della pace e dalla poca communicazione delle varie genti d'Italia, è ora sparita per opera delle contrarie cagioni."

${ }^{181}$ Idem, ibidem. "(...) le dispute meramente grammaticali (...) annojano (...) gran numero di persone che non professano gli studi, ma che cercano però nella coltura dell'animo una urbanità, un fiore di eleganza veramente degno dell'uomo."

${ }^{182}$ Idem, Ibidem. "L'utilità generale debb'essere senza dubbio il primo scopo di chiunque vuole in qualsiasi modo dedicare i suoi pensieri al servizio del Pubblico; (...)"

${ }^{183}$ Pietro Borsieri. "Programma" in II Conciliatore, p. II (nossa tradução) "(...) dei buoni metodi di agricoltura, delle invenzioni di nuove macchine, della divisione del lavoro (...)."

${ }^{184}$ Idem, ibidem. “(...) non basta far conoscere universalmente i buoni principi della scienza economica per agevolarne l'applicazione."
} 
185

ou seja, de tudo aquilo que seja digno da atenção dos leitores no mundo das artes e das letras. Nesse ponto Borsieri afirma a importância fundamental da Crítica, e não se excusa de fazer uma definição clara do que ela significa: "Nós entendemos por verdadeira Crítica aquela que do íntimo conhecimento do coração humano e das nossas faculdades intelectuais infere as leis e o método com os quais procede, seja na composição das várias obras do intelecto, seja em seu juízo." 186 Não esperem, no entanto, achar nas páginas de II Conciliatore opiniões destrutivas, rígidos preceitos ou entusiásticas louvações ao gênio, pois melhor do que a seriedade dos acadêmicos é o humor livre e malicioso dos literatos libertos das amarras impostas pelas academias decadentes, e todos em nosso jornal fazem parte "deste belo mundo, o qual ama tanto divertir-se, e não sem razão." ${ }^{187} \mathrm{E}$ qual seria, por fim, a intenção de II Conciliatore? Cerrar fileiras na "guerra contra a Grosseria e o Vício para reprimi-los, se possível fosse, somente com as armas da razão do consórcio civil." 188

É possível inferir na leitura do "Programma" que a intenção do grupo de intelectuais que se reuniu em torno de II Conciliatore era das mais ambiciosas. Partindo de uma leitura crítica da situação política e cultural da Itália, muito influenciada pelas ideias românticas importadas da Alemanha, eles pretendiam inserir um novo paradigma na cultura italiana. Em um período de profunda crise de identidade, qual seja, a Restauração imposta pelo Congresso de Viena, em 1815, após a dissolução do Império Napoleônico, a saída encontrada por aqueles que não mais desejavam o domínio estrangeiro só poderia ser a luta pela reunificação territorial e política da Península. Segundo Aldo Vallone, “Il Conciliatore põe-se no centro dos interesses românticos e torna-se o porta-voz daquelas animadas polêmicas.". Acrescentaríamos que o Romantismo defendia uma cultura de matriz local, que se opunha a uma concepção generalizante, mais do agrado do Império Austríaco. Seria razoável supor que não interessava ao Império o surgimento de sentimentos nacionais, muito menos de uma cultura em língua italiana que

\footnotetext{
${ }^{185}$ Idem, ibidem. "Parleremo di versi, parleremo di prose, di opere forestiere, di opere nazionali, di spettacoli, di declamazione, di belle arti, di antichi e di moderni, di poetiche e di precetti (...)."

${ }^{186}$ Idem, ibidem. "Noi intendiamo per vera Critica quella che dall'intima conoscenza dell'umano cuore e dalle nostre varie facoltà intellettuali desume le leggi ed il metodo con che procedere, sia nel comporre le varie opere d'ingegno, sia nel giudicarle."

${ }^{187} \mathrm{Idem}$, ibidem. "(...) di questo bel mondo, il quale ama tanto di ridere e non senza ragione."

${ }^{188}$ Idem, ibidem. "(...) guerra contro la rozzezza e il vizio per isbandirli, se fosse possibile, colle sole armi della ragione dal consorzio civile."
} 
valorizasse a história e as tradições peninsulares. De acordo com Vallone, "jamais um periódico, surgido na Itália, se apresentou em tão variadas seções mais concorde e unitário" do que II Conciliatore. ${ }^{189}$ E como se originou essa "unidade de entendimentos" apontada pelo crítico? Em nossa hipótese de interpretação ela surgiu da origem comum dos envolvidos no projeto: todos eles eram filo-jacobinos ex-partícipes da administração do Reino da Itália, que perderam influência com a Restauração e se convenceram que apenas a independência italiana poderia servir aos seus interesses. Para essas pessoas, assim como para os grupos que elas representavam, não havia sentido em uma cultura classicizante, e por isso não era mais possível aceitar a doutrinação estética imposta pelas academias. É como se pudéssemos entender I/ Conciliatore um arauto, a proclamar a impossibilidade da restauração austríaca e a urgência de uma renovação nas artes e nas letras italianas.

O grande obstáculo a ser transposto por II Conciliatore, ou talvez pudéssemos dizer o fator mais tenso na vida cotidiana do jornal, era a sua relação com a Censura. Todos os colaboradores do periódico, devido ao seu passado filojacobino, estavam cientes de que não seria essa convivência de forma alguma agradável. Um mês após o lançamento do jornal, Ugo Foscolo enviava de Londres uma carta a Silvio Pellico (outubro de 1818) com a pergunta fatal: "Como conciliarão vocês II Conciliatore e seus próprios intelectos e vontades (...) com a Censura?” 190 À guisa de esclarecimento poderíamos responder que não foi possível essa conciliação, mesmo porque as autoridades austríacas não nutriam qualquer ilusão sobre o caráter oposicionista da publicação. Tanto isso é verdade que para nada que desagradasse o governo fosse publicado por descuido ou desídia de algum funcionário negligente, o próprio Conde de Strasoldo, a mais alta autoridade governativa do Reino, exercia a função de censor do jornal.

Existe uma carta de Ludovico di Breme a Federico Confalonieri, datada de 15 de novembro de 1818, ou seja, dois meses após o lançamento de II Conciliatore,

\footnotetext{
${ }^{189}$ Aldo Vallone. . Dal "Caffè" al "Conciliatore", storia delle idee, p. 85 (nossa tradução).

${ }^{190}$ Apud Cesare Cantù. Op cit, p. 283 (nossa tradução). "Come concilierete voi II Conciliatore e l'ingegno e l'animo vostro (...) con la Censura?"
} 
na qual está escrito: "O Senhor de Strasoldo, já de algum tempo ele próprio censor da nossa folha, maneja a foice sem consideração alguma ao bom senso e à boa cortesia." Di Breme reclama que os artigos censurados são enviados à redação "poucas horas antes" do jornal ser distribuído, o que faz com que as lacunas tenham que ser restauradas. Às vezes é necessário "substituir artigos inteiros" e mandá-los de volta à censura. Como decorrência o jornal não chega aos leitores às quintasfeiras e aos domingos, ao meio-dia, como prometido, porém muitas vezes, de acordo com Di Breme, "às sextas e às segundas, e hoje foi propriamente o caso." Outra reclamação é que alguns de seus artigos foram cortados pela metade ("falcidiati per metà") e sua reação foi mostrar a mutilação ao público através de linhas pontilhadas, mas que agora "foi feita uma proibição de pontilhar os espaços." 191

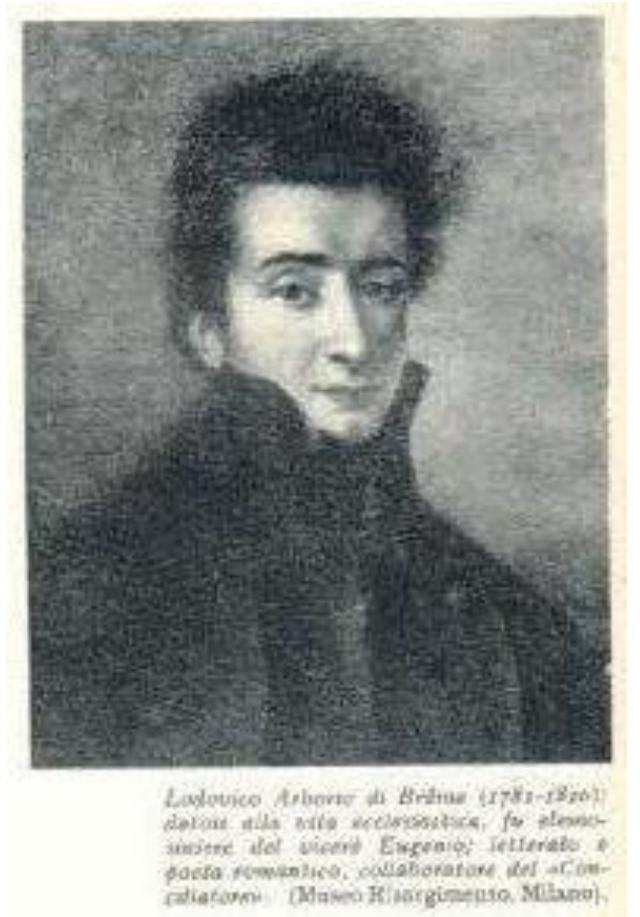

Ludovico Arborio di Breme (1781-1820). Voltado para a vida eclesiástica foi esmoler do vice-rei Eugênio. Literato e poeta romântico, foi colaborador de Il Conciliatore (in Cesare Spellanzon.

Storia del Risorgimento e dell'unità d'Italia, p 772)

\footnotetext{
${ }^{191}$ Apud Cesare Cantù, Op cit, p. 58 (nossa tradução). "(...) II Signor Strasoldo, censore egli stesso del nostro foglio da qualche tempo in qua, mena la falce senza riguardo nè al buon senso nè alla buona creanza. Ne vengono rimandati gli articoli poche ore prima di dover distribuire il foglio; conviene supplire alle lacune, talvolta sostituire interi articoli, sottoporli di nuovo alla censura, e così vien fatto che il foglio non può uscire talvolta che al lunedì e al venerdì, e oggi appunto fu il caso. (...) alcuni miei articoli furono falcidiati per metà; io designai le castrazioni al pubblico disdegno con intere linee di punti; venne fatta proibizione di punteggiare gli spazi."
} 
A contrapartida a essa situação era o reconhecimento, pelo público, de II Conciliatore como um porta-voz da resistência italiana à ocupação austríaca. Em uma carta, sem data, de Silvio Pellico a Luigi Porro Lambertenghi é dito "II Conciliatore, malgrado os incômodos que nos causa, nos dá também satisfações. Todos os dias vemos crescer o número de pessoas que nos fazem justiça." E isso acontecia não apenas na Lombardia. Pellico conta "ontem eu me encontrei com um piemontês que me disse que II Conciliatore, na sua região, modificou a boa opinião que se tinha acerca do liberalismo austríaco." De outro trecho da missiva de Pellico podemos entender que o Romantismo assumia na Itália um caráter de movimento político que ele não possuía, ao menos nesse nível, na Inglaterra e na Alemanha: "Em Turim, assim como em nossas cidades, para se nomear um liberal chamam-no romântico, não se faz nenhuma diferença. E clássico tornou-se sinônimo de ultra, de espião, de inquisidor." 192 Giuseppe Nicolini reforça a impressão deixada por Silvio Pellico em uma carta, sem data, a Camillo Ugoni: "Il Conciliatore não deve mais considerar-se como simplesmente romântico, mas nacional. É uma chama sagrada ("sacra favilla") que surge entre a noite e o gelo da nossa pátria, e não deve absolutamente morrer." 193 É possível inferir dessas cartas um clima de agitação patriótica que levaria ao levante liberal de 1821, que contou com a participação ativa de vários colaboradores de nosso periódico. De acordo com Cesare Cantù, "esses acentos de emoção, vindos de jovens, animados por aquela brisa de liberdade que então percorria a Europa e chegava também à Itália" aumentaram a confiança e a fé daqueles que buscavam uma mudança no quadro político italiano, levando à criação de "teorias sociais mais humanas e elevadas sem que a Opressão intimidasse a Vontade." ${ }^{194}$ Nossa hipótese de interpretação é que /l Conciliatore, introdutor das ideias românticas na Itália, ao assumir uma posição política de oposição ao Império Austríaco e de favorecimento à unificação da Península, deu ao movimento romântico italiano uma configuração diferente daquela usualmente identificada com

\footnotetext{
${ }^{192}$ Apud Cesare Cantù. Op cit, p. 86 (nossa tradução). "Il Conciliatore, malgrado le noie che ci costa, ci dà anche delle compiacenze. Ogni giorno vediamo crescere il numero delle persone che ci rendono giustizia. (...) ieri ho veduto un Piemontese, che $\mathrm{mi}$ ha detto che II Conciliatore ha disingannato il paese circa la buona opinione che s'aveva del liberalismo austríaco. A Torino, come nelle nostre città, per dire un liberale si dice romantico: non si fa più differenza alcuna. E classico è divenuto sinonimo d'ultra, di spia, di inquisitore."

${ }^{193}$ Apud Cesare Cantù. Op cit, p. 243 (nossa tradução). "Il Conciliatore non dee più considerarsi come simplecemente romantico, ma nazionale. È una sacra favilla che sorge tra la notte e il gelo della nostra patria, e non deve assolutamente morire."

${ }^{194}$ Cesare Cantù. Op cit, pp. 87-88 (nossa tradução).
} 
o Romantismo. Essa nova escola estética, para os italianos, não significava apenas uma renovação artística, mas apontava para a urgência de mudanças sócio-políticas que dariam, aí sim, uma nova feição à decadente cultura acadêmica italiana.

Cesare Cantù foi um ativo participante do movimento romântico italiano e ao longo de seus noventa anos de vida presenciou todas as suas fases. Escrevendo em 1878, ele disse que o Romantismo "era uma ampliação da Inteligência, uma batalha contra o convencionalismo literário, um sentimento mais verdadeiro da Natureza." Seria razoável supor que os românticos exerciam uma crítica radical aos paradigmas culturais então vigentes, que se traduzia, nas palavras de Cantù, em uma recusa às "trivialidades acadêmicas, às descrições por epítetos, às declamações frias, às dedicatórias a personagens não meritórias, às invocações a divindades nas quais não se acreditava." Segundo ele, à exaltação promovida pelos classicistas os românticos preferiam "o melancólico sentimento da dor mundial." 195 Podemos inferir que tal atitude não era, em absoluto, incoerente com a situação vivida pelos filo-jacobinos de I/ Conciliatore, beneficiários do regime napoleônico transformados em dissidentes tolerados, sob vigilância, pelas autoridades do Império Austríaco. De acordo com Pier Angelo Menzio, "Il Conciliatore era romântico em Literatura, liberal em Política, e fautor de todo melhoramento, de qualquer reforma no campo moral e social." Para o autor, a repulsa àquilo que é velho, o incômodo com a estruturas de poder, a volúpia por mudanças (diríamos nós, tão modernos, tão nossos contemporâneos) eram a explicação para "a fobia pelas línguas clássicas, a aversão pelas cansativas pesquisas de arquivo". "196 que faziam parte do ideário romântico professado nas páginas de nosso periódico. Para os novos tempos nos quais desejavam inserir a Itália, os românticos compreenderam que tornava-se necessário "o estudo do Homem, seja em nível individual, seja em nível social; da Psicologia e da História: já que não se podia afrontar diretamente as questões políticas, se desejava agitar as literárias", nos esclarece Cesare Cantù. E qual caminho seria possível para II Conciliatore, como deveriam seus colaboradores portar-se diante da censura austríaca? Segundo Cantù, Ihes restava

\footnotetext{
${ }^{195}$ Idem, pp. 27-28 (nossa tradução).

${ }^{196}$ Pier Angelo Menzio (org). Dal Conciliatore, pp. 13 e 14 (nossa tradução).
} 
"elogiar as inovações; exercer uma crítica sutil sobre as novas produções artísticas, nacionais e estrangeiras; tentar a originalidade inferida do conhecimento da História, dos costumes, do Sentimento e da Natureza." ${ }^{197}$ Isso explica a razão pela qual, na opinião de G. A. Borgese, "a harmonia da obra com os tempos que a geraram era, em resumo, a preocupação contínua dos homens de Il Conciliatore." 198 É como se pudéssemos entender que o estudo do Passado permitia aos românticos a construção de uma identidade que distinguia a Península no mapa do Império Austríaco. A exaltação dos costumes e tradições locais, tão ao gosto do Romantismo, criava um sentimento de pertença que fortalecia as ideias independentistas que então floresciam em solo italiano.

Dos vários documentos reunidos por Cesare Cantù em seu livro II Conciliatore e $\boldsymbol{i}$ Carbonari um dos mais interessantes para o nosso estudo é o depoimento de Silvio Pellico à polícia austríaca quando de sua prisão em 1821. Nele podemos ler

\begin{abstract}
Luigi Porro Lambertenghi vivia apenas para a Política, e seu pensamento era todo ocupado pelo vivíssimo desejo de ver toda a Itália elevada ao nível de nação. O pobre Ludovido Di Breme, eu e Giuseppe Pecchio éramos entre os amigos de Porro os mais exaltados por esse sistema. Todos os outros eram liberais, mas não animados pelo mesmo entusiasmo. (...) em resumo, todos mostravam uma propensão às opiniões liberais; porém, nem todos exprimiam o desejo e a esperança de uma mudança de governo, ao contrário, eram tímidos e prudentes. $\mathrm{Na}$ verdade, só participavam do segredo Di Breme, Pecchio e eu. Dessa sociedade foi imaginado um jornal literário que espalhasse com arte princípios de Patriotismo. Foi intitulado II Conciliatore, e circulou de 1818 a 1819, lutando continuamente com a censura, que modificava quase todos os artigos. ${ }^{199}$
\end{abstract}

Seria razoável supor que nesse depoimento à polícia Pellico procurou jogar toda a iniciativa da empreitada do jornal em Di Breme (falecido um ano antes, em 1820), Porro Lambertenghi (então exilado na Inglaterra) e Pecchio (na ocasião também exilado), além de si mesmo (já encarcerado) e livrar de qualquer responsabilidade incriminatória Berchet, Visconti, Borsieri e Romagnosi, que seriam

\footnotetext{
${ }^{197}$ Cesare Cantù. Op cit, p. 34 (nossa tradução).

${ }^{198}$ G. A. Borgese. Storia della critica romantica in Italia, p.135 (nossa tradução).

${ }^{199}$ Apud Cesare Cantù. Op cit, p. 93 (nossa tradução). "Luigi Porro Lambertenghi non viveva che nella politica, e la sua anima era tutta compresa del desiderio vivissimo di vedere l'Italia tutta elevata al rango di nazione. II povero Ludovido di Breme, io di consenso, e Giuseppe Pecchio eravamo fra gli amici di Porro i più caldi per questo sistema. Tutti gli altri erano liberali, ma non animati dallo stesso entusiasmo. (...) tutti in sostanza mostravano di propendere alle openioni liberali; non tutti però esprimevano il desiderio e la speranza di un mutamento di Governo; anzi erano timidi e guardinghi, non essendo veramente nel segreto che il Di Breme, Pecchio e me. Da questa società era stato immaginato un giornale letterario, il quale spargesse con arte principi di patriotismo, e fu intitolato II Conciliatore, e uscì dal 1818 al 1819, combattendo continuamente colla Censura, la quale mutava quasi ogni articolo."
} 
os "tímidos e prudentes". Ele não negou o caráter político do jornal, que deveria difundir "com arte princípios de Patriotismo". E também reconheceu que a censura "modificava quase todos os artigos". O que podemos inferir é que II Conciliatore, projeto destinado a introduzir as ideias românticas na Itália, foi muito limitado em seus propósitos pela atividade censória da administração austríaca do Reino Lombardo-Vêneto, que impossibilitou uma abordagem mais aprofundada dos temas tratados em seus artigos. Em nosso entendimento, quando se leva em conta o ambiente político-institucional no qual o jornal estava inserido fica muito difícil cobrar de seus colaboradores uma postura mais clara e inequívoca em relação aos princípios que eles defendiam. Ao historiador intelectual não cabe julgar, mas compreender o ambiente no qual as ideias foram geradas.

No dia 17 de outubro de 1819 o centésimo décimo oitavo, e último número de II Conciliatore ganhou as ruas milanesas. Cansados de lutar contra a Censura, sob severa crítica dos classicistas e após a ameaça de prisão sofrida por seu editor, Silvio Pellico, $\boldsymbol{i}$ conciliatori depuseram suas armas. Fora uma luta inútil? Teriam razão aqueles que diziam ser o Romantismo uma afronta à tradição cultural da Itália, herdeira da arte e do saber da Antiguidade clássica? Ou teria sido o jornal um arauto pioneiro de ideias que se manifestariam com força muito maior nas décadas seguintes? É claro que hoje essas perguntas são retóricas, mas elas não estavam desprovidas de sentido em 1819. Para termos uma ideia do legado de II Conciliatore selecionamos alguns trechos de três cartas escritas por seus excolaboradores entre 1820 e 1825, curiosamente enviadas ao mesmo destinatário: Camillo Ugoni (1784-1855), de Brescia, literato filo-jacobino que também se envolveu no levante de 1821 e viveu alguns anos no exílio. As cartas foram recolhidas por Cesare Cantù e publicadas em 1878 em seu livro I/ Conciliatore e $\boldsymbol{i}$ Carbonari.

Sete meses após o fechamento de nosso periódico, em 19 de maio de 1820, Luigi Porro Lambertenghi, seu principal financiador, escreveu a Ugoni: "o senhor Goethe, celebridade tedesca, publicou em um jornal da Alemanha um belíssimo artigo sobre a literatura da Itália. Foram bem tratados II Conciliatore e muitos de 
seus colaboradores, mas até agora não pudemos ler o artigo." $200 \mathrm{Na}$ verdade, Goethe escrevera Clássicos e românticos lutam acirradamente na Itália em 1818, dois anos antes da carta de Porro. Esse artigo seria traduzido para o italiano somente sete anos depois, quando foi publicado na revista Antologia, em dezembro de 1825. Nele o grande romântico comenta o embate de ideias, muito pouco cordial, travado em solo peninsular. Ele reconhece que o Romantismo sofre uma grande rejeição da parte dos classicistas.

Porém desejamos observar aquilo que estão empreendendo agora em Milão alguns espíritos mais cultos e gentis, que com modos próprios e honestos procuram reconciliar os diversos partidos e conduzi-los ao lugar onde possam entender-se. Eles anunciaram um jornal, que deverá chamarse II Conciliatore, mas seu programa já foi recebido com graves injúrias, enquanto o público, como de costume, ri dos dois partidos, e assim acaba por destruir qualquer interesse verdadeiro. ${ }^{201}$

É possível inferir que o olhar atento de Goethe já entrevia os problemas futuros de II Conciliatore. Não seria nada fácil conciliar posições ideológicas conflitantes, num ambiente de antagonismo aberto e ainda enfrentar o desinteresse do público em geral pelas questões debatidas. Quase um ano e meio depois do encerramento do jornal, Pietro Borsieri, em carta datada de 2 de janeiro de 1820, dizia "soube que a Revue Encyclopédique traz em seu último número longo artigo de Sismondi, no qual ele celebra Di Breme e II Conciliatore. Imagine com que alegria eu leria esse número, mas aqui não é permitida a sua distribuição." 2020 periódico ainda era um assunto relevante. Em 1825, escrevendo de Paris a Camillo Ugoni, Giuseppe Nicolini contava que os franceses se achavam então no ponto "em que já estávamos nós na Itália seis ou sete anos atrás." As grandes discussões giravam em torno dos temas que foram tão caros aos românticos milaneses: "guerra às unidades dramáticas, crucificação da Mitologia, nacionalização dos enredos, originalidade das imagens; não era isso que se debatia entre nós sete anos atrás, e

\footnotetext{
${ }^{200}$ Apud Cesare Cantù, Op cit, p. 20 (nossa tradução). "Il signor Goethe, celebre tedesco, ha fatto inserire in um foglio di Germania un belissimo articolo sulla letteratura d'Italia. II Conciliatore vi fu ben trattato e molti scrittori di esso, ma fin ora non abbiamo potuto leggere l'articolo."

${ }^{201}$ Goethe. "Classici e romantici lottano accanitamente in Italia - 1818" (Antologia, dicembre 1825) in Discussioni e Polemiche sul Romanticismo (1816-1826), volume 2, p. 479 (nossa tradução). "Però vogliamo osservare ciò che intraprendono in Milano alcuni spiriti più culti e gentili, che con modi onesti e propri cercano ravvicinare i diversi partiti, e condurli al punto d'onde possamo intendersi. Essi già annunziarono un giornale che dovea dirsi il Conciliatore, ma il programma è già stato ricevuto con disdegnoso insulto, mentre il pubblico, secondo il solito, ride dei due partiti, e con ciò distrugge ogni vero interesse."

${ }^{202}$ Apud Cesare Cantù. Op cit, p. 182 (nossa tradução). "Ho saputo che la Revue Encyclopédique porta nell'ultimo numero um lungo articolo di Sismondi, in commemorazione di Di Breme e del Conciliatore. Puoi immaginarti se leggerei volentieri questo numero: ma qui non è permessa la distribuzione."
} 
que continua ainda a debater-se em Paris?" 203 É como se pudéssemos entender que a onda romântica se propagava, invadindo novas terras, destruindo antigas certezas e trazendo à ribalta da cena cultural europeia novos e marcantes personagens.

Pier Angelo Menzio recorda que meses antes que II Conciliatore deixasse de ser publicado, Vieusseux tinha aberto em Florença (em julho de 1819) "um Gabinete de Leitura, do qual surgiu a Antologia." Essa revista, que tinha a proposta de superar as discussões entre classicistas e românticos, "chamou a colaborar os italianos sinceros de todas as escolas e partidos" e circulou até 1833, quando também foi fechada por imposição do governo austríaco. Mas então apareceu o Archivio storico italiano. Segundo Menzio "as sementes plantadas por II Conciliatore, pela Antologia e pelo Archivio storico italiano, assim como por outros livros e publicações germinaram e delas cresceram plantas vigorosas." 204

$\mathrm{Na}$ Itália, o Romantismo veio ao encontro das aspirações libertárias e independentistas da geração nascida na década de 1780 em diante. Isso porque ele serviu como um aglutinador de ideias e sentimentos nacionais que vinham sendo gestados desde meados do século XVIII ${ }^{205}$. A introdução das ideias românticas na Península Itálica deu-se em um momento complexo na política e na cultura italianas: o lustro que vai do encerramento do Congresso de Viena, em 1815, até a eclosão das revoluções liberais a partir de 1820. É no bojo das acaloradas discussões políticas e estéticas iniciadas em 1816 que surgiu o projeto de um jornal literário que servisse de difusor e de comentador de obras que esboçavam um ponto de vista

\footnotetext{
${ }^{203}$ Apud Cesare Cantù. Op cit, pp. 252-253 (nossa tradução). "Del rimanente mi pare che costì siasi ancora a'termini in cui eravamo noi in Italia già sei o sette anni fanno. Vi ricordate voi delle nostre passeggiate letterarie, delle battaglie della capitale, delle nostre ruggini municipali? Guerra alle unità drammatiche, croce alla mitologia, nazionalità di soggetti, originalità d'immagini; non è questo ciò che si dibatteva fra noi sette anni fa, e che si seguitta a dibattere ancora a Parigi?"

${ }^{204}$ Pier Angelo Menzio (org). Dal Conciliatore, p. 36 (nossa tradução). Giovan Pietro Vieusseux (Oneglia, 1799 - Florença, 1863), romântico e patriota italiano fundou o Gabinete de Leitura para difundir na Itália obras românticas nacionais e estrangeiras. O Gabinete de Leitura era um clube de leitores nos moldes dos clubes de tal gênero que haviam surgido na Inglaterra na década de 1780 . (ver E. J. Clery. The Rise of Supernatural Fiction).

${ }^{205}$ Para uma visão mais elaborada desse processo ver Aldo Vallone. Dal "Caffè" al "Conciliatore", storia delle idee (Lucca, 1953).
} 
diverso daqueles então predominantes entre os grupos hegemônicos da intelectualidade nativa.

Quando analisamos as biografias do grupo de intelectuais que fundou e colaborou em II Conciliatore percebemos que eles se encaixam no perfil dos "FiloJacobinos", como nomeou o historiador britânico Eric J. Hobsbawn os italianos que serviram as administrações francesas instaladas durante as ocupações napoleônicas nos primeiros lustros do século XIX ${ }^{206}$. Todos eles, alguns mais outros menos, haviam sido funcionários ou militares a serviço do Vice-Rei da Itália, Eugênio Beauharnais, deposto após a queda de seu tio Napoleão Bonaparte. Isso pode explicar a severa censura a que nosso jornal foi submetido por parte do governo austríaco. II Conciliatore bateu-se por um novo paradigma na cultura italiana: a valorização da língua do povo contra o Latim, usado pelos acadêmicos; a negação da herança greco-romana em favor do legado cultural dos povos que ocuparam a Península na Idade Média; a preferência pelos enredos históricos ao invés dos enredos de inspiração mitológica; e a defesa de uma historiografia voltada para a formação das nações em oposição à exaltação dos grandes vultos do Passado.

A mão pesada do governo austríaco do Reino Lombardo-Vêneto, cuja censura a II Conciliatore era função exercida pela mais alta autoridade presente, Conde de Strasoldo, se por um lado criou inúmeras dificuldades na vida cotidiana de seus redatores e colaboradores, por outro mostrou ao público italiano o compromisso do jornal com a independência do país. Ao associar Romantismo com Liberalismo e Classicismo com Absolutismo, ou seja, com o Antigo Regime, os fautores italianos da nova escola deram-lhe uma faceta política muito mais pronunciada do que aquela dos movimentos românticos na Inglaterra e na Alemanha. Desenvolveu-se a ideia de que a decadência da cultura italiana estava ligada à situação institucional do país e que sua renovação passava obrigatoriamente por uma mudança política estrutural. O fim abrupto e melancólico de II Conciliatore, em outubro de 1819, não modificou esse quadro.

Nós entendemos que o principal desafio de um historiador intelectual é reproduzir o ambiente histórico no qual as ideias que ele estuda foram geradas. Estudar obras fora de seu contexto original torna muito difícil entender sua repercussão. Por outro lado, compreendemos ser essa uma tarefa complexa porque

${ }^{206}$ Eric J. Hobsbawn. A Era das Revoluções, pp. 95-116. 
temos frequentemente que lidar com a imagem que uma determinada época histórica criou de si mesma. Não raro a visão dos pósteros não é a mesma dos coevos. Não cabe a nós julgar o Passado, nosso intento é analisar os paradigmas culturais que estruturaram um determinado período histórico, usando para isso os instrumentos oferecidos por nossos próprios tempos.

\subsection{A reação}

No dia 25 de maio de 1903 finalizou-se a edição, na tipografia Nistri, em Pisa, do livro II Conciliatore, periodico milanese (1818-1819), de Edmondo Clerice ${ }^{207}$. Lançado exatos vinte e cinco anos após o aparecimento de II Conciliatore e $\boldsymbol{i}$ Carbonari, de Cesare Cantù, publicado originalmente em 1878, o novo trabalho sobre o jornal romântico milanês mostrou-se bastante crítico ao seu predecessor. Clerice reconhece "com relação ao periódico milanês II Conciliatore não existe senão uma obra específica, aquela de Cantù, precisamente intitulada II Conciliatore

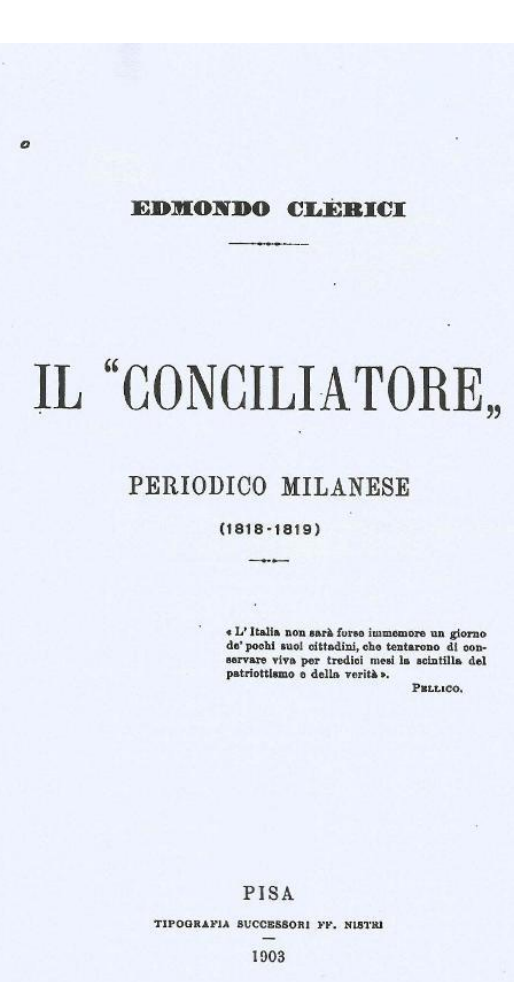
e i Carbonari." Mas o autor considera tal obra "muito confusa" e, na sua opinião, as informações ali contidas, embora numerosas e variadas, não se relacionam entre si, “as várias partes do livro são desenvolvidas desordenadamente e de uma maneira assaz incompleta." Outro ponto levantado por Clerice é que o próprio Cantù, no prólogo de sua obra diz "não se ocupar tanto do periódico, quanto das pessoas particulares que ali colaboraram." $208 \mathrm{Na}$ verdade, Cantù começa seu livro constatando que uma "nova geração, com novos pensamentos" sucede à sua e que no declínio da vida "se ama mais aquilo que pereceu ou está

\footnotetext{
${ }^{207}$ Exemplar digitalizado disponível na biblioteca da Universidade de Harvard. O original foi doado àquela instituição em 1931.

${ }^{208}$ Edmondo Clerice. II Conciliatore, periodico milanese, p. IX (nossa tradução).
} 
perto de perecer" e que portanto existe a necessidade de rememorar tempos dos quais "já são poucos os sobreviventes." 209 Podemos inferir que a principal preocupação de Cesare Cantù é com a Memória, ou seja, resgatar através de suas cartas a visão daqueles personagens tão determinantes para a reconstrução de um período histórico que então, em 1878, já completara cinquenta anos: a restauração do domínio austríaco no norte da Itália nos desdobramentos do Congresso de Viena, após a derrota definitiva de Napoleão Bonaparte em 1814. Edmondo Clerice se propõe a fazer "não um trabalho histórico, mas um trabalho de história literária", ${ }^{210}$ e para isso ele recorreu a uma bibliografia majoritariamente escrita e publicada após 1860, ou seja, pela geração que sucedeu a de Cesare Cantù. O livro de Clerice está dividido em nove capítulos e uma conclusão, todos eles abastecidos com numerosas notas de rodapé e várias citações bibliográficas frutos de uma robusta pesquisa acadêmica.

Muito embora o primeiro número de II Conciliatore tenha sido publicado no dia 3 de setembro de 1818, a ideia de lançar um jornal que difundisse na Itália as concepções estéticas que já vinham sendo divulgadas na Alemanha havia duas décadas $^{211}$ surgiu em 1816. Em uma carta datada de 3 de abril daquele ano, Silvio Pellico contou a seu irmão Luigi

O público de Milão comenta e os oráculos predizem que um outro jornal
nascerá (...). Ele está sendo finalizado em enorme segredo dentro de três
cérebros que se reúnem todas as noites para preparar tudo o que é
necessário para a felicidade do parto. O nome de batismo será: II
Bersagliere, giornale drammatico-morale. Quatro personagens fictícios
redigirão essa folha: um pedante, um cínico, um sentimental e um homem
de bom senso. O objetivo principal será a difusão das luzes, pelo menos em
teorias literárias. (...) Os três cérebros grávidos são Breme, Borsieri e
Pellico. Teremos por fautores a Staël, Schlegel, Sismondi e Gingené. ${ }^{212}$

Seria razoável supor que do atirador (bersagliere) ao conciliador (conciliatore) o caminho não tenha sido fácil. Em outra parte deste estudo ${ }^{213}$ analisamos a carreira dos colaboradores de nosso jornal, assim como os problemas

\footnotetext{
${ }^{209}$ Cesare Cantù. II Conciliatore e i Carbonari, p. 2 (nossa tradução).

${ }^{210}$ Edmondo Clerice. Op cit, p. IX (nossa tradução).

211 Conforme já apontamos o primeiro órgão de promoção das ideias românticas na Alemanha foi a revista Athenaeum, dirigida pelos irmãos Friedrich e August-Wilhelm Schlegel, lançada em 1798.

${ }^{212}$ Apud Edmondo Clerice. Op cit, p. 6 (nossa tradução). "Il pubblico di Milano sbadiglia e gli oracoli predicano che un altro giornale nascerà. (...) Esso si sta compiendo in gran segreto, in tre cervelli che si radunano ogni sera per preparare tutto ciò che occorre alla felicità del parto. II nome di battesimo sarà questo: II Bersagliere, giornale drammatico-morale: quattro finti personaggi compileranno questo foglio, un pedante, un cinico, un sentimentale, um uomo di buon senso: lo scopo principale sarà la diffusione dei lumi, almeno in teorie letterarie. (...) I tre cervelli gravidi sono Breme, Borsieri e Pellico. Avremo per fautori nell'estero la Staël, Schlegel, Sismondi, Gingené."

${ }^{213}$ Ver em 3.1 A Renovação.
} 
que este enfrentou devido à severa censura do governo austríaco. De acordo com Edmondo Clerice, "as circunstâncias que concorreram para o surgimento de II Conciliatore deram ao seu aparecimento um significado político, que o distingue de todos os outros periódicos anteriores ou coevos." 214 Defensora e propagadora do Liberalismo e do Romantismo, a Folha Azul sofreu desde o começo ataques daqueles que se beneficiavam do estado de coisas no Reino Lombardo-Vêneto durante o período da Restauração. Por isso, segundo Clerice, "para melhor propagar seus objetivos II Conciliatore serviu-se frequentemente de brincadeiras irônicas e daquelas alegorias tão largamente adotadas no século anterior". ${ }^{215}$ É possível inferir que as manifestações contrárias aos românticos milaneses não ficaram restritas ao âmbito literário. Clerice registra que se no princípio surgiram várias maledicências sobre o jornal e seus colaboradores, passou-se depois aos ataques "em outros periódicos e libelos, caricaturas nas folhas, palavras ofensivas (motti villani) nos muros." Com o prosseguimento impávido de suas atividades os colaboradores do jornal começaram a receber "insultos nas ruas; Berchet e Pellico foram maltratados pela gentalha (plebaglia), viram alguns números de seu periódico rasgados: por último vieram a campo os meganhas (i birri) e os inquisidores." 216 Silvio Pellico, diretor do jornal, não se abalava diante de tais circunstâncias, pois acreditava sinceramente que seus inimigos "pertenciam à classe mais desacreditada" da sociedade italiana de então e que todos os italianos que realmente desejavam um futuro melhor para a Itália não podiam discordar das ideias de II Conciliatore. ${ }^{217}$

Para que possamos entender melhor o ambiente cultural que gerou II Conciliatore é preciso analisar o impacto que tiveram na Itália duas obras fundamentais para a difusão das ideias românticas: De la Allemagne, de Madame de Staël, e o Curso de Literatura Dramática, de August Wilhelm Schlegel. Edmondo Clerice nota que a obra de Madame de Staël "traduzida para o italiano em 1814 e o Curso de Literatura Dramática de Schlegel, traduzido por Giovanni Gerardhini em 1817 são muito frequentemente citados pela Folha Azul, junto com a história da poesia e da eloquência de Bouterweck, traduzida no mesmo ano de

\footnotetext{
${ }^{214}$ Edmondo Clerice. Op cit, p. 37 (nossa tradução).

215 Idem, p 40 (nossa tradução).

216 Idem, p 47 (nossa tradução)

217 Idem, p 49 (nossa tradução)
} 
1817." 218 De acordo com Carlo Calcaterra, a polêmica entre classicistas e românticos teve início quando o artigo De l'esprit des traductions, de Madame de Staël, "traduzido para o italiano por Pietro Giordani com o título Sulla maniera e sulla utilità delle traduzioni, apareceu na Biblioteca italiana de janeiro de 1816." Houve inúmeras contestações à ideia central do artigo: os italianos deveriam traduzir obras de autores estrangeiros se quisessem melhorar a qualidade de sua literatura, pois as convenções estéticas então relevantes não eram produzidas em língua italiana. A reação negativa ao artigo foi de tais proporções que, segundo Calcaterra, "a Biblioteca italiana, no fascículo de abril, tentou jogar água na fervura com um escrito (anônimo, mas certamente de Pietro Giordani, que havia traduzido o artigo De l'esprit des traductions) intitulado Sul discorso di Madama di Staël - Lettera di un italiano ai compilatori della Biblioteca italiana. Madame de Staël replicou no fascículo de junho com uma Lettera ai signori compilatori della Biblioteca italiana." ${ }^{219}$ É como se pudéssemos entender que houve um certo recuo tático dos românticos devido ao poder de fogo dos classicistas, então majoritários.

No fascículo de abril de 1816 da Biblioteca italiana, Giovanni Gherardini, prócere classicista, publicou um artigo com o título Un italiano risponde al discorso della Staël. Ali o autor argumenta que não se opõe a que um italiano "deseje conhecer as poesias e as fantasias dos setentrionais" da mesma forma que possa também visitar, com proveito, os países do norte da Europa. Mas prossegue enfaticamente, "nego que aquelas literaturas (muito embora belas e elogiáveis) possam enriquecer e embelezar a nossa, por que são essencialmente insociáveis." 220 Vai na mesma linha outro escrito de 1816 publicado em Milão, Risposta ai due discorsi di Madama di Staël, onde Carlo Giuseppe Londonio refuta os dois artigos

\footnotetext{
${ }^{218}$ Idem, p. 84 (nossa tradução). Anne Louise Germaine Necker, Madame de Staël (1766-1817); August Wilhelm Schelegel (1767-1845); Friedrick Bouterweck (1765-1828). A obra Geschichte der Poesie und Beredsamkeit, mencionada de passagem por Edmondo Clerice foi resenhada por Grisostomo (Giovanni Berchet) nos números 9 (01/10/1818), 13 (15/10/1818), 21 (12/11/1818) de II Conciliatore. De acordo com Guilhermino César, "Friedrick Bouterweck (1765-1828), erudito alemão, foi o primeiro europeu que estudou autores brasileiros, numa obra coletiva, de ambiciosas proporções, sobre as artes e as ciências, do Renascimento aos fins do século XVIII." (Historiadores e críticos do Romantismo, volume 1, $p$ XV).

${ }^{219}$ Carlo Calcaterra. "Introduzione" in I manifesti romantici del 1816 e gli scritti principali del "Conciliatore" sul Romanticismo, p. 81, nota 2 (nossa tradução).

${ }^{220}$ Giovanni Gherardini. "Un italiano risponde al discorso della Staël" (Biblioteca italiana, aprile 1816) in Discussioni e Polemiche sul Romanticismo (1816-1826), volume 1, pp 22-23 (nossa tradução). "Non dico per questo che non possa ragionevolmente un italiano voler conoscere le poesie e le fantasie de' settentrionali, come può benessimo recarsi personalmente a visitare i lor paesi; ma nego che quelle letterature (comunque verso di se belle e lodevoli) possono arrichire e abbelire la nostra, poiché sono essenzialmente insociabili."
} 
da romântica francesa endereçados à Biblioteca italiana. Londonio diz que mesmo se fosse verdadeira "e não suposta a esterilidade da nossa literatura, não por isso dever-se-ia jamais, na minha opinião, procurar o remédio na tradução e na imitação de obras estrangeiras." Ele desenvolve um raciocínio segundo o qual cada nação possui "um caráter diferente e uma maneira diferente de sentir" que os escritores procuram expressar em suas obras e portanto para que se "enxerte em uma nação a literatura de uma outra" seria necessário imprimir nessa "o mesmo caráter e os mesmos costumes" daquela que se pretende imitar. 221 O mesmo Giovanni Gherardini apesar de ter traduzido em 1817 o Curso de Literatura Dramática de August Wilhelm Schlegel, comenta que William Shakespeare "é poeta grande, sublime, extraordinário", porém ressalta que nem por isso "bizarra não seja a forma dos seus dramas, e que não se achem neles enormes defeitos, que não podem ser tolerados por um povo herdeiro do gosto daqueles mestres imortais, que ensinaram ao Universo as verdadeiras regras de todas as belas artes." 222 À guisa de esclarecimento gostaríamos de lembrar que foi contra essa visão dos italianos como "um povo herdeiro do gosto daqueles mestres imortais" da Antiguidade que se insurgiram os românticos. Para eles "as verdadeiras regras de todas as belas artes" eram uma camisa-de-força que tolhia a cultura italiana, condenada a reproduzir os mesmos argumentos $\mathrm{e}$ as mesmas imagens que se impunham desde 0 Renascimento. Os românticos acreditavam ser necessário, segundo Edmondo Clerice, revigorar "a literatura nacional com o estudo das estrangeiras. Uma das maiores fadigas sustentadas pelo nosso periódico foi justamente aquela de demonstrar aos italianos que estes não podiam mais considerar-se o primeiro povo

${ }^{221}$ Carlo Giuseppe Londonio. "Risposta ai due discorsi di Madama di Staël" (Milano, 1816) in Discussioni e Polemiche sul Romanticismo (1816-1826), volume 1, p. 70 (nossa tradução). "Ma fosse essa pur vera e non supposta la sterelità della nostra letteratura, non perciò dovrebbese mai, a mio avviso, cercarne il rimedio nel tradurre e nell'imitare le opere d'oltremonte. Ogni nazione, in quella guisa che ha un cielo e un clima diverso, ha pure un carattere diverso ed un diverso modo di sentire; e diffati noi vediamo che le produzioni letterarie hanno presso ciascuna di loro un carattere particolare che le distingue, appunto come certi tratti della fisionomia distinguono gli individui dell'una da quei delle altre. Per poter dunque innestare in una nazione la letteratura d'un'altra, bisognerebbe poterle imprimire lo stesso carattere e gli stessi costumi, bisognerebbe cangiare il suo cielo, farle dimenticare il suo clima; (...)"

${ }^{222}$ Giovanni Gherardini. "Due note al 'Corso di letteratura drammatica' di A. W. Schlegel" (1817) in Discussioni e Polemiche sul Romanticismo (1816-1826), volume 1, pp 201-202 (nossa tradução) "Shakespeare, io ridigo, è poeta grande, sublime, straordinario; chiunque lo ha letto e ben meditato, s'egli ha fior di senno, debb'esser capace di tal verità; ma non rimane per che bizarra non sia la forma de' suoi drammi, e che non vi si trovino enormi diffeti, da non poter tollerare da un popolo erede del gusto di quegl'immortali maestri che insegnarono all'universo le vere norme di tutte le belle arti." 
do mundo." ${ }^{223}$ É como se pudéssemos entender o Romantismo, pelo menos nessa vertente manifesta no período pós-napoleônico, como uma tentativa de inserção da cultura italiana em um contexto mais amplo, mais europeu. Os classicistas, com exceção dos mais radicais, reconheciam de forma sincera as fragilidades da produção artística e cultural de sua época, mas, ao contrário dos românticos, não acreditavam que uma renovação surgisse pelo contato com ideias externas.

Um ponto importante destacado por Clerice é que na Itália, assim como na Alemanha e em outros países, "o Romantismo, por natureza um pouco vago e nunca bem determinado, teve vários períodos: o primeiro romantismo lombardo ou de II Conciliatore descende em linha reta daquela renovação literária e filosófica desenvolvida na Alemanha no século XVIII, a que Schlegel designou com o nome genérico de Romantismo." ${ }^{224}$ Essa vinculação entre os românticos da Lombardia e seus congêneres alemães foi comentada por Goethe em um artigo escrito em 1818:

O público se divide em dois partidos que estão colocados em posição de batalha. $E$ enquanto nós tedescos usamos tranquilamente 0 adjetivo romântico quando temos oportunidade, indicam os italianos duas seitas irreconciliáveis com as denominações de Romantismo e de Classicismo. (...) A cidade de Milão é otimamente adaptada para servir de campo a essa luta, porque ali, mais do que em qualquer outro lugar da Itália, encontra-se reunido um bom número de literatos e de artistas, os quais, na falta de discussões políticas procuram com interesse dobrado polêmicas literárias. E tanto mais essa importante cidade deveria ser a primeira a agitar esta disputa por que a sua vizinhança e as suas várias relações com a Alemanha dão-Ihe oportunidade de adquirir uma ideia da língua e da cultura dos tedescos. ${ }^{225}$

É interessante notar como Goethe justifica geograficamente a influência alemã no panorama cultural de Milão, o que explicaria as diferenças entre as posições dos membros do grupo de II Conciliatore e as posturas dos românticos após 1830. Escrevendo em 1920, G. A. Borgese notou que "à romanticomaquia italiana faltaram quase absolutamente claras distinções entre uma e outra das duas partes litigantes. Quem defendia as ideias românticas era frequentemente, sem dar-

\footnotetext{
${ }^{223}$ Edmondo Clerice. Op cit, p. 93 (nossa tradução)

${ }^{224}$ Idem, p. 99 (nossa tradução)

225 Goethe. "Classici e romantici lottano accanitamente in Italia - 1818" (Antologia, 1825) in Discussioni e Polemiche sul Romanticismo (1816-1826), volume 2, p. 476 (nossa tradução). "II pubblico si divide in due partiti che si stanno incontro in ordine di battaglia, e mentre noi tedeschi ci serviamo tranquillamente dell'aggettivo romantico, quando ne abbiamo occasione, indicano gli italiani due sette irreconciliabili con le denominazioni di romantismo e di classicismo. (...) La città di Milano è ottimamente adatta a servir di campo a questa pugna, perché ivi più che in altro luogo d'Italia trovasi riunito buon numero di litterati e di artisti, i quali, in mancanza di discussioni politiche, cercano doppio interesse in letterarie contese. E tanto più doveva questa importante città esser la prima ad agitar questa disputa, in quanto che la sua vicinanza e i suoi vari rapporti con la Germania, le danno occasione di acquistare idea della lingua e della coltura dei tedeschi."
} 
se conta, mais clássico ou mais classicista do que seu adversário." O crítico acredita que concepções autenticamente românticas, ou seja, aquelas baseadas em uma experiência individual que se sobrepõe tanto às convenções sociais quanto ao momento histórico e que portanto desafiam a unidade formal tão ao gosto dos clássicos, apareceram na Itália de maneira esporádica e fugaz. De acordo com Borgese "quem se colocava como classicista ou antirromântico era imbuído até o fundo de ideias que grosso modo poderiam ser chamadas românticas." 226

Um exemplo dessa, digamos, ambiguidade pode ser encontrado em Carlo Giuseppe Londonio, que em 1817 dizia "romântico é aquele argumento que cria em torno da história, da religião e dos costumes dos povos modernos, e certamente não se pode negar que tudo aquilo que se refere às nossas opiniões, aos nosso usos, aos acontecimentos que tiveram ou possam ter uma influência direta sobre a nossa pátria deve nos interessar muito mais do que coisas que se referem aos tempos remotos, e a uma religião que desapareceu do mundo junto com os povos que a professavam." 227 É como se pudéssemos entender que o autor, ao defender o interesse das coisas coevas perfila-se entre os românticos. Ele porém, muito embora reconheça que existem belezas na poesia romântica não acredita que se deva "renunciar a um sistema mais perfeito, mais explicado, mais essencialmente belo, como o clássico." Em sua opinião ainda que a perfeição das obras de gregos e romanos não possa ser alcançada pelos modernos não é desejável "andar à procura de novas formas" abandonando o caminho traçado pelos mestres da Antiguidade, que nos legaram exemplos sublimes de poesia, e deixar-se guiar "pelas incertas e confusas regras dos modernos legisladores de literatura." 228

Outra mudança proposta pelos românticos foi a substituição da Mitologia pela História como paradigma para a nova criação artístico-literária. Em II Conciliatore, o

\footnotetext{
${ }^{226}$ G. A. Borgese. Storia della critica romantica in Italia, p. X - nuova prefazione, 1920 (nossa tradução)

${ }^{227}$ Carlo Giuseppe Londonio. "Cenni critici sulla poesia romantica" (Milano, 1817) in Discussioni e Polemiche sul Romanticismo (1816-1826), volume 1, p. 221 (nossa tradução). "Romantico è quel soggetto che si aggira intorno alla storia, alla religione, ai costumi dei popoli moderni, e certamente non può negarsi che tutto ciò che si riferisce alle nostri opinioni, agli usi nostri, ad avvenimenti che hanno avuto o possano avere una diretta influenza sulla nostra patria, deve interessarci assai più di cose che si riferiscono ai tempi da noi remoti, e ad una religione che è scomparsa dal mondo insieme coi popoli che la professavano."

${ }^{228}$ Idem, p. 229 (nossa tradução). "Abbia pure dunque le sue particolare bellezze anche la poesia romantica, non per questo si dovrà rinunziare ad un sistema più perfetto, più ragionato, più essenzialmente bello, come il classico. E se per comune consenso si riconosce l'inarrivabile perfezione dei capi d'opera lasciatici dai greci in ogni specie di poesia, si cessi una volta di andare in cerca di nuove forme, e non si abbandoni il sicuro esempio di quei primi maestri del mondo, per le incerte e confuse norme dei moderni legislatori di letteratura."
} 
período histórico mais frequentemente evocado, nas palavras de Edmondo Clerice, "é naturalmente o medievo". Mas qual Idade Média? Segundo Clerice, "aquela idade dos pequenos estados (comuni) nos quais surgiam, com todas as suas expressões de energia e de força, as admiráveis virtudes da liga lombarda. Idade gloriosa, para a qual tanto o romantismo literário quanto o patriotismo liberal convergiam." 229 À guisa de esclarecimento diríamos que essa visão sobre a Idade Média expressa por nosso autor é romântica. Um classicista coevo a II Conciliatore como Carlo Giuseppe Londonio tem uma opinião muito diferente:

É belo ler nas antigas crônicas e nos poemas de nossos épicos os magnânimos feitos dos cavaleiros andantes. Mas que barbárie, que anarquia não se presume daquele estado de sociedade no qual a Virtude e a Inocência, mal defendidas pelas leis, eram constrangidas a colocarem-se sob a proteção de um particular? Retornemos àquela época desafortunada e veremos a Europa coberta de terras estéreis, de bosques e de pântanos; as províncias, as cidades e mesmo as famílias, divididas por ódios eternos, dilacerarem-se e destruírem-se sucessivamente; nenhum comércio, nenhuma comunicação entre as nações; as ciências e as artes negligenciadas, a Justiça oprimida pela Violência, a Religião deturpada pela Superstição; soberanos sem força para fazerem-se obedecer pelos próprios vassalos e para proteger o povo contra a prepotência daqueles; os barões sempre em guerra entre si, concordando apenas na oposição à vontade do soberano e ao bem do Estado; o povo miserável, aviltado e valorizado a par das bestas de carga; veremos a Honra, a Vida, as coisas enfim abandonadas à fortuita decisão do duelo assim como da prova do fogo e da água fervente; veremos a Europa inteira armar-se mais e mais vezes para tirar das mãos dos infiéis os lugares consagrados pelas mais veneráveis memórias da nossa religião, e aqueles campeões da Cruz, aqueles modelos de Religiosidade, de Virtude, de Honra deturparem com mil atrocidades o nome cristão e morrerem vítimas da Discórdia, da Deslealdade e da Dissolução. Se assim são, como infelizmente são, aqueles tempos heroicos que os da moderna civilização propõe à nossa admiração, bem podemos felicitar-nos por viver neste século prosaico e em meio a atual depravação.

${ }^{229}$ Edmondo Clerice. Op cit, p. 196 (nossa tradução)

${ }^{230}$ Carlo Giuseppe Londonio. Op cit, pp 232-233 (nossa tradução) "Bello è il leggere nelle antiche cronache e nei poemi dei nostri epici le magnanime imprese dei cavalieri erranti; ma quale barbarie, quale anarchia non suppone necessariamente quello stato di società in cui la virtù e l'innocenza, mal difese dalle leggi, erano costrette a porsi sotto la protezione d'un privato! Rimontiamo a quell'epoca sfortunata, e vedremo l'Europa coperta di lande, di boschi, di paludi; le provincie, le città le famiglie divisi da odi eterni lacerarsi, distruggersi a vicenda; nessun commercio, nessuna communicazione da nazione a nazione; le scienze e le arti neglette, la giustizia conculcata dalla violenza, la religione deturpata dalla superstizione; i sovrani mancanti di forza per farsi ubbidire dai propri vassalli e per proteggere il popolo contro la loro prepotenza; i baroni sempre in guerra fra loro, e concordi solo nell'opporsi alla volontà del sovrano e al bene dello stato; il popolo miserabile, avvilito e valutato quanto le bestie da soma; vedremo l'onore, la vita, le sostanze abbandonate alla fortuita decisione del duello e della prova del fuoco e dell'acqua bolente; vedremo l'Europa intiera armarsi più e più volte per togliere dalle mani degli infideli i luoghi consacrati dalle più venerande memorie dalla nostra religione, e quei campioni della croce, quei modelli di religione, di virtù, d'onore, deturpare con mille scelleraggini il nome cristiano e perir vittime della discordia, della slealtà, della dissolutezza. Se tali sono, come lo sono pur troppo, quei tempi eroici che dalla moderna civilizzazione si propongono alla nostra ammirazione, ben possiamo felicitarci di vivere in questo secolo prosaico e in mezzo all'attuale depravazione." 
Acrescentaríamos que a visão antirromântica tinha também uma base histórica. Segundo Paride Zaiotti, em artigo publicado na Biblioteca italiana em 1819, "os italianos receberam dos latinos a Mitologia como um patrimônio; quando esta deixou de ser a religião dos povos, foi confinada aos versos. Mas, transformada em linguagem poética, não pode ser rejeitada, senão por quem ignora que em fábulas não se acredita como em verdades religiosas, porém elas são consideradas como ídolos da Fantasia e como alegorias sapientíssimas." 231 No entanto, os românticos batiam-se pela exclusão dos temas mitológicos e declaravam pedantes todos os admiradores da Antiguidade. De acordo com Edmondo Clerice, os membros do grupo de II Conciliatore nutriam um verdadeiro "ódio pelas regras aristotélicas do drama, assim como por qualquer outra regra imposta por falsas leis consuetudinárias e não intuída pelo próprio gênio do poeta ou pela natureza do argumento." 232 É como se pudéssemos entender que os românticos propunham total liberdade criativa ao Artista, libertando-o dos paradigmas estritos das academias artísticas e literárias. Tirando da História os argumentos de seu trabalho, a seleção dos fatos assim como a construção dos caracteres dos personagens ficavam ao talante do criador da obra. É contra essa proposta que se insurge o artigo de Pietro Molossi publicado no Accattabrighe, o jornal criado pelo chefe de polícia de Milão para contrapor-se ferozmente a II Conciliatore (é interessante lembrar que as folhas do Accattabrighe eram cor de salmão, em oposição às páginas azuis de II Conciliatore). Molossi argumenta que ao serem muito fiéis às mínimas circunstâncias históricas os românticos (Alemani, como ele os denomina) acreditam que são por isso mais verossímeis: "com pintar escrupulosamente os costumes de um povo, vocês acreditam que também as situações de suas tragédias devem ser mais originais e características. Tudo isso está bem quando a História deve servir ao objetivo da tragédia." O crítico acredita que a falha do sistema romântico está no fato que o Artista deve mostrar um grande talento na escolha de acontecimentos com potencial de render um verdadeiro efeito teatral. Caso isso não

\footnotetext{
${ }^{231}$ Paride Zaiotti. "Critica del sermone di Giovanni Torti 'Sulla Poesia' e delle 'Idee elementari sulla poesia romantica' di Ermes Visconti" (Biblioteca italiana, 1ำ trimestre de 1819) in Discussioni e Polemiche sul Romanticismo (1816-1826), volume 2, p. 13 (nossa tradução). "Gli italiani hanno ricevuto dai latini la mitologia come un patrimonio; quando essa cessò d'essere la religione dei popoli, fu confinata nei versi; ma, divenuta un linguaggio poetico, non può essere rigettata, se non da chi ignora che alle favole non si presta fede come a verità religiose, ma si consideravano come idoli della fantasia ed allegorie sapientissime."

${ }^{232}$ Edmondo Clerice. Op cit, p. 105 (nossa tradução)
} 
ocorra, adverte Molossi, "o seu zelo apaixonado pela História se transformará em uma verdadeira pedantaria, e, acreditando subtrair-se às regras, vocês tornar-se-ão majoritariamente escravos das regras." Como exemplo de sua argumentação, o crítico faz uma comparação entre o romântico Schiller e o clássico Alfieri:

(...) e uma das primeiras razões pelas quais foi censurada a Maria Stuart, de Schiller, e o seu Dom Carlos deve-se ao defeito do poeta de ser por demais preso à História. O Felipe do Dom Carlos, no juízo dos doutos, é muito inferior àquele de Alfieri, muito embora este último tenha sido concebido com o rigor de todas as regras. Somente esse exemplo bastaria para provar que uma reta observância das regras, ao invés de ser prejudicial, torna-se muito mais útil e necessária. ${ }^{233}$

Em outro artigo do Accattabrighe o anônimo articulista pondera "que o uso demasiado da Mitologia fosse fora de propósito, é uma verdade já ouvida há três séculos. Não é necessário que os românticos a recantassem como uma coisa nova." ${ }^{234}$ É possível inferir de tudo isso que muitas das questões levantadas pelos românticos não eram estranhas ao debate travado entre os classicistas no interior de suas academias. Porém, o que os fautores da nova escola desejavam era exatamente o Novo, ou seja, uma concepção artística que estivesse em consonância com os novos tempos. Em nossa hipótese de interpretação a contradição a qual não se furtou de incorrer II Conciliatore foi batalhar por uma renovação da cultura italiana na época da restauração do Antigo Regime.

Outra característica do movimento romântico italiano posta em realce por Edmondo Clerice foi a interação entre a Arte e a Vida. Para os fautores da nova escola era necessária uma ligação mais direta entre a produção literária e a vida cotidiana. II Conciliatore, como porta-voz dessas ideias, "junto com as novas

\footnotetext{
${ }^{233}$ Pietro Molossi. "Sulle unità drammatiche di luogo e di tempo" (Accattabrighe, gennaio-febbraio 1819) in Discussioni e Polemiche sul Romanticismo (1816-1826), volume 2, pp 48-49 (nossa tradução). "Coll'esser troppo fedeli nel rivelarci le più minute circostanze della storia, vol altri alemani credete già d'aver fatto un gran passo nella strada del verissimile; credete che, col dipingere scrupulosamente i costumi d'un popolo, anche le situazioni delle vostre tragedie debbano essere più originali e caratteristiche. Tutto questo va bene quando la storia debba servire allo scopo della tragedia; ma se voi, adoperando la storia, non fate scelta giudiziosa dei quadri che sono più a portata per l'effetto teatrale; se voi trascurare di disporre quei quadri nel modo più opportuno e più conveniente per illudere tutto, il vostro zelo appassionato per la storia si cangerà in una vera pedanteria, e, credendo di sotrarvi alle regole, voi diverreste maggiormente schiavi delle regole. (...) ed una delle principali ragioni per cui venne censurata la Maria Stuarda di Schiller, e il suo Don Carlos si deve al difetto del poeta di essersi troppo attenuto alla storia. II Filippo del Don Carlos, a giudizio dei dotti, è di molto inferiore a quello dell'Alfieri, sebbene quest'ultimo sia stato concepito col rigore di tutte le regole. Questo solo esempio basterebbe, per provare che una retta osservanza delle regole, anziché esser dannosa, diventa piuttosto utile e necessaria."

${ }^{234}$ Accattabrighe. "Ultimo articolo contro i romantici" ( $n^{\circ} 13$ del 28 marzo 1819) in Discussioni e Polemiche sul Romanticismo (1816-1826), volume 2, p 104 (nossa tradução). "Che il soverchio uso della mitologia andasse tolto, questa è una verità già da tre secoli sentita, nè d'uopo che i romantici ce la ricantassero qual nuova cosa."
} 
doutrinas estéticas, falou de argumentos morais e sociais, econômicos e históricos, manifestando em cada artigo, como sempre, um grande amor pela Itália e um desejo constante pela sua regeneração." 235 Como consequência dessa vontade expressa de devolver à Itália sua antiga posição entre as nações europeias, "o movimento romântico tendia por natureza própria a popularizar o Saber e a combater o classicismo refinado e perfeito, que havia transformado a Arte em uma coisa convencional e, por assim dizer, aristocrática." ${ }^{236}$ No entanto, para um classicista como Carlo Giuseppe Londonio, "se enganam aqueles que pretendem deva o Poeta servir ao gosto e aos preconceitos da multidão, porque em matéria de artes e letras o Povo não é juiz competente." O crítico acredita que o cidadão comum "não está apto a distinguir as belezas ou os defeitos de um quadro ou de uma estátua, assim igualmente não pode julgar o mérito de uma tragédia ou de um poema." ${ }^{237}$ Seria razoável supor que as diferenças entre românticos e classicistas se estendiam para além das fronteiras estéticas, por mais mal definidas que estas fossem. Muito embora existissem pontos de contato entre as duas correntes, como por exemplo o desejo de reerguer a cultura italiana, era notória a distância que separava as duas concepções de mundo.

Clerice recorda "os românticos italianos, antes da Folha Azul, tinham esporadicamente, e sem propor-se um objetivo determinado, acenado ao Romantismo em opúsculos e artigos." ${ }^{238}$ À guisa de esclarecimento sobre esse ponto citaríamos os escritos de Ludovido di Breme (Intorno all'ingiustizia di alcuni giudizi letterari italiani, junho de 1816), Pietro Borsieri (Avventure letterarie di un giorno, setembro de 1816), Giovanni Berchet (Lettera semiseria di Grisostomo, dezembro de 1816) ${ }^{239}$ todos colaboradores de // Conciliatore. Isso demonstra a exatidão do comentário de Clerice, para quem "a Folha Azul foi, para os literatos que a redigiam uma ocasião de se reunirem, de comunicarem e de discutirem as suas ideias." ${ }^{240}$ Nosso jornal foi um polo de atração e também de difusão das

\footnotetext{
${ }^{235}$ Edmondo Clerice. Op cit, pp 182-183 (nossa tradução)

${ }^{236}$ Idem, p. 129 (nossa tradução)

${ }^{237}$ Carlo Giuseppe Londonio. Op cit, p. 230 (nossa tradução). "E a gran partito s'ingannano coloro che pretendono il poeta debba servire al gusto e ai pregiudizi della moltitudine, poiché in fatto di arti e di lettere il popolo non è giudice competente; $\mathrm{e}$ in quella guisa che non è atto a distinguere le bellezze o i difetti d'un quadro o d'una statua non può giudicare del merito d'una tragedia o d'un poema."

${ }^{238}$ Edmondo Clerice. Op cit, p. 100 (nossa tradução)

${ }^{239}$ Esses artigos estão publicados na íntegra em I manifesti romantici del 1816 e gli scritti principali del "Conciliatore" sul Romanticismo.

${ }^{240}$ Edmondo Clerice. Op cit, p. 227 (nossa tradução)
} 
diversas tendências que compunham o movimento romântico da época, como explicou Silvio Pellico em uma carta a seu irmão Luigi, que acredita-se tenha sido escrita em outubro de 1818

Confalonieri e Porro eram nobres, não tinham contato com certos ultraliberais. Aproximaram-se e todo o desacordo desapareceu. Romagnosi pertencia a um grupo de pessoas que guardava rancor do grupo de Rasori. Aproximaram-se e todo o desacordo desapareceu. Berchet, De Cristoforis, Ermes Visconti, Torti formavam outra brigada que tinha rancor a Borsieri e a mim. Nos reconhecemos, justificamo-nos e estimamo-nos. Nos achamos todos quase da mesma natureza e da mesma crença. As pequenas diferenças serão sustentadas sem obstinação e o público, julgando tacitamente, se iluminará e dará a palma ao Verdadeiro. ${ }^{24}$

Edmondo Clerice atribui o fim de II Conciliatore, "àquelas suspeitas indeterminadas que naturalmente surgiam na cabeça dos funcionários austríacos à leitura dos artigos." Para ele as suspeitas, com o passar do tempo, transformaramse em certeza de que o periódico era o meio difusor de "uma trama real" contra o governo do Reino Lombardo-Vêneto. ${ }^{242}$ Essas suposições eram nutridas, em grande parte, pela reação do público à severa censura sofrida pelo jornal. Clerice conta "muitos, vendo os pontinhos, corriam ao editor Ferrario para ler os parágrafos suprimidos: as perseguições fizeram chover assinantes." 243 É possível inferir que a censura rigorosa do governo austríaco marcou II Conciliatore e o movimento romântico a ele associado como liberais e patriotas, profundamente empenhados na causa da modernização da Itália, tanto no plano econômico como em nível de sociedade. O pano de fundo dessa mobilização, bem percebido pela polícia austríaca, era a reunificação da Península.

\footnotetext{
${ }^{241}$ Apud Edmondo Clerice. Op cit, p. 11 (nossa tradução). "Confalonieri e Porro erano nobili, erano senza contatto con certi ultra-liberali. Si sono avvicinati e ogni disarmonia è sparita. Romagnosi teneva ad un crocchio di gente che guardava in cagnesco il crocchio di Rasori. Si sono avvicinati ed ogni disarmonia è sparita. Berchet, De Cristoforis, Ermes Visconti, Torti formavano un'altra brigata che guardava in cagnesco Borsieri e me. Ci siamo riconosciuti, giustificati e stimati. Ci siamo trovati tutti della stessa natura e della stessa credenza. Le piccole diversità saranno sustenute tutte senza accanimento e il pubblico tacitamente giudicando, si illuminerà e darà la palma ao vero."

${ }^{242}$ Edmondo Clerice. Op cit, pp 206-207 (nossa tradução)

${ }^{243}$ Idem, p. 66 (nossa tradução)
} 


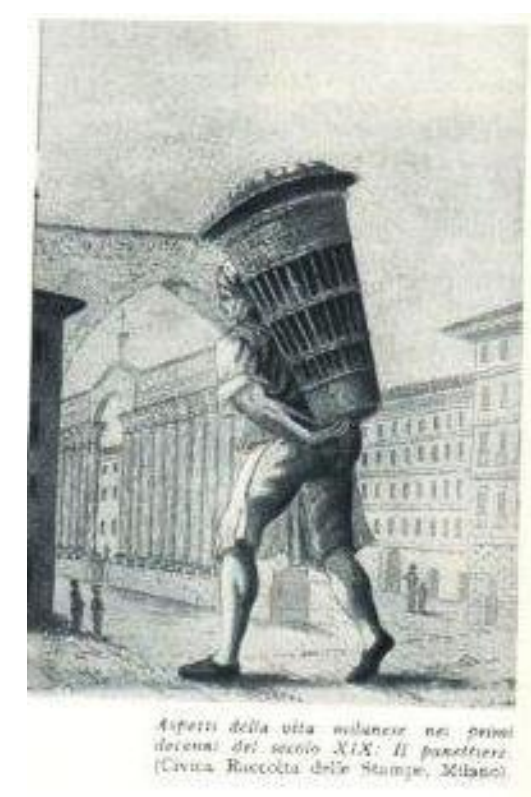

Cenas da vida milanesa nas primeiras décadas do século XIX: o entregador de pães (in Cesare Spellanzon. Storia del Risorgimento e dell'unità d'Italia, p.618)

A ação censória sofrida de forma permanente por I/ Conciliatore dificulta, na opinião de Edmondo Clerice, "o juízo sobre a obra dos nossos românticos" uma vez que eles não podiam expressar-se livremente e "nem todas as opiniões conseguiam escapar da censura e aparecer diante do público." 244 Porém é importante salientar, e Clerice na verdade o faz repetidas vezes, "que o movimento intelectual por nós examinado pode ser chamado primeiro romantismo italiano (romantismo lombardo ou romantismo de II Conciliatore), e é muito diferente do romantismo sucessivo chamado também de victorhuguiano ou francês." ${ }^{245}$ Acrescentaríamos que a partir da década de 1830 o movimento romântico italiano de fato ganhou outra perspectiva quando uma nova geração, que não vivera as guerras napoleônicas mas crescera em uma Itália dividida e governada em grande parte por estrangeiros, passou a lutar pela independência da Península, em um cenário político e cultural influenciado pelas revoluções liberais da década de 1820 e a insurreição francesa de 1830.

Em suas considerações finais, Edmondo Clerice alega "um juízo completo sobre a obra e sobre a eficácia dos colaboradores da Folha Azul apresenta sem dúvida dificuldades" ${ }^{246}$, opinião com a qual dificilmente deixaríamos de concordar. Escrevendo no início do século $X X$, o crítico disse

\footnotetext{
${ }^{244}$ Idem, p. 227 (nossa tradução)

${ }^{245}$ Idem, p. 162 (nossa tradução)

${ }^{246}$ Idem, p. 226 (nossa tradução)
} 
Muito embora quase um século já nos separe daquela primeira aparição do Romantismo na Itália é ainda difícil julgá-lo sem paixão e sem algum preconceito. O Romantismo, entre outras coisas, representa um progresso do Sentimento e, frequentemente, para poder julgar com mais propriedade certas manifestações é preciso senti-las: e como nem todos sentem da mesma maneira, nem todos, por isso concordam no juízo. ${ }^{247}$

E o que diríamos nós, que escrevemos duzentos anos depois daquela época? Que as paixões e os preconceitos que um dia envolveram o Romantismo há muito deixaram de existir. O que restou, e disso podemos dar testemunho, foram o respeito e a admiração por artistas e intelectuais que não se intimidaram diante das agruras de um momento histórico adverso e souberam, apesar de todas as contradições do seu tempo, construir uma identidade coerente com as suas ideias e principalmente com os seus sentimentos.

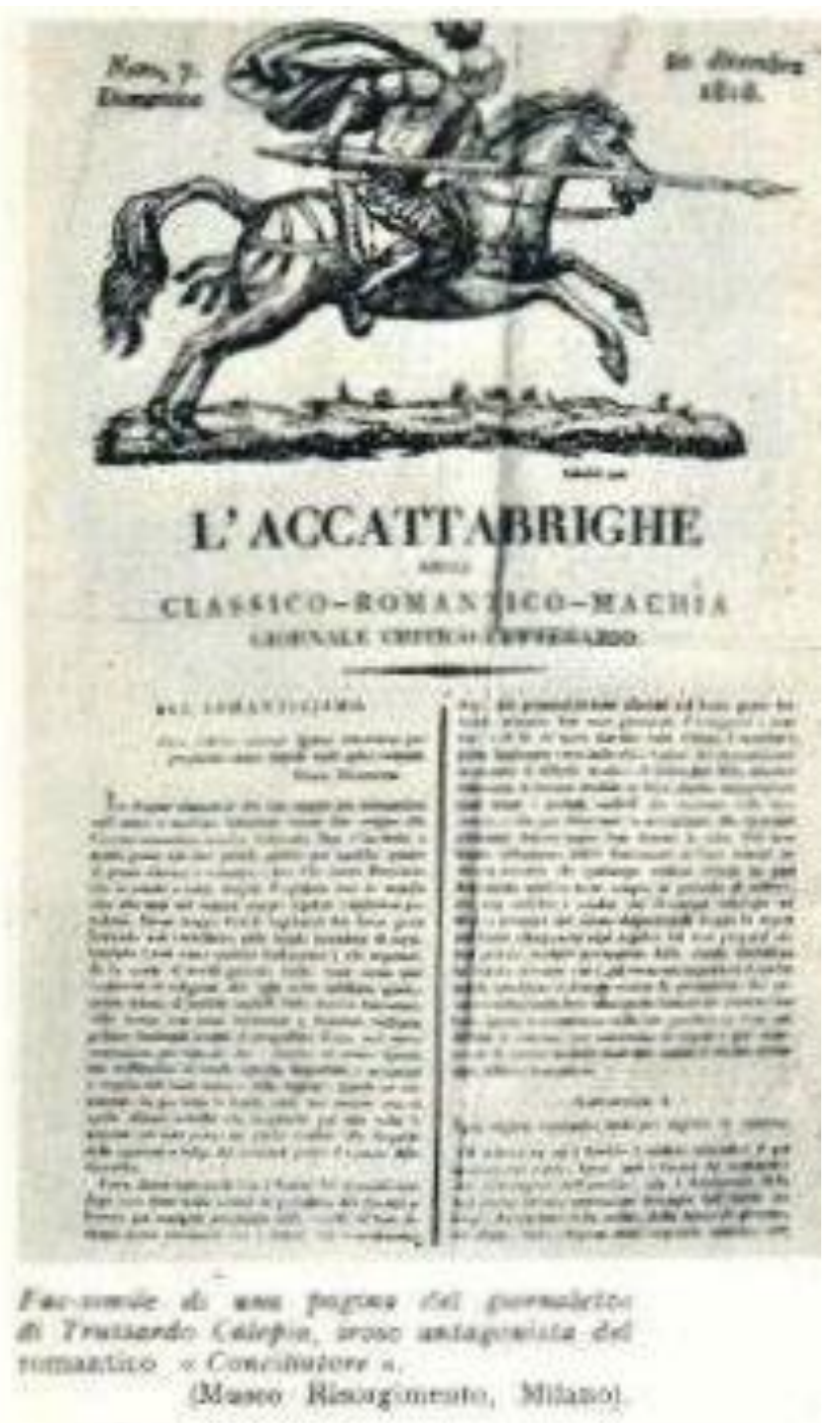

Fac-símile de uma página do jornal de Trussardo Calepio, L'Accatabrighe, fero antagonista de Il Conciliatore (in Cesare Spellanzon. Storia del Risorgimento e dell'unità d'Italia, p. 774)

${ }^{247}$ Idem, p. 229 (nossa tradução) 


\section{CAPÍTULO 4 ROMANTISMO E HISTÓRIA NAS PÁGINAS DE IL CONCILIATORE}

\subsection{A crítica romântica}

A nova abordagem estética proposta pelo Romantismo modificava a relação da crítica com a obra de arte. De acordo com Walter Benjamin, que realizou um estudo sobre o tema, os românticos divergiam dos classicistas por não aceitarem "a Forma como uma regra de beleza da Arte e sua observância como uma précondição necessária para o efeito agradável e edificante da obra." ${ }^{248}$ Assim sendo, enquanto os artistas classicistas devem exercer a sua criatividade dentro de padrões já estabelecidos (melhor dizendo, consagrados pela Tradição) os artistas românticos devem criar as formas através das quais se expressarão. Por essa razão, segundo o filósofo alemão, "o valor da obra depende única e exclusivamente do fato de ela em geral tornar ou não possível sua crítica imanente", ou seja, a obra só pode ser analisada em função dela mesma, e não de elementos exteriores à sua forma. Para os românticos, nas palavras de Walter Benjamin, "se uma obra é criticável, logo ela é uma obra de arte; de outro modo ela não o é." ${ }^{249}$ Se o crítico classicista analisava a obra em função da adaptabilidade do artista à uma forma pré-estabelecida pelos cânones clássicos, o crítico romântico deve primeiramente entender de que forma o artista construiu sua obra, já que, como observou Walter Benjamin, "a simples criticabilidade representa um juízo positivo sobre a mesma." ${ }^{250}$ Pode-se então concluir que no Romantismo a análise da obra é tão importante quanto a realização da mesma, sendo que Arte e Crítica estão no mesmo patamar.

Para que possamos avaliar a influência das concepções estéticas geradas na Alemanha ao final do século XVIII no pensamento italiano dos anos posteriores à Resturação de 1814, verifiquemos a crítica escrita por Ludovico di Breme sobre a novela $\mathbf{O}$ Giaurro, de Lord Byron, publicada pelo jornal II Spettatore, de Milão, em princípios do ano de 1818. O articulista declara que existem dois tipos de crítica literária: uma servil, que em suas palavras, "se opôs e se oporá sempre ao incremento das letras, das ciências e das artes; o seu baluarte consiste em uma imaginária perfeição já alcançada, além da qual não seria possível dar um passo."

\footnotetext{
${ }^{248}$ Walter Benjamin. 0 conceito de crítica de arte no romantismo alemão, p. 84

${ }^{249}$ Idem, p. 86

${ }^{250}$ Idem, ibidem.
} 
Reconhecemos nesse trecho o repúdio romântico aos cânones do Classicismo, que consideravam como arte apenas as expressões codificadas pela Tradição. Mas di Breme anuncia que existe uma outra crítica, séria, filosófica e incentivadora que "sabe não ser seu dever prescrever leis artificiais, nem impor obstáculos à faculdade criadora, mas caminhar atentamente sobre sua trilha recolhendo e entesourando os seus achados." 251 Ao finalizar dizendo que essa nova crítica tem como sede Edimburgo, na Escócia, assim como algumas cidades da Alemanha Superior que ele evita citar, o autor deixa claro que ela não existe na Itália. Implantá-la na Península será justamente a tarefa que Ludovico di Breme, Silvio Pellico, Ermes Visconti, Giovanni Berchet e Giuseppe Pecchio se proporão nas páginas de II Conciliatore.

Mario Fubini, em um ensaio escrito em 1951 (Stile critico del Berchet), distingue duas correntes no movimento romântico italiano: o romantismo prático e o romantismo teórico. ${ }^{252}$ Entre os românticos práticos o crítico elenca Alessandro Manzoni e os escritores ditos manzonianos e o grupo de II Conciliatore, do qual Giovanni Berchet fez parte. Para esses literatos o fazer artístico (poemas, romances, tragédias) não estava de forma alguma dissociado da reflexão crítica, muito pelo contrário: para eles o grande artista forjava o grande crítico e o grande crítico forjava o grande artista. Em sua análise do romantismo alemão, Walter Benjamin afirma "na arte romântica a crítica não apenas é possível e necessária, mas, antes, em sua teoria encontra-se de modo inevitável o paradoxo de uma valorização superior da crítica do que da obra." 253 Entendemos com isso que a tarefa do crítico é desvendar os processos criativos do artista (que, na teoria romântica, são na maioria inconscientes) e fazer uma anatomia da obra, expondoIhe as formas de maneira clara e objetiva. Assim, o crítico aponta os valores positivos e os pontos negativos do trabalho baseando-se nas propostas colocadas

\footnotetext{
251 "Ci ha due specie di critiche letterarie: l'una servile, sia per difetto di lumi e di sentimento, sia per difetto di buona fede e per ville traffico di adulazione; siffatta critica, siccome sempre si oppose, così si opporrà mai sempre all'incremento delle lettere, delle scienze e delle arti; il suo baluardo suol essere una certa sognata perfezione di già conseguita, oltre la quale non sia più possibile muovere un passo. (...) Un'altra critica invece, grave, avvivatrice degli ingegni e molto filosofica, sa di non dover prescriver leggi artificiali, nè imporre giochi alla facoltà inventrice, ma camminare attenta sulle di lei orme raccorglierne e tesoreggiare solecita i rotrovamenti; quest'altra critica nobile, liberale e giovevolissima, ha la sua sede oggedì in parecchie città della Germania Superiore, ed in Edimburgo nella Scozia." Ludovido di Breme. "Il Giaurro, frammento di novella turca scritto da Lord Byron (nello Spettatore, 1818, e poi in opuscolo. Milano: Pirotta, 1818)" in Discussioni e Polemiche sul Romanticismo (1816-1826), a cura di Egidio Bellorini, volume 1, p. 237 (nossa tradução)

${ }^{252}$ Mario Fubini. "Stile critico del Berchet" in Romantismo italiano, saggi di storia della critica, pp. 77 a 105

${ }^{253}$ Walter Benjamin. Op cit, p. 123
} 
na sua formatação. A crítica descobre na obra o seu paradigma interpretativo, tornando-se parte dela, já que o crítico constrói a ponte que liga o emissor ao receptor. Dessa maneira, o crítico precisa ser sensível e criativo; ele também é um artista. Já o artista deve possuir um pensamento crítico que lhe permita ordenar seus processos criativos de modo a elaborar novas formas de expressão. Em outras palavras, ele precisa ser um crítico. Outro aspecto relevante dessa simbiose entre Crítica e Arte é a visão romântica da Cultura como um elemento da formação cívica do Homem. O Indivíduo só pode tornar-se um cidadão consciente de seus direitos e de seus deveres (nos moldes propostos pela Revolução Francesa) quando ele partilha de um legado cultural comum a toda sua comunidade. Dessa forma, a Arte é um fator agregativo e a Crítica um meio de instrução. Nesse sentido tanto Natalino Sapegno 254 quanto Ettore Li Gotti 255 identificam no grupo de II Conciliatore uma forte tendência a considerar a educação moral do indivíduo o principal objetivo da obra de arte.

Ermes Visconti escreveu o ensaio mais elaborado sobre a estética romântica publicado por II Conciliatore: Ideias elementares sobre a poesia romântica apareceu em seis números do jornal (23, 24,25, 26, 27 e 28) entre os dias 19 de novembro e 06 de dezembro de 1818. As opiniões a respeito das habilidades críticas de Visconti não são unânimes. Por exemplo, Goethe, em artigo escrito em 1818 e vertido para o italiano em 1825 (Clássicos e românticos lutam acirradamente na Itália), analisou de forma sucinta para os leitores de língua alemã o debate crítico que era então travado na Península entre os fautores das duas escolas estéticas. Disse o grande gênio da arte romântica:

Como românticos práticos são dignos de elogio Giovanni Torti, por sua criação poética da Paixão de Cristo e por seus tercetos sobre a Poesia; e Alessandro Manzoni, autor da tragédia 0 Conde de Carmagnola, que granjeou fama com seus hinos sacros. Mas aquele de quem muitos esperam em termos de teoria crítica é Ermes Visconti, que escreveu um diálogo sobre as três unidades dramáticas, um artigo sobre o poético e as ideias sobre o estilo. Elogia-se nesse jovem sua grande perspicácia, uma

\footnotetext{
${ }^{254}$ Natalino Sapegno. Disegno storico della letteratura italiana ad uso delle scuole medie superiore, p. 559

${ }^{255}$ Ettore Li Gotti. G. Berchet - La letteratura e la politica del risorgimento nazionale (1783-1851), p. 158
} 
perfeita clareza nos pensamentos e um estudo aprofundado dos antigos, assim como dos modernos. ${ }^{256}$

Porém a avaliação goethiana não foi endossada pelos pósteros. Na virada do século XIX para o século XX, Giuseppe Antonio Borgese, em sua História da crítica romântica na Itália, declarou "Berchet, Pellico, Visconti, Torti, Manzoni e Rosmini são formuladores de regras (precettisti), e não críticos: raras são as críticas em seus escritos." 257 Tal opinião sobre a primeira geração romântica surgida na Itália nos parece algo depreciativa, pois desconsidera as limitações a que os introdutores de novos conceitos estão sujeitos. Lembremos que a grande obra teórica de matriz romântica nas letras italianas foi desenvolvida uma geração depois, já em meados do Oitocentos, nos trabalhos de Francesco de Sanctis. Contudo deve-se ressaltar em Ermes Visconti sua clareza de estilo assim como a objetividade de suas ideias. Mas a sua argumentação teórica não possui a profundidade de F. Schlegel (Conversa sobre a Poesia) ${ }^{258}$ ou F. Schiller (Poesia ingênua e poesia sentimental), ${ }^{259}$ autores de estudos teóricos na mesma orientação romântica.

Ideias elementares sobre a poesia romântica aparecem em meio aos debates, insultos e impropérios desferidos por românticos e classicistas no afã de manterem suas posições na batalha estético-ideológica que travavam naqueles anos. A primeira preocupação de Ermes Visconti é delinear os campos opostos: "a frase poesia romântica foi inventada na Alemanha para distinguir os caracteres próprios à arte dos poetas modernos da qualidade pertencente exclusivamente aos

\footnotetext{
256 "Come romantici pratici vengon lodati Giovanni Torti per la sua iscrizione poetica della Passione di Cristo, e per le sue terzine sopra la poesia; ed Alessandro Manzoni autore della tragedia II Carmagnola, che si è acquistato fama con i suoi inni sacri. Ma quegli dal quale ognuno molto si ripromette teoricamente è Ermes Visconti, che ha scritto un dialogo sulle tre unità drammatiche, un articolo sopra il poético, e idee sullo stile. Si loda in questo giovine grande acutezza di spirito, perfetta chiarezza ne' pensieri, e profundo studio degli antichi, come de' moderni." Goethe. "Classici e romantici lottano accanitamente in Italia - 1818 (Antologia, Dicembre 1825)" in Discussioni e Polemiche sul Romanticismo (1816-1826), volume 2, p. 477 (nossa tradução). Como tanto o diálogo sobre as três unidades dramáticas quanto as ideias elementares foram somente publicados em II Conciliatore inferimos que Goethe era leitor do jornal.

257 "Berchet, Pellico, Visconti, Torti, Manzoni, Rosmini sono precettisti, anzi che critici; rari sono i giudizi singoli nei loro scritti." G. A. Borgese. Storia della critica romantica in Italia, p. 250 (nossa tradução). O autor não poupa ácidos comentários sobre o grupo de II Conciliatore.

${ }^{258}$ Conversa sobre a Poesia é um ensaio de Friedrich Schelegel (1772-1829) que foi publicado nos dois últimos números da revista Athenäum do ano de 1800. Existe uma tradução em português do texto realizada por Victor-Pierre Stirnimann e publicada pela Editora Iluminuras em 1994.

${ }^{259}$ Esse texto de Schiller (1759-1805) apareceu em 1797 no número 11 da revista As Horas (Die Horen). Há uma tradução em português realizada por Márcio Suzuki e publicada pela Editora lluminuras em 1991.
} 
antigos clássicos." ${ }^{260}$ Aqui ele faz uma crítica aos fautores do Classicismo que se preocupam apenas em seguir modelos de inspiração greco-romana que não possuem pontos de contato com a realidade coeva, expressando-se através de uma linguagem fossilizada, morta. Para o autor, "os poetas devem ser homens, cidadãos e filantropos, não apenas doutores ou retóricos; o impulso poético deve nascer das sensações da vida e não das práticas de uma escola." ${ }^{261}$ Ou seja, dentro dos novos parâmetros sociais estabelecidos pela Revolução Francesa e, na Itália, pelo Império Napoleônico, os artistas precisam assumir seu papel na vida cotidiana, precisam deixar os salões da aristocracia e sair à rua para cantar os afazeres do povo. Por isso, continua Visconti, "não é por capricho que se insiste na exclusão do Classicismo, mas sim pela conviç̧ão de que é preciso abandoná-lo para que se possa tratar de coisas interessantes aos leitores." 262 O Interesse nasce da Realidade, de tudo aquilo que brota das ideias, das observações e das paixões da "vida real". Segundo o articulista, "os classicistas do mil e oitocentos não podem jamais ter sentido as coisas que tanto se esforçam para exprimir; vê-se assim o literato e não o homem." ${ }^{263}$ Dentro dessa teoria alguém que fosse dramatizar o assassinato de Júlio César (tal como fez Vittorio Alfieri em sua tragédia Bruto secondo $)^{264}$ e procurasse justificar as atitudes dos personagens históricos baseado somente nos escritos dos autores antigos seria um classicista, e deveria ser repreendido por sustentar seu enredo em "ideias antiquadas de povos extintos". Já aquele que argumentasse com noções de equidade e justiça, mostrando a face vergonhosa da empresa levada a cabo por aqueles personagens seria um romântico, pois projetaria um olhar moderno sobre um acontecimento antigo. Outro que se limitasse a narrar o episódio sem contudo nele inserir um ponto de vista pessoal, seja aprovando ou censurando a conduta dos personagens de sua

\footnotetext{
260 'La frase poesia romantica fu inventata in Germania per distinguere i caretteri propri dell'arte de' poeti moderni dalle qualità esclusivamente spettanti ai classici antichi (...)." Ermes Visconti. "Idee elementari sulla poesia romantica" in II Conciliatore, num 23 (19/11/1818), p. 89 (nossa tradução)

261 "(...) i poeti devono essere uomini, cittadini e filantropi, non meri dotti, né retori; l'impulso poetico deve nascere delle sensazioni della vita, e non dalle abitudini della scuola." Idem, ibidem

262 "Non per capriccio s'insiste sull'esclusione del classicismo, ma per convinzione che bisogna abbandonarlo, chi voglia trattare di cose interessanti ai lettori". Idem, p. 90 (nota)

263 "Non così i classicisti del mille ottocento diciotto, essi non possono aver sentito quelle cose che si sforzano d'esprimere, si vede il letterato e non l'uomo".ldem, num 24 (22/11/1818), p. 93

${ }^{264}$ Tragédia de Vittorio Alfieri (1749-1803), publicada pela primeira vez em Paris no ano de 1789.
} 
tragédia, faria uma obra que não pertence a nenhum dos dois sistemas (clássico e romântico), executando uma "poesia promíscua". ${ }^{265}$

Ermes Visconti ataca a pedantaria dos classicistas: admite-se apenas um único protagonista porque assim o fez Virgílio; termina-se um poema com uma digressão pois essa é a maneira de Horácio; mantêm-se as unidades dramáticas de tempo e de lugar já que o recomendou Aristóteles. Para ele, no entanto, "a pior, entre todas as deturpações do Gosto que podem ser imputadas ao Classicismo, foi, sem sombra de dúvida, a mania de restabelecer em nossos palcos as cortesãs, os servos e outros costumes de Plauto e de Terêncio" ${ }^{266}$ sob a alegação de que assim o fizeram os dois maiores comediógrafos romanos. Por isso a produção artística dos classicistas é em sua essência uma arte falsa, que não corresponde ao mundo no qual ela está inserida. Segundo Visconti, "a poesia clássica foi inspirada aos antigos por um entusiasmo original, e pode ser chamada de classicismo original. Nos modernos é um artifício escolástico que podemos chamar de classicismo irracional. Para fixar bem a diferença chamaremos de clássicos os gregos e romanos e qualificaremos os modernos como classicistas." 267 Outra distinção marcante entre clássicos antigos e classicistas modernos refere-se ao cenário das obras. O mundo dos modernos é muito mais amplo do que o dos antigos, uma vez que inclui as Américas, a África e a Ásia, mas os classicistas continuavam a cantar apenas as belezas naturais da Grécia e da Itália. Um evidente anacronismo empobrecedor de suas criações, que provocava críticas dos românticos.

Outro aspecto nocivo do Classicismo, de acordo com Ermes Visconti, é o uso de temas e personagens tirados da mitologia greco-romana nos enredos poéticos e dramáticos. Os românticos argumentavam que os povos europeus eram cristãos e por isso a sua concepção de divindade era totalmente diversa daquela dos antigos. Poucos meses antes da publicação do ensaio que aqui analisamos, Ludovico di Breme afirmara em sua resenha de $\mathbf{O}$ Giaurro, de Lord Byron, "a arte poética derivada de fontes mitológicas perdeu a sua eficácia, e já não mantém uma

\footnotetext{
${ }^{265}$ Idem, p. 94

266 "Il peggiore fra tutti gli stravolgimenti di gusto imputabili al classicismo fu senza dubbio la manìa di rifare sui nostri teatri le cortigiane, i servi, o altri costumi di Terenzio e di Plauto." Idem, ibidem

267 "La poesia classica veniva ispirata agli antichi da entusiasmo originale; può chiamarsi classicismo originale: ne' moderni è un artificio scolastico e si potrebbe distinguerla col nome di classicismo irragionevole. Anzi per fissare ancor più la differenza serberemo il titolo di classici ai Greci e Romani, e qualifecheremo i moderni con quello di classicisti." Idem, p. 95. Também nós, ao longo deste estudo, seguimos essa nomenclatura.
} 
influência verdadeira sobre os espíritos"; e apesar de muitos lamentarem esse fato, cabe aos letrados decidirem qual impulso criativo é mais verídico, aquele proveniente "dos auspícios cristãos e dos comportamentos psicológicos e naturais, ou aqueles que emergem dos exemplos de Júpiter com Ganimedes, de Hércules com as Tespíades ou das relações de Teseu com seu amigo Pirítoo..." ${ }^{268}$ Visconti argumenta que os europeus modernos herdaram as superstições medievais, uma vez que "as antigas fábulas setentrionais que falavam das feiticeiras, essas terríveis mensageiras, instrumentos de divindades tristíssimas, não desapareceram com o fim da idolatria, sofrendo apenas uma metamorfose para adaptarem-se ao corpo do novo culto." ${ }^{269}$ Além disso, os cruzados haviam trazido da Palestina, e difundido em seus países de origem, as fantasias orientais sobre fadas e gênios. Dessas duas fontes (o Setentrião europeu e o Oriente próximo) procedem, por exemplo, as bruxas de Shakespeare e os encantamentos de Ariosto. Na opinião de nosso crítico, "o heroísmo dos cavaleiros andantes veio ao encontro de um ideal de natureza humana concebido pelos europeus da ldade Média, inspirado pelas condições políticas, pelas tendências religiosas e pelos acontecimentos nacionais." 270 Por essa razão a poesia que está mais próxima dos tempos modernos não é aquela produzida na Grécia ou em Roma (por mais bela e perfeita que ela seja), mas sim a dos prosadores medievais, cujo impulso criativo já obedece à nova dinâmica sociocultural imposta pelo Cristianismo. Acrescente-se ainda, segundo Visconti, "dos provençais até nós o sentimento do amor desenvolveu-se com muito mais eficácia do que na Grécia ou em Roma." ${ }^{271}$ Isso fez com que os enredos da poesia épica, lírica e dramática elaborados pelos românticos fossem muito mais ricos e complexos

\footnotetext{
268 "O l'arte poetica derivata dalla fonte mitologica ha oramai perduto la sua efficacia, e le impressioni sue non serbano più influsso veruno sopra gli animi; e allora dirò che di ciò appunto van lamentadosi quelli che hanno la poesia mitologica per un inutile balocco, e che vedono distrutto questo già splendido espediente di nobili piaceri e di sociali sentimenti. $\mathrm{O}$ invece ella produce tuttavia delle forti commozioni e attegia tuttavia le nostre fantasie e riverbera su nostri costumi; e in quel caso decida l'uomo assennato quali sieno più da promuoversi, o invece da temersi, se quelli influssi che tornano dai fasti cristiani e dagli espediente psciologici e naturali, ovvero quelli che emergeranno dagli esempi di Giove con Ganimede, di Ercole colle Tespiadi, di Teseo in favore dell'amico Piritoo (...)" Ludovico di Breme. Op cit, p. 274

269 "Però le antiche favole settentrionali sulle streghe, terribili messaggere e strumenti di tristissime deità, non cessarono coll'idolatria, subirono soltanto una metamorfosi per adattarsi all'insieme del nuovo culto". Ermes Visconti. Op cit, num 25 (26/11/1818), p. 97

270 “(...) L'erosimo cavalleresco fu all'incontro un ideale di natura umana concepito dagli europei del medio evo, ed ispirato dalla condizione politica, dalle tendenze religiose e dagli avvenimenti nazionali." Idem, ibidem

271 "Dai Provenzali fino a noi il sentimento dell'amore si è sviluppato con più efficacia che non in Grecia ed in Roma." Idem, p. 98
} 
do que aqueles criados pelos antigos. Nosso crítico diz "quando os antigos ideavam uma situação na qual o afeto entrasse em oposição aos deveres, eles expunham esse combate interior do espírito mais sucintamente e mais superficialmente do que os modernos (...). Nós não admitimos o Destino dos gregos, que um homem possa ser punido pelo céu por erros involuntários, como Édipo." 272 Tudo isso somado levou os românticos a repudiarem a mitologia greco-romana como fonte de inspiração poética e a buscarem na Idade Média e na Cavalaria cenários mais verossímeis para suas obras de ficção.

A ideia basilar dentre as "ideias elementares" de Ermes Visconti é a atualização da literatura italiana. Para os românticos a Arte deve expressar o momento histórico no qual o artista está inserido. O poeta tem de criar sua obra inspirado pela vida cotidiana, transformada em paradigma. Por isso Visconti nos diz "o classicismo em Homero e em Sófocles corresponde ao romantismo em Schiller e em Milton; um e outro são efeitos de uma causa idêntica, qual seja, o entusiasmo espontâneo gerado e alimentado pelo todo da respectiva civilização." O Romantismo, assim compreendido, não é uma recusa pura e simples aos enredos e personagens da cultura clássica, mas um elemento que serve para atualizar, para mostrar um mundo que não cabe mais nos moldes da estética renascentista, de matriz greco-romana. Nosso autor reconhece que "é somente o classicismo dos modernos que merece reprovação, uma vez que é uma imitação inoportuna não da natureza em si, mas de obras de arte pré-existentes." ${ }^{273} \mathrm{E}$ ainda preocupado em responder aos críticos que insistem em dizer que os românticos são fautores da cultura germânica em detrimento da herança cultural latina (ou seja, são eles os novos bárbaros), Visconti afirma "as teorias dos assim chamados inovadores não são um meio termo para subtrair-se às regras: são apenas uma forma de superar os

\footnotetext{
272 "Quando gli antichi ideavano una situazione in cui l'affetto si opponesse ai doveri esponevano il combattimento interiore dell'animo più succintamente e più superficialmente de' moderni (...). Noi non ammetiamo il fato de' Greci, nè che un uomo possa essere punito dal cielo per falli involuntari, come Edipo." Idem, p. 99

273 "II classicismo in Omero ed in Sofocle corrisponde al romantismo in Schiller ed in Milton; l'uno e l'altro sono effetti di un'indentica causa, cioè dell'entusiasmo spontaneo voluto ed alimentato dal complesso della civilizzazione rispettiva. È il solo classicismo de' moderni che merita biasmo, perché è un'imitazione inopportuna non della natura, ma di preesistenti opere d'arte." Idem, num 27 $(03 / 12 / 1818)$, p. 105 . Cabe ressaltar que as noções clássicas renascentistas, tão exaltadas pelos classicistas italianos do século XIX, foram geradas através da releitura de obras da Antiguidade. É claro que essa releitura foi também influenciada pelo contexto histórico e cultural no qual ela foi realizada (início do século XVI).
} 
obstáculos impostos pela Pedantaria." ${ }^{274}$ E aqui está, em nosso entendimento, a chave para se compreender o romantismo italiano: não se trata, como na Alemanha, de uma renovação de paradigma, de uma recusa total dos modelos impostos pelo Classicismo. $\quad \mathrm{Na}$ Itália procurou-se inovar o paradigma, introduzindo novos elementos, sem contudo abalar as estruturas do edifício clássico. Se o romantismo alemão é uma obra de arquitetura, o romantismo italiano é uma obra de decoração.

$\mathrm{O}$ classicista Paride Zaiotti ${ }^{275}$ respondeu às ponderações de Ermes Visconti num artigo publicado na Biblioteca italiana no primeiro trimestre de 1819 (Crítica do sermão de Giovanni Torti "sobre a Poesia" e das “ideias elementares sobre a poesia romântica" de Ermes Visconti). Vale a pena conhecermos alguns de seus argumentos para que tenhamos uma noção mais clara do debate. Diz Zaiotti:

A forma exterior é na verdade o pomo da discórdia, já que nós não
conhecemos nenhum argumento que seja romântico por si mesmo. Ao
contrário, nós é que temos que replicar a todo momento: jovens poetas,
procurem os temas de seus cantos onde mais Ihe agrade: antigo ou
moderno, histórico ou fabular, pátrio ou estrangeiro, não importa; mas
recordem-se dos modelos antigos, e das regras, aquelas que o consenso
das nações a experiência nos transmitiram. Imitem a natureza, mas como
a imitaram os antigos, acolhendo as mais belas partes e dando mais
relevância à beleza do que à verdade escrupulosa. Investiguem os motivos
pelos quais são imortais os poemas de Homero e de Virgílio, e quando
forem capazes de descobri-los vocês terão aprendido as poéticas de
Aristóteles e de Horácio sem que jamais tenham lido nem Horácio nem
Aristóteles. ${ }^{276}$

Voltamos aqui ao problema da Forma, tal como exposto inicialmente quando evocamos Walter Benjamin. Os classicistas insistiam em que a beleza da obra de arte estava na maneira como ela era executada: uma vez que os gregos e romanos alcançaram uma beleza incomparável, segui-los escrupulosamente era certeza de criar um belo semelhante. Os românticos não aceitavam a Forma como critério estético. Para eles a obra de arte deveria ser avaliada pela originalidade da

\footnotetext{
274 'Le teorie de' così detti novatori non sono un mezzo termine per sottrarsi alle regole; dispensano soltanto dagl'impicci della Pedanteria."Idem, ibidem.

${ }^{275}$ Paride Zaiotti (Trento 8/6/1793 - Trieste 29/12/1843) colaborou na Biblioteca italiana, de Milão, e na Enciclopedia italiana, de Veneza.

276 "Questa forma esteriore è appunto il pomo della discordia, giacché noi non conosciamo alcun argomento romantico per se stesso, ed anzi ne giova replicare ad ogni momento: o giovani poeti, prendete il soggetto dei vostri canti dove vi piace: antico o moderno, storico o favoloso, patrio o straniero non importa; ma ricordatevi degli antichi modelli, e delle regole, che il consenso delle genti e l'esperienza ne trasle: imitate la natura; ma come la imitarono gli antichi, accogliendo le parti più belle e più alla bellezza intendendo, che ad una verità scrupolosa: investigate i motivi, per cui sono immortali i poemi d'Omero e di Virgilio; e quando sarete giunti a scoprirli, avrete imparata la poetica d'Aristotile e d'Orazio, senz'aver mai letto nè Orazio né Aristotile."Paride Zaiotti. "Critica del sermone di Giovanni Torti 'sulla Poesia' e delle 'idee elementari sulla poesia romantica' di Ermes Visconti. (Biblioteca italiana, $1^{\circ}$ trimestre 1819)" in Discussioni e Polemiche sul Romantismo (1816-1826), a cura di Egidio Bellorini, volume 2, p. 20 (nossa tradução)
} 
expressão artística, pois o verdadeiro gênio não imita, ele cria os seus próprios meios de expressão. Os classicistas italianos consideravam-se herdeiros e guardiões de uma cultura de inspiração clássica gerada na Península durante a Renascença. Os românticos achavam essa herança um fardo e chamavam de pedantes aqueles que teimavam em cultuá-la. Os adeptos do Classicismo diziam que as ideias românticas formavam um corpo estranho na cultura italiana, já que expressavam usos e costumes alheios ao povo peninsular. Os românticos contraatacavam argumentando que a imitação dos modelos clássicos fossilizara a produção artística na Itália e fizera com que esta perdesse a relevância que tivera em idos tempos no cenário cultural europeu. Num contexto político conturbado como aquele vivido na Península nos anos posteriores ao Congresso de Viena, tal debate ideológico tinha tudo para ser explosivo.

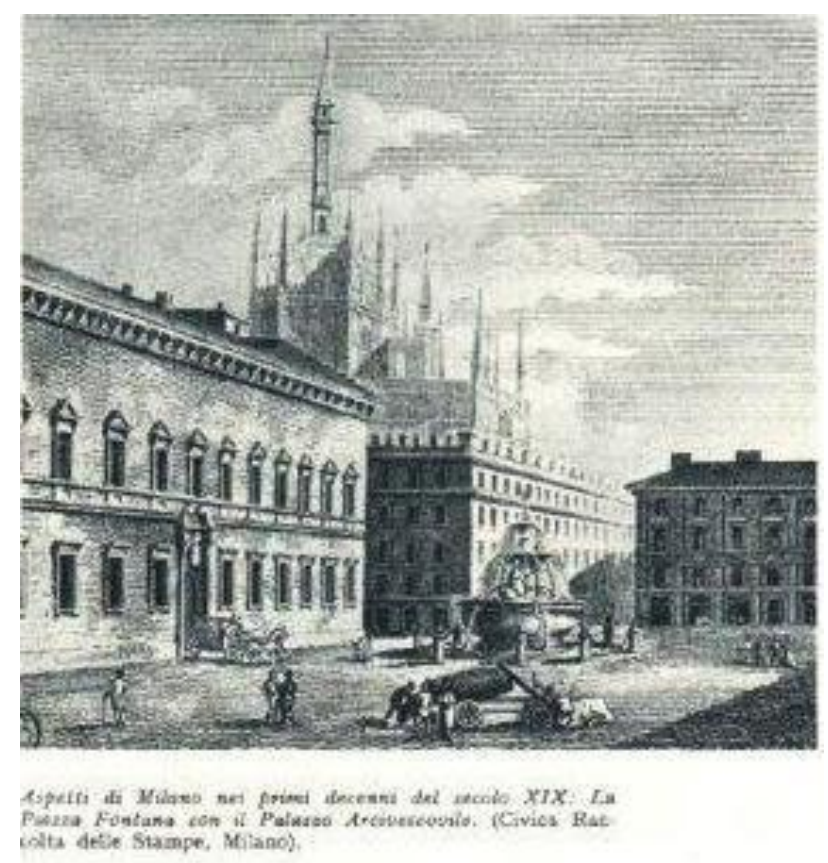

Vista de Milão nas primeiras décadas do século XIX: Piazza Fontana com o Palácio Arcebispal (in Cesare Spellanzon. Storia del Risorgimento e dell'unità d'Italia, p. 616) 
Vejamos agora como alguns dos temas abordados por Ermes Visconti aparecem em artigos de outros membros do grupo de II Conciliatore. ${ }^{277} \mathrm{O}$ primeiro ponto nevrálgico no debate entre classicistas e românticos era a atualização da poesia. Um dos pilares teóricos do Classicismo era a sua universalidade: as regras do Belo eram válidas para todos os artistas, não importando a sua época ou origem. Os românticos opuseram a isso a ideia da cor local e o conceito de época histórica. Dessa forma a produção artística ganhava contornos diferenciados, uma vez que se posicionava em relação ao seu lugar e ao seu tempo. Gian Domenico Romagnosi, indagado se era romântico ou classicista, retrucou: "sou ilichiastico, se quer que me expresse em grego, ou seja, sou adaptado às idades (...). Eu não sou nem desejo ser romântico ou clássico, mas sim adaptado aos tempos e às necessidades da Razão, do Gosto e da Moral." 278 Três faculdades do Espírito que variam bastante em função dos povos, dos lugares e das épocas históricas. Giovanni Berchet, que continuou a usar nas páginas de II Conciliatore seu famoso pseudônimo de Grisostomo, também considerava que o Poeta só atinge o sublime, que deve ser o objetivo de toda a poesia, "quando leva em consideração o caráter da sua nação e do seu século, e não o rejeite desdenhosamente como um elemento inoportuno aos seus propósitos poéticos. A poesia dos grandes poetas da Itália é poesia nacional no espírito do século no qual eles viveram." 279 Por isso os românticos eram contra modelos pré-estabelecidos: para eles a forma do Belo era a expressão de uma época e por isso não poderia ser imitada. Em outro número do jornal, Berchet voltou a tratar do mesmo tema quando afirmou que a Poesia só é eficaz, ou seja, só cumpre seus objetivos se "está de acordo com as ideias e as circunstâncias dos tempos nos quais vive o poeta." 280 Fica explícita a ideia de que a poesia de Homero,

\footnotetext{
277 A historiografia italiana denomina os intelectuais que escreveram em nosso periódico de i conciliatori (os conciliadores)

278 "Sono ilichiastico, se vuoi che te lo dica in greco, cioè adattato alle età (...). lo non sono nè voglio essere nè romantico, nè classico, ma adattato ai tempi ed ai bisogni della ragione, del gusto e della morale." Gian Domenico Romagnosi. "Della Poesia considerata rispetto alle diverse età delle nazioni." Num 3 (10/09/1818), p. 11 (nossa tradução)

279 "(...) Quando tien conto del carattere della sua nazione e del suo secolo, e non lo ributta sdegnosamente come inopportuno ai suoi intendimenti poetici. La poesia de' poeti sommi d'Italia è poesia nazionale nello spirito del secolo in cui essi vivevano." Grisostomo (Giovanni Berchet). "Storia della Poesia e della Eloquenza, ec di Bouterwek - parte prima. Letteratura italiana." Num 21 (12/11/1818), p. 83 (nossa tradução)

280 " (...) non potere essere sommamente efficace la poesia, se non è in accordo colle idee e colle circostanze de' tempi ne' quali vive il poeta." Grisostomo (Giovanni Berchet). "Poesias selectas castellanas, desde el tiempo de Juan de Mena hasta nuestros dias, etc - Poesia scelte castigliane, dai tempi di Giovanni de Mena ai giorni nostri, raccolte ed ordinate da don Emanuele Giuseppe Quintana. Madrid ec ec.”Num 99 (12/08/1819), p. 400 (nossa tradução)
} 
Virgílio, Dante, Tasso e outros imortais da literatura sobreviveu aos tempos porque expressou sua própria época e não porque ateve-se a modelos descritos em poéticas. Assim, para os românticos, a beleza da obra de arte não está em sua forma, mas em sua capacidade de exprimir o momento histórico no qual ela é realizada. ${ }^{281}$

Outro foco de discórdia era a língua. Os classicistas consideravam a Itália herdeira natural da cultura greco-romana, daí o seu apego ao latim e ao grego antigo. Gian Domenico Romagnosi, opondo-se a essa tendência, afirma "depois da mistura dos povos germânicos com os filhos degenerados dos romanos iniciou-se uma nova geração de Italianos, da qual nós descendemos em linha direta; e não é possível considerar-nos, falando em termos precisos, como uma nação de origem latina." ${ }^{282}$ É um argumento histórico que denuncia a ausência de veracidade factual nos argumentos dos classicistas. Ou seja, para os românticos fica claro que buscar as origens da cultura italiana é remeter-se à Idade Média, ao que eles chamavam de "espirito cavaleresco" da poesia medieval, em contraponto ao "espírito heroico" da poesia antiga. Os menestréis cantaram diferentemente dos aedos porque a vida nas cortes e cidades da Europa medieval nada tinha em comum com a vida nas cortes e cidades na Antiguidade. Giovan Battista de Cristoforis aprofunda um pouco mais a questão ao ponderar "os frutos preciosos da Poesia não são colhidos quando os fazemos falar uma linguagem conhecida apenas pela classe daqueles versados nos estudos das fábulas, cuja crença não se conecta mais com a nossa vida social." Mais uma vez discute-se a atualização da Arte, exigindo-se que os artistas escolham seus temas dentre os acontecimentos mais próximos da vida coeva, de modo a representar sentimentos e opiniões consoantes com a realidade vivida pelo público. Por que foi exatamente isso o que os grandes mestres da Antiguidade fizeram, segundo de Cristoforis: "que os egrégios antigos tenham escolhido como argumento de seus poemas a religião, os acontecimentos, as opiniões, os costumes, os vícios e as virtudes dos Gregos e dos Romanos será dever dos modernos, se quiserem ser verdadeiros imitadores daqueles talentos sublimes, renunciarem às imagens para

\footnotetext{
${ }^{281}$ Vale ressaltar que esse ponto de vista constitui o eixo central de duas obras fundamentais para a estética romântica, ambas escritas na década de 1820: Racine e Shakespeare, de Stendhal (1823) e Do Grotesco e do Sublime, de Victor Hugo (1827).

282 '(...) dopo la mescolanza de' popoli del nord co' tralignati figli de' Romani si è cominciata una nuova generazione d'Italiani, dalla quale noi deriviamo in retta linea; e che non può considerarsi, esattamente parlando, come una nazione d'origine latina." Gian Domenico Romagnosi. Op cit, p. 12 (nota)
} 
nós sempre frias, e frequentemente ridículas, da apagada mitologia." Note-se aqui a inversão do raciocínio, já que estará mais perto do ideal clássico aquele que mais se aproximar das propostas românticas, uma vez que o Romantismo pretende evocar o espírito de sua época. De Cristoforis continua dizendo em seu artigo que os poetas italianos devem adotar em suas obras "o nosso modo de sentir e as nossas crenças, que são muito diferentes dos antigos. E utilizar a nossa língua, assim como as nossas coisas, e não as dos outros para dar um interesse universal às suas composições." ${ }^{283}$ É outra inversão do argumento classicista, pois para seus fautores o uso de uma língua comum (o Latim) assim como de um mesmo paradigma (a Mitologia) dava às suas obras uma aceitação muito mais ampla, já que não estariam restringidas por fronteiras ou idiomas.

Os intelectuais que se opuseram à aristocracia dominante nos estados italianos no início do século XIX apoiaram a invasão francesa de 1805 por considerarem Napoleão Bonaparte um libertador. Com a divisão da Península em Reino da Itália e Reino de Nápoles a grande maioria desses apoiadores formou a burocracia das administrações de Eugênio Beauharnais e de Joaquim Murat. No ambiente cultural da Restauração essa elite letrada, então alijada do poder e sob estrita vigilância policial (principalmente por parte do governo austríaco do Reino Lombardo-Vêneto), tornou-se a porta-voz da classe média que havia ascendido, econômica e culturalmente, durante a ocupação napoleônica (1805-1813). Eram médicos, advogados, empregados de casas bancárias, comerciantes, que consumiam bens culturais mas não falavam latim, e por isso sentiam-se discriminados por uma produção cultural que não se expressava em língua italiana. Vários membros do grupo de II Conciliatore (Berchet, Visconti, de Cristoforis, Borsieri) haviam sido empregados públicos no Reino da Itália e por isso nosso periódico assumiu uma posição radical contra o uso do latim pelos classicistas.

\footnotetext{
283 “I frutti preziosi della Poesia non si raccolgono facendole parlare un linguaggio noto soltanto alla classe de'pochi versati negli studi della favola, ed appoggiandola a maraviglie, la credenza delle quali non va più congiunta col nostro viver sociale. Che se gli egregi antichi fecero argomento dei loro poemi la religione, gli avvenimenti, le opinioni, i costumi, i vizi, e le virtù de' greci e dei romani, per la stessa ragione sarà dovere dei moderni, volendo essere giusti imitatori di que' sommi ingegni, il rinunciare alle immagini per noi sempre fredde, e sovente ridicole della spenta mitologia; la adottare tenacemente il nostro modo di sentire e di credere assai diverso dall'antico; il servirse in somma come della lingua nostra, così anche delle cose nostre e non dell'altrui per dare importanza d'interesse universale di componimenti." Giovan Battista de Cristoforis. "Sulla Poesia, sermoni di Giovanni Torti. Milano 1818, dalla tipografia di Vincenzo Ferrario." Num 6 (20/09/1818), p. 22 (nossa tradução). II Conciliatore era impresso nessa mesma tipografia.
} 
${ }^{284}$ Pietro Borsieri lembra "os primeiros poetas foram venerados pelos povos primitivos como homens inspirados e santos por que em nome dos deuses proclamavam leis, estabeleciam ritos e, ao celebrar as virtudes guerreiras assim como a doçura dos afetos domésticos, eles resgatavam a Humanidade dos hábitos da vida selvagem." No mundo coevo a Poesia, segundo o autor, perdeu a força como elemento de transformação do Homem, que possuíra nos tempos de Orfeu, e também já não sente mais a influência religiosa que animava as obras de Dante e de Torquato Tasso. Para Borsieri a Poesia "rebaixou-se à vil condição de ser uma arte de puro prazer, destinada a adular o tédio dos grandes e o ócio dos vagabundos." 285 É necessário uma nova arte, que exprima o comprometimento dos artistas com a sociedade na qual eles estão vivendo. Aqui aparece o elemento moral do romantismo italiano, que já em seus primórdios se achava empenhado com o processo de reunificação da Itália, o Ressurgimento. Tanto é que Silvio Pellico adverte ser "passada a época das idolatrias estúpidas e dos elogios estéreis. Ao bom cidadão que dorme em sua tumba são inúteis os monumentos e os poemas; não é a ele que devemos cultuar: as honras que lhe tributamos seriam pueris se não tivessem como objetivo acender nos viventes e nos pósteros o desejo de elevar-se à altura daquele grande homem.” ${ }^{286}$ Na visão romântica, já contaminada pelo espírito liberal que inflamara a Revolução Francesa, não se deve celebrar o Homem, mas os seus feitos: o grande homem é aquele que devota a sua vida a uma grande causa. Pellico, cobrando dos literatos um engajamento explícito, afirma "nas bibliotecas só podem existir três tipos de livros, tirando os meramente científicos - aqueles que predispõe á virtude - aqueles que não proporcionam ao Homem nenhuma melhora

\footnotetext{
${ }^{284}$ Para o surgimento da classe média e o desenvolvimento de novos paradigmas culturais ver Peter Gay. A experiência burguesa da Rainha Vitória a Freud, volume 1, A educação dos sentidos. Para uma visão mais aprofundada sobre as mudanças sócio-políticas na Itália durante as duas primeiras décadas do século XIX consultar Stuart J. Woolf. "La storia politica e sociale" in Ruggiero Romano e Corrado Vivanti (org). Storia d'Italia, volume terzo, Dal primo settecento all'unità.

285 "I primi poeti furono venerati dagli antichissimi popoli come uomini ispirati e santi, perché in nome degli dei proclamavano leggi, stabilivano riti, e celebrando le virtù guerrieri o la dolcezza degli affetti domestici ritraevano l'umanità dall'errore ferino della vita selvaggia. (...) é discesa alla ville condizione di essere un'arte di puro piacere, destinata a blandire le noie de' grandi e l'ozio degli sfaccendati." Pietro Borsieri. "Sullo spirito profetico de' poeti." Num 8 (27/09/1818), pp. 31-32 (nossa tradução)

286 "È passata l'età delle stupide idolatrie, degli stereli elogi. Al buon citadino che dorme nella tomba sono inutili i monumenti e i poemi; non è per lui che dobbiamo ergere un culto: gli onori che gli tributiamo sarebbero puerili se non avessero lo scopo d'accendere ne' viventi e ne' posteri il desiderio d'elevarsi all'altezza di quel grande." Silvio Pellico. "Human Life, ec - La vita umana. Poema di Samuele Rogers. Londra, 1819." Num 103 (26/08/1819), p. 416. (nossa tradução)
} 
- e aqueles que o corrompem." 287 Nos tempos de II Conciliatore, que eram os tempos da Restauração e da Santa Aliança, tornar-se súdito ou cidadão; apoiar a República ou o Império; ser classicista ou romântico não eram escolhas simplesmente estéticas.

Gian Domenico Romagnosi acredita que não é possível "desejar que um italiano seja totalmente clássico" pois isso significaria que tal indivíduo ocupar-se-ia, quase exclusivamente, em copiar diplomas, elaborar árvores genealógicas, em vestir-se de maneira um tanto quanto antiquada e interessar-se por medalhas, vasos, talhas e armaduras. Para Romagnosi, tornar-se um classicista era negligenciar o cultivo de suas propriedades, não possuir em casa nenhuma das comodidades modernas e negar aos filhos o acesso à educação contemporânea. Tal pessoa seria uma aberração social. No entanto, para o articulista, querer que um italiano seja inteiramente romântico "é querer que ele abjure a própria origem, repudie a herança de seus maiores para ater-se apenas às novas reminiscências, especialmente as germânicas." 288 Devemos então concluir que, em estado puro, não deveriam existir classicistas e românticos em número expressivo na Itália. Silvio Pellico, ao resenhar um livro do poeta inglês Thomas Campbell, informa aos leitores "a diferença que existe entre clássico e romântico na Inglaterra não é a mesma que se estabeleceu entre nós." Os classicistas e os românticos ingleses estão de acordo em que, uma vez que o poeta sinta-se inspirado e componha uma obra original, o argumento, seja ele antigo ou moderno, não tem importância. Mas na Inglaterra, ao contrário da Itália, os fautores da escola clássica evitam assuntos gregos e latinos para não correrem o risco de reproduzir de forma assaz servil aquilo que pode ser lido em Homero, Virgílio e Horácio. Procuram então seus argumentos poéticos nos primórdios da Idade Média pois consideram, assim como os românticos, que os acontecimentos daquela época, mais ligados à nossa religião e à nossa cultura, possuem um interesse maior para os leitores. Não há objeção ao uso da Mitologia, seja por classicistas ou por românticos, uma vez que a composição revele originalidade, ou seja, expresse a individualidade de seu criador. Pellico termina sua resenha afirmando "o Tempo, que dissipa todos os erros, demonstrará que os

\footnotetext{
${ }^{287}$ Nelle biblioteche potrebbero venir distinte tre sole classi di libri, prescindendo dai meramente scientifici: - quelli che dispongono alla virtù - quelli che non portano l'uomo a niun miglioramento - e quelli che lo corrompono." Idem, p. 417

288 "Volere poi che egli sia affatto romantico, è volere ch'egli abiuri la propria origine, ripudi l'eredità de' suoi maggiori per attenersi soltanto a nuove rimembranze specialmente germaniche." Gian Domenico Romagnosi. Op cit, pp. 11-12
} 
românticos italianos não foram assim tão ridículos quando manifestaram o desejo de que a literatura de sua pátria influísse de maneira eficaz no aprimoramento moral da nação; e se permanecerem na Itália as denominações de clássico e romântico elas não se referirão mais a dois partidos discordantes mas apenas (como atualmente na Inglaterra) a duas doutrinas literárias, uma das quais procura emular os antigos em um tipo de Belo cujo atributo principal é o Simples, e a outra que busca revigorar uma espécie de Belo cujo atributo principal é o Singular." 289 Mais uma vez parece nítida a ideia de que para os românticos italianos, representados no grupo de II Conciliatore, não existia contradição explícita entre Classicismo e Romantismo como na Alemanha e na França. Para os peninsulares, romântico é um elemento da obra de arte, que a aprimora e a torna mais próxima do público coevo.

II Conciliatore, como porta-voz do movimento romântico italiano, se propôs a divulgar na Península as obras literárias produzidas na Alemanha e na Inglaterra de modo a colocar a intelectualidade local em sintonia com a cultura europeia. Quando o periódico surgiu, em setembro de 1818, eram já passados vinte anos da primeira grande onda romântica. Foi em 1798 que apareceu na Alemanha a revista Athenäum, editada pelos irmãos Friedrick e August-Wilhelm Schlegel, que desempenhou o mesmo papel que II Conciliatore desejava exercer na Itália. Ainda em 1798 foram publicadas, na Inglaterra, as Lyrical Ballads de Samuel Taylor Coleridge e William Wordsworth, um marco importante na história do Romantismo. O livro de Madame de Staël, De l'Alemagne, fora escrito por volta de 1810, porém enfrentou uma série de problemas com a censura do Império Napoleônico e apenas em 1814 foi editado em Londres. Além disso, a filosofia de Kant assim como a dos filósofos pós-kantianos do início do século XIX eram praticamente desconhecidas na Itália. E William Shakespeare era considerado um talento menor quando comparado a Vittorio Alfieri. Por isso os românticos acusavam os classicistas de transformar a

\footnotetext{
289 "La differenza che v'è tra classico e romantico in Inghilterra non è la stessa che s'è stabilita fra noi. (...) II Tempo però che dissipa tutti gli errori dimostrerà che i romantici italiani non furono poi tanto ridicoli allorchè manifestarono il desiderio che la letteratura della loro patria influisse efficacemente al miglioramento morale della nazione; e se dureranno in Italia le denominazioni di classico e romantico, esse non accenneranno più due partiti discordi su questo punto, ma soltanto (come attualmente in Inghilterra) due dottrine letterarie, l'una delle quale cerca d'emulare gli antichi in quella specie di bello, di cui l'attributo principale è il Semplice, e l'altra nel rinvenire un'altra specie di bello, di cui l'attributo principale è il Singolare." Silvio Pellico. "Gertrude of Wyoming, ec. Gertrude di Wyoming. Poema in tre canti di Tomaso Campbell. Terza edizione. Londra, 1810." Num 39 (14/01/1819), p. 154 (nossa tradução)
} 
Itália em uma China, cercada por uma grande muralha intransponível às novas ideias. $^{290}$

Gian Domenico Romagnosi pede aos letrados "leiam os escritos teóricos, e sobretudo as produções da literatura setentrional, e ao fazê-lo se darão conta de que se ali existe algum fragmento de poesia romântica, ninguém se propôs a ser, na verdade, exclusivamente romântico ou exclusivamente clássico no sentido que se dá no momento, de forma abusiva, a estas denominações. Descobrirão, ao contrário, que ali são tratados assuntos e feito uso de similitudes e alusões mitológicas de um modo que os latinos jamais se permitiriam." 291 Os românticos buscavam novos ares para a cultura italiana, em sua visão saturada pelo mofo dos séculos passados e ridiculamente adornada por recursos retóricos de duvidosa origem greco-romana. Era preciso desenvolver uma nova mentalidade artística, livre dos modelos impostos pelas academias. Giovanni Berchet se declara obrigado a "repetir solenemente um conselho que através de cem formas diferentes temos já dado cem vezes no nosso jornal. Ei-lo, e afim de que desta vez ele seja compreendido também por aqueles que se dedicam a tirar o pó nos salões da república das letras, agora em maiúsculas: AO RECOMENDAR A LEITURA DE POESIAS ESTRANGEIRAS NÃO PRETENDEMOS JAMAIS SUGERIR AOS POETAS DA ITÁLIA A SUA IMITAÇÃO. DESEJAMOS APENAS QUE ELAS SIRVAM PARA DILATAR AS FRONTEIRAS DO SEU JUÍZO CRÍTICO." ${ }^{292}$ A partir deste ponto, se existir um modelo é o não seguir modelo algum: o gênio romântico deve impor a sua originalidade e criar novas formas de expressão, desconhecidas pelos artistas que insistem em imitar as obras dos grandes mestres da Antiguidade. E para que tudo isso se torne uma realidade, II Conciliatore clama por uma nova educação para os jovens: "Parai, ó italianos, de manter vossos filhos curvados por oito ou dez anos a aprender a língua latina e o

\footnotetext{
${ }^{290}$ Os românticos diziam que os classicistas desejavam isolar culturalmente a Itália do resto da Europa, fechando suas fronteiras às ideias renovadoras vindas do exterior. Ver Giuseppe Pecchio. "Dialogo tra un Chinese ed un Europeo". Num 12 (11/10/1818), pp 45-46

291 "Leggano gli scritti teoretici, e sopratutto le produzioni della letteratura settentrionale, e di leggerli si accorgeranno che se havvi in essa qualche pezzo di romantica poesia, niuno si è mai avvisato nè per teoria nè per pratica di essere esclusivamente romantico, nè esclusivamente classico nel senso che si dà ora abusivamente a queste denominazioni. Troveranno anzi essersi trattati argomenti, e fatto uso di similitudini e di allusioni mitologiche anche in un modo, che niun latino si sarebbe permesso." Gian Domenico Romagnosi. Op cit, p. 12

292 "(...) ripetere solennemente una dichiarazione che sotto cento forme diverse abbiamo già ricantata le cento volte nel nostro giornale. Eccola; ed affinchè sia intesa anche dagli spazzini della repubblica letteraria, eccola una buona volta in lettere maiuscole: COL RACCOMANDARE LA LETTURA DI POESIE COMUNQUE STRANIERE, NON INTENDIAMO MAI DI SUGGERIRNE AI POETI D'ITALIA L'IMITAZIONE. VOGLIAMO BENSÌ CHE ESSE SERVANO A DILATARE I CONFINI DELLA LORO CRITICA." Grisostomo (Giovanni Berchet). Op cit, p. 400
} 
alfabeto grego - belíssima língua e belíssimo alfabeto sem dúvida, mas não os únicos estudos que abrem o intelecto do Homem. Abandonai os métodos pedantes e vereis que em oito ou dez anos se consegue também aprender as línguas vivas dos nossos irmãos europeus, através de cujo conhecimento se adquirem novas luzes e novos prazeres - novos parâmetros para o Belo e o Verdadeiro." 293

II Conciliatore foi um importante difusor, na Itália, de autores estrangeiros, principalmente ingleses e alemães. Em suas páginas foram resenhados Schiller, Gessner, Byron, Sheridan e outros hoje esquecidos mas cujas obras começavam a ser traduzidas e publicadas, não apenas em Milão como também em outras cidades. Porém esse esforço de integrar a cultura italiana ao fluxo da nova cultura romântica europeia (nem tão nova assim pois a maioria das obras fora escrita a mais de uma década) encontrava uma forte resistência nos círculos classicistas, cujas academias denunciavam a conspurcação das artes nacionais pela invasão das ideias estrangeiras. Por causa dessa postura os românticos passaram a dar a alcunha de "chineses" àqueles críticos refratários ás novas tendências, acusando-os de querer construir uma muralha que separasse a Itália do resto da Europa. É a esses que se dirige Silvio Pellico afirmando "alguns chineses, nascidos entre nós, se enfurecem toda a vez que ouvem falar de literatura estrangeira, persuadidos de que nada existe além daquilo que está contido no lado de cá da grande muralha. (...) Honremos as verdadeiras glórias da nossa pátria, como zelosos cidadãos desta, mas honremos também, como cidadãos de toda a sociedade humana, tudo o que de admirável se produz ou se escreve em qualquer parte do globo." 294 Nessa mesma linha de raciocínio pergunta Giuseppe Nicolini: “Enobrecer a função da Crítica; dilatar a ideia

\footnotetext{
293 "Cessate, o italiani, del tenere i vostri figli curvati per otto o dieci anni a non imparare fuorché la lingua latina e l'alfabeto greco - bellissima lingua e bellissimo alfabeto senza dubbio, ma non i soli studi che aprano l'intelletto dell'uomo. Bandite i metodi pedanteschi, e vedrete che in otto o dieci anni si possono anche imparare le lingue viventi dei nostri fratelli europei, e che colla cognizione d'esse si acquistano nuovi lumi e nuovi piaceri - nuovi oggetti di paragone, e quindi nuovi scoprimenti del Bello e del Vero." Silvio Pellico "Specimen of the British poets, with biographical and critical notices, and an essay on English poetry. By Thomas Campbell. London 1819 - sette volumi in ottavo." Num 112 (26/09/1819), p. 437 (nossa tradução)

294 "Alcuni chinesi, fra noi nati, si sdegnano ogni volta che odono a parlare di letteratura straniera persuasi che nulla v'ha d'ottimo fuorché ciò che è contenato al di qua dalla gran muraglia. (...) $O$ noriamo le vere glorie della nostra patria, come zelanti cittadini di essa; ma onoriamo anche, come cittadini della intiera società umana, tutto ciò che di lodevole si opera o si scrive in qualsivoglia parte del globo." Silvio Pellico. "Philippe II, tragédie de M. J. de Chénier - Theatre de Chénier - Paris, 1818" num 62 (04/04/1819), p. 250 (nossa tradução)
} 
de Belo, ensinando como reconhecê-lo em todos os gêneros e em todos os povos, será isso desprezar a própria nação, a sua própria literatura e suas glórias?" 295

O posicionamento de II Conciliatore em relação à produção literária de outros países europeus pode ser resumido em alguns parágrafos da resenha escrita por Silvio Pellico para a novela $\mathbf{O}$ Corsário, de Lord Byron, que fora recentemente traduzida para a língua italiana. Vejamos a opinião de Pellico:

A glória que se adquire com a produção de excelentes livros originais desaconselha muitos literatos ambiciosos a dedicarem-se às traduções de livros estrangeiros. Todos desejam pavonear-se com o título de autor, não levando em consideração que a pouquíssimos é concedido o dom de escrever coisas de altíssimo nível, e que os medíocres não desfrutam da glória mas do desprezo. É dessa presunção que derivam as invectivas que frequentemente entre nós são lançadas contra as literaturas estrangeiras: "Somos todos gênios criadores, diz a turba de escritorizinhos, nada temos a admirar em parnasos distantes; a introdução na Itália de livros ingleses e alemães nada mais provoca do que a corrupção do Gosto." (...)

Ao tornar conhecida na Itália $\mathbf{O}$ Corsário de Lord Byron, ou qualquer outra composição estrangeira, não se diz aos italianos: eis aqui o que deveis imitar, aqui está um modelo melhor do que aquele que tendes! - Leiam, se diz apenas, uma produção de um gênero entre vós ainda não experimentado; julguem-no; rejeitem-lhe os defeitos, mas admirem-lhe a beleza. Admitam então o quanto um gênero pode ser bom, na medida em que sua beleza seja capaz de superar infinitamente os seus defeitos. Se veneramos Dante apesar de algumas deformidades de seu poema que direito temos de chamar Shakespeare de bárbaro só por que nele nem tudo é perfeito?

Mais uma vez repetimos: não se trata de imitarmos os britânicos e os teutônicos, mas abrindo novos horizontes à Crítica esta torna-se mais profética e menos crédula em relação às fábulas supersticiosas da Pedantaria. Porque afinal, não é das luzes mas das trevas que provêm o Erro e o Mau Gosto - Barbárie não significa muito saber mas muito ignorar - não é com dogmas mas com análises que, no campo das ciências humanas, se chega à descoberta do Verdadeiro. ${ }^{296}$

\footnotetext{
295 "Nobilitare l'ufficio della critica, dilatare l'idea del bello, insegnare a ravvisarlo in tutti i generi e in tutti i popoli, sarà un disamare la propria nazione, la propria letteratura, le proprie glorie?" Giuseppe Nicolini. Op cit, p. 320

296 "La gloria che si acquista col produrre eccelenti libri originali, sconsigli molti ambiziosi letterati dal dedicarsi alle traduzioni di libri esteri. Ognuno vuol pavoneggiarsi del titolo d'autore, e non si considera quanto a pochissimi sia conceduto di scrivere altissime cose; e le mediocri non fruttano gloria ma disprezzo. Da questa presunzione derivano le invettive che spesso fra noi si sono scagliate contro le letterature straniere. Noi siamo tutti geni creatori, dice il volgo degli scrittorelli, non abbiamo nulla da ammirare sovra i parnasi lontani; introducendo in Italia la cognizione de' libri inglesi e tedeschi, non si fa altro che corrompere il gusto." (...)

Facendo conoscere all'talia il Corsaro di lord Byron, o altro qualunque componimento straniero, non si dice agl' italiani: ecco ciò che dovete imitare, ecco un modello migliore di quelli che possedete! - Leggete, si dice loro soltanto, una produzione d'un genere fra voi non tentato ancora; giudicatela, rigettatene i difetti, ma ammiratene le bellezze, ed ammettete come buono il genere, qualora ivi i defetti sieno dalle bellezze infinitamente superati; se veneriamo Dante malgrado alcune
} 
Essas palavras expressam nitidamente a posição dos românticos: eles desejam uma reforma na cultura italiana. O novo rumo proposto não pressupõe uma rejeição da cultura clássica mas a abertura para novas linguagens poéticas de matriz não latina. Isso significava o reconhecimento de que a Itália havia surgido após a queda do Império Romano do Ocidente, e era fruto de uma miscigenação entre os remanescentes dos romanos e os povos germânicos que invadiram a Península ao fim da Antiguidade. A insistência em paradigmas mitológicos de origem grecoromana alienava aqueles que não tinham acesso a essa cultura (morta a muitos séculos junto com o povo que a criara) e tornava a invenção poética uma fantasia delirante sem lastro com a realidade. Como consequência a Literatura perdia sua função social de expressar os sentimentos e as opiniões de sua época, deixando a cultura produzida na Itália um tanto quanto anacrônica em relação à produção cultural europeia. O que podemos observar nas páginas de II Conciliatore é a denúncia veemente desse anacronismo e as propostas para um intercâmbio com as novas tendências expressas pelo Romantismo.

A grande discussão travada entre classicistas e românticos aconteceu em relação à Dramaturgia. A obra dramática é, em sua essência, uma obra incompleta: ela depende da interpretação dos atores, da montagem realizada por um encenador, da iluminação, dos cenários e figurinos, da maquiagem e, o mais importante, da reação de um público. Ou seja, a crítica teatral só pode ser realizada em função de um espetáculo, e não em função de um texto. As qualidades e os defeitos de um dramaturgo só aparecem diante de uma plateia. Isso posto, precisamos entender quais eram as exigências da crítica clássica para que o texto dramático atingisse o seu objetivo: deleitar o público. ${ }^{297}$

deformità del suo poema, qual dritto avremo di chiamar barbaro Shakespear, perché egli pure non è tutto gemme?

Ripetiamolo: non già per renderci imitatori de' britanni nè dei teutoni, ma perchè, aprendo nuovi orizzonti alla critica, si rende questa più veggente e meno credula alle superstiziose fole della pedanteria; perchè insomma, non dai lumi ma dalle tenebre provengono l'Errore e il cattivo Gusto non il molto sapere ma il molto ignorare è barbarie - non coi dogmi ma coll'esame si giunge, in fatto di scienze umane, allo scoprimento del vero."

Silvio Pellico. "Il Corsaro, novella di Lord Byron. Versione in prosa di L. C. - Torino, vedova Pomba e figli, 1819." Num 68 (25/04/1819), p. 273 (nossa tradução)

${ }^{297}$ Ver a esse respeito José Ortega y Gasset. A ideia do Teatro e Marvin Carlson. Teorias do Teatro. 


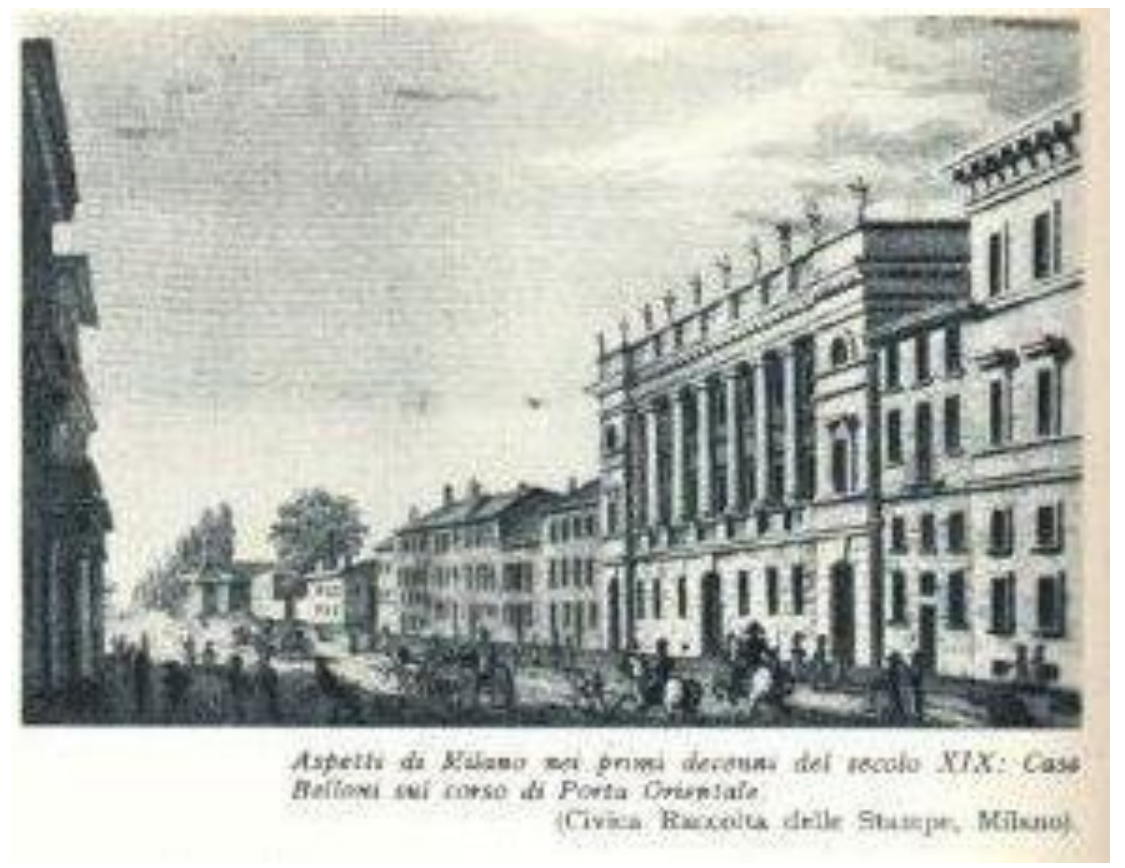

Vista de Milão nas primeiras décadas do século XIX: Casa Belloni na Rua da Porta Oriental (in Cesare Spellanzon. Storia del Risorgimento e dell'unità d'Italia, p. 624).

Giuseppe Antonio Borgese nos ensina que na visão clássica, "como a poesia imita o verdadeiro, um princípio infalível da crítica consistia em observar as relações de conformidade entre a representação e as coisas representadas. A pintura dos caracteres deveria ser fiel, o desenvolvimento da ação manter-se verossímil e a descrição evidente." 298 E como o dramaturgo deveria escrever sua obra para que ela cumprisse essas exigências? Ele teria, obrigatoriamente, de ater-se às três unidades da poética clássica: a unidade de lugar, a unidade de tempo e a unidade de ação. Essas unidades, que a princípio teriam sido extraídas da Poética de Aristóteles pelos estetas italianos da Renascença, foram codificadas pelo francês Nicolas Boileau-Depreaux em seu livro A Arte Poética, de 1674. ${ }^{299}$ A ação da peça deveria se desenvolver em um único lugar, de preferência um aposento; havia uma tolerância para um edifício, por exemplo, todos os personagens estariam em um palácio; em casos extremos a história poderia se passar em uma cidade ou vila. Todos os acontecimentos da peça deveriam transcorrer, impreterivelmente, em vinte quatro horas. Todos os personagens devem estar envolvidos em uma única trama, não aceitando-se histórias paralelas ao enredo central. Não pretendemos neste

\footnotetext{
298 'Poiché la poesia imita il vero, un principio infallibile di critica era nell' osservare le rispondenze tra la rappresentazione e le cose rappresentate. Doveva la pittura dei caratteri esser fedeli, lo svolgimento delle azioni mantenersi verisimile, la descrizione evidente." G. A. Borgese. Op cit, p. 35 ${ }^{299}$ Existe uma tradução, em prosa, desse livro realizada pela Prof. $\stackrel{\text { a }}{\mathrm{Dr}}$. ${ }^{\text {a }}$ Célia Berrettini e publicada pela Editora Perspectiva em 1979.
} 
estudo fazer uma análise das origens e pertinências dessas unidades, o nosso objetivo é situar o leitor no debate, uma vez que a crítica romântica se opôs veementemente às unidades de lugar e de tempo, assim como aos enredos inspirados na mitologia greco-romana.

II Conciliatore desenvolverá, como argumento central de sua crítica, a tese de que o teatro clássico é anacrônico. O público do século XIX não era o mesmo que frequentava os teatros no século XVIII, assim sendo o espetáculo que esse público pedia não podia ser o mesmo que lhe fora oferecido décadas antes: ${ }^{300}$ para um novo público um novo teatro. Giovanni Berchet afirma que, em termos de dramaturgia, não deixa jamais de "recomendar a originalidade e a escolha de argumentos que convêm a nossa presente condição social." 301 Silvio Pellico defende a ideia de que "é Poesia aquilo que inflama e comove; e nos comovem muito mais as recordações modernas do que as bagatelas dos tempos incertos." 302 Pellico, ele mesmo autor de uma tragédia de fundo histórico (Francesca da Rimini) que obtivera grande sucesso de público em Milão no ano de 1814, diz em outro artigo "a mais instrutiva, a mais eficaz, a mais filosófica das tragédias nos parece ser a histórica. E por histórica não pensamos naquela referente a fatos antiquíssimos, mas a que nos fala sobretudo dos nossos avós, das nossas glórias nacionais e dos delitos memoráveis que os corromperam." É interessante notar como Pellico evoca Boileau, o grande mestre da estética classicista, ao destacar o caráter didático do texto teatral: "O vulgo que não dispõe de tempo para ler aprende aqui os gloriosos feitos paternos." Ele prossegue dizendo que os letrados podem aprimorar suas ideias sobre os acontecimentos históricos já que um espetáculo teatral é muito mais vibrante do que a leitura de um livro. ${ }^{303}$ É essa preocupação em dar à obra de arte

\footnotetext{
${ }^{300}$ Esse mesmo argumento público moderno versus dramaturgia ultrapassada será desenvolvido poucos anos mais tarde por Stendhal em Racine e Shakespeare.

301 "Io che non cesso mai dal raccomandare l'originalità, e la scelta d'argomenti adattati alla nostra presente condizione sociale." Grisostomo (Giovanni Berchet). "Sulla Sacontala ossia l'anello fatale, drama indiano di Calidassa." Num 53 (04/03/1819), p. 212 (nossa tradução)

302 "È Poesia ciò che infiamma e commuove; e ci commuovono assai più le ricordanze moderne che non le fanfaluche dei tempi incerti." Silvio Pellico. "Philippe II, tragédie de M. J. Chernier - Theatre de Chernier - Paris, 1818". Num 62 (04/04/1819), p. 249 (nossa tradução)

303 "(...) La più istruttiva, la più efficace, la più filosofica delle tragedie ci sembra essere la storica; e per istorica non intendiamo quella che ci rammenta senza pro alcuni fatti d'antichissimi annali, ma quella che ci parla sovra tutto de' nostri avi, delle nostre glorie nazionali e dei memorabili delitti onde queste furono contaminate. Vera istruzione si è dessa. II volgo che non ha tempo di leggere impara ivi i fasti paterni, e gl'ingegni pensanti essendo dallo spettacolo d'un' azione più fortemente scossi che dalla lettura di un libro, raffinano le loro meditazioni sulle vicende de' mortali, e ne derivano maggior giustezza di critica ed energia di sentimento nella sociale condotta." Silvio Pellico. "Charles IX, ou La
} 
um caráter cívico, didático e moral (compreensível em um momento histórico no qual se buscava assentar as bases do ressurgimento italiano) que aproxima o grupo de II Conciliatore dos classicistas e o afasta dos românticos ingleses e alemães. ${ }^{304}$

Outra vertente da crítica romântica nas páginas de nosso periódico é a que sustenta ser o público um produto de uma época histórica. Dentro dessa visão diferentes momentos da História geram espectadores diferentes, que possuem necessidades estéticas diferentes e por isso exigem dos dramaturgos abordagens diferentes. Essa é a argumentação do "Diálogo sobre as unidades dramáticas de lugar e de tempo", de Ermes Visconti. Lá podemos ler

O gosto teatral dos povos possui quatro épocas distintas. A primeira época é aquela da curiosidade. (...) quando a arte é nova, a novidade tem um quê de beleza, de verossimilhança, de comoção. A segunda época é aquela do interesse; e foi na Europa a época dos dramas romanescos, e de outras composições baseadas no senso comum dos espectadores. Pouco a pouco o gosto refina-se, confronta-se, os doutos se apresentam e dizem: isto não está bom, seria melhor assim. Começam as vaias, os aplausos diminuem. Eis então a terceira época, aquela da civilização teatral. (...) A época da perfeição se verifica quando o público já aprendeu a conhecer até que ponto pode chegar a beleza de uma tragédia, comédia ou qualquer outra coisa, e exige dos poetas que atinjam aquela meta, de forma compatível com o argumento tratado. ${ }^{305}$

Saint-barthélemi, tragédie de Chernier - Theatre de M. J. de Chernier. Paris, 1818." Num 69 (29/04/1819), p. 277 (nossa tradução)

${ }^{304}$ Tratamos desse tema em 4.2 A visão romântica da História.

305 "Il gusto teatrale de' popoli ha quattro epoche. La prima epoca è quella della curiosità. (...) quando l'arte è nuova, la novità tiene luogo di bellezza, di verisimiglianza, di commozione. La seconda epoca é quella dell'interesse: e fu in Europa l'epoca de' drammi romaneschi, e di altre composizioni calcolate sulle idee abituali degli spettatori. A poco a poco si raffina, si confronta, i dotti si fanno innanzi e dicono: questo non va bene, andrebbe meglio così: s'incomincia a fischiare, si applaudisce meno; ecco la terza epoca, quella della civilizzazione teatrale. (...) L'epoca della perfezione si verifica, quando il pubblico ha imparato a conoscere fino a qual grado può andare la bellezza d'una tragedia, commedia o altro; ed esige dai poeti che vadano fino a quel grado, compatibilmente coll'argomento che trattano." Ermes Visconti. "Dialogo sulle unità drammatiche di luogo e di tempo". Num 43 (28/01/1819), p. 169 (nossa tradução) 


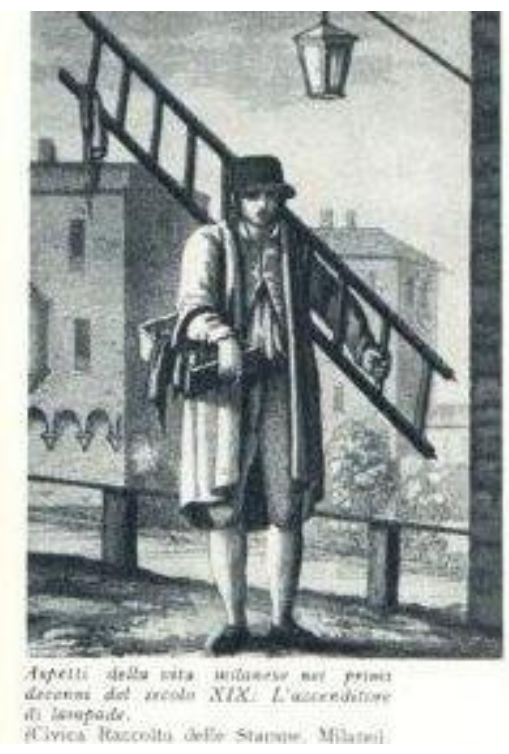

Cenas da vida milanesa nas primeiras décadas do século XIX: o acendedor de lâmpadas

(in Cesare Spellanzon. Storia del Risorgimento e dell'unità d'Italia, p.619)

Essa noção de que existem vários estágios no desenvolvimento da Cultura e das Artes é também compartilhada por Giovanni Berchet. Segundo ele, "a poesia dramática não é cultivada pelos povos senão quando suas civilizações já estão bastante avançadas. Pensemos em todas as histórias dos povos letrados e veremos primeiramente os poetas líricos, épicos ou didascálicos, e somente depois de muito tempo os dramáticos." 306 Tudo isso ia de encontro ao eixo central da crítica classicista, que pregava a imitação dos grandes mestres da Antiguidade através da obediência às unidades aristotélicas. Giuseppe Montani, ${ }^{307}$ um dos fomentadores do Classicismo, respondeu aos românticos "Madame de Staël, se bem recordo, tratando a questão dos dois sistemas teatrais naquele seu livro sobre literatura tão citado, em sua época, por livros e artigos em periódicos (entre os quais podemos enumerar o diálogo de Ermes Visconti sobre as unidades, elogiado pelo nosso Manzoni, traduzido por Fauriel, imitado por Stendhal e acolhido às gargalhadas por inúmeros infelizes quando apareceu em II Conciliatore) distinguiu muito bem as leis do gosto imutável das leis dramáticas de convenção." ${ }^{308}$ Mesmo

\footnotetext{
306 'La poesia drammatica non è coltivata ne' popoli se non quando la civilizzazione loro è inoltrata assai. Ponete mente a tutte le storie dei popoli letterati e vedrete prima poeti lirici, epici o didascalici, poi dopo molto tempo drammatici." Grisostomo (Giovanni Berchet). Op cit, p. 210.

${ }_{307}$ Giuseppe Montani (Cremona 1789 - Florença 19/02/1833) colaborou com artigos variados sobre literatura, moral, arte e política na revista Antologia.

308 "Madama di Staël, se ben mi ricordo, trattando la quistione dei due sistemi teatrali in quel suo libro della letteratura che a suo tempo sarà inteso come più altri libri e frammenti riguardevoli di scritti periodici (fra i quali annoveriamo il dialogo d' Ermes Visconti sulle unità, citato con tanta lode dal nostro Manzoni, tradotto dal Fauriel, imitato da Stendhal, e accolto con le risa da tante povere
} 
escrito em 1825 (seis anos após o fim de nosso jornal) o ensaio de Montani ainda sustenta a ideia de que o Bom Gosto é imune à História e que a grande obra é aquela que permanece através dos tempos. Essa insistência na construção de uma beleza estética cristalizada, evocação das criações da Antiguidade, tal como fora concebido trezentos anos antes pelos estetas da Renascença é a marca do Classicismo italiano. Podemos observar isso nesta passagem escrita por Pietro Molossi em 1818:

Quase todos os fautores do Romantismo concordam em asseverar: que os fundamentos da verdadeira poesia devem ser derivados unicamente da índole dos tempos, dos costumes, da civilidade, da forma de governo, do clima, da religião das respectivas nações; que todas as teorias dos clássicos e principalmente as regras de unidade de ação, de tempo e de lugar não pertencem à escola romântica; dessa forma o estilo romântico não se apegará aos enredos de invenção, às similitudes, às alegorias inspiradas pela história antiga e especialmente pela Mitologia; como também não será do estilo romântico o seguir escrupulosamente as regras de ordem, simetria, proporção e clareza a que os estetas chamam de economia da composição.

E por que não deve a dramaturgia romântica prender-se a regras de composição e a enredos de inspiração mitológica? De acordo com Giovan Battista de Cristoforis, "tragédias baseadas na Mitologia e em acontecimentos gregos revelam-se a nós de pouquíssimo interesse, uma vez que se opõe frontalmente à nossa presente fé religiosa." 310 Como o Cristianismo prega a consolação e o perdão não é aceitável, para um público cristão, histórias de deuses cruéis, ciumentos e vingativos. Nem tampouco o destino do Homem pode ser traçado por forças sobrenaturais em situações que negam o livre arbítrio proclamado nos Evangelhos. Além disso, como salienta Giuseppe Nicolini, o uso da Mitologia e da

creature quando comparve nel Conciliatore), distinse molto saviamente le leggi del gusto immutabile dalle leggi drammatiche di pura convenzione." Giuseppe Montani. "Sulle tragedie e altre opere di A.Manzoni (Antologia, agosto 1825)." In Discussioni e Polemiche sul Romanticismo (1816-1826), volume 2, pp 265-266 (nossa tradução)

309 "Quasi tutti i fautori del Romanticismo convengono nell'asserire: che i fondamenti della vera poesia devonsi unicamente desumere dall' indole dei tempi, dai costumi, dalla civiltà, dalla forma di governo, dal clima, dalla religione delle rispettive nazioni; che tutte le teorie de' classici, e singolarmente le regole di unità d'azione, di tempo e di luogo, non appartengono alla scuola romantica; che quindi non sarà più dello stile romantico l'attenersi ai soggetti d'invenzione, alle similitudini, alle allegorie prese dalla storia antica, e specialmente dalla Mitologia; come non sarà dello stile romantico il seguire scrupulosamente le regole di ordine, simmetria, proporzione, chiarezza che dai precettisti vengono chiamate l'economia della composizione." Pietro Molossi. "Del Romanticismo (Accattabrighe, dicembre 1818)" in Discussioni e Polemiche sul Romanticismo (1816-1826), volume 1, pp 475-476 (nossa tradução)

310 “(...) Tragedie fondate sulla Mitologia e sull'irresistibile fato de' Greci riescono per noi di pochissimo interesse, siccome quelle che perfettamente si opongono alla presente nostra fede religiosa (...)."Giovan Battista de Cristoforis. "Bibli tragedia di Antonio Gasparinetti - Mileto tragedia di Stanislao Marchisio." num 84 (20/06/1819), p. 338 (nossa tradução) 
história antiga nos enredos dramáticos introduzia na cultura italiana elementos estranhos aos costumes peninsulares, uma vez que "se como estrangeiros às ideias e sentimentos nacionais não convêm à Itália o idealismo, a metafísica e a melancolia do norte da Europa, pela mesma razão não lhe convêm, em sua maior parte, a leviandade e a sensualidade dos antigos, e sobretudo o materialismo de sua mitologia." 311 Por todas essas razões, como salienta Silvio Pellico, "as representações gregas e latinas haviam caído em desuso com a queda da antiga cultura" e na Europa medieval desenvolvera-se, embora de forma incipiente, um teatro inspirado na vida dos santos e em passagens dos Evangelhos, "de índole similar à renascente civilização". Foi no final do Quatrocentos, nas palavras de Pellico, que "se descobriram os tesouros do teatro antigo e sonhou-se tomá-los por modelos, muito embora eles não fossem mais apropriados aos nossos costumes." 312 Ou seja, para os românticos de II Conciliatore o teatro clássico inspirado nas tragédias áticas já era anacrônico em sua origem, uma vez que ia de encontro à ideologia cristã da civilização europeia, construída na Idade Média.

Se a Mitologia devia ser banida dos enredos dramáticos o que dizer das três unidades? Nem mesmo a autoridade de Aristóteles era suficiente para sustentá-las. $\mathrm{Na}$ opinião de Giovan Battista de Cristoforis, "se as produções de Ésquilo, de Sófocles e de Eurípides são monumentos de uma genialidade admirável, e se a poética de Aristóteles é tudo menos algo a ser desprezado, daí não deriva o fato que se deve seguir servilmente a arte dos antigos no teatro moderno, e que tenhamos de acatar como um oráculo todas as sentenças do velho filósofo." O autor indaga por que enquanto a lógica, a metafísica e os estudos sobre as ciências da natureza do Estagirita são contestados pelas novas descobertas do saber humano "muitos literatos da nossa Península acreditam ser um sacrilégio a menor inobservância das

\footnotetext{
311 “(...) se come stranieri alla serie delle idee e de' sentimenti nazionali non convengono all'Italia l'idealismo, la metafisica e la melanconia del nord, per la ragione medesima non le convengono maggiormente la leggerezza, la sensualità, degli antichi, e sopra tutto il materialismo della loro mitologia." Giuseppe Nicolini. "Sulla poesia tragica, e occasionalmente sul Romanticismo - lettera di un buon critico e cattivo poeta ad un buon poeta e cativo critico." num 79 (03/06/1819), p 319 (nossa tradução)

312 "Le rappresentazioni greche e latine erano cadute affatto in disuso col cadere dell'antica coltura, e di loro più nulla si seppe fintanto che, avendo già l'Europa nuovi spettacoli scenici, informi sì, ma di indole analoga alla rinascente civiltà, si scopersero i tesori del teatro antico e si sognò di chiamarli modelli, benché più non fossero adattati ai nostri costumi." Silvio Pellico. "Vera idea della tragedia di Vittorio Alfieri, ossia la dissertazione critica dell'avvocato Giovanni Carmagnani confutata dall'avv. Gaetano Marrè, professore di diritto commerciale nella R. Università di Genova - vol 2, Genova 1817." num 8 (27/09/1818) p. 29 (nossa tradução)
} 
suas regras dramáticas?" 313 Hoje em dia, após os estudos estéticos de Goethe e de Hegel, é muito difícil encontrar alguém que afirme serem as unidades de tempo e de lugar uma exigência de Aristóteles colocada em seu livro A Poética ${ }^{314}$. A bem da verdade a discussão não era com o filósofo grego, mas com seus seguidores italianos. Giuseppe Nicolini reclama que "as poéticas nada mais são do que tratados de imitação" que aprisionam a criatividade dos poetas e impedem o desenvolvimento da arte dramática, e que as resenhas críticas transformaram-se em "tribunais de inquisição e intolerância” onde apenas aqueles que seguem as regras clássicas de composição são absolvidos. ${ }^{315}$ Para os românticos isso era uma aberração uma vez que a época moderna era totalmente diferente da Antiguidade, quando não fazia sentido a discussão dessas exigências. Para Silvio Pellico, o incrível era que as tragédias italianas nada tinham a ver com as produções gregas e romanas, muito embora procurassem imitá-las da melhor forma possível. Mas os classicistas não possuíam olhos para detectar as diferenças: "Que importa que a tragédia daqui seja toda ação enquanto a de lá era, na sua maior parte, um coro? Que importa que aqui declame-se enquanto lá cantava-se? Foi decidido pelas academias que são coisas idênticas, e por isso não existe mais dúvida." ${ }^{116} \mathrm{O}$ que II Conciliatore procurava mostrar era que o teatro classicista italiano ao seguir as regras supostamente ditadas pelos antigos nem de longe se equiparava às obras que desejava imitar. $E$ ia além quando dizia que mesmo jovens talentosos não conseguiam alçar voos por que eram tolhidos em sua imaginação criadora pelos críticos intolerantes encastelados nas academias de letras.

\footnotetext{
313 "Ma se le produzioni d'Eschilo, di Sofocle e di Euripide sono monumenti di ammirabile genio, e se la poetica d'Aristotile è tutto altro che una cosa spregevole, non ne deriva di conseguenza che si debba servilmente seguire l'arte degli antichi nel moderno teatro, e che si abbiano a riguardare come oracoli tutte le sentenze dell'antico precettista. Come avviene egli mai che mentre i libri del filosofo di Stagira sulla Logica, sulla Metafisica e sulle Scienze Naturali ottengono soltanto quel credito che possono meritare cose dettate nella giovinezza del sapere umano, e vi si approva soltanto ciò che evvi di vero, rifutandosi senza scrupolo e senza cerimonie i moltiplici errori onde que' libri ridondano; come avviene, dico, che per lo contrario molti letterati della nostra penisola credano sacrilega qualunque più lieve inosservanza delle due regole drammatiche?" Giovan Battista de Cristoforis. Op cit, p. 337

${ }^{314}$ Sobre a contestação da autoria de Aristóteles sobre as três unidades ver Goethe. Memórias: Poesia e Verdade e Hegel. Curso de Estética: O Sistema das Artes. Acredita-se hoje que essas unidades foram presumidas por alguns estetas da Renascença italiana. De acordo com Hegel, Aristóteles pregava apenas a unidade de ação.

${ }^{315}$ Giuseppe Nicolini. Op cit, p. 320

316 "Che importa che qui la tragedia sia tutta azione, mentre là era per la massima parte un coro? Che importa che qua si declami, mentre là si cantava? É deciso dalle accademie che la cosa è identica; dunque non v'ha più dubbio." Silvio Pellico. Op cit, p. 30
} 
Os classicistas defendiam suas posições dizendo que os românticos desprezavam o patrimônio cultural herdado da Grécia e de Roma, cujo legítimo depositário era a Itália. Acusavam os adversários de introduzir conceitos inaplicáveis à realidade das artes italianas e desenvolverem um sistema de crítica que não possuía um rigor teórico e metodológico plausível. Carlo Giuseppe Londonio, ${ }^{317}$ em 1818, observava:

E por que, exclamam os românticos, deverá o mundo estar eternamente sob a influência dos escritores de poéticas? E quem são esses que desejam ser os mestres de todo o gênero humano? (...) Esses preceitos e essas poéticas, os quais vocês andam apedrejando, não são um receituário de aforismos ditados por capricho ou por uma magistral pedantaria. Deemse ao trabalho de confrontá-los com as obras-primas da Antiguidade e vocês verão que eles nada mais são do que a teoria dos princípios postos em prática naquelas que vocês mesmos chamam de produções do Gênio; princípios apoiados nas leis invariáveis do Bom Senso e da Verossimilhança; princípios consagrados pelo sufrágio unânime de todas as mais cultas nações, desde os belos tempos da Grécia aos nossos dias. ${ }^{318}$

Importante notar nessa passagem as duas noções conflitantes sobre a concepção da História: para os românticos a história humana é uma sucessão de fases, cada uma das quais possui uma cultura apropriada; para os classicistas a História é um contínuo aprimoramento de conceitos, que são passados de geração a geração como um legado a ser preservado. Por isso uma vez atingido um estágio considerado ótimo nada mais se pode fazer a não ser imitar de forma a mais fidedigna possível o modelo de perfeição. Como o teatro trágico ateniense atingiu esse patamar, toda a produção dramática deve imitá-lo para ser considerada de alta qualidade. Para isso existem regras precisas e o papel do crítico é aferir se elas foram seguidas de maneira a se obter a excelência desejada. Paride Zaiotti defende as unidades de tempo e de lugar seguindo essa concepção:

O olho também participa das coisas dramáticas e ele é potentíssimo em criar ou destruir a ilusão do intelecto ou do sentimento. Nós não buscamos o Verdadeiro, mas o Verossímil; um ator que no primeiro ato é jovem e morre velho no quinto não conseguirá, de forma plausível, iludir o

\footnotetext{
${ }^{317}$ Carlo Giuseppe Londonio (Milão 01/10/1780 - 10/08/1845) traduziu para o italiano o Laocoonte, de Lessing, em 1833. Criticava no Romantismo apenas o que considerava exageros. Foi inimigo declarado de Ludovico di Breme, um dos principais colabores/fundadores de II Conciliatore.

318 " $E$ che, vanno esclamando i romantici, dovrà dunque il mondo stare eternamente sotto la sfera degli scrittori di poetiche? E chi sono costoro che vogliano far da maestri a tutto il genere umano? (...) Questi precetti e queste poetiche, contro chi vi andate scagliando non sono un ricettario di aforismi dettati dal capriccio e da una magistrale pedanteria. Datevi la fatica di confrontarle coi capi d'opera dell'antichità, e vedrete che esse non sono se non la teoria dei princípi messi in pratica in quelle da voi chiamate spontanee produzioni del genio; princípi consacrati dal suffragio concorde di tutte le più colte nazioni, dai bei tempi della Grecia fino ai nostri dì." Carlo Giuseppe Londonio. "Appendice ai cenni critici sulla poesia romantica. (Milano 1818)" in Discussioni e Polemiche sul Romanticismo (18161826), volume 1, p. 322 (nossa tradução)
} 
espectador, o qual pode muito bem persuadir-se que aquelas duas horas são vinte e quatro por que nada existe que o advirta desse engano. Mas se em uma mesma tragédia ele deve correr do Egito à Sicília, da Sicília a Roma, de Roma ao Egito, do Egito à corte da Itália e depois na Assíria, e de lá novamente a Roma e ao Egito, e do Egito a Atenas e ainda a Roma, e depois a Azio e em seguida ao Egito e assim por diante, assiste-se aos acontecimentos de vários anos condensarem-se em duas horas, a ilusão desaparece e sem ilusão o coração não se aquece nem a mente se eleva. ${ }^{319}$

A função das unidades de lugar e de tempo era tornar o enredo verossímil de forma que o espectador pudesse acreditar na ação que se desenrolava diante dos seus olhos. Se os acontecimentos durassem mais do que vinte e quatro horas e ocorressem em mais de um lugar o público não daria crédito ao que assistia e não se envolveria emocionalmente com o espetáculo. Pietro Molossi diz que os românticos atribuem "às regras aquilo que depende de um princípio totalmente diferente. O clima, a religião, os costumes, o fanatismo e a superstição dos povos é que são as circunstâncias que devem ser examinadas nas várias modificações do gênio e da inspiração poética." Notamos nessa passagem o reconhecimento de que a cultura dos povos é um conjunto de condições variáveis e não uma reunião de conceitos que são passados de uma geração a outra. Prossegue o crítico afirmando "as regras (falo daquelas que não proveem da pedantaria e do preconceito), se não fazem bem, igualmente não produzem nenhum mal. Mas nós possuímos exemplos e argumentos muito convincentes de que as regras, ao contrário de serem danosas, são, isso sim, úteis e necessárias. E não se deve argumentar, uma vez que autores de pouco juízo escrevem tragédias ruins usando as regras, que elas são arbitrárias e nocivas. (É isso que pretendem os românticos de II Conciliatore)." 320 Podemos

\footnotetext{
319 "Nelle cose drammatiche, prende parte anche l'occhio, ed è potentissimo a creare o distruggere l'illusione dell'inteletto e del cuore. Noi non cerchiamo il vero, ma il verisimile; un attore che nel primo atto è fanciullo e muore canuto nel quinto, non è possibile che giunga ad illudere lo spettatore, il quale può ben giugnere a persuadersi che quelle due ore sono ventiquattro, perché non v'é cosa che lo renda avvertito dell'inganno. Ma se in una stessa tragedia dèe correre dall' Egitto in Sicilia, dalla Sicilia a Roma, da Roma in Egitto, dall'Egitto alla corte d'Italia e poi in Assiria, e di là nuovamente a Roma e in Egitto, e dall"Egitto in Atene, e quindi a Roma, e poi ad Azio e poi in Egitto e così via; se scorge gli avvenimenti di più anni condensarsi in due ore, l'illusione sparisce, e senza illusione nè il cuore si riscalda, nè la mente s'innalza." Paride Zaiotti. Op cit, p. 25. O crítico muito provavelmente se refere à tragédia Antonio e Cleópatra, de William Shakespeare.

320 "Voi attribuite alle regole quello che non dipende che da tutt'altro principio. II clima, la religione, i costumi, il fanatismo, la superstizione de' popoli sono esse le circostanze che devonsi esaminare nelle varie modificazioni del genio e dell'ispirazione poetica. Le regole (parlo di quelle che non vengano dalla pedanteria e dal pregiudizio), si non vi fanno niente di bene, non vi fanno egualmente niente di male. Ma noi abbiamo degli esempi e degli argomenti convincentissimi, che le regole, piuttosto che esser danose, sono anzi utili e necessarie. E non si deve mai argomentare dal poco giudizio degli autori nel condur male tragedie colle regole, per venir quindi a conchiudere che quelle regole sieno
} 
achar as respostas a essas ponderações em Giuseppe Nicolini, que defende a liberdade criativa do gênio, já que "a independência das unidades de tempo e de lugar, resultado dos modernos debates literários, nos quais o sistema dramático ocupa uma parte considerável, abre na Itália aos jovens talentos uma nova estrada a seguir, um caminho livre dos obstáculos colocados por aquela escola que escravizou o gênio de Alfieri, deixando um campo aberto para um gênero de beleza a que ele não pôde aspirar." 321 Ou seja, a questão é mais ampla, pois não se trata de censurar o uso das regras de composição por talentos medíocres, mas de apontar as limitações que seu uso impõe aos grandes da dramaturgia. O que os românticos buscavam não eram novas regras que aperfeiçoassem a verossimilhança e a ilusão nos espetáculos teatrais, eles queriam uma nova noção de verossimilhança e de ilusão. Eles queriam não só um novo teatro e uma nova cultura, mas uma nova época e um novo mundo.

O novo paradigma crítico proposto pela cultura romântica era essencial para colocar a Itália na modernidade europeia. A Revolução Industrial, no campo econômico, e a Revolução Francesa, no campo sócio-político, haviam transformado o Ocidente. O alcance dessas transformações diferia entre as diversas nações mas a marcha das mudanças era contínua, apesar dos esforços da Santa Aliança. Podemos dizer, em relação à Península, que o Velho morrera, mas o Novo ainda não nascera. É nesse cenário contraditório, onde as antigas ideias perdem sustentação e as novas concepções ainda procuram apoio, que II Conciliatore, porta-voz do novo sistema, se coloca. Por isso existem radicalizações, concessões, avanços e recuos em um debate que se iniciava nesse período (1815-1821) e que seria vencido pelos românticos muitos anos depois do desaparecimento de nosso periódico.

arbitrarie e nocevoli. (Questo è appunto quello che pretendono i romantici del Conciliatore)". Pietro Molossi. "Sulle unità drammatiche di luogo e di tempo. (Accattabriche, gennaio-febbraio 1819)" in Discussioni e Polemiche sul Romanticismo (1816-1826), volume 2, p. 48 (nossa tradução)

321 'L'independenza dalle unità di tempo e di luogo, risultato de' moderni dibattimenti letterari nei quali ha pur tanta parte il sistema drammatico, apre innoltre in Italia ai giovani ingegni una strada novella a meritare, che sgombra dagli inciampi, di quella scuola a cui volle Alfieri rendere schiavo il suo genio, apre libero il campo ad un genere di bellezze alle quali non poteva egli necessariamente aspirare." Giuseppe Nicolini. Op cit, p. 319 
Silvio Pellico resume as ideias do grupo de II Conciliatore quando diz que as "regras em qualquer arte são sentidas e achadas pela força do Intelecto e não cegamente recebidas por Tradição." Por isso o papel do crítico romântico é diferente daquele desempenhado pelo crítico classicista. O crítico romântico não julga o uso das regras, mas busca orientar o público na descoberta do belo criado pelo artista. A beleza clássica é fruto da imitação dos modelos consagrados pela Tradição; a beleza romântica nasce da originalidade de quem cria a obra de arte. Segundo Pellico, "houve um tempo em que não se examinava no literato nada além das palavras" mas hoje para que se possa apreciar o trabalho de um grande artista é necessário "atentar para as circunstâncias que o educaram, aos motivos que o fizeram adotar ou rejeitar uma doutrina e sobretudo observar os seus dotes mentais." 322 Tudo isso se explica quando percebemos que no Classicismo a obra é o artista e no Romantismo o artista é a obra. E quando o artista se projeta na obra esta passa a ser um testemunho do tempo e do local onde ela foi criada. Esse é um ponto importante observado por Pietro Borsieri, que afirmou "quando uma obra teatral está inteirada tanto nos seus detalhes de execução quanto na totalidade de sua concepção do espírito dos tempos e da nação a qual pertence originam-se duas grandes vantagens: ela influi potentemente sobre aquela nação e sobre aqueles tempos; e deixa para os filósofos e para os historiadores do futuro um solene e inalterável monumento para seu reconhecimento e juízo." ${ }^{323}$ Agindo dessa maneira o artista voltaria a desempenhar, nas sociedades modernas, o papel que tivera nas sociedades antigas, quando era reverenciado pelos povos como o arauto de suas paixões, glórias e vicissitudes.

\footnotetext{
322 "Vi fu un tempo in cui non si esaminavano nel letterato se non le parole. Or per apprezzare secondo il giusto valore anche gli uomini insigni; per sapere di qual loro precetto od esempio si debbano cercare con riverenza le cagioni ovvero soriderne; per osare in qualche parte onorarli quasi d'adorazione $o$ in qualche parte guardarli con non curanza, è comune sentimento che bisogni porre attenzione alle vicende che li educarono, ai motivi che loro fecero adottare o rigettare una dottrina, sovratutto a parecchie delle loro doti mentali." Silvio Pellico. "Maria Stuarda. Tragedia di Schiller, recata per prima volta dal tedesco in italiano da Pompeo Ferrario - Milano 1819." Num 89 (08/07/1819), p. 362 (nossa tradução)

323 'Quando un'opera teatrale sia informata tanto ne' particolari dell'esecuzione che nel tutto insieme del concepimento dallo spirito de' tempi e della nazioni cui appartiene, due grandi vantaggi se ne derivano. Si influisce potentemente su quella nazione e su que' tempi; e si lascia ai filosofi ed agli storici futuri un solenne e non alterabile monumento per ben riconoscerli e giudicarli." Pietro Borsieri. "I Rivali. Commedia di Riccardo Brinsley Sheridan - Tradotta da Michele Leoni - Firenze 1819." Num 96 (01/08/1819), p. 387 (nossa tradução)
} 
$\mathrm{Na}$ medida em que a arte romântica rejeitava os modelos impostos pela tradição clássica na tentativa de representar o novo mundo que surgia após a Revolução Industrial e a Revolução Francesa a tarefa que se impunha aos críticos era igualmente desafiadora: encontrar na obra a sua razão de ser, uma vez que o belo romântico provinha da originalidade do artista e não das regras estéticas difundidas pelas poéticas.

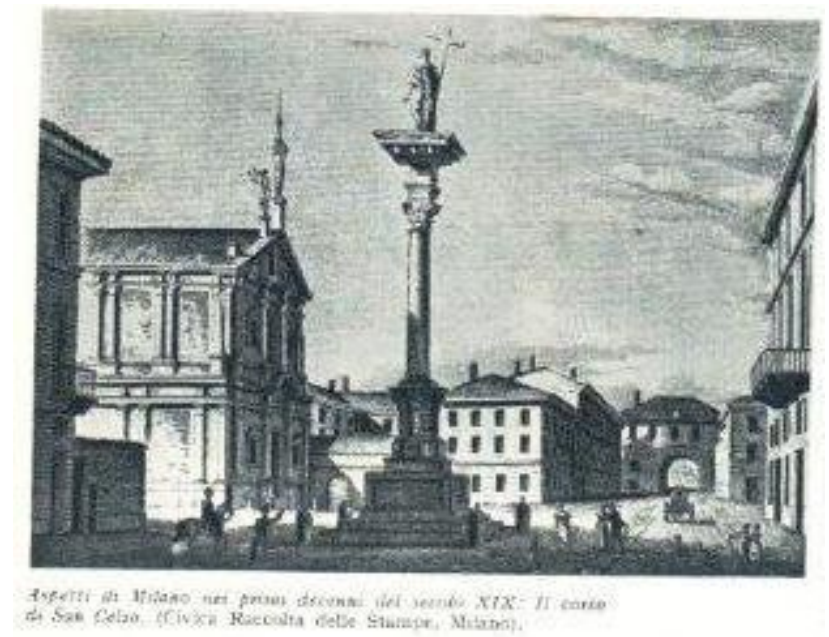

Vista de Milão nas primeiras décadas do século XIX: Rua de São Celso (in Cesare Spellanzon. Storia del Risorgimento e dell'unità d'Italia, p.622)

A introdução das ideias românticas na Itália era limitada por uma contradição intrínseca. Tal como elaboradas na Inglaterra e desenvolvidas na Alemanha essas concepções estéticas procuravam rejeitar a mitologia greco-romana, da mesma forma que os enredos baseados na história antiga, e valorizar a origem medieval da Europa cristã. Buscava-se inspiração nas crônicas da Idade Média, nas canções de gesta e nas tradições populares de cada país europeu, enaltecendo-se o "Espírito do Povo" (volksgeist). Em suma, os românticos desejavam substituir a universalidade clássica pela cor local e trocar o uso da Mitologia pelo uso da História. Porém a história italiana remetia ao Império Romano e a maioria dos monumentos legados pela Antiguidade estava em solo peninsular. Além disso a estética clássica fora gerada na Renascença, era um produto originário da Itália, muito embora tenha encontrado sua melhor formulação na França. Isso dava aos classicistas um sólido argumento: os italianos eram os depositários da herança dos antigos e sua cultura representava a continuidade de uma tradição milenar cuja grandeza não fora conspurcada pelos séculos. 
Nas páginas de II Conciliatore será desenvolvida uma argumentação baseada em uma nova concepção histórica. Primeiramente os italianos modernos não são descendentes dos romanos, mas dos povos germânicos que ocuparam a Península após a queda do Império Romano e miscigenaram-se com os habitantes da terra. Essas populações foram evangelizadas no início da Idade Média e criaram toda uma cultura própria mesclando crenças pagãs ao culto católico. Não existe, portanto, nenhuma tradição greco-romana a ser preservada, já que quem insiste em sua preservação são os doutos das academias e não o povo das cidades e dos campos.

Os românticos italianos reconhecem a grandeza e a beleza das obras de arte dos antigos, mas sustentam que elas são produto de uma época histórica específica que não pode ser reproduzida. Esses trabalhos são belos por que expressam o espírito de um povo, a visão de um tempo passado e para imitá-los é necessário que o artista moderno faça como o artista antigo: fale das coisas e das pessoas que the são próximas, eternize o seu mundo e o modo de vida do seu povo.

Ao denunciar 0 anacronismo em que está mergulhada a produção cultural italiana II Conciliatore faz um esforço para inserir a Itália no fluxo da cultura romântica europeia. Nas páginas de nosso periódico são resenhadas obras alemãs, inglesas, espanholas, francesas muitas das quais não haviam sido traduzidas para o italiano, ou o eram pela primeira vez. Os articulistas insistem em que é necessário conhecer os escritos estrangeiros e acusam os classicistas que se recusam a aprender outras línguas além do latim e do grego clássico de alijar de sua produção artística todos aqueles que não compartilham do conhecimento de tais línguas mortas.

A busca pela contemporaneidade europeia efetuada por II Conciliatore colocava a dramaturgia na linha de frente do acirrado debate travado entre românticos e classicistas. A natureza do Teatro, sua peculiar característica a ser uma arte efêmera, que se realiza diante de um público diferente a cada representação proporciona a oportunidade de comprovar o anacronismo da cultura clássica. Argumentavam os românticos que o público moderno era diferente do público antigo, possuía outra religiosidade e suas instituições sociais eram construídas segundo uma visão de mundo que nada tinha em comum com a Antiguidade e por isso tragédias com inspiração mitológica ou dramatizações de episódios da história antiga não satisfaziam o gosto dos espectadores. Respondiam 
os classicistas que o Bom Gosto e o Belo emanados pelas obras antigas eram insuperáveis e eternos, e além disso as ações dos heróis e dos grandes homens que fizeram a glória dos tempos pretéritos continuavam a ser exemplos de conduta para os cidadãos modernos.

Mas a firme rejeição às unidades dramáticas de lugar e de tempo indicava muito mais do que uma simples discussão teórica. Os membros do grupo de II Conciliatore queriam um novo paradigma: a substituição da Mitologia pela História, o reconhecimento das origens europeias e cristãs da cultura italiana, a valorização da língua nacional como língua culta e a troca da imitação pela originalidade como parâmetro crítico. Para eles eram passados os tempos das tragédias sobre deuses e heróis, os italianos não eram descendentes diretos dos antigos romanos, o latim não podia mais ser a língua culta usada pelos doutos na Itália e as poéticas eram manuais de uma estética ultrapassada pela modernidade. Em resumo, o Classicismo era o Passado e o Romantismo era o Futuro. 
Num. 1 ,

\title{
IL CONCILIATORE
}

\author{
F O G L I O
}

\author{
SCIENTIFICO-LETTERARIO.
}

Os Lusiadas. Poema epico de Luis de Camoens, nova ediçaó, correcta e dada a luz por Dom Joze Maria de Souza Betello - (Un volume in foglio, Parigi, dai tipi di Firmin Didot, 1817$.

$\mathrm{U}_{\mathrm{N}}$ signore portoghese, distinto non meno per la vastità delle sue cognizioni e l'altezza del suo carattere, che per la nascita, dopo aver corso con onore l' aringo diplomatico e rappresentato il suo sovrano presso le corti di Copenhagen, di Londra e di Parigi, ha ora consacrato parecchi anni d'occupazione e una parte ragguardevole delle sue ricchezze ad innalzare un monumento al poeta, a cui i suoi compatrioti riferiscono tutta la loro gloria nazionale. Dopo aver terminato, mediante assidue cure, un' edizione dell' epopea del Camoens, la quale si può considerare come la più magnifica opera che l' arte tipografica abbia mai prodotta, ei l' ha inviata in dono a tutte le pubbliche biblioteche d'Europa, a tutte quelle del Brasile e dell'America, e sino alle estremità delle Indie e della China. $\mathrm{Ha}$ voluto che in ciar scuno di quegli emporj delle arti e delle lettere, il poema conservatore della gloria portoghese fosse riguardato quasi un tesoro che tanto più gelosamente si custodirebbe, non potendosi surrogargliene un simile; perciò non ha consentito che pur un esemplare di questa edizione venisse posto in commercio. Si può ottenere dalla sua generosità, ma non si può comprare.

Il Camoens, dopo aver languito nella miseria, morì in uno spedale; nè con una pietra fu segnato, nel pubblico cimitero, il luogo della sua sepoltura; e il più grand' uomo che abbia prodotto il Portogallo non ricevette una testimonianza di gratitudine da quella patria che egli avea coperta di gloria. Il sig. di Souza volle riparare quella grande ingiustizia nazionale con un atto del più pio entusiasmo; in nome della sua patria, quantunque col suo danaro partico- caduti i suoi predecessori, ed ha appoggiato sovra sutentiche prove il racconto interessantissimo delle strane avventure di quel guerriero poeta, di cui le disgrazie agguagliarono la gloria.

Dopo quei lavori preparatorj, il sig. di Souza si rivolse a Firmin Didot, il più distinto de' tipografi francesi; e questi, come il nostro Bodoni, ha saputo congiugnere alla parte meccanica del suo lavoro tutto il gusto dell' artista e tutte le cognizioni del letterato. Ha fuso per i Lusiadi un nuovo carattere, il più perfetto che sia uscito delle sue officine; la magnificenza della carta, l' equaglianza dell' inchiostro, la nitidezza ammirabile della stampa, sono state proporzionate alla bellezza del soggetto, e l'opera è stata riveduta sulle prove con una diligenza sì scrupolosa che finora non vi si è potuto scoprire un fallo.

Gérard, il primo pittore della scuola francese, ha assunto di dirigere le incisioni che in numero di dodici ornano quella edizione; sono degne per la loro bellezza del nome celebre che portano. Staccate incisioni possono venir loro paragonate, ma niun libro ancora era stato adorno di quadri sì egregi.

Noi quindi ci crediamo assai meno in dovere di chiamare l'attenzione del pubblico sovra un poema da lungo tempo celebre, ed al quale il nostro Tasso non isdegnò $d$ ' andar debitore di molte bellezze, che sovra un atto luminoso di generosità e di patriotismo. Questo atto ci desta riverenza non unicamente per colui che da se solo l'ha adempiuto, ma anche per una patria che ispira sentimenti sì caldi, per una nazione in cui v' è, ora chi s' accorge quanto ella rimanga onorata nell' onorare i suoi grandi uomini, per una nazione che non disgiugne le rimembranze della sua gloria poetica, della sua gloria militare e della sua libertà, e che piange intenerita ripetendo i canti dell'autore dei Lusiadi, perchè ella risente in essi il rimbombo delle sue vittorie passate e delle generose istituzioni che la posero in grado di conseguirle. 


\subsection{A visão romântica da História}

O Romantismo, enquanto movimento renovador da cultura ocidental, possui um caráter plural. É por isso que podemos falar de literatura romântica, de poesia romântica, de teatro romântico, de pintura romântica, de escultura romântica, de filosofia romântica, de ciência romântica e de história romântica (muito embora em nossa opinião seja mais apropriado falar em visão romântica da História). Na base das ideias românticas, não por acaso surgidas na Europa na segunda metade do século XVIII em um cenário de profundas transformações econômicas, sociais e políticas criado pela Revolução Industrial e pela Revolução Francesa, estava a noção de Individualidade. O ser humano passa a ser concebido como um ente único, fruto de suas experiências e de seus conhecimentos. Essa ideia se expande para o coletivo, gerando povos e nações distintos uns dos outros pelo seu passado, e concedendo à História o poder de formatar identidades nacionais. Melhor dizendo, os povos não são mais reconhecidos somente como habitantes de uma determinada região, ou como súditos de uma casa real, mas como pessoas que compartilham a mesma língua, os mesmos hábitos e costumes, as mesmas práticas econômicas e principalmente a mesma herança cultural, ou seja, a mesma história. ${ }^{324}$

A partir do momento em que o Romantismo se opõe à visão clássica da universalidade do caráter do Homem, negando uma experiência histórica comum a toda a Humanidade (que era expressa no conceito de História como mestra da Vida), o Passado transforma-se em elemento crucial na construção da Cultura, em um processo que rejeitará as alegorias mitológicas em favor dos fatos históricos de cada nação. Como notou Mario Fubini, os românticos "à mitologia clássica e à qualquer outra mitologia opuseram, como fonte de uma poesia mais profunda e mais verdadeira, a História." 325 Como consequência desse novo ponto de vista, segundo Aldo Vallone, "a história rígida e iluminística cede lugar a uma percepção mais viva da Realidade e da Política. Surge então o interesse pelo país." ${ }^{326}$ Ou seja, pelo local e não mais pelos vastos impérios cuja história se desenrolava em vários

\footnotetext{
${ }^{324} \mathrm{Na}$ elaboração deste parágrafo muito devemos a dois estudos bastante sucintos e esclarecedores sobre o assunto aqui abordado: Nachman Falbel. "Fundamentos históricos do Romantismo" in J. Guinsburg (org). O Romantismo e Gilles Tiber. "O Romantismo e a Revolução Francesa" in Francis Claudon (org). Enciclopédia do Romantismo.

${ }^{325}$ Mario Fubini. "La polemica romantica (1947)" in Romanticismo italiano, saggi di storia della critica e della letteratura, p. 48 (nossa tradução)

${ }^{326}$ Aldo Vallone. Dal "Caffè" al "Conciliatore”, storia delle idee, p. 84 (nossa tradução)
} 
lugares não raro distantes e heterogêneos. É preciso ressaltar que a narrativa histórica de acontecimentos relativos aos impérios é uma história geral, já que o foco será o império como unidade e não suas diversas regiões ou províncias. Assim, a preocupação dos românticos com os costumes locais e com a formação dos povos em função da região que habitam gerou, na opinião de Carmelo Capuccio, "uma nova visão da História, não mais considerada uma extensa lista de erros, que uma vez repudiados permitiria finalmente a construção de uma época iluminada pela razão", porém um processo contínuo dentro do qual se desenvolvem em ritmo incessante "as conquistas e os sonhos das épocas mais distantes." ${ }^{227}$ Para Carlo Salinari, num contexto mais amplo a nova sensibilidade romântica formou-se através da "descoberta do valor e da dimensão do Sentimento no plano psicológico; do Povo no plano sociológico; da Nação no plano político; e da História no plano filosófico." ${ }^{328} \mathrm{Na}$ época romântica, de acordo com Aldo Vallone, "a História é elevada à significação de 'religião'. Ela se torna, fora dos círculos eruditos, a expressão das crenças, dos heroísmos e do sofrimento humanos." 329 Essa é a grande transformação ocorrida entre o Setecentos e o Oitocentos, a passagem do Classicismo ao Romantismo: surge uma preocupação em humanizar a História, em conectar o Passado e o Presente através de atos e não de fatos, em estudar mais as instituições do que os acontecimentos. Aparece o entendimento de que o Homem é o construtor do seu destino sobre a Terra, e que a História é a narrativa desse processo. Como porta-voz do movimento romântico que tentava se afirmar na Itália no período entre o Congresso de Viena e a irrupção das revoluções liberais, nosso periódico difundiu, em vários de seus artigos, uma teoria renovadora sobre o passado italiano. No parecer de Giorgio Candeloro, "ao seguir o esquema historiográfico das principais correntes românticas europeias os homens de II Conciliatore buscam na Idade Média as origens e o primeiro desenvolvimento da nação italiana, colocando, ou recolocando, em segundo plano a velha ideia, de origem humanística, de uma continuidade nacional-cultural entre a antiguidade

\footnotetext{
${ }^{327}$ Carmelo Capuccio. Storia della letteratura italiana, p. 486 (nossa tradução)

${ }^{328}$ Carlo Salinari. Storia popolare della letteratura italiana, volume III, Dalla seconda metà del Settecento al Novecento, p. 92 (nossa tradução)

${ }^{329}$ Aldo Vallone. Op cit, p. 61
} 
romana e a Itália medieval e a moderna." ${ }^{330}$ Era a busca por uma nova história para um novo tempo.

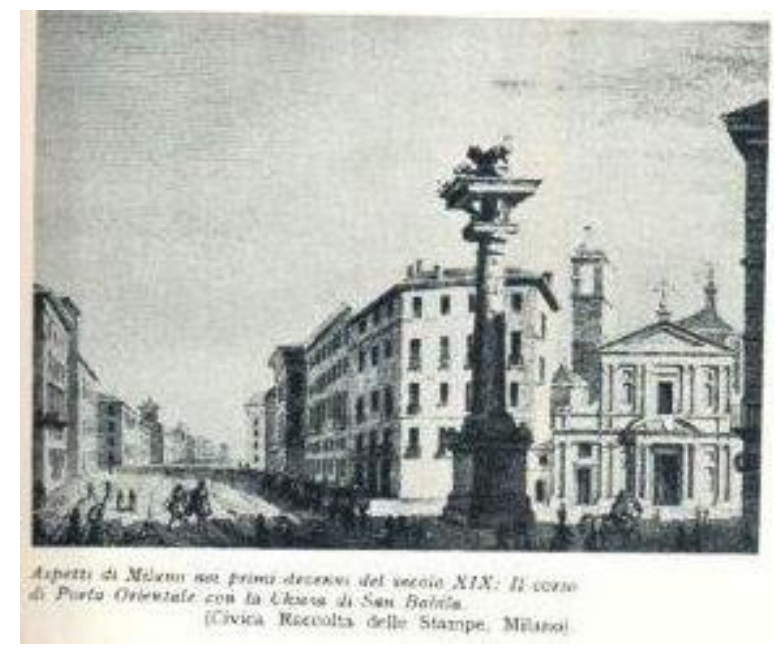

Vista de Milão nas primeiras décadas do século XIX: Rua da Porta Oriental e a Igreja de São Babila (in Cesare Spellanzon. Storia del Risorgimento e dell'unità d'Italia, p.618)

Todo período de transição caracteriza-se pela formulação de propostas inovadoras que expressam o descontentamento com o estado das coisas no campo teórico que se pretende modificar. São ideias que se mostram, não raro, inexequíveis mas que apontam as tendências que serão seguidas adiante, na marcha dos tempos. O problema básico da inovação, em qualquer disciplina ou atividade, são os meios disponíveis para realizá-la. É então que aparecem os limites, os obstáculos e as dificuldades a serem superados. Porém no início do processo, quando os desafios são mais teóricos do que práticos, o espaço reservado à Criatividade é mais amplo. Esse é o caso das resenhas sobre livros de história que aparecem em II Conciliatore, com suas propostas e ideias. Aqui, como no caso das obras dramáticas, da poesia e do romance, a discussão não era com os grandes historiadores do passado como Heródoto, Tácito, Políbio ou Tito Lívio; muito menos os renascentistas Maquiavel, Valla ou Guicciardini mas com os coevos que tentavam imitá-los escrevendo uma narrativa anacrônica, sem profundidade, na maioria das vezes, confusa e inexata. Federico Confalonieri, colaborador de nosso jornal, comenta que não consegue compreender "como se escreve a história sem

\footnotetext{
${ }^{330}$ Giorgio Candeloro. Storia dell'Italia moderna, volume II, Dalla restaurazione alla rivoluzione nazionale (1815-1846), p. 37 (nossa tradução)
} 
citar as autoridades, se contam os fatos sem indicar as fontes. Mas é desta maneira que muitíssimos descrevem a vida dos grandes homens e também dos impérios, dos governos e das nações. De minha parte sempre rejeitei com desprezo tais livros de histórias que em nada se distinguem das fábulas." ${ }^{331}$ Pode-se então notar que a primeira preocupação dos articulistas de nosso periódico era com a escrita da História.

$\mathrm{Na}$ visão romântica a narrativa histórica não deveria ser uma sucessão cronológica de acontecimentos. Ettore Li Gotti entende que "a História, para os nossos românticos, possui um valor moral; ela é mestra de vida e oferece portanto ao Poeta assuntos belíssimos." 332 Mas coloca-se então um limite que não estava tão claro na historiografia romântica produzida fora da Itália: a ideia classicista do caráter moralizador da experiência histórica. Muito embora essa preocupação possa ser explicada pelo desejo de assentar as bases do Ressurgimento, ela acaba por impor escolhas que aproximam as concepções classicistas e românticas dificultando, pelo menos no período aqui analisado, uma distinção nítida entre as duas escolas. Silvio Pellico, editor responsável por II Conciliatore, comentando sobre a ascensão e queda da República de Veneza, diz

Quando um grande edifício, a que ninguém teria feito algum reparo, vai ao chão ele torna-se um objeto interessante e útil para a reflexão do porquê os mortais o ergueram, com quais artifícios, através de quantos esforços, enfrentando quais perigos, entre quais aplausos, glórias, desgraças, delitos e virtudes. Todas as concepções do vasto engenho humano impressionam a nossa fantasia, todos os acontecimentos concernentes à história da espécie humana nos convocam insistentemente a refletir sobre nós mesmos e a buscar normas de conduta para nós e nossos filhos. ${ }^{333}$

Nota-se nesse trecho uma preocupação com a investigação dos motivos que levaram ao desfecho narrado, e não apenas à descrição dos fatos, porque é investigando as razões que se pode aprender com os erros e acertos do Passado.

\footnotetext{
331 "Icomprensibile è per me come si scriva la storia senza allegare le autorità, si raccontino i fatti senza indicare le fonti. Eppure cosi da moltissimi fannosi le vite degli uomini e degl'imperi, dei governi e delle nazioni." Federico Confalonieri. "Le citazioni" in II Conciliatore, num 43 (28/01/1819), p. 171 (nossa tradução)

${ }^{332}$ Ettore Li Gotti. G. Berchet - La letteratura e la politica del Risorgimento nazionale (17831851), p. 126 (nossa tradução)

333 "Ma quando un grande edifizio a cui niuno avrebbe voluto porre riparo giace finalmente a terra, allora nondimeno diventa oggetto interessante ed utile di meditazione il ricordare perché i mortali l'avessero eretto, con quali arti, con quali fatiche, fra quanti pericoli, fra quanti applausi, e gloria, e sciagure, e delitti, e virtù. Tutte le concezioni vaste dell'ingegno umano percuotono la nostra fantasia; tutti gli accidenti ragguardevoli della storia della umana specie ci chiamano potentemente a riflettere sovra noi medisimi, a cercar norme di condotta per noi e pei figli nostri." Silvio Pellico. "Histoire de la République de Venise. Par P. Daru - Sept volumes. Paris, 1819." Num 102 (22/08/1819), p. 411 (nossa tradução)
} 
Para que isso seja possível o historiador romântico não deveria se ater aos feitos dos grandes personagens históricos, mas às circunstâncias que possibilitaram seus atos.

Gian Domenico Romagnosi, assíduo investigador das páginas de II Conciliatore, ao analisar um compêndio sobre os grandes deslocamentos populacionais ocorridos na Antiguidade, com destaque para aqueles acontecidos no final do Império Romano (as invasões dos povos germânicos) opina que a obra em questão "apresenta os fatos com muita precisão e de uma forma interessante. $A$ História, considerada sob este ponto de vista, necessita não apenas da indicação dos acontecimentos como também das suas razões e de um exame dos seus resultados." Dessa maneira a narrativa histórica fica muito mais viva e próxima dos leitores, aumentando o interesse do público. Romagnosi considera que "a filosofia da história deve aplicar-se principalmente às grandes catástrofes que modificaram a face dos impérios", pois as reflexões sobre o comportamento errático dos antepassados pode ensinar os coevos a evitar o cometimento dos mesmos desatinos. Por isso, segundo o articulista, "depois da história primitiva deve apresentar-se a história filosófica, senão a memória dos fatos não pode transformarse em mestra de moral e de política, permanecendo apenas como uma curiosidade estéril." 334 O que aprendemos aqui é que dentro da visão romântica, o historiador não deve ser um mero cronista dos tempos pretéritos, mas um pensador capaz de analisar os acontecimentos do Passado para daí tirar lições úteis tanto para os indivíduos (moral) como para as instituições (política). Ou seja, não basta conhecer o Passado mas ser capaz de refletir sobre ele. Ettore Li Gotti diz que, nos anos de II Conciliatore, "na Itália a ideia de progresso, libertando-se pouco a pouco do seu velho invólucro, transformava-se no conceito de história. (...) já não se falava mais das belezas naturais e começava-se a discorrer sobre os sentimentos e sobre as paixões; sobre o Homem e sobre a sua história." ${ }^{335}$ Tudo isso era consequência da

\footnotetext{
334 "Quest' opera presenta gli avvenimenti con molta esattezza e in una maniera interessante. La storia, considerata sotto questo punto di vista, avrebbe però richiesto non solo l'indicazione dei fatti, ma l'esposizione delle loro cagioni e l'esame dei loro risultati. La filosofia della storia dee principalmente applicarsi alle grandi catastrofi che hanno cangiato la faccia degl'imperi. Dopo la storia primitiva deve comparire la storia filosofica, altrimenti la memoria dei fatti non può divenir maestra di morale e di politica, ma rimarrà solo alimento di una sterile curiosità" Gian Domenico Romagnosi. "Compendio storico della grande emigrazione dei popoli barbari, e delle emigrazioni principali accadute nell'antico mondo dopo quest'epoca (di L.C.D.B.) - volume in $8^{\circ}$, Brusselles. P. J. Demat stampatore della Accademia, 1818." Num 8 (27/09/1818), p. 32 (nossa tradução)

${ }^{335}$ Ettore Li Gotti. Op cit, p. 80
} 
nova sensibilidade, dos novos interesses que ganhavam espaço, de forma lenta porém inexorável, no cenário ideológico das primeiras décadas do Oitocentos. Cada vez mais os estudos se voltavam para a obra do Homem (a História) e deixavam de lado a obra de Deus (a Natureza).

Os estudos históricos passam a servir como fonte de inspiração poética. Em um artigo publicado em 1825 Giuseppe Montani, comentando as ponderações de Vicenzo Monti sobre o uso da Mitologia na produção literária italiana, notou

os modernos, tomando os seus assuntos da História, ou criando suas ficções com base na História, podem descrever todas as modificações, revelar-nos todos os segredos. Não creio que seja necessário que eu explique o amplo sentido que aqui dou à palavra História, já que me refiro não apenas aos fatos a nós transmitidos pela história propriamente dita mas também à infinita variedade daquilo que compõe a vida interior dos homens, assim como seu espírito. É dessa variedade infinita que a Poesia retira tanta riqueza, coisa que jamais foi possível aos antigos tentar fazer. ${ }^{336}$

É precisamente esse alargamento da visão histórica, a englobar também a maneira de pensar e agir dos antepassados, que irá distinguir classicistas e românticos, já que todos concordavam que a História era uma compilação de ensinamentos morais e políticos. Ettore Li Gotti acrescenta que para os fautores do Romantismo, ao menos na Itália, a História não poderia mais ser vista como "uma sucessão empírica e arbitrária de fatos" e muito menos ser tratada como uma cronografia. Era bem mais do que isso, era, segundo o crítico, "um meio de despertar no ânimo do Poeta contrastes de paixão, de sentimentos e de vontade; algo que vive para sempre dentro daqueles que são capazes de entendê-la: é a manifestação progressiva da ideia moral e religiosa." 337 Existe aqui uma concepção que começava a ganhar corpo e se manifestaria com maior vigor nos anos 1820 (não por acaso a década das revoluções liberais, dos pronunciamentos e dos levantes militares) seja na Europa ou nas Américas: todo povo decaído, escravizado e dominado por outro em algum momento de seu progresso histórico acabaria por rebelar-se e construir suas próprias instituições tornando-se uma nação soberana; todo império, por mais longevo e poderoso que seja, um dia seria vencido e

\footnotetext{
336 "I moderni, prendendone l'espressione dalla Storia, o fondando sulla Storia le loro finzioni, possono dipingere tutte le modificazioni, rivelarcene tutti i segreti. Non credo che sia necessario ch'io spieghi qual senso ampio do qui alla parola Storia, intendendo ognuno che sotto di essa io comprendo i fatti tramandatici dalla storia propriamente detta, come l'infinita varietà di quelli che compongono la vita interiore degli uomini, e quella del loro spirito. Dalla qualle infinita varietà viene alla Poesia tanta ricchezza, che mai gli antichi non avrebbero potuto provederla." Giuseppe Montani. "Intorno ao sermone 'Sulla Mitologia' di V. Monti (Antologia, ottobre 1825)" in Discussioni e Polemiche sul Romanticismo (1816-1826), volume 2, p. 285 (nossa tradução)

${ }^{337}$ Ettore Li Gotti. Op cit, p. 128
} 
destruído, como o foram o Império Persa, o Império Romano e o Império Napoleônico. Não é preciso explicar quais implicações políticas essa ideia gerou em solo peninsular, basta recordar os acontecimentos de 1821, quando na esteira da revolução liberal ocorrida em Portugal houve o levante da população milanesa contra a ocupação austríaca.

Os classicistas viam com reservas essa tentativa de substituir a Mitologia pela História nos enredos poéticos. Paride Zaiotti perguntava: "Mas quem conhece a história italiana? Será mais fácil encontrar cinquenta crianças que enumerem os reis e os imperadores de Roma do que achar uma que seja que conheça, por exemplo, a invasão de Carlos VIII à Itália (...)". ${ }^{338}$ Para os românticos a culpa por essa ignorância cabia aos historiadores, que segundo Pietro Borsieri eram "escritores obscuros, desprovidos de filosofia na mente e de elevação no coração." Aqueles que haviam se dedicado, nos séculos precedentes, à escrita da História mostraramse incapazes de elaborar um texto coerente: "Nos seus pesados volumes, felizmente não mais lidos pela maioria, eles encerraram, como em um sepulcro, a vida moral dos italianos ilustres." 339 Por isso a história da Itália estava muito mal feita, principalmente por que tentava-se, a todo custo, imitar Tácito ou Maquiavel ao invés de indicar documentos e testemunhos que validassem aquilo que estava sendo dito. Federico Confalonieri afirma que, entre os classicistas, "o historiador que cita suas fontes acredita estar diminuindo sua própria glória, revelando-se um repetidor, como se ele devesse ser um adivinho. Não existe quem ache que Lívio e Tácito tiraram da cabeça a história de Roma, e nem por isso Ihes são negados os mais sublimes elogios. Justamente por que se exige do historiador instrução verdadeira e prazer de leitura, deseja-se que os fatos narrados sejam providos de toda a autenticidade." 340 Para que a História exerça a função de mestra da Vida e de guia formador para

\footnotetext{
338 "Ma chi conosce la storia italiana? Sarà piú facile trovar cinquanta fanciulli che vi annoverino i re e gl'imperatori di Roma, che rinvenirne uno solo che conosca, per esempio, la discesa di Carlo VIII in Italia (....)." Paride Zaiotti. "Critica del sermone di Giovanni Torti 'Sulla Poesia' e delle 'idee elementari sulla poesia romantica' di Ermes Visconti (Biblioteca italiana, $1^{\circ}$ trimestre de 1819)" in Discussioni e Polemiche sul Romanticismo (1816-1826), volume 2, p. 18 (nossa tradução)

339 "(...) oscuri scrittori, i qualli, sprovvisti di filosofia nella mente e d'elevatezza nel cuore, si costituirono di loro propria autorità interpreti del genio (...). Ne' loro pesanti volumi, fortunatamente non leggibili dai più, chiusero costoro, come in proprio sepolcro, la vita morale degli illustri italiani." Pietro Borsieri. "Notizie sullo storico Giovanni Muller". Num 73 (13/05/1819), p. 293 (nossa tradução)

340 " (...) lo storico che cita, crede scemare la propria gloria, scoprendosi per ripetitore, quasichè esser dovesse un indovino. Non v'è però chi opini che Livio e Tacito traessero la storia di Roma dal loro cervello, e non per questo si nega loro la lode di sommi ingegni. Appunto perché si esige dallo storico vera istruzione e diletto, vuolsi che i fatti sien muniti di tutta l'autenticità." Federico Confalonieri. Op cit, p. 171
} 
os povos é necessário que a sua narrativa seja verdadeira, ou seja, estribada em fontes confiáveis. Isso modifica o papel desempenhado pelo historiador, pois ele, para os românticos, deve saber discriminar através de uma análise rigorosa as informações que embasam a sua narrativa, do contrário essa não será História, porém Fábula.

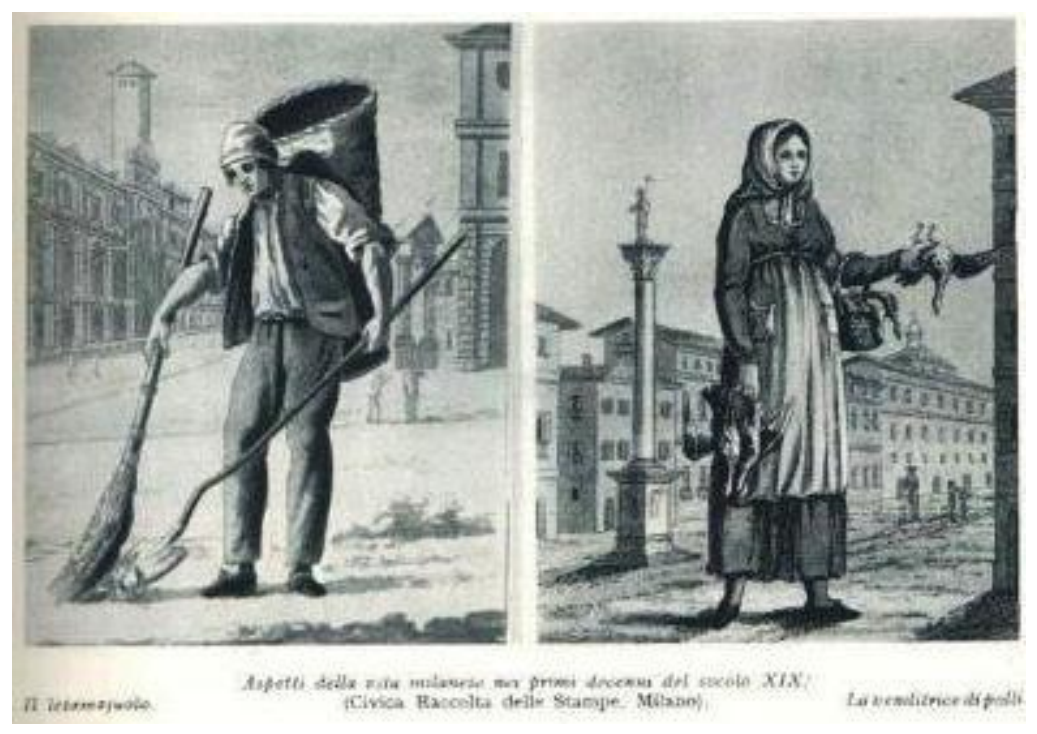

Cenas da vida milanesa nas primeiras décadas do século XIX: o lixeiro, a vendedora de frangos (in Cesare Spellanzon. Storia del Risorgimento e dell'unità d'Italia, p.623)

A diferença mais relevante entre a visão classicista e a visão romântica da História é a noção de progresso, ou seja, a Humanidade passa por um processo civilizatório composto por etapas sucessivas de construção da Cultura e a narrativa histórica é o registro desse percurso. A teoria dos ciclos históricos, presente nas obras de Políbio e Maquiavel, ganhou uma configuração mais profunda e instigante com o pensador italiano Gimbattista Vico. Em seu livro A Ciência Nova, lançado postumamente em 1744, o filósofo napolitano criou uma história ideal eterna pela qual passariam todos os povos e nações. ${ }^{341}$ Para Vico existe um curso histórico, determinado pela Providência Divina, composto obrigatoriamente por três épocas: a idade dos deuses, a idade dos heróis e a idade dos homens. Para cada uma dessas idades há uma organização social, política, cultural e econômica distinta e o objetivo de cada uma dessas etapas é atingir um grau mais elevado de civilização, assim um

\footnotetext{
${ }^{341}$ Para uma abordagem mais aprofundada deste tema consultar nossa dissertação de mestrado $\mathbf{A}$ Concepção de História em Giambattista Vico (FFLCH - USP, 2010)
} 
povo só consegue passar para outra etapa do seu curso histórico quando alcança o ponto máximo de desenvolvimento possível ao estágio no qual ele se encontra: daí a ideia de Progresso. ${ }^{342}$ Mas essa teoria era totalmente contrária à visão clássica da História, que considerava os homens iguais em todos os tempos e por isso propensos a cometer no Presente os mesmos erros do Passado. Desta forma, o aprendizado da História possuiria um caráter profilático, imunizando as sociedades contra uma série de desatinos e prevenindo desastres já ocorridos. Giuseppe Antonio Borgese, em sua história do pensamento romântico na Itália, comenta "na verdade, não há nada mais distante da alma do Classicismo do que a ideia de progresso e das pequenas causas da História: os historiadores do Classicismo são Tácito e Maquiavel. Por outro lado, todo o Romantismo foi viquiano, e criou - com ou sem a ideia de Providência Divina - na Alemanha, a filosofia da mutação; na França, a história do progresso; na Inglaterra, a ciência da evolução. Tratava-se sempre da oposição à maneira da Revolução Francesa: a Humanidade progride, mas não por obra dos tribunos e dos marechais." 343 Porém no movimento romântico italiano em geral, e no grupo de intelectuais reunidos em II Conciliatore, em particular, as concepções de Vico encontravam obstáculos para seu pleno fluir na impossibilidade de uma negação peremptória da herança clássica. Muitas das teorias que embasavam o classicismo europeu haviam sido elaboradas na Itália ao longo do século XVI; grande parte do patrimônio artístico que servia de paradigma para a arte clássica encontrava-se em solo italiano: eram ruínas arquitetônicas, como o Coliseu em Roma, e várias obras de procedência grega e romana que se espalhavam pela Península; havia também o legado dos grandes mestres da Renascença: Michelangelo, Leonardo, Brunelleschi e outros. Tudo isso tornava difícil uma ruptura radical nos moldes da que fora efetivada pelos pré-românticos alemães do Sturm und Drang e posicionava o romantismo italiano como um movimento renovador, que buscava colocar a cultura italiana em sintonia com as novas formas de pensamento que dominavam o debate intelectual na Europa pós-napoleônica. Carlo Calcaterra coloca esse problema ao dizer que "nossos primeiros românticos tinham reaberto A Ciência Nova de Vico e tinham intuído que, ao indagar sobre a formação da Poesia e sobre o desenvolvimento da história ideal humana aquele

\footnotetext{
${ }^{342}$ Giambattista Vico. Principi di Scienza Nuova d'intorno alle comune natura delle nazioni; §22, idea dell'opera.

${ }^{343}$ G. A. Borgese. Storia della critica romantica in Italia, p. 252 (nossa tradução)
} 
filósofo havia visto mais fundo do que todos aqueles que até então haviam escrito sobre esse assunto. Mas, vinculados como estavam a muitas ideias iluministas, que eram de domínio geral, não acharam uma maneira de resolver todo o seu pensamento em sentido viquiano." 344 Contudo, muito embora o nome de Vico nunca seja citado, é sua concepção de história enquanto progresso civilizatório guiado pela Providência Divina que domina as análises de cunho historiográfico que aparecem nas páginas de II Conciliatore.

Um exemplo da influência exercida por Giambattista Vico sobre as análises críticas de nosso periódico pode ser colhido na opinião de Gian Domenico Romagnosi em relação ao papel desempenhado pela Religião no processo civilizador dos povos. Segundo a teoria viquiana da história ideal eterna um povo só entra no curso das três idades após estabelecer três instituições: cultos religiosos, matrimônios solenes e cerimônias fúnebres. ${ }^{345}$ De fato, Vico identifica no temor a uma divindade superior o início da Civilização. Em seu artigo Romagnosi elenca sete razões pelas quais, no seu entendimento, "a Religião pode servir ao processo civilizador dos povos": 1ํ) Legitimar com sua autoridade as leis e as instituições criadas por um legislador. $2^{\circ}$ ) Infligir em seu nome as penas capitais, fazendo com que os réus sejam vítimas da ira divina. $3^{\circ}$ ) Impor o vínculo do juramento, ao ameaçar com sua vingança a quebra de pactos. $4^{\circ}$ ) Interferir nas deliberações públicas por meio de oráculos e previsões. 5ำ) Sancionar, mediante cerimônias de culto, as eleições da magistratura do Estado e os atos mais importantes da vida civil. 6ํ) Autorizar as declarações de guerra e através de sua bênção inspirar nos exércitos a fé, a coragem e o dever. $7^{\circ}$ ) Confirmar com sua autoridade os pactos e as condições de paz, assim como as convenções entre os povos. ${ }^{346}$ Esta é uma visão nitidamente viquiana porque afirma que a justiça, as guerras, a paz e as instituições públicas são passíveis de influência religiosa já que são fruto da mente e do esforço dos homens. Essa ideia de História como narrativa do progresso dos povos é uma das marcas da visão romântica sobre esta disciplina, compatível com a

\section{Ciência Nova.}

\footnotetext{
${ }^{344}$ Carlo Calcaterra. "Introduzione" in I manifesti romantici del 1816 e gli scritti principali del "Conciliatore" sul Romanticismo, p. 31 (nossa tradução)

${ }^{345}$ Giambattista Vico. Op cit; §333, degli elementi.

${ }^{346}$ Gian Domenico Romagnosi. "Emenda di alcuni openioni ricevute su l'indole e gli uffici della religione presso gli antichi Romani - Intorno ad alcuni istituzioni fatte da Romolo, ed alla influenza della religione sull'incivilimento - Che Romolo non fu capo d'una turba di masnadieri." Num 22 (15/11/1818), p. 87 (nossa tradução)
} 
Em uma resenha de autoria não identificada, ${ }^{347}$ de uma obra de Adeodato Ressi, o articulista coloca

a afirmação de que o Mundo é sempre o mesmo e que os homens de todas as idades são semelhantes aplica-se, sem dúvida, de forma justa em algumas oportunidades. Mas é absurdo que se pretenda, com base nesse princípio, negar a possibilidade do aperfeiçoamento social. Como também seria um delírio afirmar que os homens já se encontram colocados no mais alto grau da escala civilizatória. Na verdade os séculos mais ilustres foram superados por séculos posteriores que não estiveram isentos de gravíssimos erros e desordens. ${ }^{348}$

É uma argumentação contra a visão classicista da perenidade da História, ou seja, que uma vez atingido determinado estágio de perfectibilidade tanto nas instituições políticas quanto nas obras de arte esta perfeição deveria ser eternamente replicada, para o bem-estar da Humanidade. Por isso é importante o estudo do Passado, para que se possa achar em qual momento ou sob quais circunstâncias determinada arte ou instituição chegou ao seu grau máximo, de maneira que essas condições pudessem ser recriadas. Gian Domenico Romagnosi também se opõe a essa visão quando analisa um estudo sobre as mudanças administrativas ocorridas no tempo dos césares e diz

se o estado civil e político do Império Romano no tempo de Diocleciano
fosse exatamente o mesmo daquele do tempo de Augusto seria possível
escolher uma época ou outra ao bel-prazer, como idênticas. Mas
estudando-se a história política e civil de Roma descobre-se que seu estado
jamais foi estacionário, porém sempre mutável e progressivo, seja para o
Bem, seja para o Mal. Portanto, jamais será possível determinar um estado
particular definido tanto durante o período republicano quanto no período
imperial, porque tal estado, definitivamente, nunca existiu. Seria ainda mais
estranho falar de um estado genérico. As ideias genéricas podem ser
filosóficas, mas não históricas. ${ }^{349}$

${ }^{347}$ Os artigos e resenhas publicados em II Conciliatore eram sempre assinados com iniciais ao final do texto, assim S. P. (Silvio Pellico), E. V. (Ermes Visconti), G. D. R. (Gian Domenico Romagnosi), L. D. B. (Ludovico di Breme), G. P. (Giuseppe Pecchio), B. (Pietro Borsieri). Porém algumas vezes as iniciais não puderam ser identificadas.

348 "La trita esclamazione che il mondo è sempre lo stesso, che gli uomini di tutte le età si rassomigliano si applica non v'ha dubbio alcune volte giustamente, ma assurda ella è ogni volta che con essa si pretende negare la possibilità del perfezionamento sociale. Come pure sarebbe delirio l'affermare che gli uomini si trovino già collocati nel più alto grado d'incivilimento. E infatti i secoli più illustri furono superati da secoli posteriori, e questi non furono esenti da gravissimi errori e disordini." A. (Arrivabene?). "Dall'Economia della specie umana, di Adeodato Ressi - vol. I e II, presso Bissoni di Pavia." Num 38 (10/01/1819), p. 151 (nossa tradução)

349 "Se lo stato civile e politico dell'Impero Romano fosse stato al tempo di Diocleziano esattamente lo stesso di quello dei tempi di Augusto, si avrebbe potuto scegliere l'una e l'altra epoca a piacere, come fra loro identiche; ma studiando la storia politica e civile di Roma si scuopre che lo stato suo non fu mai stazionario, ma sempre mobile e progressivo sia nel bene, sia nel male. Non sarà dunque mai possibile di determinare un dato stato particolare tanto sotto la repubblica, quanto sotto l'impero, perocchè intimamente non esistette mai. Strano sarebbe voler parlare d'uno stato generico. Le idee generiche possono essere filosofiche, ma non istoriche." Gian Domenico Romagnosi. "Des changemans - Dei cangiamenti eseguiti in tutte le parti dell'amministrazione dell'Impero Romano sotto i regni di Diocleziano, di Costantino, e dei loro successori fino a Giuliano; opèra coronata 
Também aqui podemos detectar um viés viquiano, porque a definição de diferentes épocas não está propriamente ligada aos fatos que nelas ocorreram, mas ao ambiente intelectual que caracteriza cada período histórico. ${ }^{350} \mathrm{Na}$ medida em que, através dos tempos, realizam-se novas descobertas que ampliam 0 conhecimento dos homens sobre si mesmos e sobre a natureza que os cerca, a inteligência humana cria diferentes modos de vida que vão modificando as estruturas sociais e tornando anacrônicas as práticas ligadas a um cenário de ideias pretérito: por esse motivo é inútil procurar generalidades ao longo da História, pois para os românticos, o processo histórico é uma eterna mobilização em direção ao que ainda não foi vivido.

Giuseppe Pecchio, ao comentar um livro sobre as guerras que os ingleses naquela época travavam na Índia, lamenta que a ambição que move os exércitos modernos seja tão diferente daquela que motivava os exércitos antigos. Segundo ele, "nas conquistas dos povos antigos se exibe um intento mais magnânimo, mais nobre, direi quase mais heroico do que nas conquistas dos povos modernos. $O$ Romano ambicionava o comando dos homens: desejava subjugar o Cantábrico indomável, vencer o Parto invencível, plantar as suas águias nas Colunas de Hércules. O Moderno procura apropriar-se de uma mina, da foz de um rio, de um ramo da indústria, de uma zona de pesca." ${ }^{351}$ Podemos identificar nessa análise um elemento definidor da sensibilidade romântica: a Nostalgia. Como os homens são um produto do momento histórico em que vivem (da mesma forma que as épocas históricas são construídas pelos homens) existe uma sensação difusa de que o Mundo já viveu tempos melhores, habitado por pessoas mais interessantes do que aquelas que nos são contemporâneas. Por outro lado essa sensação romântica também alimenta a esperança num futuro promissor, já que uma das premissas

dell'accademia delle Iscrizioni e Belle Lettere nel concorso del 1815, di G. Naudet professore di rettorica nel collegio reale di Enrico IV, mastro delle conferenze alla scuola normale - Tome due in $8^{\circ}$ - Parige." Num 74 (16/05/1819), p. 297 (nossa tradução)

${ }^{350}$ Para uma apreciação mais aprofundada deste tema consultar Benedetto Croce. II concetto moderno della Storia.

351 'Nelle conquiste de' popoli antichi si palesa un fine più magnanimo, più altiero, direi quasi più eroico che nelle conquiste de' popoli moderni. II romano ambiva il comando sopra gli uomini; voleva domare il cantabro indomito, vincere il parto invincibile, piantare le sue aquile alle colonne d'Ercole. II moderno tende a impadronirsi d'una miniera, della foce d'un fiume, di un ramo d'industria, d'una pescagione." Giuseppe Pecchio. "Voyage dans l'Inde Britannique, ec - Viaggio nell'India Britannica, che contiene lo stato atuale di quelle regioni, la storia della guerra degl'Inglese contro Holkar e Sciindiah, la storia di Sha-Aulum, imperatore del Mogol, e la discrizione dei costumi ed usi di quel paese, con osservazioni sulla possibilità di una invasione nell'India d'una potenza europea. Traduzione del testo inglese di William Thorn e John Macdonald Kinneir - 1818". Num 38 (10/01/1819), p. 149 (nossa tradução) 
básicas do curso histórico descrito por Giambattista Vico em seu livro A Ciência Nova era que uma civilização grandiosa sempre decairia e possibilitaria então a ascensão de outros povos. Por isso, ao contrário do que acreditavam os classicistas, quanto mais uma cultura aproxima-se de sua expressão perfeita, mais ela avizinha-se da sua decadência. Esse paradoxo viquiano encantou românticos de todas as nacionalidades.

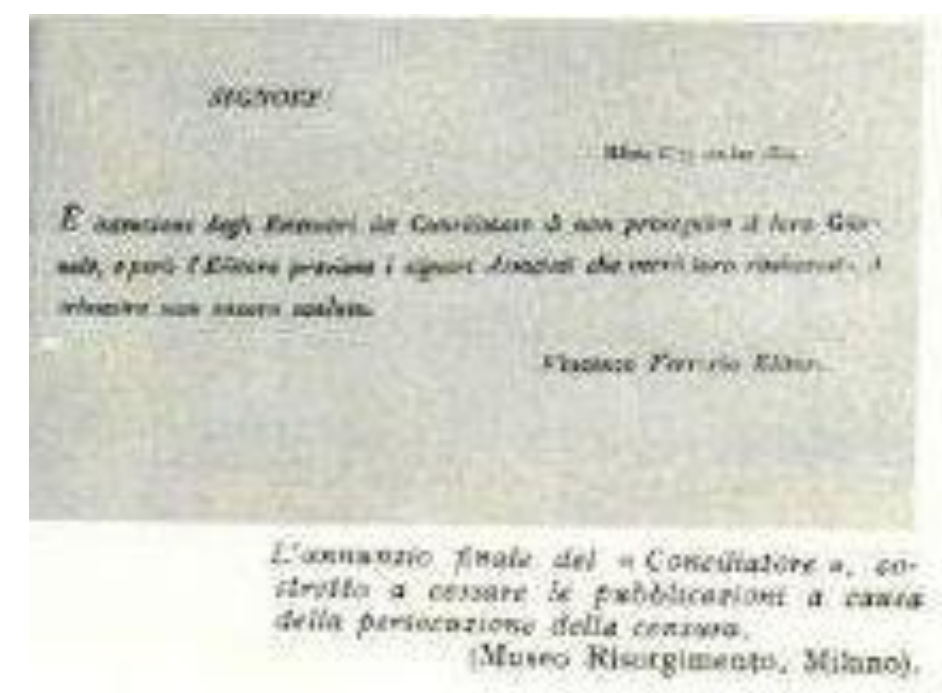

Anúncio aos assinantes do encerramento das atividades de Il Conciliatore devido às perseguições movidas pela censura da administração austríaca. (in Cesare Spellanzon. Storia del Risorgimento e dell'unità d'Italia, p. 774)

\title{
Pietro Borsieri em seu encômio ao historiador suíço Johann Muller, diz
}

\begin{abstract}
a Itália é a pátria da história moderna. Esta nasce conjuntamente com as florescentes cidades que formaram as repúblicas italianas na Idade Média, e que constituíram os centros mais ativos da segunda civilização da Europa, e pode-se dizer que foi primeiramente escrita sobre as tumbas dos romanos e entre as ruínas dos monumentos da Antiguidade. Villani, Maquiavel e Guicciardini (...) foram os primeiros a investigar a estrutura e a vida dos novos corpos políticos para depois referirem-se aos acontecimentos, tornando-se os precursores de todo grande historiador moderno. ${ }^{352}$
\end{abstract}

Isso implica reconhecer o legado da Renascença ao mesmo tempo em que diz que o medioevo italiano foi o responsável pelo renascer cultural da Europa. É

\footnotetext{
352 "L'Italia è come la patria della storia moderna. Nata questa insieme alle città sorgenti delle repubbliche del medio evo, le quali furono il centro più attivo della seconda civiltà dell'Europa, può dirsi che scrivesse le sue prime memorie sulle tombe de' romani, e tra i monumenti rovinosi dell'antichità. Villani, Macchiavelli, Guicciardini, perché riscossi dalla potente esperienza delle cose, scrutarono i primi la struttura e la vita de' nuovi corpi politici per poterne riferire gli avvenimenti; e furono i precursori d'ogni alto istorico moderno." Pietro Borsieri. "Notizie sullo storico Giovanni Muller." Num 70 (02/05/1819), p. 281 (nossa tradução)
} 
também um exemplo de como o grupo de II Conciliatore, apesar de suas inegáveis simpatias pelo Romantismo, procurava harmonizar interpretações discordantes, fazendo muitas vezes concessões a uma visão classicista da cultura italiana. Essa postura conciliadora limitou a compreensão da História num sentido mais nitidamente viquiano por que não viu a necessidade de uma ruptura radical com as instituições do Classicismo, bastando empenhar-se num discurso contra a fossilização da cultura promovida, em grande parte, pelas diversas academias literárias que abundavam em todas as cidades da Itália.

É possível extrair uma teoria da História das páginas de II Conciliatore? Não. Resenhas de livros e artigos de jornal, pela exiguidade do espaço, o caráter do público leitor e a necessidade de uma comunicação mais direta, não oferecem muitas oportunidades para um aprofundamento dos pontos de vista teóricos do articulista, e por isso são resenhas e não ensaios. Pode o pesquisador, no entanto, garimpar pepitas críticas nos diversos artigos que, ao longo de 118 números, trataram o tema. E aí encontramos uma preocupação sobre dois aspectos da disciplina em questão: a escrita da História e a noção de História como Progresso. São esses dois pontos que, em nossa opinião, identificam a abordagem romântica e proporcionaram uma leitura diferenciada, por parte do grupo de II Conciliatore, daquela que vinha sendo realizada na Itália até então.

A crítica fundamental feita pelos articulistas de II Conciliatore era a falta de credibilidade das narrativas históricas pelos imitadores de Tácito e de Tito Lívio já que estes recusavam-se a citar suas fontes afirmando que assim procederam os grandes historiadores da Antiguidade. Outra questão era o caráter cronográfico das obras. Mesmo compartilhando a ideia de que o estudo do Passado servia de guia para as ações do Presente, os românticos rejeitavam uma narrativa meramente descritiva dos feitos dos grandes personagens históricos em prol de uma análise do cenário político e cultural no qual essas figuras significativas atuaram, de forma a esclarecer os motivos de sua conduta. Ou seja, não bastava conhecer os erros e acertos dos antepassados era preciso entender por que eles haviam ocorrido.

Outro aspecto considerado pelos articulistas de nosso periódico foi a ideia da História como a narrativa de um processo civilizador dos povos. Essa visão foi 
influenciada pela concepção de história do filósofo Giambattista Vico. De acordo com ele todos os povos devem obrigatoriamente passar por três idades durante 0 seu processo de amadurecimento social, político e cultural: a idade dos deuses, a idade dos heróis e a idade dos homens. Ao atingir o apogeu civilizatório na idade dos homens, todos os povos decairão e iniciarão o ciclo novamente na idade dos deuses. Por que essa teoria ganhou consenso dentro e fora da Itália? Primeiramente porque negava a teoria classicista de uma era de perfeição que deveria eternizar-se pela imitação de seus modelos (aliás, muito pelo contrário, ela afirmava que o passo seguinte de tal civilização perfeita seria a sua decadência, acompanhada por sua ruína); depois por que promovia a ideia inversa, qual seja, um povo por mais decaído que estivesse ressurgiria com todo o vigor de sua cultura em algum momento do Futuro (o que proporcionava uma base teórica sólida para o Ressurgimento italiano); e finalmente libertava toda a criação artística de qualquer modelo que se tentasse impor-lhe (como os povos viviam diferentes épocas, a produção cultural da idade dos deuses não poderia ser reproduzida na idade dos homens, por exemplo). O que tudo isso nos mostra é que o debate sobre a historiografia italiana proposto por II Conciliatore foi crucial para a introdução de uma nova visão da História que prosperaria nas décadas seguintes. 


\section{[ $47^{5}$ ]}

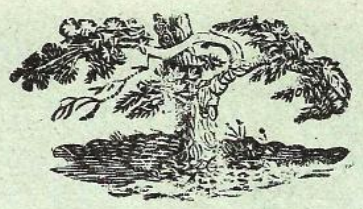

\section{NUMERO CXVIII.}

\author{
Prospetto generale della Storia Politica d'Europa \\ nel medio evo.
}

Articolo III (Vedi il Num. $8 \eta$ e 110.)

Secolo delle rivoluzioni.

Nel quindicesimo secolo tutti i popoli provarono tali rivoluzıoni, che ne risultò il presente stato d' Europa.

Nulla dirò della Scandinavia, dacchè la catastrofe di quella scena di turbolenze non poteasi prevedere. Nulla della Polonia; sebbene quelio fu il tempo della sua grandezza, ma l'Europa nol vide. Nulla della Russia; essa restò serva gran tempo.

Prima rivoluzione. Quando i Germani rovesciarono l'impero Romano, ciascuno di que' varj 16r capi conquistava per se stesso; ma a ciascun capo altresì toccò il debito di ricompensare suoi compagni d'arme; questi ebbero signorie. I re furono rispettati, quantunque non avessero altro potere fuor quello di presiedere all' assemblea nazionale. Tutti sanno quanto que're furouo deboli; von era possibile rispettarli come geuerali. e come tali unicamente avrebbero otteuuto il vero potere $(r)$. Ne venne che $\mathrm{i}$ grandi priucipi ebbero per ogni dove un potere immenso, nel mentre che $\mathrm{i}$ principi deboli non ne avevano alenso. Q qesto disordine apparente era l'ordine delle cose secondo le idee di que tenipi; ma gli autori giudicano il settimo secolo cui princijj del deeteroftavo: non si piezano mai a persua. der.i che nè $l^{\prime}$ antichità, nè il medio evo non
Rose. Alcuni capi di partito restarono ancora; ma Enrico VII non ignorava l'odio caduto su Luigi XI pei modi ch' ei tenne nel disfarsi di quelli di Francia. Invece d' incorrere la stessa taccia, li lasciò in vita; e tolse loro ogni credito, punendo sempre i malaccorti che s'affezionavano ad essi : cosi tulti li abbandonarono; e siccome le punizioni de' piccioli passano senża strepito. Luigi XI fu tenuto un Tiberio ed Enrico VII un Salomone. Per tal via, non meno dell'altro, egli giunse ad essere padrone in casa sua.

Luigi XI non avea spenti che signori; picciolo male era questo, a fronte di quanto in lspagna operavasi. I re di Spagua avevano a poco a poco cresciuto il loı potere. Ferdinando il cattolico e il suo ministro, voleudo far serva per sempre una nazione che da 800 anni combalteva per la sua libertà, fecero cosa inaudita per la quale non avvi che una espressione inaudita: uccisero lo spirito nazionale, e ne estinsero l'anima coll'inquisizione. Così il re di Spagna venne ad essere padrone in casa sua.

L'origine delle nostre monarchie fu la prima rivoluzione del secolo decimoquinto. Esse presero immantinente una prodigiosa preponderanza sa quegli stati, che per anco uon avevauo nè ceatro nè sistema.

Seconda rivoluzione. Fra i graudi che limitarnno la potenza dei re di Francia il duca di Borgogna era il solo temibile; però che gli stati af Filippo il buono, padrone de' Paesi-Bassi, duca di Borgogna, e conte della Franea Contea, fiorivano in grembo d'una lunga tranquillità, e sotto un governo paterno, più che mai non avese fiorito la Fiandra; e s' arricchivano e popolaransi mirabilmente. Nel tempo stesso la nobilta era auimata dal vero spirito della cavalleria, e ceotenuta dalla moderazione e dal potere del doct Usong re di Persia chiataavalo a ragione in gras 


\section{CONSIDERAÇÕES FINAIS}

O Romantismo representou uma troca nos paradigmas culturais do Ocidente. Ele foi uma resposta, no campo das letras e das artes, às transformações ocorridas na Política e na Economia em decorrência da Revolução Francesa e da Revolução Industrial. Foi uma revolta promovida por artistas e intelectuais contra o chamado Classicismo, ideal estético e artístico vigente desde a Renascença. As principais características românticas: a Subjetividade, a Individualidade, o Sentimento e o Particular refletiam o desejo de uma abordagem diferente da nova realidade sócioeconômica que se impunha com o surgimento da Burguesia e do Liberalismo. Em nossa opinião duas proposições românticas foram fundamentais para o estabelecimento de uma concepção cultural: o valor dado ao elemento local e a substituição da Mitologia pela História. Essas duas propostas estão intimamente ligadas porque a exaltação das raízes culturais da população autóctone baseava-se em uma pesquisa de seu passado, individualizando diversos povos através de suas características específicas. É por isso que acreditamos ser mais acertado falar em movimentos românticos do que propriamente em Romantismo.

O Classicismo operava dentro de três princípios: Ordem, Unidade e Universalidade. Os elementos constitutivos da obra de arte deveriam ser agregados de forma racional, obedecendo a um método consagrado pela Tradição, de forma a produzir um efeito estético universal e atemporal. O que deve aparecer diante do público é a Obra e não o Artista. O Romantismo irá romper essa visão contrapondo Loucura e Razão, Fantasia e Ordem, Particular e Universal. Ao exaltar as forças criativas que dominam 0 inconsciente do Gênio os românticos quebraram as correntes que segundo eles aprisionavam as artes em construções baseadas unicamente na Razão. A disposição dos elementos da obra de arte, para a estética romântica, deve ser uma expressão da originalidade de seu criador, ou seja, da fantasia individual de cada um. Na concepção romântica a criação artística está impregnada pelo ambiente e pelo momento histórico vividos pelo artista, que dá forma à sua sensibilidade para compreender (ou não) a realidade que o cerca. Portanto, o que deve aparecer diante do público é o Artista e não a Obra.

As mudanças propostas pelo Romantismo foram possíveis porque a Europa da segunda metade do século XVIII viveu o que ficou posteriormente conhecido como "dupla revolução", ou seja, a Revolução Industrial (econômica) e a Revolução 
Francesa (política). A esses movimentos renovadores somam-se a Revolução Americana, o Império Napoleônico e os processos independentistas das Américas espanhola e portuguesa que convulsionaram, junto com as chamadas revoluções liberais, os anos entre 1770 e 1830. O que gostaríamos de ressaltar dentro desse quadro histórico extremamente complexo no qual vicejaram as ideias românticas é a composição demográfica da Europa nesse período. Nunca antes tantos moços e moças tinham formado a população europeia. Os Anos Românticos foram povoados por jovens casais e suas crianças, beneficiados pela expansão urbana e pela ausência de grandes e devastadoras epidemias. Jovens anseiam por mudanças, são por natureza inquietos e possuem força física e entusiasmo para lutar por seus ideais. É por isso que o Romantismo valorizou a Juventude como a era da realização dos amores e dos sonhos.

Dentro desse panorama a Itália vivia uma situação peculiar. Politicamente fragmentada em diversos Estados e economicamente fragilizada no processo de expansão industrial devido à falta de recursos minerais a Península, em virtude de sua posição geográfica, tornou-se um campo de batalha entre as duas potências militares que surgiram após a Revolução Francesa: a França e a Áustria. Desde as décadas finais do século XVIII a ideia da reunificação italiana como a única via de acesso para um ressurgimento da antiga posição política e cultural desfrutada pelas cidades-estado do período renascentista ganhava força entre a elite dirigente italiana. Essa reunificação de certa forma ocorreu entre 1805 e 1815, quando Napoleão Bonaparte dividiu o território peninsular em dois reinos, o Reino da Itália e o Reino de Nápoles, ambos parte do Império Francês. Porém a derrota definitiva do imperador em Waterloo e a repartição territorial novamente imposta pelo Congresso de Viena convenceram os italianos que somente eles, e não uma potência estrangeira, poderiam reunificar a Itália. A situação política após 1815 converteu a Península em solo fértil para a semeadura das ideias liberais propostas pelo Romantismo.

Depois do Congresso de Viena o norte da Itália, com a exceção do Piemonte, foi unificado sob administração austríaca no Reino Lombardo-Vêneto, cuja capital era Milão. A efervescência intelectual da cidade tornou-a um polo de discussão sobre os novos rumos da cultura italiana. As concepções românticas importadas da Alemanha tiveram ali grande impacto nos debates sobre a decadência cultural da Itália. O argumento central do movimento romântico alemão para contrapor-se ao 
classicismo de matriz francesa tinha sido a recusa da Mitologia e da Antiguidade como paradigmas para a elaboração artística. A nova escola valorizava as tradições populares, os enredos históricos nacionais, a língua do povo em oposição ao latim dos letrados, e a Idade Média como fonte de inspiração para as novas criações poéticas e dramáticas. Além disso havia também a rejeição às regras de composição e às divisões estanques entre os gêneros artísticos. Os românticos sonhavam tragicomédias, arquiteturas sonoras, esculturas em movimento, poesias de cores e edifícios construídos nas nuvens. A principal objeção que os acadêmicos classicistas fizeram ao Romantismo é que este seria uma negação do passado histórico italiano, que estava ligado ao Império Romano do Ocidente. Mas para os românticos a Itália moderna e seu povo não descendiam dos antigos romanos e sim dos povos germânicos que os haviam conquistado. Segundo eles as raízes da cultura italiana estavam no período medieval de Dante e de Petrarca, e não na antiguidade clássica de Virgílio e de Ovídio.

Em 1818, com o intuito de divulgar as novas concepções estéticas que haviam surgido na Inglaterra e na Alemanha vinte anos antes, um grupo de intelectuais decidiu fundar um jornal de caráter literário e científico chamado II Conciliatore. Esse periódico, que circulava duas vezes por semana em Milão (às quintas-feiras e aos domingos) reuniu em suas páginas, entre outros, Silvio Pellico, Ermes Visconti, Giovanni Berchet, Pietro Borsieri e Ludovico di Breme. Esse grupo, que ficou conhecido como a primeira geração romântica italiana, participara ativamente da vida política e da administração do Reino da Itália. Alguns deles tiveram posição destacada na corte do vice-rei Eugênio Beauharnais, o sobrinho de Napoleão Bonaparte que governou em nome do imperador francês. Após perderem cargos e privilégios com a volta dos austríacos esses "filo-jacobinos" convenceramse que a única via política para a Península era a reunificação e a independência. Desde o seu início II Conciliatore foi atacado por aqueles italianos que não concordavam com suas ideias românticas e sofreu uma severa censura da parte do governo austríaco, que via no jornal um polo aglutinador de descontentes com a ocupação estrangeira.

As dificuldades impostas pela administração austríaca do Reino LombardoVêneto deram a essa primeira geração romântica italiana um caráter acentuadamente político, uma característica que não aparecera até então em outros movimentos românticos. O grupo de II Conciliatore recebeu uma forte influência do 
romantismo alemão, diferente do movimento romântico italiano da década de 1830 , de matriz francesa. A forte repressão no período da Restauração e a grande instabilidade política da década de 1820 , a era das revoluções liberais, fez com que as grandes obras do romantismo italiano aparecessem depois de 1830 , portanto fora do objeto de análise deste estudo.

E o que podemos inferir de I/ Conciliatore e de seu combate em prol do Romantismo na Itália? Em primeiro lugar seus articulistas apresentaram aos leitores obras e artistas até então pouco conhecidos: Schiller, Chernier, Byron, Camões, Calderón de La Barca, Shakespeare, os irmãos Schlegel, Sheridan e outros hoje sepultados pelo correr dos tempos. Porém na época isso representou uma abertura no debate cultural para novas temáticas e abordagens. Foi na verdade um primeiro contato com a então vanguarda europeia, uma inserção da Itália dentro dos novos paradigmas das letras e das artes. Muito embora isso tenha sido realizado de maneira esporádica ao longo da década de 1810, o aparecimento de II Conciliatore, em 1818, aglutinou os românticos em um polo difusor de suas ideias e ampliou, assim como radicalizou, o debate estético. Além disso o jornal mostrou aos italianos, de forma aberta e corajosa, a mediocridade da sua produção artística, aprisionada pelos dogmas das academias.

Em segundo lugar II Conciliatore procurou criar uma outra visão historiográfica. Bastante influenciados pelo pensamento do filósofo setecentista Giambattista Vico, os articulistas de nosso jornal colocaram-se contra a concepção clássica da História como mestra da Vida. Para eles a História não era um conjunto de fatos grandiosos cujo conhecimento possibilitava um aprimoramento moral e intelectual, mas a narrativa de ações humanas em diferentes épocas que ilustrava o desenvolvimento, ou no jargão da época, o Progresso da Humanidade. Os românticos do grupo de II Conciliatore combateram o uso da Mitologia nos argumentos literários dizendo que ela chocava-se com o entendimento do Mundo difundido pelo Cristianismo. Era a ideia de que o Classicismo, em termos teológicos, representava uma heresia e introduzia na Itália aquela religiosidade anti-iluminista que havia se desenvolvido de forma robusta entre as classes letradas na Alemanha nos lustros finais do século XVIII. Outro alvo do combate romântico foi a noção de que os italianos eram os herdeiros das obras produzidas na Antiguidade. II Conciliatore estabeleceu a teoria segundo a qual a Itália moderna fora gerada durante a Idade Média pelos povos germânicos que haviam conquistado o Império 
Romano do Ocidente. As raízes da cultura italiana estavam fincadas nas comunas medievais e no Cristianismo, e não em Roma e na sua religião individualista e sensual.

É fato que as ideias românticas de /l Conciliatore não puderam ser expostas em sua plenitude devido à censura ferrenha que Ihe foi imposta pelo governo austríaco: artigos eram mutilados, articulistas eram ameaçados e a distribuição do periódico era restrita a Milão e seus arredores. Toda essa pressão fez com que o jornal encerrasse suas atividades após pouco mais de um ano de circulação. Foram cento e dezoito números com artigos de Silvio Pellico, Giovanni Berchet, Pietro Borsieri, Ludovico di Breme, Gian Domenico Romagnosi, Giuseppe Pecchio, Ermes Visconti, Giuseppe Nicolini entre outros colaboradores eventuais. Um grupo de intelectuais coeso em suas ideias e com suficiente coragem para expor seus pontos de vista na tumultuada Itália do período da Restauração pós-napoleônica, no esplendor dos Anos Românticos.

Para encerrar gostaríamos de dizer que o Romantismo foi o credo extremista de uma era de extremos. Seus fautores foram pessoas para quem o Mundo se apresentava sem peias, num turbilhão a ser vivido da maneira mais intensa possível. Eles nos mostraram que podemos experimentar nossos limites e que arriscar a vida por um momento de prazer ou de realização individual não é somente uma atitude válida, mas até desejável. Eles expandiram as fronteiras do Sentir, do Criar e do Viver. É por isso que continuamos a admirar e a venerar os românticos tanto tempo depois de a época turbulenta e revolucionária que os gerou ter passado. 


\section{BIBLIOGRAFIA}

\section{Fontes}

II Conciliatore, Foglio Scientifico-Letterario (3 settembre 1818 - 17 ottobre 1819); Edizione Anastatica. Bologna: Arnaldo Fornì, 1981

I manifesti romantici del 1816 e gli scritti principali del Conciliatore sul Romanticismo; a cura di Carlo Calcaterra. Torino: UTET, 1951

Discussioni e Polemiche sul Romanticismo, 1816-1826; a cura di Egidio Bellorini; 2 volumi. Bari: Gius. Laterza e Figli, 1943

BERCHET, Giovanni. Sul Cacciatore Feroce e sulla Eleonora di Gofredo Augusto Bürger. Lettera Semiseria di Grisostomo al suo Figliuolo (Dezembro de 1816) in Carlo Calcaterra (org). I manifesti romantici del 1816. Torino: UTET, 1951

BORSIERI, Pietro. Avventure letterarie di un giorno o consiglio di un galantuomo a vari scrittori (setembro de 1816) in Carlo Calcaterra (org). I manifesti romantici del 1816. Torino: UTET, 1951

DI BREME, Ludovido Arborio Gattinara. Intorno all'ingiustizia di alcuni giudizi letterari italiani (junho de 1816) in Carlo Calcaterra (org). I manifesti romantici del 1816. Torino: UTET, 1951

GHERARDINI, Giovanni. Un italiano risponde al discorso della Staël (abril de 1816) in Egidio Bellorini (org). Discussioni e Polemiche sul Romanticismo, 1816-1826. Volume I. Bari: Gius. Laterza e Figli, 1943

MENZIO, Pier Angelo (org). Dal Conciliatore. Torino: UTET, 1927

STAËL, Madame de (Anna Luisa Staël-Holstein). Sulla maniera e l'utilità delle traduzioni (janeiro de 1816) in Egidio Bellorini (org). Discussioni e Polemiche sul Romanticismo, 1816-1826, volume I. Bari: Gius. Laterza e Figli, 1943

\section{Outras Obras}

ADORNO, Theodor e Benjamin, Walter. Os Pensadores, volume XLVIII. São Paulo: Abril Cultural, 1975

APPOLONIO, Carla. Romantico: storia e fortuna di una parola. Firenze: G. C. Sansoni Editore, 1958

BARBEY D'AUREVILLY, Jules. As Diabólicas. Rio de Janeiro: Editorial Bruguera, 1971

BELLORINI, Egidio. // Conciliatore e la censura austriaca in Scritti varii di erudizione e di critica in onore di Rodolfo Renier. Torino: Bocca, 1912 
BENJAMIN, Walter. O conceito de crítica de arte no Romantismo alemão; tradução, introdução e notas de Márcio Seligmann-Silva; São Paulo: lluminuras, 1999, $2^{a}$ edição

BERLIN, Isaiah. Vico e Herder. Brasília: Editora Universidade de Brasília, 1997 (4ª edição)

BOESCH, Bruno (org). História da Literatura Alemã. São Paulo: Editora Herder / Edusp, 1967

BOILEAU-DESPRÉAUX, Nicolas. A arte poética; introdução, tradução e notas de Célia Berretini. São Paulo: Editora Perspectiva, 1979

Boletim n. ${ }^{\circ} 20$ (nova série) Homenagem a Ugo Foscolo; Omaggio. São Paulo: Faculdade de Filosofia, Letras e Ciências Humanas da Universidade de São Paulo; Departamento de Letras Modernas, 1979

BONORA, Ettore. Storia della letteratura italiana; Torino: Petrini, 1977, $\left(2^{\mathrm{a}}\right.$ edizione)

BORGESE, G. A. Storia della critica romantica in Italia (con una nuova prefazione). Milano: Fratelli Trevis Editori, 1920

BOSCO, Umberto. Realismo romantico. Palermo: Salvatore Sciascia Editore, 1959 Aspetti del Romanticismo italiano. Roma: Edizione Cremonese, 1942

BOTTACHIARI, R. La rivoluzione romantica. Roma: Perrella, 1942

BOTTONI, L. Drammaturgia e sistemi letterari nel Conciliatore in LI, 1983

BRAGA, Gaetano Capone. La filosofia francese e italiana del Settecento. Padova: Cedam, 1942.

BURKE, Edmund. Reflexões sobre a Revolução em França. Brasília: Editora Universidade de Brasília; 1997 (2ª edição)

CANDELORO, Giorgio. Storia dell'Italia moderna, volume I, Le origini del Risorgimento, 1700-1815; Milano: Feltrinelli Editore, 1977, nona edizione; $\left(1^{\mathrm{a}} \mathrm{ed}\right.$, 1956)

Storia dell'Italia moderna, volume II, Dalla restaurazione alla rivoluzione nazionale, 1815-1846; Milano: Feltrinelli Editore, 1981, decima edizione; ( $1^{\text {a }}$ ed, 1958)

CAPUCCIO, Carmelo. Storia della letteratura italiana; Firenze: Sansoni, 1962 (4 edizione riveduta e aggiornata con appendice bibliografica).

CARLSON, Marvin. Teorias do Teatro: estudo histórico-crítico dos gregos à atualidade. São Paulo: Fundação Editora da UNESP, 1997 
CECCHI, Emilio e Sapegno, Natalino (org). Storia della letteratura italiana, volume VII, L'Ottocento. Milano: Garzanti, 1976 (1 ${ }^{\mathrm{a}}$ ed, 1969)

CÉSAR, Guilhermino (seleção e apresentação). Historiadores e Críticos do Romantismo, volume 1, A contribuição europeia: crítica e história literária. Rio de Janeiro: Livros Técnicos e Científicos / São Paulo: Edusp, 1978

CLAUDON, Francis (org). Enciclopédia do Romantismo. Lisboa: Verbo, s/d CLERICI, Edmundo. II Conciliatore, periodico milanese. Pisa: Nistri, 1903

CLERY, E. J. The Rise of Supernatural Fiction: 1762-1800. Cambridge:

Cambridge University Press, 1999 (paperback edition)

CANTÙ, Cesare. II Conciliatore e i carbonari. Milano: 1878

CROCE, Benedetto. II concetto moderno della Storia. Bari: Gius. Laterza e Figli, 1947

. Le definizioni del romanticismo in Problemi di estetica. Bari: Laterza, 1910

D'ADDEO, R. II pubblico del Conciliatore in Misure critiche, 1978

DE COURTEN, Clementina. Milano romantica e la Francia della restaurazione. Milano: Edizioni Alpes, 1925

DE SANCTIS, Francesco. La letteratura italiana nel secolo decimonono, volume terzo. Napoli: Alberto Morano Editore, 1930

DUARTE, Rodrigo Antonio de Paiva. Adorno / Horkheimer e a dialética do esclarecimento. Rio de Janeiro: Jorge Zahar Editor, 2004 ( $2^{\mathrm{a}}$ edição)

DUVIGNAUD, Jean. Sociologia do Comediante. Rio de Janeiro: Zahar Editores, 1972

Enciclopedia Italiana di Scienze, Lettere ed Arti; Roma: Istituto della Enciclopedia, 1929-1937; 35 volumi

FARINELLI, Arturo. II romanticismo nel mondo latino. Torino: Fratelli Bocca, 1927 (3 volumes)

FIORAVANTI, G. Melli. Immagini e ruolo del litterato romantico nel Conciliatore in RLI, 1978

FLORA, Francesco. Storia della letteratura italiana, volume III, parte I, L'Ottocento. Milano: Mondadori, 1950

FUBINI, Mario. Romanticismo italiano: saggi di storia della critica e della letteratura. Bari: Laterza, 1953 
e Bonora, Ettore (org). Antologia della critica letteraria, volume 3, Dall'Arcadia agli inizi del Novecento Torino: G. B. Petrini, 1960; (sesta edizione aumentata); (1 ${ }^{\mathrm{a}}$ ed, 1954)

GALLETTI, Alfredo. Le origini del romanticismo italiano e l'opera di Alessandro Manzoni. Milano: Montuoro Editore, 1942

GASSNER, John. Mestres do Teatro. São Paulo: Editora Perspectiva / Edusp. 1974 (2 volumes)

GAY, Peter. A experiência burguesa da Rainha Vitória a Freud, volume 1, A educação dos sentidos. São Paulo: Companhia das Letras, 1988

GOETHE, Johann Wolfgang von. Memórias: Poesia e Verdade (2 volumes).

Brasília: Editora da Universidade de Brasília/São Paulo: Hucitec, 1986 (2ª edição)

Viagem à Itália: 1786-1788. São Paulo: Companhia das Letras, 1999

GOTTI, Ettore Li. G. Berchet - la letteratura e la politica del risorgimento nazionale (1783-1851). Firenze: La nuova Italia Editrice, 1933

. La nascita del Conciliatore in Saggi. Firenze: La Nuova Italia, 1941

GUINSBURG, J. (org). O Romantismo. São Paulo: Editora Perspectiva / Secretaria da Cultura, Ciência e Tecnologia, 1978

O Classicismo. São Paulo: Editora Perspectiva, 1999

GUSTARELLI, Andrea. II Conciliatore. Milano: Treves, 1918

HEGEL, Georg Wilhelm Friedrich. Curso de Estética: O Sistema das Artes; tradução de Álvaro Ribeiro. São Paulo: Martins Fontes, 1997

Curso de Estética: O Belo na Arte; tradução de Orlando Vitorino e Álvaro

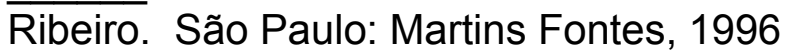

HEINE, Heinrich. Contribuição à História da Religião e Filosofia na Alemanha; tradução de Márcio Suzuki. São Paulo: Iluminuras, 1991

HENDERSON, William Otto. A Revolução Industrial: 1780-1914. São Paulo: Verbo/Edusp, 1979

HOBSBAWN, Eric J. A Era das Revoluções: Europa: 1789-1848. Rio de Janeiro: Paz e Terra, 1997 (10ª Edição)

HUGO, Victor. Do Grotesco e do Sublime; tradução e notas de Célia Berretini. São Paulo: Editora Perspectiva, s/d

KAYSER, Wolfgang. O Grotesco. São Paulo: Editora Perspectiva, 1986 
LOVECRAFT, Howard Phillips. O Horror Sobrenatural na Literatura. Rio de Janeiro: Livraria Francisco Alves Editora, 1987

MALATO, Enrico (org). Storia della Letteratura Italiana, volume VII, II Primo Ottocento. Roma: Salerno Editrice, 1998

MARCAZZAN, M. II tempo del Conciliatore in Storia di Milano, volume XVI. Milano: Mondadori, 1962

MUONI, Guido. Note per una poetica storica del romanticismo. Milano: Società Editrice Libraria, 1906

NOBRE, Marcos. A Teoria Crítica. Rio de Janeiro: Jorge Zahar Editor, 2004

ORTEGA Y GASSET, José. A ideia do Teatro. São Paulo: Editora Perspectiva; Secretaria da Cultura, Ciência e Tecnologia do Estado de São Paulo, 1978

OSBORNE, Harold. Estética e Teoria da Arte. São Paulo: Cultrix, 1978 (3ª Edição)

OLIVEIRA LIMA, Manuel de. Dom João VI no Brasil. Rio de Janeiro: Top Books, 1996 (3ª Edição)

PELLICO, Silvio. Lettere Milanesi (1815-1821). Torino: Loescher, 1963

. Epistolario. Torino: Tipografia e Libreria Salesiana, 1879 (quarta edizione)

PESENTI, Amilcare. II Romanticismo in Italia. Milano: Giacomo Agnelli, 1882

PETRINI, D. La poetica del Conciliatore e il Berchet in La Cultura, anno IX, volume I - Luglio, 1930

POLIBIUS. História; tradução de Mário da Gama Kury. Brasília: Editora Universidade de Brasília, 1996 ( $2^{\mathrm{a}}$ edição)

PRADO, Paulo. Retrato do Brasil: ensaio sobre a tristeza brasileira. São Paulo: Companhia das Letras, 1997

PRAZ, Mario. A carne, a morte e o diabo na literatura romântica. Campinas: Editora da Unicamp, 1996

ROMANO, Ruggiero e Vivanti, Corrado (org). Storia d'Italia, volume terzo, Dal primo Settecento all'Unità. Torino: Giulio Einaudi Editore, 1973

ROSSI, Paolo. Storia d'Italia dal 1500 al 1815. Milano: Mursia, 1971 Storia d'Italia dal 1815 al 1914. Milano: Mursia, 1972

ROSSI, Vittorio. Storia della letteratura italiana per uso dei licei, volume terzo, L'età moderna; Milano: Casa Editrice Dottor Francesco Villardi, 1928 
SALINARI, Carlo. Storia popolare della letteratura italiana, volume III, Dalla seconda metà del Settecento al Novecento; Roma: Editori Riuniti, 1962

SAPEGNO, Natalino. Disegno storico della letteratura italiana ad uso delle scuole medie superiore; ventottesima ristampa. Firenze: La Nuova Italia, $1972\left(1^{\text {a }}\right.$ ed, 1948)

SCHANZER, Alice. II Romanticismo in Italia. Perugia: Umbra, 1899

SCHILLER, Friedrich. A educação estética do homem numa série de cartas; tradução de Roberto Schwarz e Márcio Suzuki; introdução e notas de Márcio Suzuki; São Paulo: Iluminuras, 1995; (3ª edição)

SCHILLER, Friedrich. Poesia ingênua e sentimental; tradução, apresentação e notas de Márcio Suzuki. São Paulo: Iluminuras, 1991

SCHLEGEL, Friedrich. Conversa sobre a poesia e outros fragmentos; tradução, prefácio e notas de Victor-Pierre Stirnimann. São Paulo: Iluminuras, 1994

O Dialeto dos Fragmentos; tradução, apresentação e notas de Márcio

Suzuki. São Paulo: Iluminuras, 1997

SPELLANZON, Cesare. Storia del risorgimento e dell'unità d'Italia, volume primo, Dalle origini ai moti del 1820-21 e al congresso di Verona (prima ristampa nuovamente correta e accresciuta). Milano: Rizzoli, 1951 (1ª ed, 1933)

STENDHAL. Racine e Shakespeare in Johnson, Samuel. Prefácio a Shakespeare (seguido por Racine e Shakespeare por Stendhal); tradução, estudo e notas por Enid Abreu Dobránszky. São Paulo: Iluminuras, 1996

VALLONE, Aldo.Dal Caffe al Conciliatore: storia delle idee. Lucca: Casa Editrice Lucentia, 1953

. Il trapasso dall'iluminismo al romanticismo nel Conciliatore in Studi sul

Berchet. Pubblicati per il primo centenario della morte. Milano: Mondadori, 1951

VICO, Giambattista. Opere; a cura di Fausto Nicolini. Milano/Napoli: Riccardo Ricciardi Editore, 1953

WELLECK, René. A History of Modern Criticism: 1750-1950, volume 1, The Later Eighteenth Century. New Haven: Yale University Press, 1955

A History of Modern Criticism: 1750-1950, volume 2, The Romantic

Age. New Haven: Yale University Press, 1955 


\section{ÍNDICE DAS ILUSTRAÇÕES}

As figuras inseridas ao longo do texto têm por objetivo fornecer ao leitor uma informação visual sobre a época em que circulou II Conciliatore. São gravuras que demonstram a preocupação dos românticos em retratar a vida do povo nas ruas.

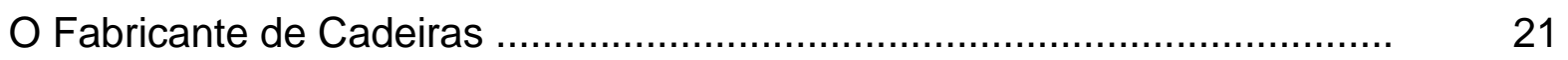

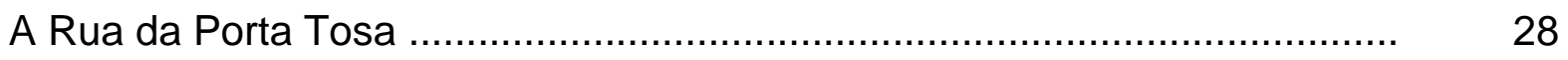

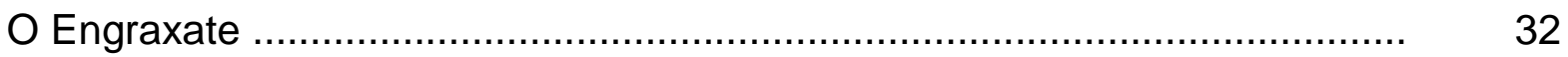

A Igreja de São Lourenço ....................................................................

A Vendedora de Telas ................................................................. 40

A Modista, o Cortador de Lenha ......................................................... 46

Retrato de Friedrich Schlegel............................................................... 57

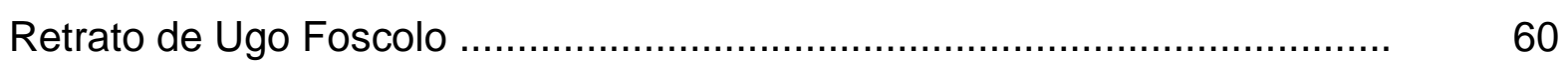

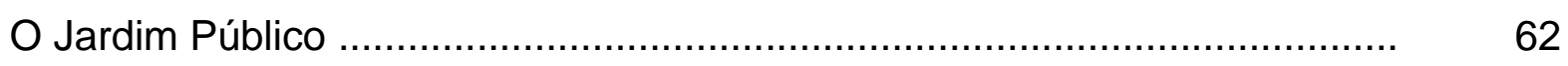

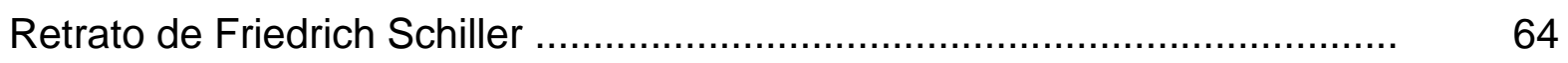

O Carregador, a Lavadeira ………................................................ 67

Página de Rosto de Il Conciliatore e i Carbonari, de Cesare Cantù .......... 73

Retrato de Silvio Pellico .........................................................................

Retrato de Giovanni Berchet ......................................................... 85

Retrato de Giovanni Carlo Sismondo Sismondi .......................................... 88

Retrato de Ermes Visconti ................................................................. 89

A Primeira Página do "Programma" de I/ Conciliatore ................................. 93

Retrato de Ludovido Arborio di Breme ....................................................... 97

Página de rosto de II Conciliatore, periodico milanese, de Edmondo Clerice .................................................................................. 105

O Entregador de Pães .................................................................... 117

Uma Página de L'accattabrighe .......................................................... 118

Piazza Fontana com o Palácio Arcebispal .................................................. 128

Casa Belloni na Rua da Porta Oriental ....................................................... 139

O Acendedor de Lâmpadas .................................................................... 142

A Rua de São Celso ……........................................................ 150

O Primeiro Número de I/ Conciliatore ….................................................... 153 
A Rua da Porta Oriental e a Igreja de São Babila ....................................... 156

O Lixeiro, a Vendedora de Frangos ....................................................... 161

Anúncio aos assinantes do encerramento das atividades de Il Conciliatore. 166

O último número de I/ Conciliatore 